\title{
ANÁLISE DE FATORES QUE INFLUEM NO USO DA BICICLETA PARA FINS DE PLANEJAMENTO CICLOVIÁRIO
}

\section{Pablo Brilhante de Sousa}

Tese apresentada à Escola de Engenharia de São Carlos da Universidade de São Paulo, como parte dos requisitos para obtenção do título de Doutor em Ciências na área de Planejamento e Operação de Sistemas de Transportes.

Orientador: Prof. Titular Eiji Kawamoto

São Carlos-SP, Brasil Agosto

2012 
AUTORIZO A REPRODUÇÃO E DIVULGAÇÃO TOTAL OU PARCIAL DESTE TRABALHO, POR QUALQUER MEIO CONVENCIONAL OU ELETRÔNICO, PARA FINS DE ESTUDO E PESQUISA, DESDE QUE CITADA A FONTE.

Ficha catalográfica preparada pela Seção de Tratamento da Informação do Serviço de Biblioteca - EESC/USP

$S 725 a$

Sousa, Pablo Brilhante de

Análise de fatores que influem no uso da bicicleta para fins de planejamento cicloviário. / Pablo Brilhante de Sousa ; orientador Eiji Kawamoto. -- São Carlos, 2012.

Tese (Doutorado - Programa de Pós-Graduação em Engenharia de Transportes e Área de Concentração em Planejamento e Operação de Sistemas de Transportes) -Escola de Engenharia de São Carlos da Universidade de São Paulo, 2012 .

1. Planejamento cicloviário. 2. Uso da bicicleta. 3. Modelos de escolha discreta. 4. Características socioeconômicas. 5. Infraestrutura cicloviária. 6. Ciclovias. 7. Ciclofaixas. I. Título. 
Candidato: Engenheiro PABLO BRILHANTE DE SOUSA.

Título da tese: "Análise de fatores que influem no uso da bicicleta e seu uso no planejamento cicloviário".

Data da defesa: 01/10/2012

\section{Comissão Julgadora:}

Prof. Titular Eiji Kawamoto (Orientador)

(Escola de Engenharia de São Carlos/EESC)

Prof. Associado Antônio Nelson Rodrigues da Silva

(Escola de Engenharia de São Carlos/EESC)

Profa. Dra ${ }^{\mathrm{a}}$. Suely da Penha Sanches

(Universidade Federal de São Carlos/UFSCar)

Prof. Dr. Marcus Vinicius Guerra Seráphico de Assis Carvalho

(Universidade Federal do Pará/UFPA)

Prof. Dr. Pastor Willy Gonzales Taco

(Universidade de Brasília/UnB)
Resultado:
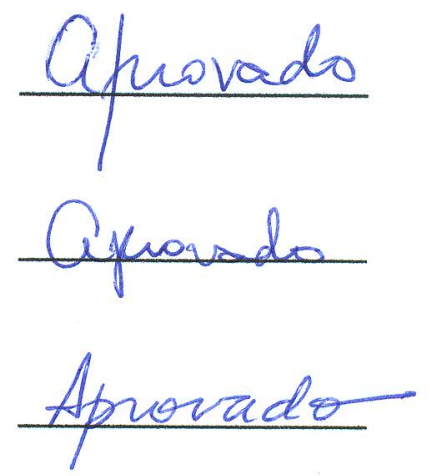

Coordenador do Programa de Pós-Graduação em Engenharia de Transportes:

Prof. Associado Antônio Nélson Rodrigues da Silva

Presidente da Comissão de Pós-Graduação:

Prof. Titular Denis Vinicius Coury 
À minha esposa que amo sem fim, Gislene, pelo companherismo, amor e carinho no dia-a-dia

À minha mãe, Soila Brilhante, Ao meu pai, João Marivaldo, Aos meus irmãos, Patrícia e Patrick, que mesmo distantes sempre me apoiaram 


\section{Agradecimentos}

A Deus pela oportunidade.

Ao professor Eiji, ser humano fantástico e amigo, pelos ensinamentos passados ao longo deste trabalho.

Ao Governo Federal, através da Universidade Federal de Roraima e da Coordenação de Aperfeiçoamento de Pessoal de Nível Superior - CAPES, pelo auxílio financeiro.

À Universidade de São Paulo pela concessão de espaço físico, material e conhecimento através do seu corpo docente ao longo destes anos de Doutorado.

À Secretaria dos Transportes Metropolitanos do Estado de São Paulo, em especial à Coordenadoria de Relações Institucionais, pela cessão dos dados da Pesquisa Origem-Destino da Região Metropolitana da Baixada Santista (RMBS).

À Agência Metropolitana da Baixada Santista pela cessão de dados acerca da infraestrutura cicloviária existente na RMBS.

Às Prefeituras Municipais de Guarujá-SP, Santos-SP e São Vicente-SP pelo atendimento às solicitações de informações sobre ciclovias e ciclofaixas implantadas.

Ao professor Antônio Nélson pela amizade e ajuda com o TransCAD.

À Arquiteta Tamara G. Medvedchikoff pela ajuda com informações e mapas da RMBS.

Aos amigos e professores Bruno Bertoncini e Mateus Araújo pela ajuda na escrita do projeto inicial desta Tese de Doutorado e pelo apoio e amizade ao longo destes anos de Doutorado. 
Aos amigos de pedal do STT: Carlos Prado, Zanchetta, e Manoel Sória pela amizade e, principalmente, paciência quando estava começando a pedalar nas proximidades de São Carlos-SP.

Aos companheiros de pedal "sangue no zóio" de toda terça-feira, quinta-feira e domingo, com saída da Rios Bike: Rui Mello, Miguelito, Gabriel Arab, Amilcar, Delano, Maksuel, Francisco Mello, Marcos Oishi, Mauro, Rodrigo, Fernando Lumini, Fernando Barby, Márcio, Anderson, Ricardo e vários outros, pela amizade, paciência e companheirismo na hora do "sufoco" que, às vezes, estamos sujeitos nas trilhas de bicicleta.

Aos amigos do Departamento de Transportes da EESC-USP: Bruno, Mateus, Carlos Prado, Fábio Zanchetta, André Cunha, Luis Miguel, Vivian, Elievam, Andressa, Monique, Diego, Alex, Victor Baiano, Gustavo, Robert, Luciana, Isabelle, Fernando, Marcela, Thiago, Wallace, Wilson, Jesner, Prof. Sérgio, Prof. Mário, Gigante, Joãozinho, Paulo Toyama, Beth, Magaly, Suely, Alexandre e vários outros pela ótima convivência no STT.

Ao corpo docente do STT pelos ensinamentos transmitidos.

Aos amigos Daniel Mochiutti, Paulo Mattos e Thales Miranda pelos momentos de descontração vividos em São Carlos.

Aos amigos do colégio NPI: Dorivaldo, Cardias, André, Giovanni e Charles que sempre se reúnem quando estão todos em Belém-PA e fazem uma farra das boas.

À minha amiga Cira, minha amiga e madrinha de casamento, pela amizade diária.

Ao amigo Marcelo Massulo que, sempre quando possível, nos comunicamos e perguntamos como cada um está.

À minha família, dedico um especial agradecimento por toda torcida. 
"Se a educação sozinha não pode transformar a sociedade, tampouco sem ela a sociedade muda”.

Paulo Freire 

de São Carlos, Universidade de São Paulo.

A meta deste trabalho é propor um procedimento para identificar e quantificar os fatores que influem no uso de bicicletas e apresentar a forma como estes fatores podem ser usados para avaliar e planejar a implantação de ciclovias e/ou ciclofaixas em uma área urbana. Para tanto, foi elaborado um método que consistiu, inicialmente, de obtenção de dados socioeconômicos e de viagens urbanas de locais dotados de ciclovias e/ou ciclofaixas disponíveis para a população e de contagens volumétricas de ciclistas antes e depois da implantação da infraestrutura cicloviária. Em seguida, foi realizado um experimento que consistiu de caracterização dos dados socioeconômicos, de viagens urbanas e de infraestrutura cicloviária, a partir das quais foi estimado um modelo de escolha discreta que possibilitou a identificação de fatores que influem no uso da bicicleta na RMBS e que serviu para quantificar a demanda cicloviária em pontos preestabelecidos. Através da construção de cenários antes e depois da implantação da infraestrutura cicloviária e da comparação entre contagens volumétricas de ciclistas da RMBS, realizadas em vários pontos da rede viária, e a estimação da demanda cicloviária nestes pontos usando o modelo de escolha discreta, concluiu-se que o modelo permite identificar e quantificar os fatores e a forma como eles interferem na demanda cicloviária e que, portanto, os resultados podem ser usados para avaliar e direcionar as intervenções no sistema de transportes com o intuito de facilitar o uso do modo bicicleta.

Palavras-chave: planejamento cicloviário; uso da bicicleta; modelos de escolha discreta; características socioeconômicas, infraestrutura cicloviária; ciclovias; e ciclofaixas. 
SOUSA, P.B. (2012) Analysis of Factors that Influence the Use of the Bicycle for Bicycle Facility Planning. 190 p. Tese (Doutorado) - Escola de Engenharia de São Carlos, Universidade de São Paulo.

The main aim of this work is to propose a procedure to identify and quantify the factors that influence the use of bicycles and to present how these factors can be used to evaluate and plan the deployment of segregated bike lanes and/or cyclelanes in an urban area. For attaining the aims, a method was developed and consisted firstly in to obtain socioeconomic data and urban travel data in places equipped with segregated bike lanes and/or cyclelanes available to the population and with counts of cyclists before and after the implementation of cycling infrastructure. Then, an experiment was conducted which consisted of characterization of the socioeconomic data and urban trips and cycling infrastructure from which a discrete choice model was estimated that allowed the identification of factors that influence the use of bicycles in a RMBS and was used to quantify the cycling demand on predetermined points. By the construction of scenarios before and after the implementation of cycling infrastructure and the comparison between counts of cyclists in a RMBS and the estimation of cycling demand in these points using discrete choice model, the main conclusion of this work is that the model allow us to identify and quantify the factors and how they interfere in a cycling demand. Therefore the results can be used to evaluate and direct interventions in the transport system in order to facilitate use of bicycle mode.

Keywords: bicycle facility planning; use of bicycle; discrete choice models; socioeconomic characteristics, infrastructure cycling; segregated bike lanes; and cyclelanes. 
1. INTRODUÇÃ

1.1. Contextualização do Tema .................................................................13

1.2. Meta e Objetivos da Tese de Doutorado ................................................15

1.3. Breve Descrição da Tese .....................................................................16

1.3.1. Linha de pesquisa ......................................................................... 16

1.3.2. Síntese do método elaborado para realização da Tese de Doutorado.....17

1.4. Justificativa para Realização da Tese de Doutorado ................................. 18

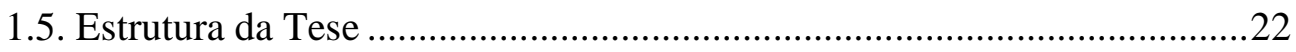

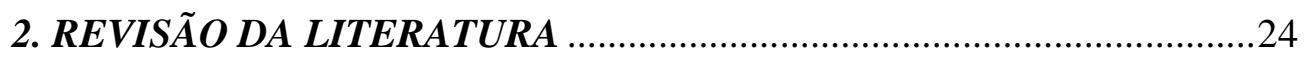

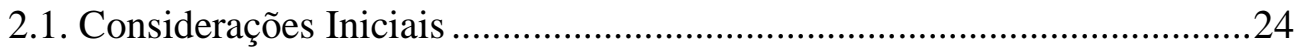

2.2. Fatores que Influenciam a Demanda Cicloviária ......................................24

2.3. Exemplos de Infraestrutura Cicloviária .......................................................32

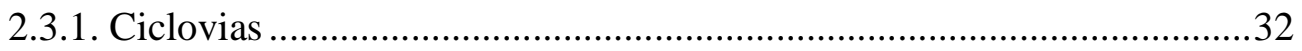

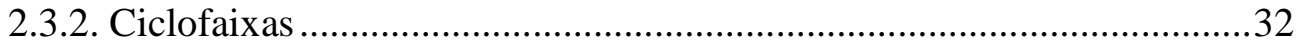

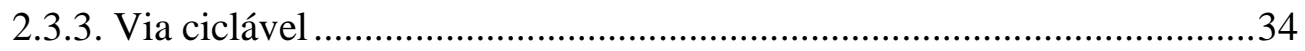

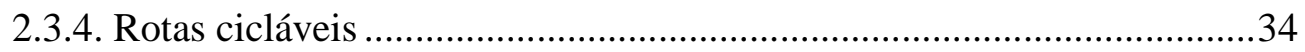

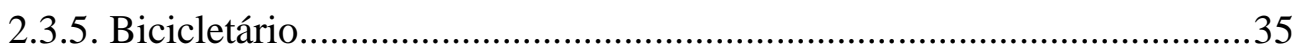

2.3.6. A infraestrutura cicloviária considerada na Tese de Doutorado...............35

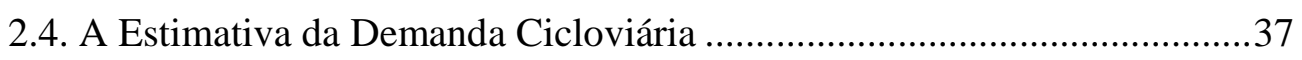

2.4.1. Contextualização da Tese de Doutorado na literatura existente..............46

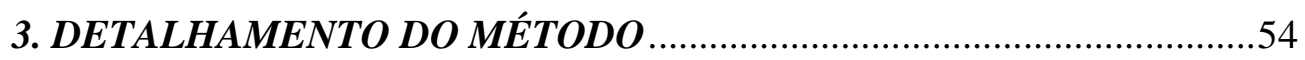

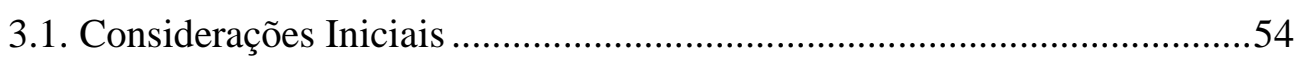

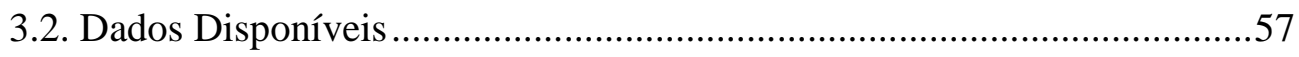


3.3. Caracterização Socioeconômica, das Viagens Urbanas e da

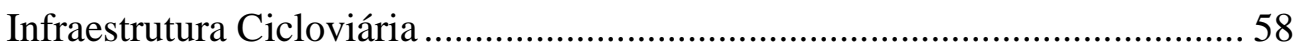

3.4. Estimação de um Modelo de Escolha Discreta.......................................... 65

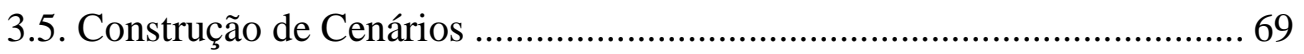

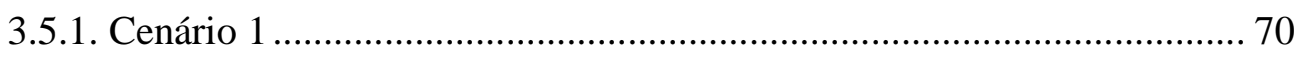

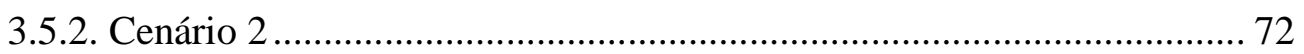

3.5.3. Síntese do detalhamento do método................................................. 75

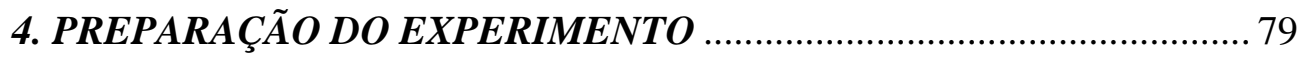

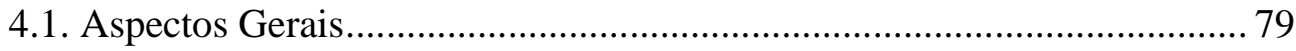

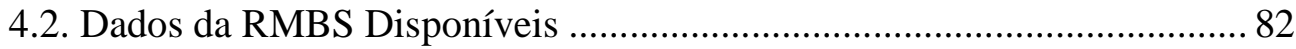

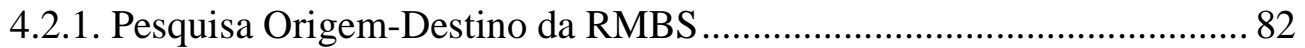

4.2.2. Plano Cicloviário Metropolitano da RMBS .......................................... 92

4.2.3. Caracterização socioeconômica, de viagens urbanas e de

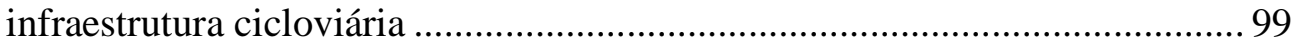

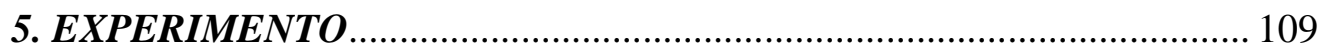

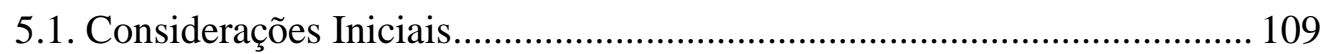

5.2. Especificação do Modelo de Escolha Discreta e Resultado....................... 110

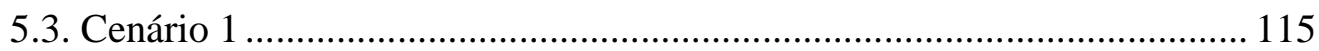

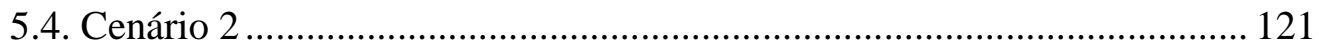

6. ANÁLISE E DISCUSSÃO DE RESULTADOS ….............................. 141

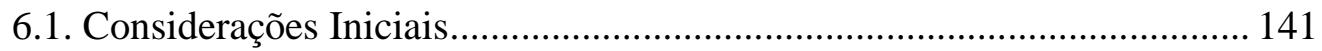

6.2. Análise da Especificação do Modelo de Escolha Discreta

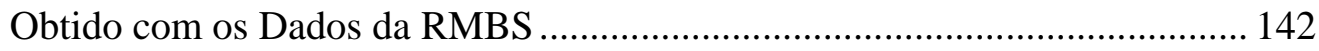

6.2.1. Análise da especificação da função utilidade para o modo Privado ...... 143 


\section{SUMÁRIO}

แบ

6.2.2. Análise da especificação da função utilidade para o modo Público........144

6.2.3. Análise da especificação da função utilidade para o modo A pé ............146

6.2.4. Análise da especificação da função utilidade para o modo Bicicleta.....146

6.3. Análise dos Cenários 1 e 2 ....................................................................152

6.3.1. Análise das viagens da O/D consideradas nos pontos de contagem.......155

6.3.2. Análise das modificações em variáveis socioeconômicas e do

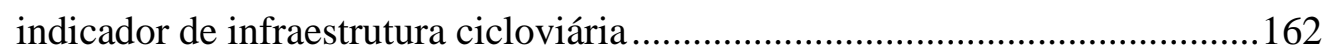

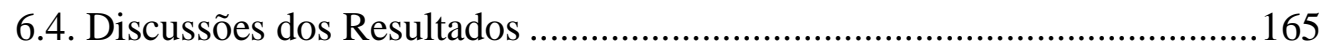

7. CONCLUSÕES E SUGESTÕES PARA TRABALHOS FUTUROS ........170

7.1. Breve Exposição da Tese de Doutorado....................................................170

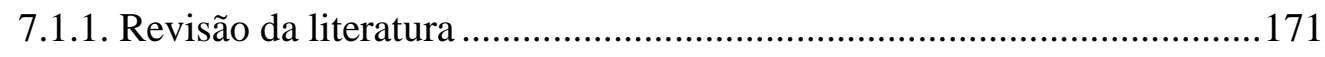

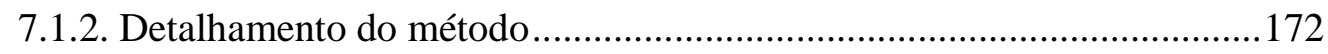

7.1.3. Preparação do experimento e experimento..............................................173

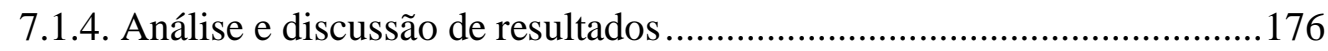

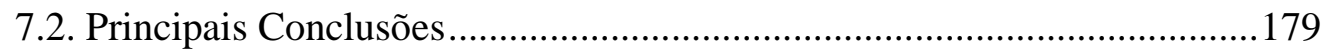

7.3. Sugestões para Trabalhos Futuros ...............................................................180

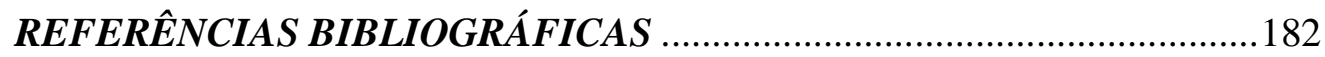




\section{CAPÍTULO 1}

\section{INTRODUÇÃO}

แ

\subsection{Contextualização do Tema}

A necessidade de promover melhores condições de locomoção para os usuários dos modos não-motorizados têm recebido atenção crescente na área de planejamento de transporte nos anos recentes. Os planejadores estão se deparando com um interesse popular crescente no uso da bicicleta e da caminhada, tanto em viagens utilitárias (trabalho e/ou escola) como para saúde e recreação e, além disso, em promover alternativas ao uso do automóvel por razões ambientais e que sejam, de preferência, seguras e convenientes.

Como as decisões de investimento em transportes, frequentemente, requerem a estimativa dos benefícios proporcionados pela infraestrutura construída, Porter et al. (1999) listaram 3 questionamentos, que devem ser respondidos, quando há a intenção de construir ou melhorar a infraestrutura de apoio aos modos não-motorizados. São eles:

- Se forem construídas novas infraestruturas, tais como ciclovias, ciclofaixas, calçadas, estacionamentos, entre outros, quantas pessoas usariam?

- Se forem melhoradas as infraestruturas já existentes ou uma rede de vias para ciclistas e pedestres, quantas pessoas a mais usariam tais facilidades para viajar de bicicleta ou a pé? 
- Quanto diminuiriam os congestionamentos e aumentaria a mobilidade e a qualidade do ar devido às melhorias implementadas aos modos não-motorizados?

As respostas a estes questionamentos podem subsidiar os órgãos responsáveis na decisão de implementar, ou não, a infraestrutura de apoio aos modos não-motorizados. Especificamente, as respostas das duas primeiras questões poderiam ser mais úteis em análises técnicas para escolha prioritária de projetos propostos e a resposta do último questionamento poderia mostrar, junto à sociedade, o benefício proporcionado pelo uso de modos reconhecidamente menos poluentes e de custos mais baixos em comparação com os demais modos de transportes.

De uma maneira geral, detectou-se que não há ainda conhecimento técnico suficiente para analisar as consequências da inserção da infraestrutura cicloviária na circulação do tráfego urbano. O processo de decisão tomado pelos órgãos competentes para a construção da infraestrutura, principalmente no Brasil, leva em conta apenas o número de acidentes envolvendo ciclistas e, em alguns casos, contagens volumétricas.

Alguns estudos já detectaram fatores comportamentais que influenciam a escolha do modo e da rota pelos usuários da bicicleta. Sabe-se que aspectos socioeconômicos, uso e ocupação do solo, tempo de viagem, vias segregadas, entre outras características, podem servir para determinar a maior ou menor propensão ao uso da bicicleta.

Em países europeus, onde o uso da bicicleta é grande, os usuários estão distribuídos entre as diversas classes de renda, ou seja, não importa se é rico ou pobre, muitos utilizam a bicicleta para viagens urbanas e isso é resultado de diversos programas e incentivos proporcionados por seus respectivos governos em prol da bicicleta (PUCHER E BUEHLER, 2008).

No entanto, segundo Nelson e Allen (1997), a análise antes e depois da construção da infraestrutura de apoio aos ciclistas, que ainda não é incorporada nos estudos, poderia servir para capturar satisfatoriamente os efeitos das mudanças na distribuição dos modos de viagem nas cidades. 
É necessário também verificar mudanças que, por ventura, possam ter surgido no cenário econômico durante a inserção da infraestrutura cicloviária na área de estudo. A construção de cenários que representem adequadamente o antes e o depois da implantação desta infraestrutura, inclusive considerando mudanças em setores da economia e demais fatores que influem no uso da bicicleta, pode ser de grande valia na análise do comportamento individual da escolha do modo de viagem da área estudada.

\subsection{Meta e Objetivos da Tese de Doutorado}

A meta desta Tese é propor um procedimento para identificar e quantificar os fatores que influem no uso de bicicletas e de apresentar a forma como estes fatores podem ser usados para avaliar e planejar a implantação de cicloviais e/ou ciclofaixas em uma área urbana. Para isso, são propostos os seguintes objetivos específicos:

(i) Definir como área de estudo o local que disponha de infraestrutura cicloviária para uso da população e de um conjunto de dados individuais com informações socioeconômicas e de viagens urbanas contendo considerável percentual de viajantes urbanos que utilizam a bicicleta como modo de transporte;

(ii) Construir um indicador que represente a infraestrutura cicloviária implantada na área a ser estudada;

(iii) Construir variáveis acerca das informações socioeconômicas e de viagens urbanas individuais;

(iv) Propor a técnica que utilizará as variáveis construídas em (ii) e (iii) e tentará representar quantativamente a escolha do modo cicloviário pelos viajantes urbanos;

(v) Comparar o resultado da técnica utilizada para quantificar a escolha do modo cicloviário (número de viagens de bicicleta) com possíveis contagens volumétricas, existentes em pontos preestabelecidos, atuais e anteriores à implantação da infraestrutura cicloviária; 
(vi) Avaliar se o procedimento permite representar adequadamente os cenários que representam as situações atual e anterior à implantação da infraestrutura cicloviária.

\subsection{Breve Descrição da Tese}

\subsubsection{Linha de pesquisa}

A presente Tese de Doutorado está inserida na linha de pesquisa denominada "Estudo do comportamento de viajantes urbanos”, que vem sendo desenvolvida no Departamento de Engenharia de Transportes da Escola de Engenharia de São Carlos, da Universidade de São Paulo (EESC/USP), sob orientação do Professor Titular Eiji Kawamoto.

Os trabalhos de Ichikawa (2002), Pitombo (2003), Taco (2003), Sousa (2004), Aguiar (2005), Silva (2006), Pitombo (2007) e Silva (2011) foram os trabalhos desenvolvidos nesta linha de pesquisa.

Ao contrário dos estudos que precederam a Tese de Doutorado ora desenvolvida, os quais visavam principalmente a compreensão do comportamento de escolhas referente às viagens urbanas, esta Tese enfoca a aplicação das técnicas já utilizadas para a obtenção de elementos úteis para o planejamento de transportes, especificamente, para a implantação de ciclovias e/ou ciclofaixas em áreas urbanas.

Como são previstas comparações entre quantitativos de demanda cicloviária, obtidos através da modelagem individual de escolha do modo e de contagens volumétricas em pontos preestabelecidos, pretende-se utilizar os modelos de escolha discreta, que são largamente utilizados em planejamento de transportes, pois permitem a construção de funções utilidade que representam adequadamente a escolha do modo através de variáveis significativas estatisticamente e, além disso, atribuem valores e sinais positivos ou negativos para parâmetros de cada variável utilizada nas funções. Em caso de sinal negativo do parâmetro, por exemplo, a variável pode contribuir negativamente para o uso do modo de viagem em questão.

Desta forma, esta Tese de Doutorado propõe seguir a linha de pesquisa acerca do comportamento individual referente às viagens urbanas com o intuito de identificar, e 
quantificar, fatores que influem a escolha do modo cicloviário em áreas urbanas e, caso seja possível, utilizar a modelagem para avaliar e planejar a infraestrutura cicloviária em áreas urbanas.

\subsubsection{Síntese do método elaborado para realização da Tese de Doutorado}

Com base nas hipóteses desta Tese, de que é possível identificar e quantificar os fatores que influem no uso de bicicletas e de que estes fatores podem ser usados para avaliar e planejar a implantação de ciclovias e/ou ciclofaixas em uma área urbana, é proposto um método visando testar e verificar estas hipóteses.

Inicialmente, consistirá na obtenção de dados socioeconômicos e de viagens urbanas de locais dotados de infraestrutura cicloviária (ciclovia e/ou ciclofaixa) disponível para a população. Também, far-se-á a busca por informações de contagens volumétricas de ciclistas antes e depois da implantação da infraestrutura cicloviária em pontos preestabelecidos. Vale ressaltar que, geralmente, somente são feitas contagens antes da implantação da infraestrutura de apoio aos ciclistas.

Após obtenção dos dados necessários à pesquisa, será caracterizada a infraestrutura cicloviária existente, bem como os dados socioconômicos e de viagens urbanas que servirão para aplicação de um modelo de escolha discreta.

Acredita-se que a modelagem a ser utilizada permitirá avaliar, tanto qualitativa quanto quantitativamente, fatores que influem no uso da bicicleta e poderá servir para o planejamento de vias para o uso exclusivo de ciclistas. Para as verificações serão construídos dois cenários:

- Cenário 1: de posse dos pontos de contagem volumétrica de ciclistas, será calculado o número de viagens de bicicletas através do modelo estimado de escolha discreta nestes pontos. Caso não estejam disponíveis valores de contagem após a implantação, os números resultantes através do modelo de escolha discreta serão comparados com as viagens de bicicleta, obtidas diretamente da O/D, e que passam pelos mesmos pontos de contagem. Caso o modelo reproduza o volume adequadamente, será avaliado um novo cenário, caso contrário, serão feitas novas caracterizações; 
- Cenário 2: será recriado o cenário anterior à implantação da infraestrutura cicloviária através de modificações que puderam ser notadas em variáveis socioeconômicas e de infraestrutura cicloviária, e calculado novamente o número de viagens de bicicleta nos pontos preestabelecidos através do modelo de escolha discreta estimado. Posteriormente, os resultados serão comparados com os valores reais da contagem volumétrica de ciclistas antes da implantação da infraestrutura. Caso o modelo reproduza adequadamente o número de viagens nos pontos, as hipóteses deste trabalho estarão satisfeitas. Caso contrário, a segunda hipótese, que consiste no uso do modelo para avaliar e planejar a infraestrutura cicloviária em áreas urbanas, será refutada.

A Figura 1.1 ilustra o fluxograma sintetizado do método elaborado para a realização da Tese de Doutorado.

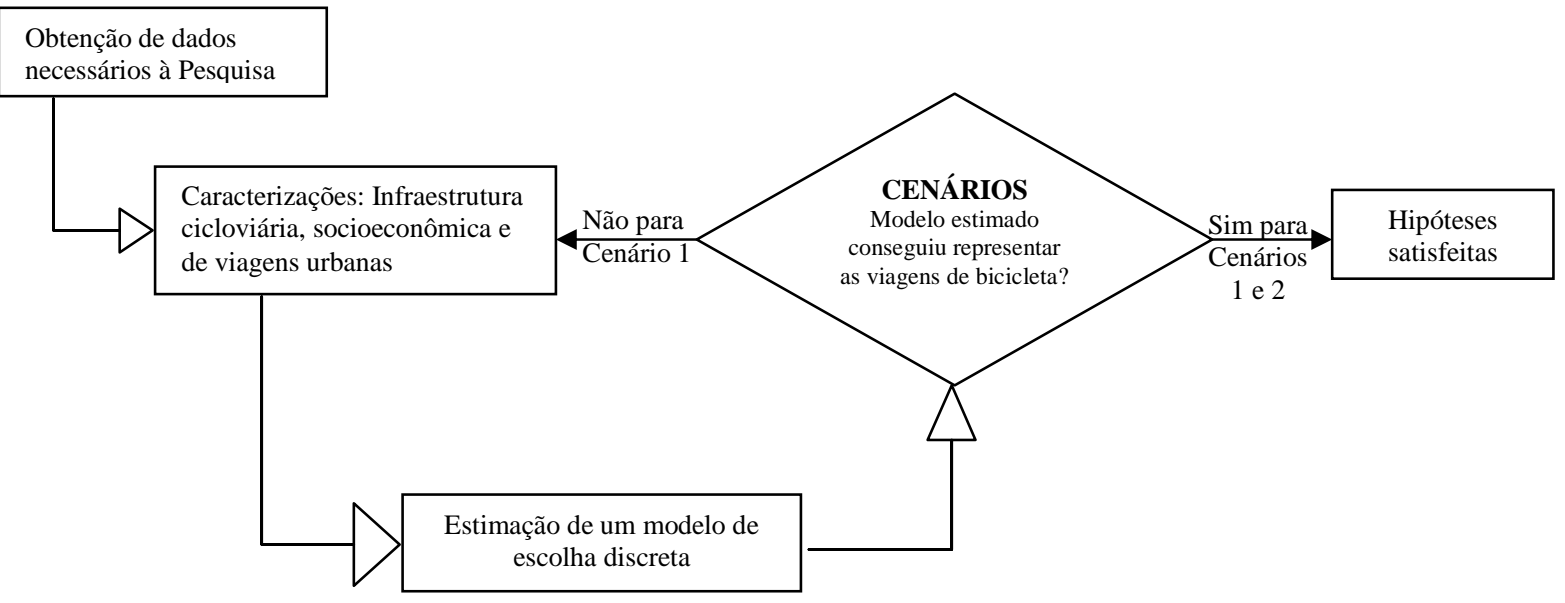

Figura 1.1 - Fluxograma sintetizado do método elaborado

\subsection{Justificativa para Realização da Tese de Doutorado}

Nas últimas duas décadas foi notado o crescente esforço para o entendimento do comportamento da demanda por modos não-motorizados nas cidades. No entanto, estudos que comparam o antes e o depois de construções de facilidades ao modo cicloviário não são comuns e, consequentemente, não é verificada a influência da implantação da infraestrutura nos padrões diários de viagem da população. Juntamente com a análise de variáveis socioeconômicas, geográficas e de transportes, é possível determinar os fatores que influenciam o uso da bicicleta em áreas urbanas. 
Rietveld e Daniel (2004) afirmam que o uso da bicicleta depende de características pessoais, tais como, renda, idade, sexo e padrões de atividade. Por exemplo, a renda familiar pode determinar a posse de veículos como carro, bicicleta ou moto, e isto proporciona um maior conjunto de modos de transporte possíveis de serem utilizados. A idade pode limitar o uso da bicicleta em virtude de características intrínsecas de cada faixa de idade, como habilidade motora e preparo físico. O sexo influencia na escolha do modo cicloviário, pois as mulheres, geralmente, têm menor capacidade física para pedalar e com mais frequência são vítimas de roubos em comparação com os homens. Já a influência dos padrões de atividades surge da necessidade de o indíviduo escolher o modo de transporte mais adequado, e dentro das suas limitações, realizar as atividades diárias como trabalho, estudo, compras etc.

No entanto, segundo os autores, o uso pode variar bastante entre os países e dentro de um mesmo país, devido aos aspectos físicos, demográficos e culturais como, por exemplo, diferenças no relevo e no tamanho da cidade e nas características populacionais intrínsecas de cada área, e a políticas de incentivo ao uso da bicicleta, como maior segurança aos ciclistas e posição de respeito por parte dos usuários de automóveis aos usuários da bicicleta.

Já Barnes e Krizek (2005) afirmam que o problema da estimativa da demanda cicloviária não deve ser tratado de forma comparativa, por exemplo, entre localidades A e B que podem possuir diversas diferenças entre si. Cada localidade, com seus aspectos intrínsecos, deve ser estudada ao longo do tempo com auxílio de prospeccões obtidas pelo uso de pesquisas domiciliares ou contagens volumétricas que capturem as mudanças ocorridas como, por exemplo, as facilidades ao modo cicloviário construídas.

Desta forma, o estudo comportamental da demanda cicloviária dentro de uma mesma área e, se possível, comparando dados obtidos em períodos distintos, que possam capturar as mudanças implantadas no sistema viário e também em variáveis socioeconômicas, pode ser de grande utilidade para o entendimento do comportamento individual da escolha do modo de viagem por parte da população.

No Brasil, ainda são incipientes os estudos sobre o comportamento e de fatores que influenciam a demanda cicloviária. Os trabalhos de Pezzuto (2002) e Kirner (2006), obtidos 
com auxílio de pesquisas de preferência declarada, foram iniciativas na busca do entendimento sobre este tipo de demanda em cidades brasileiras.

Pezzuto (2002) identificou em Araçatuba-SP, considerada uma cidade de porte médio, os fatores que influenciam o uso da bicicleta como modo de transporte. A amostra, obtida através de aplicação de questionários junto às escolas, em pontos de comércio local e em uma instituição de inserção de adolescentes no mercado de trabalho, foi dividida em três grupos: ciclistas (utilizam a bicicleta para viagens utilitárias), ciclistas casuais (que utilizam a bicicleta somente para lazer e exercício) e os não-usuários (não utilizam a bicicleta por nenhum motivo). Vale destacar que, para os ciclistas, os aspectos mais importantes foram a segurança e o conforto ao pedalar.

Kirner (2006) propôs um método para a definição de rotas cicláveis em áreas urbanas. O método proposto, aplicado na cidade de São Carlos-SP, era composto por cinco etapas: identificação do pólo potencial para geração de viagens por bicicletas; coleta de dados sobre o comportamento de viagem dos usuários; identificação dos segmentos de vias onde existe maior demanda potencial de viagens por bicicletas; avaliação do nível de serviço dos segmentos de vias selecionados; e priorização dos segmentos de vias com maior necessidade de melhoramentos para definição das rotas cicláveis.

Não é uma tarefa das mais simples a implantação de infraestrutura de transportes em áreas já bastante adensadas populacionalmente. Isto pode levar a gastos significativos com desapropriações, demolições, construções, entre outros, que precisam ser cuidadosamente avaliados e planejados.

É papel dos planejadores de sistemas de transporte buscarem métodos que auxiliem os gestores governamentais em decisões acerca da escolha de onde e quando investirem na implantação, ou na melhoria de infraestrutura já existente, de sistemas de transportes nas cidades em busca da melhor qualidade de vida para a população. Atualmente, algumas cidades brasileiras e regiões metropolitanas já procuram se adequar à realidade do uso de modos sustentáveis ambientalmente, seja através de investimentos em modos reconhecidamente não poluentes, como as bicicletas, ou no transporte público para a população. 
Entretanto, ainda pode ser considerado insuficiente o conhecimento, principalmente no Brasil, sobre o comportamento do usuário da bicicleta em relação aos aspectos que o fazem escolher o modo e a rota escolhida. Sem o conhecimento, pode ser maior a possibilidade de serem gerados erros como, por exemplo, de localização ou de dimensionamento da infraestrutura.

Um estudo feito nas cidades de Saint Paul e Minneapolis, localizadas no estado norteamericano de Minnesota e chamadas de "cidades gêmeas", mostrou que as rotas utilizadas pelos ciclistas não percorriam as ciclovias e ciclofaixas construídas e um dos principais motivos seria que a infraestrutura foi construída adjacente às vias de fluxo motorizado e que eram congestionadas. Segundo os autores, os potenciais conflitos de tráfego e o fato de que grande parte das viagens eram recreacionais, em que os usuários não necessitavam da malha interligada ao sistema viário e também localizada em áreas de desenvolvimento urbano denso, foram as justificativas para o menor uso da infraestrutura cicloviária implantada nas cidades (DAVIS E WICKLATZ, 2001).

Desta maneira, um método capaz de avaliar a hipótese de que o problema da escolha do modo cicloviário em áreas urbanas deve ser tratado como um processo que envolve fatores socioeconômicos, geográficos e de transportes, além de potencialidades surgidas pela implantação de facilidades ao modo cicloviário capturadas através de indicadores, deve ser considerado uma ferramenta útil de planejamento de transporte pois servirá para auxiliar na decisão de implantar ou não facilidades ao modo de transporte.

O agravamento dos problemas urbanos causados pelo crescimento do número de automóveis como, por exemplo, poluição, perda do espaço urbano, uso inadequado dos recursos energéticos, iniquidade de acesso, exigência de constantes ampliações do sistema viário para acomodação da demanda crescente, entre outros, incentivam a busca por novas alternativas de modos de transporte que promovam uma melhor qualidade de vida para as populações urbanas.

A bicicleta, além de não poluente, silenciosa, econômica, discreta e acessível a todos os membros da família, pode ser considerada um modo de transporte rápido e eficiente nos trajetos urbanos curtos, e possibilita uma melhor acessibilidade à população (AQUINO, 2007). 
Assim, é de fundamental importância que os centros de pesquisa cientifica incentivem cada vez mais as pesquisas e estudos em relação aos modos não-motorizados, especialmente a bicicleta, a fim de buscar contribuições à solução dos inúmeros problemas urbanos mencionados anteriormente.

Apesar de conhecidas as vantagens do modo cicloviário, para viagens curtas e médias ou como modo de acesso ao transporte público, como já dito, poucos são os especialistas e as publicações nacionais que dão ênfase a este transporte. Isto prejudica, inclusive, a valorização do modo e a criação de políticas públicas para o setor.

No Brasil essa missão torna-se ainda mais difícil pois o automóvel é símbolo de status e a bicicleta ainda é esquecida por diversos motivos, entre eles, a insegurança, a topografia e o clima. No entanto, não se pode esquecer que se trata de um veículo que traz enormes benefícios às cidades, à coletividade e aos indivíduos, sendo um importante aliado na busca de melhor qualidade de vida da população urbana.

\subsection{Estrutura da Tese}

A estrutura da Tese de Doutorado está dividida em sete (7) capítulos, a começar por esta introdução.

No segundo capítulo será apresentada a revisão da literatura sobre o transporte cicloviário e tratará de temas que envolvem os fatores que influenciam a demanda cicloviária, exemplos de infraestrutura cicloviária existentes, a estimativa da demanda cicloviária em áreas urbanas e o uso de indicadores em áreas urbanas.

No terceiro capítulo será apresentado o detalhamento do método a ser utilizado com descrição dos dados necessários à pesquisa, da caracterização destes dados, da estimação de um modelo de escolha discreta e da construção de cenários que tentarão simular o comportamento individual da escolha do modo cicloviário antes e depois da implantação de ciclovias e/ou ciclofaixas em uma determinada área urbana. 
O quarto capítulo trará a preparação do experimento que consistirá, basicamente, da caracterização dos dados disponíveis para a pesquisa.

O quinto capítulo será o experimento que apresentará os resultados da estimação do modelo de escolha discreta e dos cenários construídos para representar as situações atual e anterior à implantação da infraestrutura cicloviária (ciclovias e/ou ciclofaixas).

No sexto capítulo serão apresentadas as análises dos resultados, com uma breve discussão dos mesmos. E por fim, no sétimo capítulo serão apresentadas as conclusões e as recomendações para trabalhos futuros. Finalizando o texto, têm-se as referências bibliográficas. 


\section{CAPÍTULO 2}

\section{REVISÃO DA LITERATURA}

แ

\subsection{Considerações Iniciais}

Neste capítulo será apresentada a revisão da literatura sobre o transporte cicloviário em áreas urbanas, principalmente, os trabalhos que envolvem os seguintes temas:

- Fatores que influenciam a demanda cicloviária;

- Exemplos de infraestrutura cicloviária existentes;

- A estimativa da demanda cicloviária em áreas urbanas.

\subsection{Fatores que Influenciam a Demanda Cicloviária}

Segundo Rietveld e Daniel (2004), diversos fatores influenciam a demanda cicloviária em áreas urbanas. A Figura 2.1 mostra a adaptação do fluxograma sugerido pelos autores sobre estes fatores. 


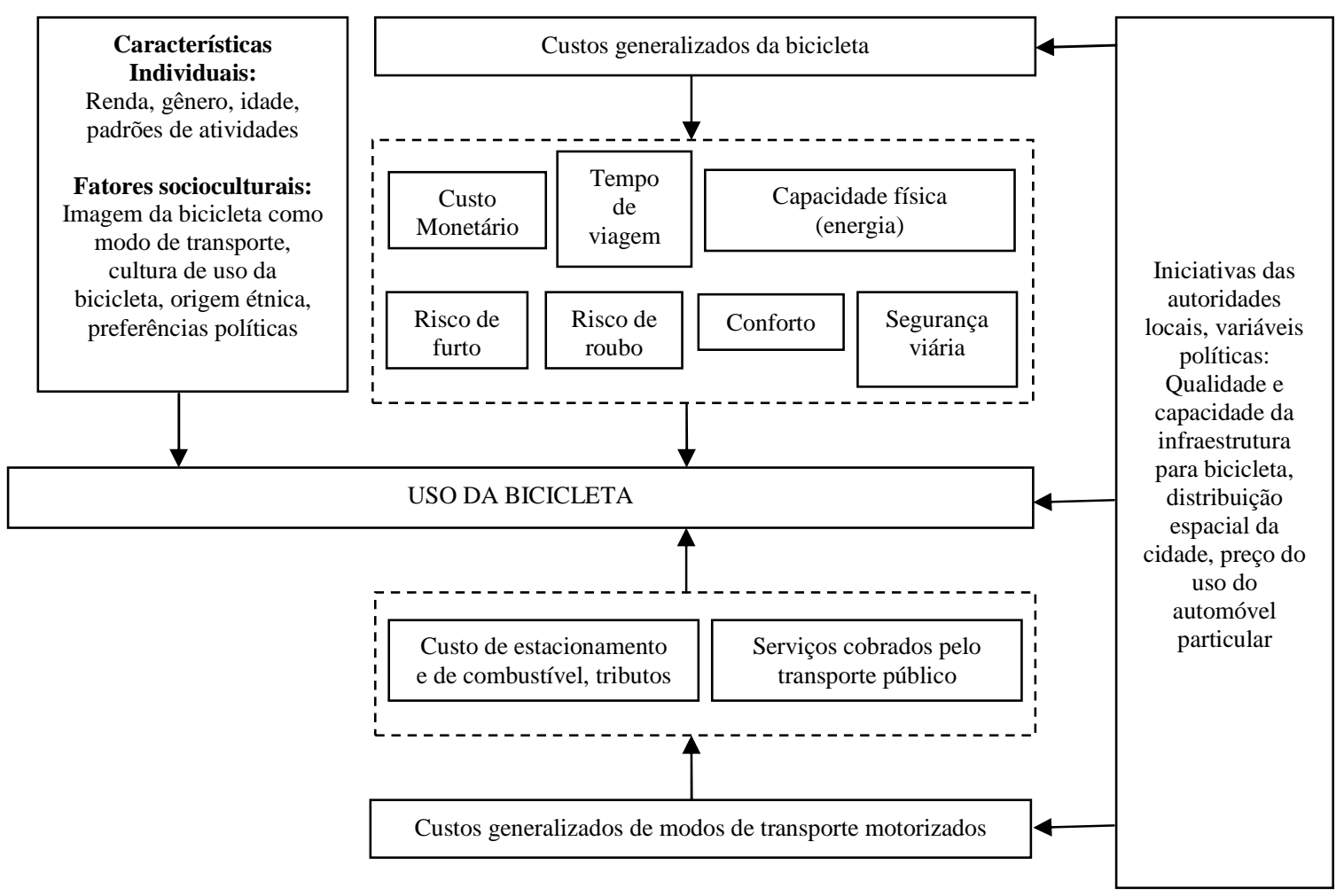

Figura 2.1 - Fluxograma adaptado de Rietveld e Daniel (2004) sobre fatores que influenciam a demanda cicloviária

O uso da bicicleta depende de características individuais, tais como a renda, idade, gênero e padrões de atividades. A renda determina a posse de veículos que, por sua vez, acarreta impacto na escolha individual do modo de transporte. A idade restringe o uso da bicicleta, já que pessoas mais idosas, geralmente, não dispõem de capacidade física para pedalar. As mulheres estão mais sujeitas aos riscos sociais (por exemplo, assaltos) do que os homens. Os padrões de atividades individuais tais como trabalho, ir à escola, visitar amigos ou viagens para tratar de assuntos particulares também influenciam a escolha do modo de viagem.

De acordo com o fluxograma da Figura 2.1, os fatores que dizem respeito aos custos generalizados da bicicleta são:

- Tempo de viagem: depende da estrutura espacial das cidades; da presença ou não da infraestrutura cicloviária; tempo de espera nas interseções etc.;

- Capacidade física (energia) e conforto: estes fatores dependem do traçado e da qualidade das vias disponíveis para uso da bicicleta e do preparo físico dos indivíduos. 
O relevo não plano e níveis elevados de poluição atmosférica combinado com temperaturas altas, por exemplo, afetam negativamente o uso da bicicleta;

- Segurança viária: devido à interação com modos de transporte motorizados há a necessidade de medidas de segurança viária, como a sinalização horizontal e vertical adequada, que proporcionam maior segurança ao ciclista no tráfego compartilhado;

- Riscos de roubos e furtos: se os riscos são altos, as pessoas podem relutar em utilizar a bicicleta ou evitar o uso de modelos de bicicleta melhores que poderiam encorajá-las a fazer rotas mais longas e com maior frequência (Rietveld e Koetse, 2003);

- Custo monetário da bicicleta: inclui os custos provenientes da manutenção e da permanência em bicicletários.

Por outro lado, podem ser considerados como custos generalizados dos modos de transporte motorizado: custo de combustível e de tributos e custos provenientes do uso de transporte público. Quanto maiores forem os custos dos modos motorizados e menores forem os recursos das pessoas para custear os deslocamentos do dia-a-dia, maior a probabilidade de uso de modos não-motorizados, como a bicicleta, que é reconhecidamente mais barata do que os modos motorizados.

Obviamente, tanto os custos do uso da bicicleta como dos modos de transporte motorizados podem ser afetados por iniciativas das autoridades locais e políticas de incentivo ou não. Estas autoridades podem, por exemplo, implementar ações diretas de reorganização da estrutura espacial e prover infraestrutura adequada às necessidades dos usuários da bicicleta, tanto em termos de qualidade como de capacidade, e promover o maior uso da bicicleta em áreas urbanas.

Dill e Carr (2003) afirmam que somente a infraestrutura extensa composta por ciclovias/ciclofaixas não é suficiente para que haja elevadas taxas de uso de bicicletas em uma cidade. É necessário que a infraestrutura esteja inserida em ligações de grande movimento, tanto na origem como no destino, e que estejam disponíveis bicicletários seguros aos ciclistas. Além disso, campanhas publicitárias que incentivem a população sobre os benefícios do uso da bicicleta contribuem para o aumento da demanda cicloviária. 
Alguns trabalhos mostram que os fatores que influenciam o uso da bicicleta podem variar de acordo com percepções e preferências dos diferentes tipos de ciclistas existentes (AXHAUSEN E SMITH, 1986; EPPERSON et al., 1995; FORESTER, 1986; SORTON E WALSH, 1994). Renda, idade, nível de experiência do ciclista, ocupação do indivíduo e propósito da viagem foram as variáveis básicas utilizadas para capturar essas diferenças.

Grupos de ciclistas experientes, por exemplo, consideram tanto ciclovias (vias segregadas para uso de modos não motorizados) quanto ciclofaixas (faixas delimitadas para uso de bicicleta adjacente ao tráfego motorizado) suficientemente seguras para pedalar. Já grupos menos experientes preferem as ciclovias.

Gatersleben e Haddad (2010) conduziram uma pesquisa com 244 pessoas, entre ciclistas e não-ciclistas, com o objetivo de caracterizar um ciclista típico. Foram distinguidos quatro estereótipos:

- Grupo 1 (em inglês: “responsible bicyclists”): este grupo pedala com responsabilidade e com equipamentos básicos de segurança (capacete, luz de freio, retrovisores etc.) apesar de não utilizar a bicicleta com frequência;

- Grupo 2 (em inglês: "lifestyle bicyclists"): considera a bicicleta como "estilo de vida" e não se preocupam em gastar recursos financeiros com bicicletas modernas, vestimentas e acessórios para o modo. Utilizam com frequência moderada sendo, principalmente, para uso em atividade física;

- Grupo 3 (em inglês: “Commuters”): grupo de pessoas jovens, do sexo masculino, que utilizam a bicicleta no seu dia-a-dia para quaisquer atividades;

- Grupo 4 (em inglês: “hippy-go-lucky bicyclists”): usa a bicicleta para atividades não relacionadas com trabalho como, por exemplo, compras. Chegam a utilizar a bicicleta diariamente, porém, não se preocupam com equipamentos de segurança. 
Os grupo 3 e 4 são os principais responsáveis pelos deslocamentos em áreas urbanas. Geralmente, as pesquisas procuram entender o comportamento das pessoas inseridas nestes grupos e, assim, explicar os fatores que são determinantes para o uso da bicicleta diariamente.

$\mathrm{Na}$ Inglaterra, Ashley e Banister (1989) usaram a ocupação e a posse de automóveis, variáveis relacionadas com a renda do indivíduo, e concluíram que as viagens de bicicleta decrescem com o aumento no valor destas variáveis. Em outro estudo em Davis, Califórnia, as taxas de viagens de bicicleta aumentam entre as ocupações que envolvem vendedores, mecânicos ou operários da construção em comparação com profissões que requerem grau de instrução superior (LOTT et al., 1977).

Ortuzar et al. (2000) citam alguns fatores que, reconhecidamente, afetam o uso da bicicleta em áreas urbanas: distância e duração da viagem; topografia; e segurança. Particularmente, estes fatores mencionados dependem de políticas públicas de incentivo ao uso da bicicleta, seja através de rotas que ofereçam rapidez, segurança e conforto ao ciclista, seja através de infraestruturas no destino das viagens, como bicicletários e vestiários para usuários da bicicleta.

A FHWA (2003) afirma que os fatores que influenciam a decisão de usar modos não motorizados estão divididos entre os seguintes itens:

- Percepções e necessidades iniciais: é intrínseca de cada indivíduo a percepção da utilidade dos modos de transporte para realizar determinado tipo de viagem. Por exemplo, cada indivíduo irá avaliar se a bicicleta irá atender adequadamente o transporte de compras feitas no supermercado ou não, se permitirá levar os filhos à escola etc.;

- Características das viagens: se a rota a ser utilizada entre origem e destino dispõe de vias projetadas para o uso da bicicleta que diminuem o tempo de viagem e proporcionam maior segurança ao pedalar, se há fluxo e velocidade alta por parte dos veículos motorizados, se há poluição etc.;

- Características nos destinos: se há local seguro para a permanência da bicicleta, existência de vestiários para asseio do usuário da bicicleta etc. 
Desta forma, políticas públicas de incentivo ao uso da bicicleta através do investimento em infraestrutura cicloviária, com o intuito de eliminar as barreiras na viagem e no destino, tais como vias, bicicletários e vestiários para os usuários das bicicletas, possuem um papel importante no incremento da demanda deste modo em áreas urbanas.

Como já dito anteriormente, alguns estudos já foram realizados em diversas partes do mundo com o objetivo de definir o perfil dos usuários e de potenciais usuários do modo cicloviário em áreas urbanas. Nota-se que características socioeconômicas como renda, idade, sexo, escolaridade, além daquelas que envolvam as características das viagens urbanas, como distância e tempo de viagem, podem estar fortemente relacionadas com o processo de escolha pelo uso deste modo nas cidades.

Por exemplo, segundo Horowitz et al. (2010), cerca de $40 \%$ de todas as viagens de bicicleta na Holanda são feitas em distâncias inferiores à $5 \mathrm{~km}$. Para distâncias compreendidas entre 5 e 7,5 km, o percentual de viagens de bicicleta cai para $26 \%$ e para distâncias superiores à $7,5 \mathrm{~km}$ fica em torno de $7 \%$.

Baseado em pesquisas realizadas na Alemanha em 2003, Dinamarca em 2005 e Holanda em 2006, onde o uso da bicicleta é relativamente alto em relação a outros países, Pucher e Buehler (2008) salientam que o percentual de homens e mulheres que utilizam a bicicleta é praticamente igual. Na Dinamarca, $45 \%$ das viagens são feitas por mulheres, na Alemanha esse total é de $49 \%$ e na Holanda são 55\%, diferentemente dos Estados Unidos, onde $24 \%$ das viagens são feitas pelas mulheres.

Com relação à idade, percebe-se altas taxas de uso por parte dos jovens nos países europeus anteriormente mencionados e a relativa queda da utilização a partir do aumento da idade. Nestes países, os ciclistas demonstraram estar distribuídos entre as diversas classes de renda, ou seja, não importa se é rico ou pobre, todos utilizam a bicicleta para viagens urbanas. O uso considerável da bicicleta na Alemanha, Dinamarca e Holanda, segundo vários estudos, é resultado de diversos programas e incentivos proporcionados por seus respectivos governos em prol da bicicleta (PUCHER E BUEHLER, 2008). 
No Brasil, algumas pesquisas já realizadas mostram que a realidade parece ser diferente da européia. Além de ser utilizada somente em áreas periféricas das grandes cidades, a população que a utiliza é reconhecidamente pobre, do sexo masculino e em idade economicamente ativa.

Segundo Dutra (2007), na tentativa de identificar os vetores dos desejos de viagens dos ciclistas na cidade de Londrina-PR, e também as demandas reprimidas por este tipo de transporte, 1000 entrevistas foram realizadas pela Prefeitura de Londrina, durante o mês de Março de 2006, em vias com maior circulação de tráfego e concentração comercial e de serviços, além das empresas com maior quantidade de funcionários no município. Analisando os deslocamentos dos ciclistas, percebe-se que a maioria são homens $(88,4 \%)$, faixa etária até 35 anos $(69,8 \%)$, com renda familiar até $\mathrm{R} \$ 1.000,00(83,8 \%)$ e que se deslocam por motivo de trabalho $(97,6 \%)$ em distâncias entre 0 e 10 km (86,8\%).

Aquino (2007), ao analisar as potencialidades e a viabilidade de integração entre trem e bicicleta em João Pessoa-PB e cidades próximas interligadas pelo trem, realizou uma pesquisa de mobilidade com ciclistas, na qual foram entrevistadas 1373 pessoas. Aproximadamente $80 \%$ da amostra era composta por jovens adultos, entre 20 e 49 anos, ou seja, em idade economicamente ativa, e mais de $90 \%$ eram do sexo masculino.

Para obtenção de dados descritivos de ciclistas, Maia e Moreira (2010) entrevistaram ciclistas circulando na via nas proximidades de um Terminal de Integração de Transporte Coletivo em Fortaleza-CE. Os principais resultados foram:

- Sexo: a participação das mulheres na composição geral dos usuários da bicicleta ainda é muito reduzida. Apenas $2 \%$ dos entrevistados eram do sexo feminino;

- Faixa etária: a maioria dos ciclistas entrevistados tem idade entre 21 anos e 35 anos $(44 \%)$, caracterizando um grupo de jovens adultos;

- Escolaridade: observou-se que grande parte dos entrevistados possui baixa escolaridade: $37 \%$ com o $1^{\circ}$ grau completo e $35 \%$ sem o $1^{\circ}$ grau; 
- Profissão: a maioria dos entrevistados é constituída por trabalhadores da construção civil, que utilizam a bicicleta por ser uma alternativa barata de deslocamento, mesmo com grandes distâncias a serem percorridas. Os percentuais foram: 32\% para construção civil, 25\% para auxiliar administrativo, $11 \%$ para vendedor, $11 \%$ para comerciário, 5\% para metalúrgico etc.;

- Ocupação: a bicicleta é utilizada por trabalhadores empregados, correspondendo a $76 \%$ dos entrevistados, e trabalhadores autônomos (24\%). Esses números se relacionam com o motivo de viagem mais encontrado (trabalho);

- Renda média mensal: os dados demonstraram a popularidade da bicicleta entre as camadas sociais de baixa renda em Fortaleza-CE. A grande maioria dos entrevistados (79\%) revelou que ganha entre 1 e 2 salários mínimos;

- Posse da bicicleta: 94\% respondeu que são donos de bicicleta;

- Tempo de viagem: a maioria das viagens tem duração de 30 minutos a 1 hora (54\%), em seguida, menos de 30 minutos (29\%). Entre $1 \mathrm{~h}$ e $1 \mathrm{~h} 30 \mathrm{~min}$ e acima de $1 \mathrm{~h} 30 \mathrm{~min}$ corresponderam a $13 \%$ e $5 \%$, respectivamente. Segundo os autores, em média, os ciclistas entrevistados percorrem distâncias entre 6 e 14 km;

- Origem e destino das viagens: como observado, a maioria dos entrevistados é trabalhador da construção civil e mora em bairros distantes do seu trabalho. Observouse que o município de Caucaia, localizado na Região Metropolitana de Fortaleza-CE, a uma distância em torno de $15 \mathrm{~km}$ do local das entrevistas (Terminal de Integração de Transporte Coletivo), foi bastante citado como local de moradia dos ciclistas. O local de destino mais citado foi o bairro de Aldeota, localizado na zona leste da cidade, onde a densidade populacional é elevada e a área oferece grande oferta de emprego e serviços, principalmente no setor da construção civil, devido à valorização da área. Para chegar a este destino, por exemplo, os ciclistas chegam a percorrer aproximadamente $20 \mathrm{~km}$. 
Desta forma, com o intuito de subsidiar políticas públicas de implantação e melhorias do sistema de transporte cicloviário, é de suma importância que sejam levantadas as características socioeconômicas dos viajantes urbanos e os aspectos regionais onde são realizados os estudos de demanda, bem como as características das viagens realizadas e de infraestrutura cicloviária já existente.

\subsection{Exemplos de Infraestrutura Cicloviária}

Segundo o GEIPOT (2001), um sistema cicloviário consiste de uma rede integrada composta de elementos com características de vias, terminais, transposições, equipamentos etc, que atendam à demanda e à conveniência do usuário da bicicleta em seus deslocamentos, especialmente em termos de segurança e conforto. A seguir, descrevem-se os principais itens que compõem o sistema cicloviário.

\subsubsection{Ciclovias}

As ciclovias, vias para ciclistas segregadas do tráfego geral, podem seguir paralelas ao sistema viário geral ou de forma independente. São separadas fisicamente das faixas destinadas ao transporte motorizado por um meio-fio ou canteiro, que só é excluído em raras interseções. Por ser segregada, é considerada a via que apresenta o maior nível de segurança e conforto aos ciclistas. As principais desvantagens são relacionadas ao fato de que a segregação dificulta ou mesmo impede o acesso aos lotes e os problemas de conflito, como o tráfego motorizado em interseções e a maior dificuldade de transposição de obstáculos como, por exemplo, as rotatórias.

Podem ser tanto unidirecionais quanto bidirecionais. As unidirecionais são comuns em países onde o planejamento cicloviário é tradicional, nos quais os ciclistas seguem regras semelhantes à do tráfego geral. No Brasil, o mais comum são ciclovias bidirecionais (KIRNER, 2006).

\subsubsection{Ciclofaixas}

As ciclofaixas constituem-se de faixas de rolamento destinadas para a bicicleta, com o objetivo de separá-las do fluxo de veículos automotores. Normalmente, localizam-se no bordo 
direito das ruas e avenidas, no mesmo sentido de tráfego, podendo ainda, ser implantadas nas proximidades dos cruzamentos. São sempre indicadas por linhas separadoras, pintadas no solo, ou ainda com auxílio de outros recursos de sinalização (“tachões”, por exemplo).

Segundo o GEIPOT (2001), a implantação de ciclofaixa mais recomendada é a situada junto ao bordo direito (posição 1), no entanto, há as opções entre a área do estacionamento e a borda do meio-fio (posição 2) ao lado da calçada de pedestres; após a linha de estacionamento (posição 3); e quando a largura da faixa de rolamento para os veículos motorizados é superior a 3,5m, a circulação de bicicletas poderá ocorrer na porção excedente da largura padrão da faixa de tráfego motorizado. A Figura 2.2 ilustra as posições citadas anteriormente.
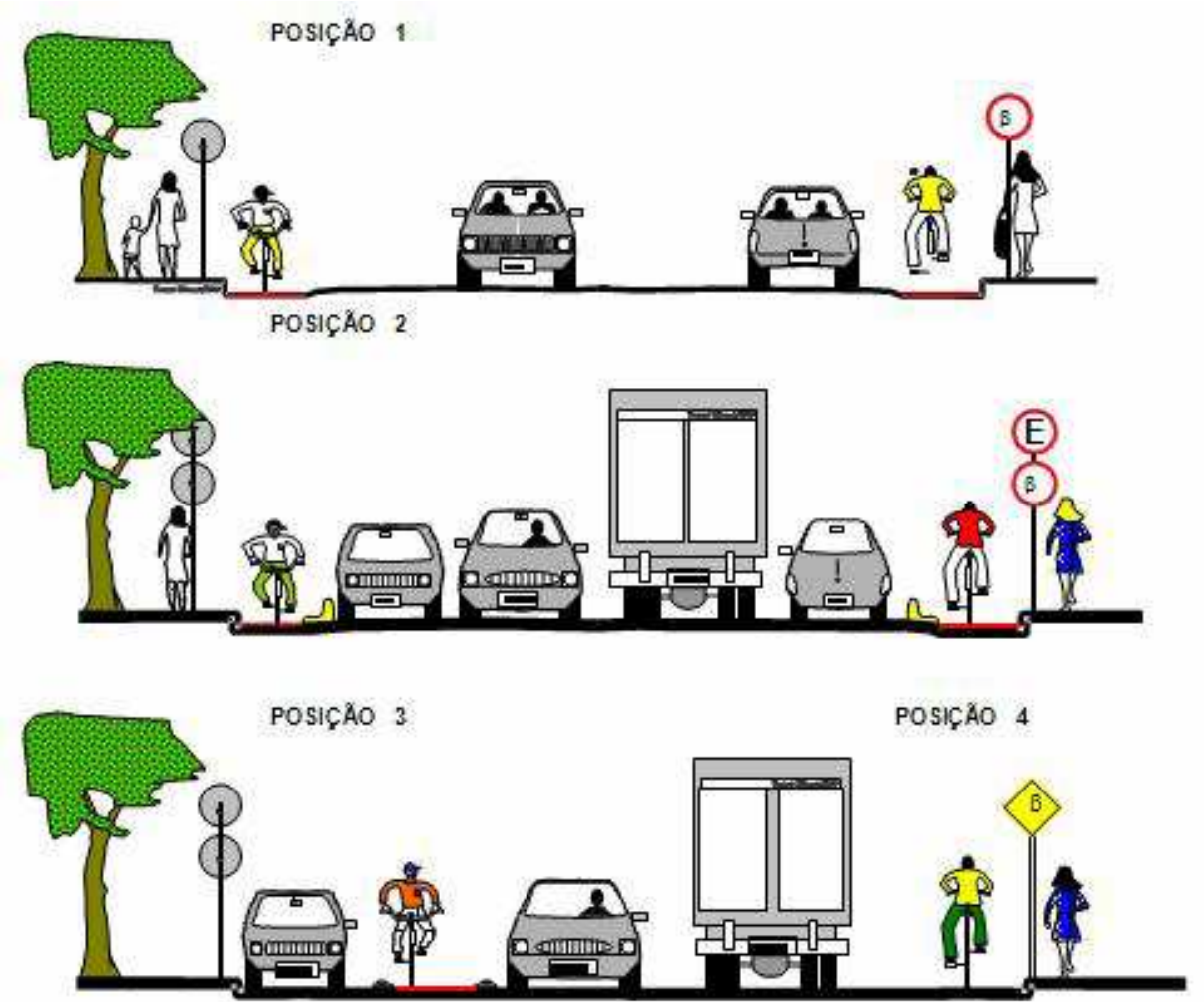

Figura 2.2 - Posições para implantação de ciclofaixas (GEIPOT, 2001)

Mesmo que não haja nem ciclovias e nem ciclofaixas em uma determinada via, há legislação que orienta os ciclistas para que trafeguem com segurança junto ao tráfego motorizado no Brasil. 
O Código de Trânsito Brasileiro (Brasil, 1997) prevê, em seu Art. 58, que:

“Nas vias urbanas e nas rurais de pista dupla, a circulação de bicicletas deverá ocorrer quando não houver ciclovia, ciclofaixa ou acostamento, ou quando não for possível a utilização desses, nos bordos da pista de rolamento, no mesmo sentido de circulação regulamentado para a via, com preferência sobre os veículos automotores".

Também, no CTB no Art. 59, parágrafo único, é previsto:

"Desde que autorizado e devidamente sinalizado pelo órgão ou entidade com circunscrição sobre a via, será permitida a circulação de bicicletas nos passeios”.

\subsubsection{Via ciclável}

A via ciclável decorre da identificação de vias de tráfego motorizado onde a circulação de bicicletas pode se dar de forma segura. Geralmente, são indicadas através de sinalização adequada ou mapas distribuídos aos ciclistas, que definem os caminhos mais convenientes para os ciclistas trafegarem com tráfego compartilhado, desviando de vias congestionadas ou de conflitos em interseções. Em alguns casos, a via ciclável poderá complementar as ciclovias ou ciclofaixas para se chegar ao destino final do usuário de bicicleta.

\subsubsection{Rotas cicláveis}

O conjunto de vias cicláveis, ciclofaixas e ciclovias, que podem ou não ser interligadas, introduz o conceito de rotas cicláveis no meio urbano. É importante salientar que a identificação de rotas cicláveis deve sugerir aos ciclistas que existem vantagens na utilização de tais vias, em detrimento de outros caminhos alternativos. Assim, a definição de rotas cicláveis deve ter amparo dos órgãos responsáveis, garantindo que as rotas são compatíveis com o tráfego de bicicletas e que será realizada manutenção contínua para que estas não se deteriorem. 


\subsubsection{Bicicletário}

É o espaço destinado ao estacionamento de bicicletas, implantados junto a terminais de transporte, em grandes indústrias, em áreas de abastecimento, em parques e outros locais de grande atração de usuários da bicicleta.

A Companhia Paulista de Trens Metropolitanos - CPTM (2008), através do "Projeto Pedalada”, está buscando valorizar o modo cicloviário como forma de acesso à rede de trens metropolitanos da Região Metropolitana de São Paulo, através da instalação de bicicletários nas estações, visando ao atendimento de dois públicos específicos: usuários e funcionários. Segundo o projeto, das 89 estações metroferroviárias, 14 já possuíam bicicletários para atendimento ao público.

Para os usuários dos serviços da CPTM, como público essencial do Projeto, vêm sendo instalados bicicletários nas áreas externas das estações, dotados de controle de acesso e de vigilância permanente para a guarda das bicicletas. Já com relação aos funcionários, é prevista a instalação de paraciclos nas estações, que é o nome dado à estrutura para acorrentamento de bicicletas, e de bicicletários em áreas especiais. Desta forma, destaca-se a importância de valorização do uso da bicicleta como modo de transporte e de acesso às estações nos programas de expansão e modernização da malha da CPTM.

Em resumo, a CPTM elenca os seguintes ganhos obtidos pelo Projeto Pedalada: redução dos tempos de viagem; economia nos custos das viagens integradas; melhoria da micro-economia local pelo aumento da mobilidade dos ciclistas; melhoria da qualidade ambiental; e melhoria das condições físicas das pessoas.

\subsubsection{A infraestrutura cicloviária considerada na Tese de Doutorado}

Nesta Tese de Doutorado, a infraestrutura cicloviária a ser considerada é unicamente composta pelas ciclovias e ciclofaixas implantadas em uma determinada área urbana. Além da infraestrutura, pretende-se identificar e quantificar demais fatores que influem no uso da bicicleta e a forma como estes fatores poderão ser úteis na avaliação e planejamento de ciclovias e ciclofaixas em áreas urbanas. 
Vale citar que a infraestrutura para o modo cicloviário não se resume somente aos itens citados anteriormente. Os equipamentos no sentido de integrar bicicleta e transporte público, modificações de traçado e de interseções entre vias, técnicas de Traffic Calming em áreas residenciais, vestiários, entre outros, são exemplos de melhoramento de infraestrutura do sistema cicloviário.

Desta maneira, o sucesso nas políticas públicas de incentivo ao uso da bicicleta no Brasil deverá estar diretamente relacionado com os melhoramentos previstos na infraestrutura do setor que, em muitas cidades brasileiras, ainda pode ser considerado precário.

O governo federal brasileiro, diante da necessidade de tratamentos mais adequados e a exigência de políticas públicas especificas, lançou o Programa "Bicicleta Brasil” em 2007. Espera-se, entre diversos objetivos, que a bicicleta se torne um modo de transporte cada vez mais comum nas cidades brasileiras.

Segundo Pucher e Buehler (2008), o sucesso no uso da bicicleta nas últimas décadas nos países europeus se deve às ações desenvolvidas nas seguintes áreas:

a) Instalações urbanas melhoradas para uso das bicicletas, tais como, ciclovias, ciclofaixas, modificações nas interseções, entre outras;

b) Traffic Calming em áreas residenciais;

c) Instalações de estacionamentos para bicicletas;

d) Integração com transporte público;

e) Educação e fiscalização de trânsito;

f) Campanhas de incentivo ao uso da bicicleta;

g) Políticas de uso do solo, como zoneamento de uso misto e desenhos urbanos avançados. 


\subsection{A Estimativa da Demanda Cicloviária}

São bastante incipientes os trabalhos que abordam a modelagem da demanda por viagens utilizando bicicletas (KATZ, 1995). Segundo An e Chen (2007), Katz (1995) e Porter et al. (1999), a estimativa da demanda cicloviária pode ser obtida através de modelos matemáticos provenientes tanto de dados agregados quanto desagregados. Os modelos agregados são de caráter regional e estimam a demanda em função das características médias da população das zonas de tráfego ou de regiões. Já os modelos desagregados consideram características intrínsecas dos indivíduos envolvidos com a questão, como renda individual, idade, sexo, entre outras. A seguir, são descritas as principais categorias de modelos utilizados para estimar a demanda cicloviária:

\section{(i) Modelo tradicional de transportes:}

Também chamado de 4 etapas, o modelo utiliza dados socioeconômicos e demográficos, além de informações sobre empregos, matrículas nas escolas etc. e de dados sobre viagens urbanas. São baseados na estrutura espacial das zonas de tráfego inseridas em uma determinada área e que são conectadas por uma rede viária. É um processo que inclui a modelagem matemática, através da utilização dos dados disponíveis, em 4 etapas denominadas de:

a) Geração de viagens: tem como objetivo determinar o número de viagens produzidas e/ou atraídas na área;

b) Distribuição de viagens: nesta etapa, é determinada a distribuição do número de viagens produzidas e/ou atraídas por zonas de tráfego;

c) Escolha do modo: a etapa refere-se a distribuição do número de viagens, por zonas de tráfego, entre os diversos modos de transportes disponíveis para a população da área;

d) Escolha da rota: pode anteceder ou não a etapa de escolha do modo. Nesta etapa, são definidas as rotas utilizadas entre origens e destinos das viagens.

Combinam tanto dados desagregados como agregados. Geralmente, o modelo não funciona bem para os modos não-motorizados pelo fato destes modos terem amostra bastante reduzida (PORTER ET AL., 1999). 
Segundo Turner et al. (1997), devido à dificuldade de obtenção de dados, ainda prevalecem experiências no desenvolvimento de modelos de previsão de demanda cicloviária com informações agregadas. São mostradas, a seguir, algumas experiências desenvolvidas com o modelo tradicional de transportes.

- “Rhode Island Pre-ISTEA Study” (1982)

Desenvolvido no estado americano de Ilha de Rodes, considerado o menor estado americano, o "Rhode Island Pre-ISTEA Study" estimou a demanda cicloviária na ligação através de ciclovia/ciclofaixa entre as cidades de Providence e Bristol para o ano base (1980) e para o ano previsto (2000) utilizando medidas simplificadas em 3 das 4 etapas do modelo tradicional de transporte (a etapa de escolha modal não foi aplicada).

$\mathrm{Na}$ primeira etapa, referente à geração de viagens, foi assumido que as viagens de bicicleta seriam geradas apenas das zonas de tráfegos inseridas em um raio de $0,8 \mathrm{~km}$ distante da proposta de ciclovia/ciclofaixa a ser construída. Segundo os autores, a zona de influência assumida foi baseada em típicas distâncias percorridas até o transporte público e foram utilizadas as equações desenvolvidas em Harrisburg, Pennsylvania (1981) mostradas na Tabela 2.1 (TURNER ET AL., 1997)

Tabela 2.1 - Equações de geração de viagens (TURNER ET AL., 1997)

\begin{tabular}{|c|c|c|}
\hline $\begin{array}{l}\text { Tipo de } \\
\text { viagem }\end{array}$ & Motivos de viagem & Média diária estimada de viagens de bicicleta \\
\hline \multirow{3}{*}{ 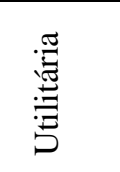 } & Para o trabalho & 4,9 por 1.000 empregados \\
\hline & Para a escola & 20,3 por 1.000 matrículas \\
\hline & Assuntos pessoais & 11,5 por 1.000 habitantes \\
\hline \multirow{4}{*}{ 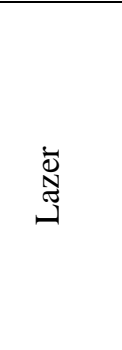 } & $\begin{array}{l}\text { Para recreação na } \\
\text { ciclovia/ciclofaixa }\end{array}$ & 19,1 por 1.000 habitantes \\
\hline & Visitar amigos & 22,4 por 1.000 habitantes \\
\hline & Recreação na vizinhança & 57,3 por 1.000 habitantes \\
\hline & $\begin{array}{l}\text { Recreação de longa } \\
\text { distância }\end{array}$ & 2,6 por 1.000 habitantes \\
\hline
\end{tabular}

As somatórias das viagens utilitárias e de lazer resultam no total de viagens de bicicleta dentro da zona de influência de 0,8 km. Dados socioeconômicos de 1980 e projeções 
para o ano de 2000 foram ajustadas a partir do Censo de 1980 e aplicadas na geração do total de viagens de bicicleta para cada zona analisada.

Na etapa seguinte, de distribuição de viagens, assumiu-se que $25 \%$ das viagens geradas de bicicleta dentro da zona de influência foram distribuídos ao longo da ciclovia/ciclofaixa construída. Em alguns casos, o número de viagens de bicicletas foi ajustado aos fatores locais como, por exemplo, áreas com alto uso de viagens de lazer que receberam maior percentual de viagens de bicicleta.

$\mathrm{Na}$ etapa de escolha da rota foi adotado o valor médio de comprimento de viagem igual a $4,8 \mathrm{~km}$ e, em cada zona, $50 \%$ ia para o norte e $50 \%$ para a direção sul. Nota-se que este comprimento de viagem adotado excedia o valor de $0,8 \mathrm{~km}$ utilizado na etapa de geração de viagens. Os volumes, em diversas seções no local onde a infraestrutura seria construída, compreendiam valores entre 200 e 400 bicicletas por dia entre as projeções de 1980 e 2000 . Em 1991 foram realizadas algumas contagens volumétricas em pontos ao longo da infraestrutura cicloviária construída e detectou-se que já havia valores superiores ao projetado para o ano de 2000.

O fato de considerar equações de geração de viagens por bicicleta de outra localidade e serem adotados valores, tanto na etapa de distribuição de viagens quanto para escolha da rota, podem ter influenciado o resultado do modelo. Neste caso, o ideal seria a calibração dos modelos de estimativa da demanda cicloviária baseado em informações da própria localidade.

- “LDS - Latent Demand Score” (Landis e Toole, 1996)

O modelo LDS consiste nas etapas de geração e distribuição de viagens do modelo tradicional de quatro etapas de transportes. Resumidamente, o modelo busca identificar os polos geradores de viagens por bicicleta e estabelecer sua área de influência, mapear os polos detectados com o uso de softwares de SIG e classificar cada segmento de via de acordo com a proximidade dos polos geradores de viagens por bicicleta. Ou seja, a partir do resultado para cada segmento de via, é possível determinar prioritariamente as vias que receberiam melhoria ou a implantação de infraestrutura de apoio ao uso da bicicleta. 
A expressão matemática do modelo LDS seria:

$$
L D S=\sum_{n=1}^{4}\left[T T S_{n} x \frac{\sum_{n=1}^{4}\left(G A_{n} \times \overline{T G_{n}}\right)}{\left(G A_{n} \times \overline{T G_{n}}\right)} x\left[\overline{T G_{n}} \sum_{d=1}^{l} P_{n d} \times g a_{n}\right]\right]
$$

Em que:

$\mathrm{n}=$ motivo de viagem por bicicleta (trabalho, escola, lazer e pessoal/negócios);

TTS $=$ percentual das viagens, por motivo, dentro do total de viagens por bicicleta;

$\mathrm{GA}=$ número de viagens produzidas ou atraídas, por motivo, dentro do total de viagens por bicicleta;

$\overline{T G}=$ geração média de viagens dos polos geradores;

$P=$ efeito da distância na realização da viagem (expresso em probabilidade);

$d=$ área de abrangência definida pela distância a partir dos polos geradores;

$g a=$ número de polos geradores dentro da área de abrangência (d);

$l=$ distância máxima de viagem a partir do polo gerador.

Assim, o LDS utiliza um modelo gravitacional probabilístico para hierarquizar os segmentos viários, baseados na proximidade dos mesmos até os polos de atratividade e a probabilidade de que a população irá usar a bicicleta para realizar as viagens considerando uma determinada distância. Segmentos com maior valor da demanda latente (LDS) deverão ter maior prioridade para financiamentos futuros.

O LDS pode ser combinado com medidas de nível de serviço para infraestruturas já existentes, para indicar quais delas têm maior necessidade de melhoria. Nesse caso, os segmentos mais críticos são os que apresentam baixo nível de serviço e maior demanda potencial.

Os passos para funcionamento do modelo são:

1) Estabelecer os polos de atração e de produção de viagens por bicicleta para viagens ao trabalho, escola, compras e lazer;

2) Mapear/Geocodificar os polos de atração e de produção e identificar os segmentos de via afetados por eles dentro de uma determinada distância; 
3) Determinar a geração de viagens dos polos e multiplicar pelo valor percentual de cada motivo de viagem específico (trabalho, escola, compras e lazer). O passo resultará no valor relativo do número de viagens produzidas ou atraídas;

4) Calcular a soma da probabilidade da realização da viagem, calibrando o resultado do passo anterior pelo fator de impedância (probabilidade x distância) para cada tipo de viagem e multiplicando pelo número de geradores. Somar os valores por segmento para cada tipo de viagem;

5) Multiplicar a probabilidade de realização da viagem (passo 4) pelo número relativo de viagens (passo 3). O valor resultante será o número de viagens de bicicletas para cada tipo de viagem;

6) Obter o Latent Demand Score (LDS) somando o número de viagens para os tipos de viagem estudados, chegando a um total para cada segmento de via. $\mathrm{O}$ valor total do LDS de cada via será então combinado com o seu respectivo nível de serviço, permitindo assim, uma análise de prioridade entre as vias.

O estudo permite ao planejador de transporte decidir em implantar ou não a infraestrutura cicloviária em um determinado segmento de via, no entanto, outros fatores não considerados na formulação do LDS podem influenciar também no uso maior da bicicleta na área em análise. Tais fatores incluem as características socioeconômicas da população no entorno do segmento de via. Neste caso seria necessário investigar de que forma, e quantificar, os fatores como renda domiciliar, sexo, idade, posse de automóveis, posse de bicicletas, setor de atividade no qual o indivíduo está inserido, entre outros, influenciariam o uso da bicicleta. A análise conjunta do LDS e destes fatores poderia ser de grande valia ao responsável pela gestão urbana da área.

\section{(ii) Modelos baseados em taxas de viagens:}

Segundo An e Chen (2007), esta categoria utiliza dados agregados em uma determinada área para estimar as taxas de viagens por modos não-motorizados. Geralmente, as taxas são em função dos motivos de viagens (por exemplo, pessoas que vão ao trabalho) e são identificados fatores socioeconômicos correlacionados como idade, se estudante ou não, sexo, entre outros. 
Um exemplo de modelo baseado em taxas de viagens foi o estudo de integração entre bicicleta e ônibus, desenvolvido pela agência de transportes do estado da Flórida, no distrito de Dade County para definição de quais rotas de transporte público receberiam a implantação de infraestrutura de apoio ao ciclista para incentivar a integração entre bicicleta e ônibus (TURNER ET AL., 1997). Neste caso, seriam implantados bicicletários ao longo do itinerário da linha de ônibus. A modelagem foi baseada na estimação adotada por Epperson et al. (1995) para áreas cobertas pelas linhas de transporte público considerando cada um dos três fatores a seguir:

1) Presença de grupos considerados de baixa renda;

2) Presença de pessoas com idade superior a 16 anos que reportaram no Censo norteamericano de 1990 que a bicicleta foi o modo principal utilizado para viagens ao trabalho;

3) Características demográficas da área baseada em informações da pesquisa NPTS Nationwide Personal Transportation Study (1990) e do Censo de 1990.

Em cada um dos fatores foi calculado o número de possíveis usuários de bicicleta por 1000 habitantes. No primeiro fator, o número médio variou entre 93 e 899 por 1000 habitantes. No segundo fator, o número de possíveis viajantes ciclistas foi, em média, igual a 31 por 1000 residentes. O terceiro fator utilizou médias de viagens de bicicleta para grupos de pessoas de acordo com sexo, raça e idade e o número variou entre 8 e 35 usuários de bicicleta por 1000 habitantes. Através da estimativa considerando as três taxas de demanda cicloviária em áreas cobertas pelo transporte público, foram definidas quais linhas receberiam melhorias para o maior uso da bicicleta.

O estudo de integração entre ônibus e bicicleta supõe que grupos de baixa renda e em idade economicamente ativa estão mais propensos a usar a integração entre ônibus e bicicleta. Tais características, como já dito, influem no uso maior da bicicleta como modo de transporte. No entanto, este estudo difere substancialmente do proposto pela Tese de Doutorado já que a infraestrutura cicloviária a ser considerada são as ciclovias e/ou ciclofaixas e não bicicletários como propôs o estudo.

Outro trabalho desenvolvido nesta categoria foi o proposto por Barnes e Krizek (2005). Segundo os autores, a estimativa do número de ciclistas em uma área poderia ser 
utilizada nas justificativas de custos provenientes de propostas políticas que incentivem o uso da bicicleta. Salienta-se que além do número de ciclistas, há os benefícios indiretos que a sociedade receberia pelo fato de mais pessoas estarem pedalando nas cidades como, por exemplo, a redução de gastos com saúde, de congestionamentos, de emissão de gases poluentes etc. Pode ser considerado como modelo de estimativa da demanda cicloviária simples, utilizado nos Estados Unidos, que pressupõe que uma fração das viagens diárias por bicicleta está relacionada a uma pequena fração de ciclistas que utilizam a bicicleta com maior frequência ao trabalho.

O modelo foi baseado em três pesquisas: Dados do Censo norte-americano de 2000 que detalha, por exemplo, a escolha do modo de transporte e apresenta percentuais de viagens a trabalho por bicicleta de aproximadamente $10 \%$ do total de residentes do EUA; Dados da contagem do NHTS (National Household Travel Survey), realizada em 2001 em 25.000 residências em 34 estados norte-americanos, que detalha o total de movimentos diários por bicicleta; Dados da contagem do TBI (Travel Behavior Inventory), que foi realizada em 2001 em 5.000 residências nas cidades de Minneapolis e Saint Paul, localizadas no estado norteamericano de Minnesota, que também continha os movimentos diários por bicicleta. Foram geradas três equações distintas, mostradas a seguir, em que todas tiveram uma das parcelas da equação referente aos dados do Censo de viagens por motivo trabalho realizadas por adultos.

1. Equação proveniente dos deslocamentos notados em 15 regiões metropolitanas dos EUA:

$$
\mathrm{A}=0,3 \%+1,5 \times \mathrm{C} \quad\left(\mathrm{R}^{2}=0,7\right)
$$

2. Equação proveniente dos deslocamentos diários em 34 estados norte-americanos:

$$
\mathrm{A}=0,4 \%+1,1 \times \mathrm{C} \quad\left(\mathrm{R}^{2}=0,3\right)
$$

3. Equação proveniente dos deslocamentos diários em 65 zonas das cidades de Minneapolis e Saint Paul:

$$
\mathrm{A}=0,6 \%+2,5 \times \mathrm{C} \quad\left(\mathrm{R}^{2}=0,3\right)
$$

Em que:

A: percentual de adultos que usam bicicleta diariamente e

C: percentual de viagens por motivo trabalho realizadas por adulto. 
O estudo concluiu que em um dia, aproximadamente, $1 \%$ dos adultos nos EUA andam de bicicleta em suas respectivas viagens. Em grandes áreas metropolitanas ou estados, esse número pode variar entre $0,3 \%$ e $2,5 \%$. Em áreas menores o percentual pode chegar a $15 \%$. As políticas públicas adotadas, em cada local, para implantação de infraestrutura de apoio ao ciclista podem justificar as diferenças percentuais notadas entre as áreas em análise, porém, não há como confirmar a hipótese, pois as equações geradas não consideram a implantação ou a melhoria através de variáveis que representem a infraestrutura de apoio ao ciclista.

O estudo de Barnes e Krizek (2005) baseado em informações agregadas que serviram para construção de equações que determinavam o percentual de adultos que usam a bicicleta diariamente em uma região metropolitana, estado ou cidade, impossibilita a análise mais específica da implantação da infraestrutura cicloviária, no caso ciclovias e/ou ciclofaixas, em uma determinada via. Por exemplo, não seria possível quantificar o fluxo de ciclistas na infraestrutura cicloviária. Além disso, o estudo não leva em conta outras características que influem no uso da bicicleta, como renda, posse de veículos motorizados e bicicleta, idade, entre outros.

Outro trabalho na linha de modelos que consideram taxas de viagens foi $o$ desenvolvido para as cidades de Dallas e Fort Worth com o intuito de identificar zonas de tráfego com alto uso da bicicleta e que, possivelmente, necessitariam de infraestrutura cicloviária (INSTITUTO DE TRANSPORTES DO TEXAS, 1997). Foi calculado um indicador cicloviário que considera a somatória de cinco fatores distintos e que possuem pesos diferenciados de acordo com a Tabela 2.2.

Os autores desenvolveram os pesos de acordo com a importância em relação ao uso da bicicleta. Quanto maior a soma, maior a necessidade de implantação de infraestrutura cicloviária na zona de tráfego em análise. 
Tabela 2.2 - Fatores utilizados no cálculo do indicador cicloviário (NCTCG’s, 1996)

\begin{tabular}{c|c|c}
\hline Fator & Característica do Fator & Peso \\
\hline Distância de viagem & $\begin{array}{c}\text { Alta porcentagem do total de } \\
\text { viagens estão abaixo de } 8 \mathrm{~km}\end{array}$ & 3.0 \\
\hline Uso do solo & $\begin{array}{c}\text { Alta porcentagem do uso do solo } \\
\text { com oferta de empregos }\end{array}$ & 2.0 \\
\hline Renda domiciliar média & Baixa renda domiciliar média & 2.0 \\
\hline Densidade populacional & Alta densidade populacional & 1.0 \\
\hline Densidade de empregos & Alta densidade de empregos & 1.0 \\
\hline
\end{tabular}

Pessoas empregadas em atividades relacionadas, por exemplo, ao setor da construção civil, podem estar mais propensas ao uso da bicicleta. Neste caso, o indicador considerado no estudo não difere os diversos tipos de emprego e seus respectivos pesos na escolha do modo cicloviário nas zonas de tráfego em análise. Além disso, fatores geográficos como clima e relevo não foram considerados na construção do indicador.

\section{(iii) Modelos comportamentais:}

Segundo Porter et al. (1999), são mais sofisticados e, por isso, requerem conhecimento técnico para desenvolvimento e aplicação em áreas. Os modelos estimam a decisão feita individualmente, por exemplo, para a escolha do modo ou da rota como função de variáveis que podem incluir fatores socioeconômicos, de uso e ocupação do solo e aspectos que descrevem as facilidades implementadas, entre outras. Neste caso, modelos de escolha discreta são largamente utilizados tanto para resolver problemas relacionados à escolha do modo quanto para a escolha da rota.

Baseiam-se no comportamento observado quando derivam de pesquisas de viagem onde os respondentes relatam os padrões de viagem feitos anteriormente ou em pesquisas de "escolha hipotética", ou de preferência declarada, em que os entrevistados escolhem o modo entre alternativas de viagem com diferentes características. Por ser de foco individual, os modelos diferem fundamentalmente dos modelos em nível agregado, que estimam a probabilidade de escolha do modo em função das características médias de população das zonas de tráfego ou de regiões. 


\subsubsection{Contextualização da Tese de Doutorado na literatura existente}

A Tese de Doutorado ora desenvolvida está incluída na categoria de modelos comportamentais. A demanda cicloviária será estimada a partir de informações socioeconômicas e de viagens de uma determinada população provenientes de pesquisa Origem/Destino. Além disso, outra fonte de dados conterá as informações sobre a infraestrutura implementada ao modo cicloviário (ciclovias e ciclofaixas) na área urbana em estudo.

Ryley (2006) afirma que há 2 tipos de modelos de escolha discreta baseados na demanda cicloviária: modelos de escolha de rota e de escolha do modo. Há uma variedade de estudos que estimam a demanda utilizando modelos logit desagregados baseados em pesquisa de preferência declarada, principalmente, em relação à escolha da rota. Os estudos têm mostrado que o tempo e a segurança são os grandes determinantes na escolha da rota pelos ciclistas. Com relação à escolha do modo, poucos estudos têm procurado modelar a demanda cicloviária com dados de preferência declarada. A dificuldade surge devido ao fato de que o uso da bicicleta é feito por uma minoria da população e, portanto, necessita de pesquisas extensivas com amostra grande.

Portanto, a base de dados onde há grande volume de informações com dados de viagem de ciclistas pode ser de grande utilidade para o entendimento da demanda cicloviária. Neste trabalho, cujo objetivo é buscar a influência da implementação da infraestrutura cicloviária e de outros fatores socioeconômicos que afetam o uso da bicicleta, é necessário que a Pesquisa O/D disponível tenha percentual considerável de ciclistas na amostra.

Como já dito, o uso de técnicas de modelagem desagregadas para explorar a escolha do modo e da rota relacionada ao transporte cicloviário vêm sendo utilizadas nas últimas décadas (BOVY E BRADLEY, 1985; HOPKINSON E WARDMAN, 1996; WARDMAN et al., 1997; ORTÚZAR et al., 2000; STINSON E BHAT, 2003; MOUDON et al., 2005; PLAUT, 2005; TILAHUN et al., 2007; WARDMAN et al., 2007). Estes estudos têm revelado um conjunto de variáveis relevantes ao uso da bicicleta relacionadas com características socioeconômicas, geográficas e de transportes. Sendo que as duas últimas características (geográficas e de transportes) estão fortemente ligadas ao tempo de viagem e à segurança da pessoa ao optar pela utilização de bicicleta. 
As variáveis socioeconômicas relevantes nos estudos foram: idade, sexo, posse de automóveis, renda, grau de instrução, total de moradores no domicílio, situação familiar, tipo de emprego, nível de experiência em ciclismo e condicionamento físico. As variáveis geográficas incluem: distâncias de viagem, localização das residências (urbanas x rural), variáveis climáticas (relacionadas à chuva, vento e temperaturas) e tipo de sinalização viária na área (se há orientação aos demais modos de transporte sobre a presença de ciclistas na área). Já as variáveis de transportes dizem respeito ao tipo de infraestrutura cicloviária, facilidades no destino das viagens como bicicletários, vestiários, armários etc., e características das demais alternativas de modo de transporte disponíveis à população (particular, público, a pé e outros).

Diferentes medidas de encorajamento ao uso da bicicleta (tais como: rotas completamente desagregadas, pagamento diário para ir ao trabalho de bicicleta e facilidades no destino final, como estacionamento e vestiário) podem potencializar a demanda cicloviária. Quando todas as medidas favoráveis ao uso da bicicleta, para viagens ao trabalho, são consideradas num modelo de escolha discreta para estimar probabilidades das alternativas de modo de viagem, pode ser notado um aumento na demanda cicloviária em comparação com as alternativas que não tinham previsão de investimentos ao modo cicloviário. Isto sugere que, caso haja intenção de aumentar o uso de modos não-motorizados, seria promissora a implantação de tais medidas na área (WARDMAN et al., 2007).

Katz (1995) comenta que, no modo cicloviário, a distribuição dos percentuais de motivos de viagem (viagens a trabalho, lazer, compras, entre outros) em relação ao total de viagens pode ser diferente da distribuição existente nos demais modos de transportes. A existência de muitas pessoas que utilizam a bicicleta para viagens de lazer, podendo estas viagens serem longas e em horários diferentes dos períodos de pico, sugere uma análise subjacente às abordagens mais tradicionais, com intuito de compreender melhor as características intrínsecas deste modo, com auxílio de sistemas inteligentes de transporte e de sistemas de informações geográficas voltados para o modo cicloviário.

Segundo Pucher et al. (1999), os Estados Unidos é um exemplo de lugar onde a bicicleta pode ser considerada uma ferramenta de recreação e o seu uso não pode ser considerado derivado da demanda por atividades. Já o contrário é válido para países com alto 
percentual de uso da bicicleta, como em alguns países da Europa, em que a bicicleta é tratada de forma igualitária com os demais modos disponíveis para a população.

Além do motivo da viagem, a análise de grupos de pessoas homogêneos, ou seja, com mesmas características socioeconômicas, sujeitas à diversos ambientes geográficos, pode propocionar percentuais diferenciados de uso da bicicleta.

Kepperman e Timmermans (2009), com intuito de capturar os atributos geográficos e socioeconômicos na propensão do uso dos modos à pé e de bicicleta na Holanda, utilizaram o algoritmo CHAID para relacionar aspectos sócio-demográficos e físicos com as características de 4 grupos homogêneos de pessoas (usuários de carro, ciclistas, caminhantes e inativos). Os resultados mostraram que a participação nos diversos modos depende, primeiramente, da idade. Os idosos (>72 anos) são mais inativos que os respondentes jovens e, consequentemente, usam menos a bicicleta. O grau de instrução (GI) também se mostrou importante e os entrevistados com GI mais baixo são mais frequentemente inativos do que os que possuem GI médio ou alto. Além disso, os graduados e pós-graduados têm maior propensão para o uso do carro, diferentemente dos técnicos de nível médio, que são mais propensos a utilizar a caminhada e a bicicleta para chegar ao destino. A influência do ambiente físico, tomada a partir da escala de densidade demográfica que ia de fortemente urbanizada até pouco urbanizada, foi significante para todos os respondentes jovens. Altos níveis de urbanização são significamente relacionados a uma grande porcentagem de caminhantes e também de inativos. Ao contrário, o segmento de ciclistas foi mais presente em áreas de baixa urbanização, assim como, os usuários do carro.

Hunt e Abraham (2007) desenvolveram uma simulação do comportamento de ciclistas em Edmonton, Canadá, em que vários aspectos que poderiam influenciar o uso da bicicleta foram testados através do modelo logit de escolha modal. A cidade é o principal centro metropolitano da Província de Alberta e disponibilizava para uso cerca de $47 \mathrm{~km}$ de ciclovias, $3 \mathrm{~km}$ de ciclofaixas e $96 \mathrm{~km}$ de rotas identificadas com a presença de bicicletas em compartilhamento com veículos motorizados.

Num estudo de preferência declarada foram entrevistados 1128 ciclistas que analisaram facilidades a serem implantadas para viagens ao trabalho ou recreação. Por exemplo, foram consideradas as implantações de dois tipos de infraestrutura cicloviária, a 
saber: ter ou não ter vestiários no destino final; e ter ou não ter estacionamento seguro. Também foram coletadas informações sobre características socioeconômicas (sexo, idade e renda domiciliar), níveis de experiência dos ciclistas e simulado o comportamento dos ciclistas entre opções de rotas considerando o tráfego compartilhado com veículos motorizados, em ciclovias ou ciclofaixas. As variáveis foram especificadas em termos de tempo, por exemplo, caso esteja disponível vestiário no destino final haveria um acréscimo no tempo de viagem e o ciclista responderia se preferiria ou não ter o acréscimo para dispor do vestiário. Os resultados principais através do modelo logit mostraram que o tempo gasto no tráfego compartilhado é mais oneroso que o tempo gasto em ciclovias ou ciclofaixas, que o estacionamento seguro é mais importante que vestiários no destino final e que, com o aumento do nível de experiência do ciclista, o tempo de viagem em vias de tráfego compartilhado tende a ser menos oneroso.

Ortúzar et al. (2000) desenvolveram um experimento na cidade de Santiago do Chile que previu entrevista domiciliar com potenciais usuários de bicicleta. Foram visitados 1744 domicílios e 851 pessoas entrevistadas. O questionário foi baseado nos itens a seguir:

- Caracterização socioeconômica do domicílio através de informações sobre o número de pessoas residentes, número de bicicletas, número de carros e renda familiar (classificação em renda alta, média-alta, média, média-baixa, baixa, extremamente baixa);

- Identificação da pessoa entrevistada através da ocupação principal, se possui licença para dirigir, frequência de uso da bicicleta, principal motivo nas viagens feitas por bicicleta, sexo, idade e grau de instrução;

- Identificação das viagens feitas no dia anterior por pessoas acima de 14 anos de idade em que foram coletadas as informações sobre os motivos das viagens, modos utilizados, origem e destino;

- Apresentação ao entrevistado, através de mapas, de um cenário futuro para a cidade de Santiago, em que era prevista a expansão das linhas de Metrô, mais redes de ônibus segregadas e a inclusão de vias para uso da bicicleta; 
- Separação dos potenciais usuários da bicicleta dos que não consideram uma boa ideia o uso da bicicleta. As perguntas, feitas para os entrevistados que não utilizaram a bicicleta, diziam respeito aos motivos para não terem utilizado e, se fosse possível, se gostariam de usar a bicicleta nos seus deslocamentos;

- Seleção de uma viagem das pessoas identificadas como potenciais usuários de bicicleta para desenvolvimento de um experimento de preferência declarada. Inicialmente, era escolhida a viagem feita através de automóvel e, em sequência, por ônibus, metrô ou outros modos. O experimento continha perguntas que almejavam opiniões sobre o clima, tipo de infraestrutura cicloviária (ciclovia ou ciclofaixa), tempo de viagem e custo de modos motorizados.

Foi estimado um modelo logit binário em que a variável dependente era se a pessoa pertencia ou não ao grupo de potenciais usuários da bicicleta. As variáveis independentes foram todas do tipo dummy, exceto os itens c) e d), mostrados a seguir:

a) Acessibilidade ao Metrô: localização da residência com acesso direto ou não ao Metrô ou Trem;

b) Localização do usuário: se em zona periférica da cidade ou não;

c) Número de bicicletas dividido pelo número de membros da residência;

d) Número de carros na residência;

e) Renda familiar: se baixa ou não;

f) Sexo masculino ou não;

g) Idade compreendida entre 14 e 30 anos ou não;

h) Idade acima de 50 anos ou não;

i) Nível de formação: universitária, técnica ou outras;

j) Usuário da bicicleta ao menos uma vez por mês ou mais;

k) Motivo da viagem: se trabalho ou não; e se estudo ou não;

1) Condição do entrevistado: se passageiro de carro ou não, se pedestre ou não, se ciclista ou não;

m) Duração das viagens: se longas ou não. 
Variáveis como baixa renda, pessoa do sexo masculino e jovem, número de bicicletas no domicílio dividido pelo número de membros na residência, usuário da bicicleta pelo menos uma vez por mês ou mais, foram estatisticamente significativas e contribuíram positivamente segundo o resultado do modelo logit binário.

Akar e Clifton (2009) desenvolveram um questionário, disponibilizado na internet para a comunidade universitária da Universidade de Maryland (College Park), nos Estados Unidos, com o objetivo de entender os padrões de viagens e assuntos específicos que dizem respeito aos ciclistas como, por exemplo, possíveis melhorias em infraestrutura cicloviária e políticas e programas de incentivo ao uso da bicicleta. Tanto os não-ciclistas como os ciclistas concordaram que ciclovias e ciclofaixas encorajariam o uso do modo no campus. Modelos de escolha discreta foram estimados para os viajantes do campus e, como resultado, notou-se que as pessoas usuárias de modos não-motorizados são mais sensíveis ao tempo de viagem do que aquelas que utilizam modos motorizados. Além disso, as mulheres utilizam menos a bicicleta do que os homens. Vale ressaltar que os indivíduos que perceberam a caminhada e o ciclismo como formas de se exercitarem e também que identificam a flexibilidade de horários de partida como um importante fator na escolha do modo de viagem, foram os maiores adeptos ao uso da bicicleta.

Investimentos em infraestrutura cicloviária, como ciclovias e ciclofaixas, podem gerar o aumento de taxas de uso de bicicleta pois o risco de acidentes e o tempo de viagem é reduzido. Em muitos países da Europa o planejamento e a organização da infraestrutura cicloviária foram e são fundamentais para encorajar o uso frequente da bicicleta em deslocamentos urbanos. Segundo Pucher e Buehler (2008), há mais de 40 anos, a Alemanha, Holanda e Dinamarca constroem tais infraestruturas e, desta forma, mantém altos índices de uso da bicicleta.

Vale ressaltar que o sucesso não é somente devido à implantação de infraestrutura cicloviária pois outras medidas como, por exemplo, a restrição de uso dos carros em centros urbanos também contribuíram para o aumento do uso da bicicleta em cidades da Europa.

Nelson e Allen (1997), baseado em uma amostra de 18 pequenas e grandes cidades norte-americanas, concluíram que a construção de 1 milha adicional (aproximadamente igual 
a $1,6 \mathrm{~km}$ ) de ciclovias e/ou ciclofaixas por 100.000 residentes, conduz a um incremento associado de $0,0069 \%$ de viajantes ciclistas para o trabalho.

Já Dill e Carr (2003), utilizando informações de 43 grandes cidades norte-americanas, notaram que a cada milha linear adicional de faixas para bicicletas por milha quadrada de área da cidade, há associado um incremento de aproximadamente $1 \%$ nos padrões de viagens de bicicleta.

Hopkinson e Wardman (1996) afirmam que há um grande número de variáveis que influenciam a escolha do modo de viagem e isto cria dificuldades em obter estimativas satisfatórias de demanda em infraestruturas implantadas ao modo cicloviário. Aliado a isto, há o fato de que a demanda cicloviária quase sempre é menor do que a demanda por outros modos de viagem (automóveis, ônibus, metrô etc.). Segundo os autores, ao avaliar a implantação de ciclovia entre duas cidades britânicas juntamente com melhoria de duas rotas já existentes para modos motorizados, através da elaboração de experimento de preferência declarada com auxílio de modelo de escolha discreta, a ciclovia teve impacto menor na escolha em comparação com variáveis que representavam as melhorias das rotas para modos motorizados. Um dos motivos seria a parcela pequena de usuários da bicicleta em comparação com a demanda por modos motorizados.

É possível notar que além da dificuldade de obtenção de dados sobre a demanda cicloviária em áreas urbanas visto que, na maioria das cidades, o uso da bicicleta ainda é incipiente e em muitos casos têm como motivo o lazer, os estudos não contemplam informações sobre mudanças que, por ventura, possam ter surgido concomitantemente com a implantação da infraestrutura cicloviária.

Estudos que analisem os percentuais de uso da bicicleta antes e depois da implantação da infraestrutura cicloviária não são comuns em virtude da falta de dados que permitam a comparação. Talvez seja devido ao fato de que os responsáveis pela gestão urbana, geralmente, estão interessados em implantar a infraestrutura e não em fazer o acompanhamento da demanda cicloviária após a implantação. Não há também estudos que considerem os aspectos regionais de mudanças que, por exemplo, possam surgir em virtude do aquecimento em algum setor da economia. 
Neste contexto, o experimento desta Tese de Doutorado buscará levar em conta as variáveis citadas nesta revisão que foram importantes ao uso da bicicleta (incluindo a infraestrutura cicloviária implantada), considerar as mudanças na economia que possam ter surgido e, além disso, verificar a possibilidade da utilização destas variáveis na avaliação e no planejamento de infraestrutura de apoio aos ciclistas em áreas urbanas. Vale salientar que a técnica a ser utilizada (modelo de escolha discreta) já é largamente utilizada em trabalhos que envolvem a estimativa da demanda cicloviária. 


\section{CAPÍTULO 3}

\section{DETALHAMENTO DO MÉTODO}

แ

\subsection{Considerações Iniciais}

As hipóteses do trabalho, de que é possível identificar e quantificar os fatores que influem no uso de bicicletas e de que estes fatores podem ser usados para avaliar e planejar a implantação de ciclovias e/ou ciclofaixas em uma área urbana, serão testadas e verificadas segundo o método proposto neste capítulo.

A síntese do método a ser utilizado, para atingir as finalidades propostas neste trabalho, está mostrada no fluxograma presente na Figura 3.1. Inicialmente, consistirá da apresentação dos dados necessários para realizar a pesquisa. Salienta-se que a área urbana a ser estudada deverá estar dotada de infraestrutura cicloviária disponível para a população e também deverá, idealmente, possuir contagens de fluxo de bicicletas realizadas antes e depois da implantação de ciclovias e/ou ciclofaixas. Juntamente com informações socioeconômicas da população urbana, seriam os dados desejáveis para a realização do trabalho.

No entanto, devido ao fato de que a região de interesse, desta Tese, dispõe apenas dos dados de contagens realizadas antes da implantação de ciclovias e/ou ciclofaixas e não depois dela, foi necessário utilizar a Pesquisa Origem/Destino, realizada após a implantação das ciclovias e/ou ciclofaixas para, através dela, obter o número de viagens que passam por um 
determinado ponto de contagem. Assim, a Pesquisa O/D será basicamente utilizada para estimar o fluxo de ciclistas após a implantação das ciclovias e/ou ciclofaixas.

Desta forma, os dados disponíveis serão o Plano Cicloviário Metropolitano da Região Metropolitana da Baixada Santista (PCM/RMBS), que dispunha de pontos de contagem volumétrica de ciclistas antes da implantação de infraestrutura cicloviária, e a Pesquisa Origem/Destino da RMBS que, inicialmente, poderá estimar o número de viagens de bicicleta que passam pelos mesmos pontos de contagem de ciclistas através da seleção das viagens multiplicadas pelo respectivo fator de expansão do par O/D.

Posteriormente, segundo o fluxograma, haverá a caracterização da infraestrutura cicloviária existente, através de informações sobre ciclovias e/ou ciclofaixas implantadas na RMBS, socioeconômica e de viagens urbanas, que serão obtidas através de dados oriundos da Pesquisa O/D da RMBS.

As caracterizações servirão para estimar um modelo de escolha discreta, que poderá avaliar, tanto qualitativa quanto quantitativamente, fatores que influem no uso da bicicleta e que poderá servir para o planejamento de vias para o uso exclusivo de ciclistas. Para tanto, serão avaliados 2 cenários:

- Cenário 1 (ano 2007): será calculado o número de viagens de bicicletas que passam pelos pontos de contagem através do modelo estimado de escolha discreta. Estes números serão comparados com as viagens de bicicleta, obtidas diretamente da $\mathrm{O} / \mathrm{D}$, e que passam pelos mesmos pontos de contagem. Caso o modelo reproduza o volume adequadamente, será avaliado um novo cenário, caso contrário, serão feitas novas caracterizações;

- Cenário 2 (ano 2006): será recriado o cenário de 2006, ano em que foi realizado o PCM, através de modificações que puderam ser notadas em variáveis socioeconômicas e de infraestrutura cicloviária, e calculado novamente o número de viagens de bicicleta nos pontos preestabelecidos através do modelo de escolha discreta estimado. Posteriormente, os resultados serão comparados com os valores da contagem volumétrica de ciclistas, contidas no PCM, e caso o modelo reproduza adequadamente 
o número de viagens nos pontos para o ano de 2006, as hipóteses deste trabalho estarão satisfeitas e, em caso contrário, a segunda hipótese será refutada.

Dados Disponíveis
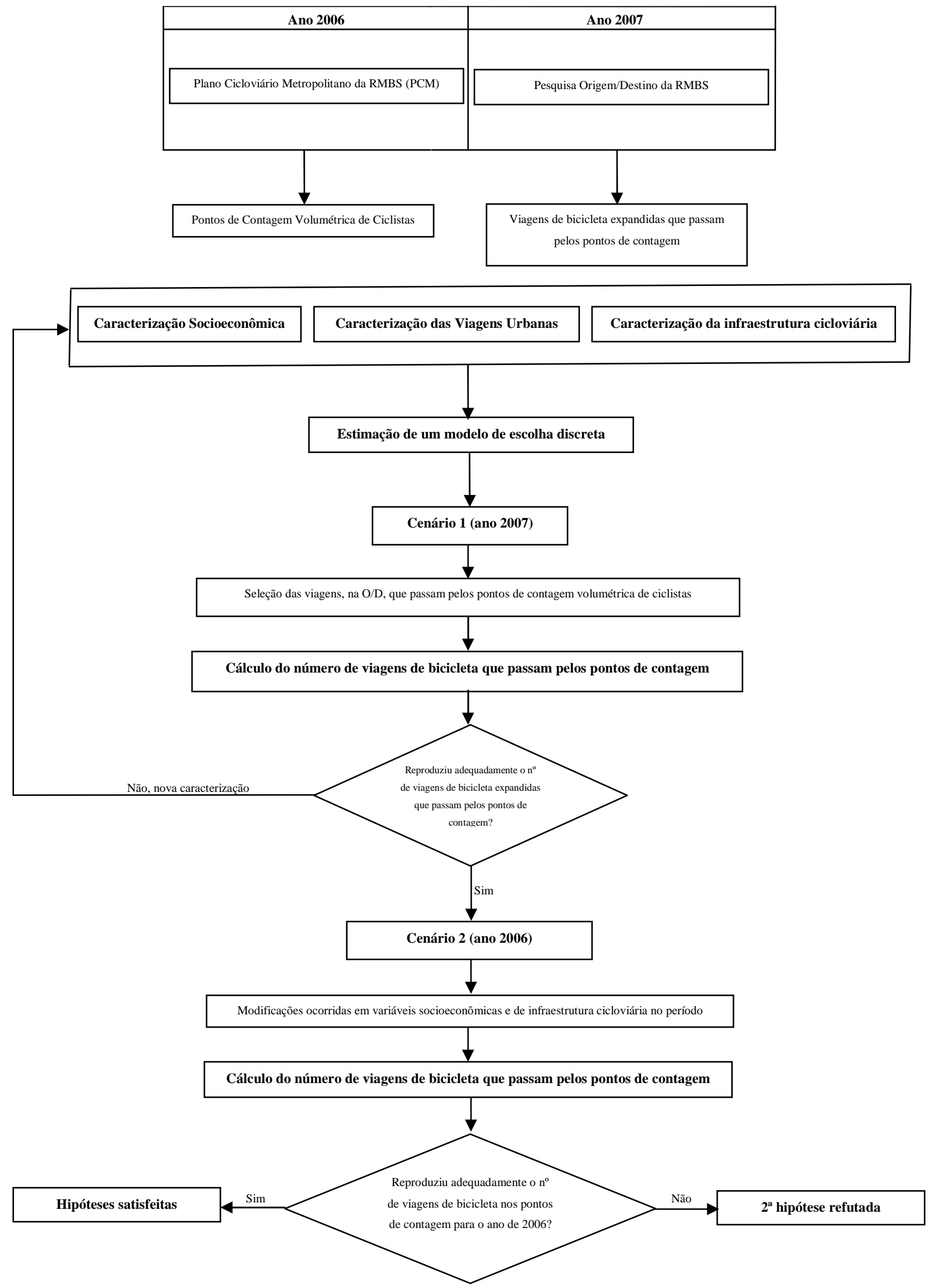

Figura 3.1 - Fluxograma do detalhamento do método utilizado 


\subsection{Dados Disponíveis}

Com o intuito de identificar e quantificar os fatores que influem no uso de bicicletas e de que estes fatores podem ser usados para avaliar e planejar a implantação de ciclovias e/ou ciclofaixas, optou-se em procurar cidades ou regiões metropolitanas que possuíam rede viária com a presença de ciclovias e/ou ciclofaixas, únicos tipos de infraestrutura de apoio ao ciclista consideradas no trabalho, e que disponibilizavam contagens volumétricas de ciclistas antes e depois da implantação de infraestrutura cicloviária.

Através de contato com a Secretaria dos Transportes Metropolitanos do Estado de São Paulo-STM/SP e posterior envio de solicitação de cessão de dados, foi disponibilizado para uso da EESC/USP a “1 ${ }^{a}$ Pesquisa O/D da RMBS-Região Metropolitana da Baixada Santista”, realizada no período compreendido entre agosto de 2007 e abril de 2008, já que a região é reconhecida pelo uso da bicicleta pela população em seus deslocamentos diários e pela quantidade considerável de ciclovias e/ou ciclofaixas construídas.

Além da Pesquisa O/D, a RMBS dispunha de um Plano Cicloviário Metropolitano (PCM), desenvolvido pela Agência Metropolitana da Baixada Santista-AGEM e concluído em dezembro de 2006, com a situação das ciclovias e/ou ciclofaixas construídas e a previsão de construções para os próximos 5, 10 e 20 anos, respectivamente.

No anexo do PCM (2006) havia também informações sobre contagens volumétricas de ciclistas em pontos que estavam espalhados pelos 9 municípios da RMBS, a saber: PeruíbeSP, Mongaguá-SP, Itanhaém-SP, Praia Grande-SP, São Vicente-SP, Santos-SP, Cubatão-SP, Guarujá-SP e Bertioga-SP.

Para que se tornassem comparáveis os dados resultantes de pesquisa $\mathrm{O} / \mathrm{D}$ e de contagem volumétrica de ciclistas, será adotado o intervalo de 1 hora. Este intervalo será considerado para seleção das viagens da $\mathrm{O} / \mathrm{D}$, que passam pelos pontos de contagem, e para expansão das contagens volumétricas de ciclistas que duram 10 minutos, feitas durante a elaboração do PCM.

As viagens resultantes de pares $\mathrm{O} / \mathrm{D}$ que, provavelmente, utilizam as rotas onde os pontos de contagem estavam localizados, serão expandidas pela multiplicação de cada viagem 
pelo respectivo fator de expansão. Salienta-se que o fator de expansão será obtido através dos seguintes passos:

1 - A partir dos dados da Pesquisa O/D, obter matriz O/D diária (1);

2 - De posse da matriz O/D diária (2), fornecida pela STM, obter o fator de expansão (3) para cada par O/D a partir da divisão de (2) por (1).

Destaca-se que a partir da Pesquisa O/D vai ser possível determinar o número de viagens de bicicleta expandidas que passam pelos pontos de contagem volumétrica de ciclistas. Novamente, o ideal seria que a comparação fosse feita utilizando as duas contagens volumétricas de ciclistas, porém, como não foram realizadas contagens após a implantação de ciclovias e/ou ciclofaixas na RMBS, o uso dos dados da Pesquisa O/D foi o expediente adotado para contornar o problema.

\subsection{Caracterização Socioeconômica, das Viagens Urbanas e da Infraestrutura Cicloviária}

As informações disponíveis para a RMBS, através da amostra entrevistada da população na Pesquisa O/D, permitem que seja possível caracterizar as viagens urbanas e os dados socioeconômicos. Já as características de infraestrutura cicloviária podem ser obtidas através de dados do PCM sobre a situação das ciclovias e/ou ciclofaixas construídas na RMBS. Além disso, no PCM havia também pontos identificados de contagem volumétrica de ciclistas onde, anteriormente, não havia ciclovia e nem ciclofaixa implantada.

Para caracterização das condições socioeconômicas dos viajantes, obtida da Pesquisa O/D, serão utilizadas variáveis socioeconômicas domiciliares, tais como: número de automóveis, número de bicicletas, número de motos e renda familiar; e individuais, tais como: idade, sexo, situação familiar, renda individual, se estuda ou não, grau de instrução, se trabalha ou não, setor de atividade em que trabalha e vínculo empregatício, com intuito de saber de que forma tais características influenciam os usuários de bicicleta na RMBS.

Ressalta-se que, durante a preparação do experimento, as variáveis socioeconômicas, tanto domiciliares quanto individuais, deverão ser tratadas para que seja possível a utilização das mesmas para a estimação de um modelo de escolha discreta. 
A caracterização das viagens urbanas deverá considerar a escolha do modo bicicleta isoladamente, ou seja, os modos não-motorizados à pé e bicicleta, opções consideradas no questionário da $\mathrm{O} / \mathrm{D}$ da $\mathrm{RMBS}$, não poderão ser agrupados durante a preparação do experimento. Os demais modos poderão ser agrupados, levando em conta, características intrínsecas relacionadas aos modos privado e público. Desta forma, durante a realização do experimento, serão consideradas 4 opções de escolha do modo de viagem: privado, público, bicicleta e à pé.

Outras características das viagens urbanas também devem ser consideradas como, por exemplo, o tempo reportado pelo viajante urbano, que poderá ser obtido através dos horários de início e fim das viagens; o tempo de espera para usuários do modo público; e os tempos de caminhada, tanto na origem como no destino, para chegar ao local onde a pessoa irá embarcar no modo de transporte.

Os tempos de caminhada serão somados ao tempo reportado pelo viajante, exceto para os indivíduos que declararam que utilizaram o modo à pé como principal, e o tempo de espera, para o modo público, será obtido através das informações de itinerário e frequência de linhas intermunicipais e intramunicipais existentes na RMBS. Desta forma, para cada linha, o intervalo médio de tempo, entre ônibus subsequentes, será atribuído nas zonas de tráfego por onde o ônibus passará. Após realizar este procedimento para todas as linhas, será calculado o tempo médio de espera para cada zona de tráfego e, em função da viagem ser inter ou intramunicipal, este tempo médio será somado ao tempo reportado pelo viajante urbano.

A distância de viagem será outra característica das viagens urbanas a ser utilizada neste trabalho. Como a pesquisa não foi georreferenciada, serão alocadas todas as viagens aos centróides das zonas de tráfego, informadas pelos viajantes urbanos no questionário da O/D, como origem e destino. Ou seja, estes centróides serão considerados como únicos pontos de começo e de fim de todas as viagens da RMBS. Para isso, pretende-se eliminar áreas verdes e zonas de tráfego onde não havia presença de construções com base em imagens da época disponibilizada pelo software Google Earth, e construir a rede viária existente na RMBS.

Ressalta-se que, a partir do mapa também disponibilizado pela AGEM da RMBS, que dispunha da localização geográfica dos lotes e das vias de tráfego motorizado e para bicicleta 
existentes, será possível construir a rede viária da RMBS, composta de tramos e nós, através de um Sistema de Informações Geográficas (TransCAD).

O fato de a RMBS possuir um formato longilíneo, limitada pela Serra do Mar e pelo Oceano Atlântico, resulta em zonas de tráfego, principalmente na região montanhosa, com presença de extensas áreas verdes. A eliminação destas áreas não habitadas, nas zonas de tráfego, poderá resultar em distâncias de viagem mais próximas da realidade, já que a maioria das viagens devem ser originadas e destinadas aos núcleos com presença de vias de acesso e construções diversas.

De posse das distâncias pela rede viária e dos tempos reportados entre pares $\mathrm{O} / \mathrm{D}$, será calculada a velocidade média de cada modo alternativo de transporte. Para tanto, serão formados quatro conjuntos de dados desagregados em função do modo de transporte utilizado, a saber: privado, público, bicicleta e à pé. A velocidade média será calculada em cada conjunto de dados e, posteriormente, será utilizada para estimar o tempo de viagem. Ou seja, se a pessoa realiza a viagem através do modo público, será possível estimar os tempos de viagem através dos outros modos de transporte considerados a partir da distância entre os centróides e das velocidades médias obtidas.

Será elaborado também o custo monetário das viagens urbanas através do modo privado e público. O custo do modo privado será obtido a partir da adaptação da formulação proposta por Kawamoto e Setti (1992), que considera que o único custo percebido pelo indivíduo é o custo do combustível, calculado a partir do custo do combustível na época da pesquisa $\mathrm{O} / \mathrm{D}$ e do consumo em $\mathrm{km} / \mathrm{l}$.

Para o modo público, o custo por viagem será obtido a partir do preço da tarifa, diferenciada por se tratar de uma região metropolitana com tarifas intra e intermunicipais, entre os pares $\mathrm{O} / \mathrm{D}$ de origem e destino. A gratuidade será considerada para crianças menores de 6 anos e idosos acima de 65 anos e, quem declarou ser estudante, terá desconto de $50 \%$ no valor da tarifa. Para o caso de trabalhador com carteira assinada, será adotado o menor valor da tarifa entre duas opções: custo da viagem que realiza ou custo da tarifa obtido através do cálculo do valor do passe do trabalhador. 
Salienta-se que apesar de ser limitada pela Serra do Mar, as concentrações populacionais da RMBS estão ao nível do mar e, por este motivo, após investigação das imagens e respectivo levantamento das altitudes através do Google Earth, a maioria das vias não apresenta declividade longitudinal significativa. Desta forma, neste trabalho, a variável relacionada ao relevo existente na RMBS não será considerada como característica das viagens urbanas.

A Tabela 3.1 resume as características das viagens urbanas e características socioeconômicas a serem consideradas no trabalho.

Tabela 3.1 - Resumo das características socioeconômicas e de viagens urbanas consideradas

\begin{tabular}{c|c}
\hline \multicolumn{2}{c}{ Características } \\
\hline Socioeconômicas & Viagens Urbanas \\
\hline Número de automóveis; número de & Alternativas de modo de transporte \\
bicicletas; número de motos; renda & consideradas; tempo de viagem \\
individual e familiar; idade; sexo; situação & reportado; tempo de caminhada; tempo \\
familiar; se estuda ou não, grau de & de espera; distância de viagem; \\
instrução, se trabalha ou não, setor de & velocidade média de cada modo de \\
atividade em que trabalha e vínculo & transporte; tempo de viagem estimado; \\
empregatício & e custo monetário \\
\hline
\end{tabular}

A caracterização da infraestrutura cicloviária terá como objetivo a construção de um indicador a partir de informações, disponibilizadas pelo PCM, sobre ciclovias e/ou ciclofaixas implantadas na RMBS.

Segundo Costa (2003), indicadores são instrumentos que reduzem grande quantidade de informação a um número apropriado de parâmetros para análise e tomada de decisão. Traduzem conceitos abstratos e difíceis de serem mensurados em entidades operacionais e mensuráveis, fornecendo uma informação sintética sobre determinado fenômeno. Sua utilização permite revelar condições e, ao mesmo tempo, tendências, apontando aspectos deficientes ou aqueles que necessitam de intervenção.

Com relação às questões urbanas, os indicadores podem auxiliar na melhor compreensão das questões econômicas, sociais e ambientais, bem como para o conhecimento das características e especificidades dos centros urbanos. Neste nível, podem servir como base 
para a proposição de planos e políticas que visam à melhoria da qualidade de vida da população.

De acordo com a OECD (2002), os indicadores devem ser relevantes e, principalmente, mensuráveis. A mensurabilidade de um indicador é definida por meio da viabilidade de recursos e de tempo; da existência de documentação adequada e da regularidade de atualização dos dados que compõem o indicador. Entende-se como documentação o registro da metodologia de cálculo e também a descrição do método de coleta dos dados que definem e especificam o indicador. Sem uma metodologia adequada de coleta ou de cálculo, e a consequente transferência desse conhecimento para os executores dos programas, fica inviável a obtenção dos dados primários, bem como o correto entendimento e interpretação dos indicadores.

Torna-se imprescindível a regularidade da atualização dos dados utilizados para criação do indicador pois a utilidade, para os tomadores de decisão, é oriunda da possibilidade de comparação entre bases periódicas do objeto em análise.

Segundo Magalhães (2004), para responder às diferentes necessidades de informação e respaldar diversos tipos de análise, existem diversos tipos de indicadores. Estes diferentes tipos podem ser classificados em função do nível de análise a que se prestam, como também pela sua função, ou dimensão de representação. Se classificados por sua dimensão de representação os indicadores podem ser: descritivos, de desempenho ou eficácia, de eficiência e global (EEA, 1999). A caracterização de cada um está sintetizada na Tabela 3.2.

Tabela 3.2 - Tipos de indicadores por função adaptado de EEA (1999)

\begin{tabular}{c|c}
\hline Tipo de Indicador & Descrição \\
\hline Descritivo & $\begin{array}{c}\text { Descrevem, caracterizam um determinado tópico. Refletem } \\
\text { como está a situação, sem a referência de como deveria ser. }\end{array}$ \\
\hline Desempenho ou Eficácia & $\begin{array}{c}\text { Comparam as condições atuais com uma série de valores de } \\
\text { referência, a exemplo de metas ou resultados esperados. }\end{array}$ \\
\hline Eficiência & $\begin{array}{c}\text { Possibilitam a avaliação da eficiência das ações, refletindo } \\
\text { qual a relação, quantitativa e qualitativa, entre meios } \\
\text { empregados e resultados obtidos. }\end{array}$ \\
\hline
\end{tabular}


Nesta Tese de Doutorado, a intenção não é criar um sistema e sim um único indicador que permita avaliar a situação atual e anterior, das ciclovias e/o ciclofaixas implantadas em uma determinada área, através da construção de cenários que caracterizam ambas situações. $\mathrm{O}$ indicador seria do tipo descritivo e buscaria representar a influência ou não da implantação da infraestrutura cicloviária, no caso ciclovias e/ou ciclofaixas, no comportamento individual da escolha do modo de viagem na área em análise.

Com auxílio do Trans $C A D$, que permitirá a construção da rede viária urbana da RMBS e dos centróides das zonas de tráfego, já com a eliminação de áreas não habitadas, será obtido um indicador de dotação de infraestrutura cicloviária baseado na distância percorrida em ciclovias e/ou ciclofaixas em relação ao comprimento total da ligação entre os centróides. Ou seja, o indicador seria dado através da relação:

$$
\text { Indicador }=\frac{\sum R_{i}}{A_{X}}
$$

Em que:

$\mathrm{R}_{\mathrm{i}}$ - distância, de cada trecho, percorrida somente em infraestrutura cicloviária;

$\mathrm{A}_{\mathrm{x}}$ - comprimento total percorrido entre dois centróides.

Vale lembrar que a rota entre os centróides será traçada dentro da própria rede viária urbana da RMBS e, nos casos em que o centróide está localizado em área sem cobertura viária, será adotado o ponto contido na rede mais próximo do mesmo.

O exemplo hipotético, apresentado na Figura 3.2, ilustra a construção do indicador de infraestrutura cicloviária. Na Figura 3.2 há a identificação dos centróides das zonas de tráfego, rede viária, ciclovia e a rota de tempo mínimo. Salienta-se que a distância entre os centróides e os respectivos pontos contidos na rede, mais próximos, não foi considerada. 


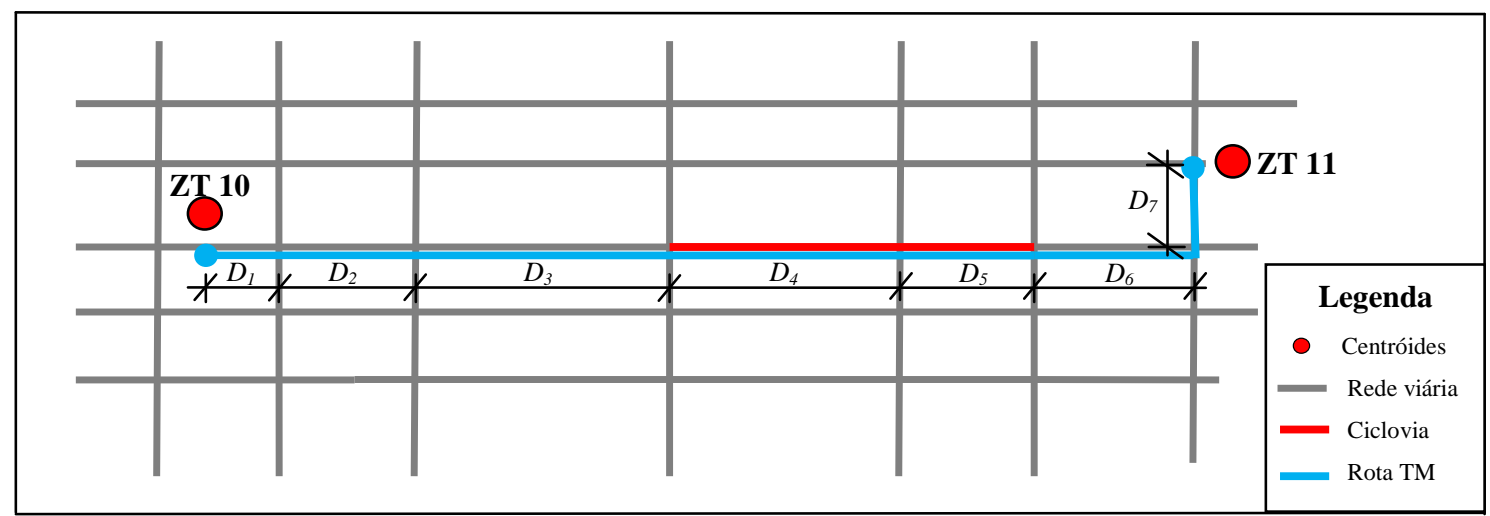

Figura 3.2 - Situação hipotética existente entre centróides de zonas de tráfego com a presença de vias e de ciclovia nas proximidades

As distâncias $D_{1}$ até $D_{7}$ percorridas entre os centróides servem para calcular $\mathrm{O}$ indicador de infraestrutura cicloviária. O indicador é obtido através da relação:

$$
\text { Indicador }=\frac{D_{4}+D_{5}}{D_{1}+D_{2}+D_{3}+D_{4}+D_{5}+D_{6}+D_{7}}
$$

Em que:

$\mathrm{D}_{4}$ e $\mathrm{D}_{5}$ - distâncias percorridas somente em infraestrutura cicloviária;

$\mathrm{D}_{1}, \mathrm{D}_{2}, \mathrm{D}_{3}, \mathrm{D}_{6}$ e $\mathrm{D}_{7}$ - distâncias percorridas pela rede viária.

Serão adotados valores de velocidade diferenciados, em $\mathrm{km} / \mathrm{h}$, para os trechos sem e com infraestrutura cicloviária. Estes valores de velocidade serão baseados nos tempos reportados na pesquisa O/D e nas distâncias percorridas entre centróides pela rede viária normal e pela rede cicloviária existente. A rota que apresenta menor tempo de viagem entre os centróides, e o seu respectivo indicador de infraestrutura cicloviária, será a utilizada no trabalho.

Como a unidade, tanto de origem como de destino de viagem da Pesquisa O/D, é a zona de tráfego, e o indicador de infraestrutura cicloviária está relacionado à extensão percorrida entre dois centróides, optou-se por eliminar as viagens intrazonais para que não houvesse dados do indicador sem informação dentro do banco de dados. Apesar da bicicleta ser reconhecidamente mais utilizada para viagens curtas, acredita-se que os indicadores das viagens feitas pelo modo cicloviário entre zonas de tráfego vizinhas e, mesmo entre zonas 
mais distantes entre si, serão capazes de capturar a influência da infraestrutura cicloviária nas viagens urbanas.

Desta forma, a dotação existente de infraestrutura cicloviária na RMBS, com auxílio da criação deste indicador, será testada com o intuito de verificar se há ou não importância na escolha do modo bicicleta.

\subsection{Estimação de um Modelo de Escolha Discreta}

Inicialmente, serão contatadas todas as Prefeituras Municipais da RMBS com o intuito de obter informações sobre quais ciclovias e/ou ciclofaixas foram implantadas no período compreendido entre o término das contagens volumétricas do PCM (ano 2006) e o início da Pesquisa O/D da RMBS (ano 2007).

Através da informação sobre os locais das ciclovias e/ou ciclofaixas implantadas, vai ser possível saber se há, ou não, pontos de contagem de ciclistas. Dependendo de quais Prefeituras Municipais responderem às solicitações, o banco de dados da O/D da RMBS, a ser utilizado neste trabalho, poderá ser reduzido com o intuito de reduzir esforços na fase de preparação do experimento.

Posteriormente, o fluxograma do método, detalhado na Figura 3.1, prevê a realização da estimação de um modelo de escolha discreta a partir da utilização do banco de dados com informações socioeconômicas, de viagens urbanas e de infraestrutura cicloviária. A técnica de modelagem utilizada irá verificar, através de nível de significância, a hipótese de que é possível identificar e quantificar fatores que influem na escolha do modo cicloviário.

A estimação de um modelo que represente o comportamento individual relacionado à escolha do modo de viagem não é uma tarefa das mais simples pois não é possível observar, e considerar, todos os fatores que possam influenciar esta escolha. No entanto, quanto mais informações acerca da população a ser estudada, menores serão os erros na representação da escolha dos modos de transportes pela população da área em análise.

Os modelos de escolha discreta são baseados na maximização de funções utilidade que, por sua vez, são elaboradas para que possam ser verificados os efeitos de vários 
atributos, dentre eles, socioeconômicos ou de viagens urbanas, no processo decisório do indivíduo ao escolher determinado modo de transporte.

Nesta abordagem, o indivíduo tentará maximizar o seu bem-estar, escolhendo a alternativa que ofereça o maior benefício líquido, ou o menor custo líquido, através da estrutura considerada para representar as funções utilidade de cada alternativa de modo de transporte.

A aplicação será baseada em modelos de escolha discreta do tipo logit multinomial. Será almejada a especificação adequada das funções utilidade que possam estimar, tanto qualitativa como quantitativamente, o efeito das variáveis socioeconômicas e do indicador de infraestrutura cicloviária na escolha específica do modo bicicleta pela população da RMBS.

O modelo Logit Multinomial é utilizado quando a análise da escolha de um produto, ou de um serviço, envolve mais de uma opção como, por exemplo, a escolha de um aparelho de televisão, onde cada indivíduo irá relacionar a importância dos atributos que caracterizam o produto desejado e selecionar aquele que lhe proporciona maior utilidade. No âmbito dos transportes, seria o caso da escolha entre os modos disponíveis naquele momento, por exemplo, trem, carro ou ônibus com suas respectivas características.

As funções utilidade, para cada uma das alternativas de transporte consideradas no trabalho, serão especificadas da seguinte maneira:

$$
U_{n i}=A S C_{i} \pm \sum_{x=1}^{n} \beta_{x} \times \operatorname{Var}_{x}+\varepsilon_{i}
$$

Em que:

$U_{n i}=$ Utilidade associada ao indivíduo $\underline{\mathrm{n}}$ à alternativa $\underline{\mathrm{i}}$;

$A S C_{i}=$ Constante específica da alternativa $\underline{\mathrm{i}}$;

$\beta_{x}=$ Coeficiente da variável $\underline{\mathrm{x}}$ da alternativa $\underline{\mathrm{i}}$;

$\operatorname{Var}_{x}=$ Variável definida que pode influenciar ou não a escolha do modo;

$\epsilon_{i}=$ Representa o erro de percepção da utilidade do modo i.

Segundo Varian (1994), o conceito de Utilidade foi concebido, inicialmente, como uma medida numérica de satisfação de um indivíduo. A função Utilidade é uma forma de 
atribuir um número a cada "pacote de consumo possível", de modo que, aos "pacotes" preferidos, sejam atribuídos valores maiores do que aos "pacotes" menos preferidos.

No modelo logit multinomial podem ser consideradas variáveis do tipo contínua (por exemplo, o custo monetário das viagens), categórica (por exemplo, faixas de idade da população) e do tipo dummy (por exemplo, o sexo representado por “0”, se for mulher, e "1", se for homem). Na fase de preparação do experimento, as variáveis socioeconômicas e do indicador de infraestrutura serão codificadas de forma a atender a necessidade para estimação do modelo de escolha discreta.

Neste trabalho, as variáveis independentes, que irão compor as funções utilidade de cada alternativa de modo de transporte, serão as características socioeconômicas e de viagens urbanas. Especificamente para a alternativa bicicleta será considerado, também como variável independente, o indicador de disponibilidade de infraestrutura cicloviária. Já as variáveis dependentes serão provenientes do resultado do agrupamento dos modos, considerados como possíveis respostas no questionário da O/D da RMBS, em modo privado, público, bicicleta e a pé.

$\mathrm{O}$ modelo, que denota a probalidade $\mathrm{P}_{\mathrm{ni}}$ de o indivíduo $\underline{\mathrm{n}}$ escolher certa alternativa $\underline{\mathrm{i}}$, admitindo-se que a parcela aleatória dos erros são regidos por uma distribuição de Gumbel, independentes e identicamente distribuídos sobre as opções, é expresso por Ben-Akiva e Lerman (1985), como segue:

$$
P_{n i}=\frac{e^{U_{n i}}}{\sum_{j=1}^{j} e^{U_{n j}}}
$$

A estimativa dos parâmetros do modelo logit é feita sob a condição de maximização do logaritmo da função de verossimilhança, expresso por: 


$$
L L\left(\beta^{\prime}\right)=\sum_{n=1}^{N} \sum_{i} y_{n i} \ln P_{n i}
$$

Em que:

$P_{n i}$ é a probabilidade de escolha da alternativa $i$ pelo indivíduo $n$;

$y_{n i}=1$ se o indivíduo $n$ escolhe $i$, e zero se a escolha for diferente;

e $\beta$ ' é o vetor de parâmetros que maximiza o valor da função verossimilhança.

Há vários pacotes estatísticos disponíveis para estimação dos parâmetros dos modelos logit pela maximização da função verossimilhança. Neste trabalho será utilizado o BIOGEME - Bierlaire Optimization toolbox for GEV Estimation (BIERLAIRE, 2009), específico para pesquisa em modelos de escolha discreta.

Para verificação da significância dos parâmetros das variáveis, estimados pelo modelo, será utilizado o teste da estatística $t$ a um nível de significância de 5\%. A estatística $t$ é dada por:

$$
t=\frac{\left(\bar{X}-\mu_{x}\right)}{S / \sqrt{n}}
$$

Em que:

$\bar{X}$ é o parâmetro médio;

$\mu_{\mathrm{x}}$ é zero;

S é o desvio padrão do parâmetro;

e $n$ é o número de observação da amostra.

Para um nível de significância de 5\%, o valor crítico da estatística $t$ é de 1,96 . Se o valor da estatística $t$ for maior que o valor crítico, a hipótese nula de que o parâmetro é igual a zero é rejeitada.

Já para verificação do desempenho do modelo será utilizado o índice de razão da verossimilhança. A estatística mede o desempenho do modelo em duas situações: uma com os parâmetros estimados e a outra com os valores dos parâmetros zerados, ou seja, como se não tivesse o modelo disponível. O cálculo é feito através da relação da função verossimillança 
para os dois casos: uma com os valores estimados para os parâmetros e outra com os valores dos parâmetros iguais a zero. A equação é dada por:

$$
\rho=1-\frac{L L\left(\beta^{\prime \prime}\right)}{L L(0)}
$$

Em que:

$L L(\beta$ ') é o valor da função verossimilhança para os parâmetros estimados;

e $L L(0)$ para os parâmetros iguais a zero.

O valor de $\rho$ varia de zero, menor valor quando os parâmetros estimados não são melhores do que os valores determinados para parâmetros iguais a zero, e até um, quando os parâmetros simulam perfeitamente as escolhas da amostra de indivíduos. Será verificado se o valor obtido de $\rho$ está dentro dos limites utilizados em trabalhos existentes sobre modelos de escolha discreta.

Desta forma, com a aplicação do modelo logit multinomial, espera-se que seja capturada a influência qualitativa, e também quantitativa, da construção de ciclovias e/ou ciclofaixas na RMBS e de fatores socioeconômicos no comportamento dos viajantes urbanos através dos valores dos parâmetros estimados e do cálculo da probabilidade individual de uso da bicicleta.

\subsection{Construção de Cenários}

Após a estimação do modelo logit multinomial que representa a escolha do modo de transporte na RMBS, para o cenário de 2007, e que corrobore com a hipótese de que é possível identificar e quantificar fatores que influem na escolha da bicicleta como modo de transporte, o próximo passo seria a construção do cenário de 2006 que permita a comparação entre o resultado do modelo e o número de viagens de bicicleta que passam pelos pontos de contagem e registrado pelo PCM.

As comparações a serem feitas terão como objetivo testar e verificar as hipóteses desta Tese. Caso o modelo de escolha discreta reproduza adequadamente o volume de ciclistas que passam por pontos de contagem de fluxo de ciclistas, tanto através do cenário de 2007 como de 2006, as hipóteses estarão satisfeitas. 


\subsubsection{Cenário 1}

O primeiro cenário a ser construído terá como objetivo a comparação entre o número de viagens de bicicleta que passam pelos pontos de contagem, obtido diretamente da Pesquisa $\mathrm{O} / \mathrm{D}$, e o resultado da estimação do número de viagens de bicicleta, que passam pelos mesmos pontos, obtidos através do modelo de escolha discreta.

A seleção das viagens da O/D que passam pelos pontos de contagem em análise serão capturadas através do horário de início da viagem, reportado na $\mathrm{O} / \mathrm{D}$, somado ao tempo gasto considerando que a viagem está sendo feita de bicicleta até o referido ponto. Se a viagem estiver dentro do intervalo de 1 hora, haverá a contabilização para comparação. O desenho esquemático da Figura 3.3 ilustra, hipoteticamente, como as viagens da O/D foram contabilizadas.

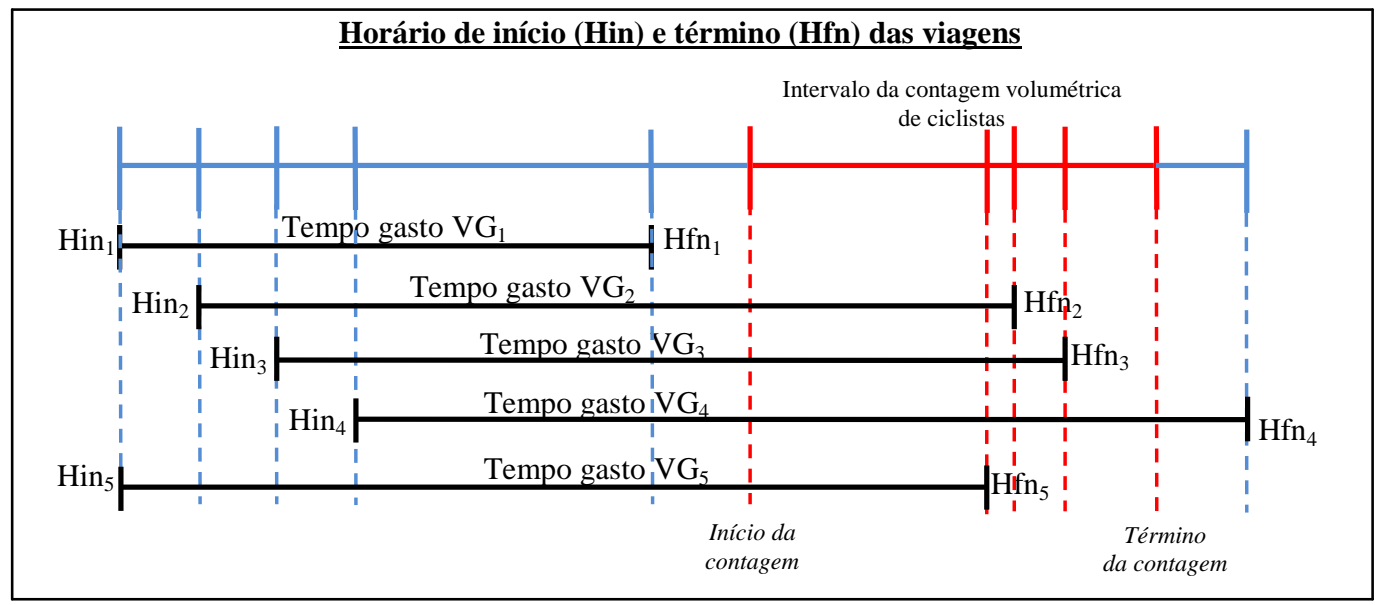

Figura 3.3 - Desenho esquemático para representar a seleção de viagens na O/D

No desenho esquemático, as viagens $\mathrm{VG}_{2}, \mathrm{VG}_{3} \mathrm{e} \mathrm{VG}_{5}$, após a somatória do tempo gasto ao horário de início das viagens, passaram pelo ponto de contagem dentro do intervalo de 1 hora estabelecido como representativo da contagem volumétrica de ciclistas e, portanto, foram selecionadas para fazer parte da análise.

Somente as viagens feitas através da rota de tempo mínimo serão consideradas nesta comparação. Com o auxílio do Trans $C A D$, será calculado o tempo gasto entre a origem (centróides da zona de tráfego) e os pontos de contagem, para cada par O/D, utilizando velocidades de bicicleta em trechos de ciclovias e/ou ciclofaixas e fora delas, e serão 
selecionados os casos em que as viagens de pares $\mathrm{O} / \mathrm{D}$ passaram pelo ponto dentro do intervalo de contagem volumétrica de ciclistas.

Independentemente de a viagem ter sido feita por bicicleta ou por outro modo de viagem, serão considerados todos os pares $\mathrm{O} / \mathrm{D}$ das viagens que passaram pelo ponto de contagem dentro do intervalo de contagem volumétrica de ciclistas. Isto se deve ao fato de que, no modelo logit multinomial, é possível saber as probabilidades individuais de todas as alternativas de transporte mesmo que a pessoa tenha reportado que utilizou apenas 1 modo de transporte.

Desta forma, após seleção das viagens por todas as alternativas de modos de transportes que passam pelos pontos de contagem dentro do intervalo preestabelecido, será calculado o número de viagens de bicicleta através do modelo de escolha discreta nos pontos de contagem. Este cálculo será obtido através da somatória das probabilidades individuais de cada alternativa de modo de transporte multiplicadas pelo fator de expansão de cada viagem. A Tabela 3.3. ilustra, hipoteticamente, a obtenção do resultado através do modelo de escolha discreta e, em destaque, o resultado para o modo bicicleta.

Tabela 3.3 - Obtenção das quantidades de viagens, expandidas, nos pontos de contagem

\begin{tabular}{|c|c|c|c|c|c|c|c|c|c|}
\hline Indivíduo & $\begin{array}{c}\text { Prb. } \\
\text { Privado }\end{array}$ & $\begin{array}{c}\text { Prb. } \\
\text { Público }\end{array}$ & $\begin{array}{c}\text { Prb. } \\
\text { Bicicleta }\end{array}$ & $\begin{array}{l}\text { Prb. } \\
\text { À pé }\end{array}$ & $\begin{array}{c}\text { Fator de } \\
\text { expansão } \\
\text { (F. ex.) }\end{array}$ & $\begin{array}{c}\text { Prb } \\
\text { privado } \\
\text { F. ex. }\end{array}$ & $\begin{array}{c}\text { Prb }_{\text {público }} \\
\text { x } \\
\text { F. ex. }\end{array}$ & $\begin{array}{c}\text { Prb }_{\text {bicicleta }} \\
\text { x } \\
\text { F. ex. }\end{array}$ & $\begin{array}{c}\text { Prb à pé } \\
\text { x } \\
\text { F. ex. }\end{array}$ \\
\hline 1 & 0,4 & 0,3 & 0,2 & 0,1 & 80 & 32 & 24 & 16 & 8 \\
\hline 2 & 0,2 & 0,5 & 0,1 & 0,2 & 70 & 14 & 35 & 7 & 14 \\
\hline . & . & . & $\cdot$ & . & . & . & · & • & . \\
\hline . & . & . & . & . & . & . & . & • & . \\
\hline$\sum$ & $\begin{array}{l}\text { Qt. de. } \\
\text { viagens }\end{array}$ & $\begin{array}{l}\text { Qt. de. } \\
\text { viagens }\end{array}$ & $\begin{array}{l}\text { Qt. de. } \\
\text { viagens }\end{array}$ & $\begin{array}{l}\text { Qt. de. } \\
\text { viagens }\end{array}$ & - & $\begin{array}{l}\text { Qt. de. } \\
\text { viagens } \\
\text { expand. }\end{array}$ & $\begin{array}{l}\text { Qt. de. } \\
\text { viagens } \\
\text { expand. }\end{array}$ & $\begin{array}{l}\text { Qt. de. } \\
\text { viagens } \\
\text { expand. }\end{array}$ & $\begin{array}{l}\text { Qt. de. } \\
\text { viagens } \\
\text { expand. }\end{array}$ \\
\hline
\end{tabular}

Da seleção das viagens por todas as alternativas de modos de transportes que passam pelos pontos serão extraídas somente as viagens feitas de bicicleta e multiplicadas pelos respectivos fatores de expansão dos pares O/D. Desta forma, poderão ser comparados os resultados do modelo e do número de viagens de bicicleta expandidas nos respectivos pontos de contagem de ciclistas. 
Caso o modelo reproduza adequadamente o número de viagens de bicicleta expandidas que passam pelos pontos de contagem, no cenário de 2007, será construído um novo cenário que tentará reproduzir o ano de 2006. Caso contrário, será feita nova caracterização socioeconômica, de viagens urbanas e de infraestrutura cicloviário para que seja refeita a estimação de modelo que possa reproduzir, desta vez, adequadamente o número de viagens de bicicleta de 2007.

\subsubsection{Cenário 2}

O cenário 2 só será trabalhado, segundo o fluxograma da Figura 3.1, se o modelo de escolha discreta reproduzir adequadamente os valores de viagens de bicicleta para o cenário de 2007, ou seja, para o ano em que foi realizada a Pesquisa O/D.

No cenário 2, o objetivo é tentar reproduzir, através do modelo de escolha discreta, o número de viagens de bicicleta contado nos pontos de contagem volumétrica no ano de 2006. Para tanto, serão verificadas quais variáveis socioeconômicas poderiam ter alterado no período compreendido entre o término das contagens volumétricas do PCM e o início das entrevistas domiciliares da O/D da RMBS.

De antemão, uma das variáveis independentes a ser modificada, para que seja possível a comparação, será o indicador de infraestrutura cicloviária. Como ele é proveniente da relação entre distância percorrida em ciclovias e/ou ciclofaixas e distância total entre dois centróides de zonas de tráfego e que, supostamente, não existiam na época da contagem volumétrica de 2006, o valor a ser considerado para o indicador será zero.

Vale ressaltar que o procedimento de comparação, entre o modelo de escolha discreta gerado e contagens volumétrica de ciclistas, será feito no sentido inverso, ou seja, retrocedendo os valores de 2007, de variáveis independentes, para os valores de 2006 destas variáveis.

Uma das técnicas a ser utilizada para identificar se houve ou não alteração em variáveis independentes utilizadas, entre a contagem do PCM e o início das entrevistas domiciliares da $\mathrm{O} / \mathrm{D}$, será o algoritmo CART, embutido na técnica de mineração de dados denominada Árvore de Decisão e Classificação, presente no software S-PLUS 8.0. 
A técnica é considerada uma forma simples de representação de relações existentes em um conjunto de dados. Possui este nome porque a sua estrutura, de fácil entendimento e assimilação, se assemelha a uma árvore. Os dados são divididos em subgrupos, com base nos valores das variáveis independentes consideradas importantes e na variável dependente predominante em cada grupo de indivíduos. O resultado é uma hierarquia de declaração do tipo “Se...então..." que são utilizadas, principalmente, para classificar dados.

A função contida no S-Plus permite analisar até 128 valores de variáveis resposta categóricas, ou dependentes, e 32 para variáveis preditoras, ou independentes, pois se há K níveis de variáveis preditoras, então ocorrerão “ $2(\mathrm{k}-1)-1$ ” divisões, que serão examinadas, impondo alta demanda de processamento computacional.

Para o término das divisões, o S-Plus utiliza dois critérios:

A. Se a homogeneidade dos sub-grupos é menor que um dado índice;

B. O número de observações no nó é menor do que um valor mínimo absoluto.

O S-Plus trata a árvore como modelo de probabilidade, empregando o desvio como critério de divisão. Nas árvores de classificação, a heterogeneidade de cada nó é medida pelo desvio global (D):

$$
D=-2 \sum_{t} \sum_{j \in t} n(j \mid t) \log P(j \mid t)
$$

Em que:

$\mathrm{n}(\mathrm{j} \mid \mathrm{t})$ é o número de casos no nó t com a resposta categórica j;

$\mathrm{P}(\mathrm{j} \mid \mathrm{t})$ denota a proporção dos casos na categoria j do nó t.

Isto significa que na árvore do S-Plus 8.0 o desvio foi definido como recíproco da função verossimilhança elevada ao quadrado. Portanto, o desvio significa uma medida da heterogeneidade dos grupos resultantes.

O S-Plus gera resultados de forma gráfica (Árvore de Decisão e Classificação) e tabular (relatório). Tal relatório apresenta detalhadamente os resultados da árvore: número do nó, total de observações no nó, desvio, padrão predominante e as probabilidades de ocorrência de todas as variáveis respostas. 
Um dos principais motivos que levaram à escolha da árvore de classificação é a sua capacidade de representar a natureza probabilística do objeto analisado que, no caso, seria a variável resposta. Ela é um modelo que reconhece que "indivíduos homogêneos" podem tomar diferentes decisões, e associa a probabilidade às diferentes respostas possíveis.

Espera-se que o Algoritmo CART, através da Árvore de Decisão e Classificação gerada, permita saber se determinada variável independente, considerada no modelo logit multinomial gerado, sofreu alteração significativa no intervalo entre a contagem de ciclistas e a Pesquisa O/D. Para tanto, a variável em análise pode ser considerada como variável resposta, na técnica de mineração de dados, e outras variáveis independentes deverão ser as variáveis preditoras.

Uma das verificações a serem feitas refere-se à posse de bicicletas no domicílio em função do indicador de infraestrutura cicloviária. Acredita-se que, a partir do uso da Árvore de Decisão e Classificação, vai ser possível saber se a posse aumenta ou não em função do maior uso de ciclovias e/ou ciclofaixas nas viagens. A árvore poderá indicar valores médios de posse de bicicletas para grupos homogêneos de indicador de infraestrutura cicloviária e a diferença entre os valores médios de posse, em função do indicador, poderá ser utilizada para simular a situação na época da contagem volumétrica de ciclistas do ano de 2006.

É notório que em um ano se observa variação na produção de setores da economia de um país. A construção civil no Brasil, por exemplo, vêm crescendo consideravelmente nos últimos anos e os motivos, dentre vários, seriam os programas habitacionais do governo federal e medidas que incentivam o crédito imobiliário às diversas classes de renda da população brasileira. Já que uma das variáveis, a ser utilizada, diz respeito ao setor de atividade no qual a pessoa entrevistada está inserida, será investigado também quais setores podem ter sofrido alterações significativa em termos de produção.

Será utilizado a mesma seleção de viagens feita para construção do Cenário 1, e a comparação, desta vez, não será com dados da Pesquisa $\mathrm{O} / \mathrm{D}$, pois há a contagem volumétrica de ciclistas feitas antes da implantação de infraestrutura cicloviária. 
Caso o modelo reproduza adequadamente o número de viagens de bicicleta nos pontos de contagem de bicicleta para o ano de 2006, pode-se afirmar que os parâmetros do modelo podem ser utilizados como instrumento de avaliação e projeto de infraestrutura cicloviária.

A construção de cada um dos cenários será acompanhada de discussões sobre a influência da implantação da infraestrutura cicloviária nas viagens urbanas e demais fatores que influem no uso da bicicleta e haverá a confrontação com os resultados encontrados na literatura existente sobre o assunto. Também, será avaliado se o modelo de escolha discreta estimado servirá como ferramenta útil para os planejadores de transporte ao definir a implantação, ou não, de ciclovias e/ou ciclofaixas com finalidade de incentivar o transporte cicloviário.

Os parâmetros estimados da função utilidade para a alternativa bicicleta irão expressar os fatores que influem no uso da bicicleta e, desta forma, confirmar ou refutar a hipótese de que a implantação de infraestrutura de apoio ao ciclista e fatores como sexo, idade, setor de atividade no qual o indivíduo está inserido, dentre outros, contribuem para o maior uso da bicicleta em áreas urbanas.

Uma das variáveis a ser modificada será o indicador de infraestrutura cicloviária e, caso a comparação confirme que a previsão está adequada, o planejador de transporte, que deseja melhorar a ligação entre zonas de tráfego que, por sua vez, não possuem ciclovias nem ciclofaixas, poderá analisar o impacto que haverá na demanda cicloviária entre as zonas em análise. Ou seja, caso seja melhorada a infraestrutura cicloviária, poderá haver mudança no comportamento dos viajantes urbanos que, provavelmente, passarão a utilizar com mais frequência a bicicleta nos seus deslocamentos em detrimento do uso de outros modos de transporte.

\subsubsection{Síntese do detalhamento do método}

Resumidamente, a sequência do desenvolvimento desta Tese prevê:

- Inicialmente, há pontos de contagem volumétrica de ciclistas antes da implantação de infraestrutura cicloviária (PCM, 2006). A Pesquisa O/D da RMBS servirá para 
obtenção do número de viagens de bicicleta, nos mesmos pontos, após a implantação de ciclovias e/ou ciclofaixas;

- Definição, após contato com as Prefeituras Municipais da RMBS, dos pontos onde não havia infraestrutura cicloviária, e que receberam a infraestrutura no intervalo entre o término das contagens volumétricas do PCM e o início das entrevistas domiciliares da O/D. A amostra da O/D poderá ser reduzida com intuito de reduzir esforços durante a preparação do experimento;

- Será feita a caracterização socioeconômica e de viagens urbanas, obtidas através da Pesquisa $\mathrm{O} / \mathrm{D}$, e da infraestrutura cicloviária, obtida através de informações contidas no PCM, para obtenção de um modelo de escolha discreta;

- O modelo de escolha discreta será estimado após as devidas caracterizações e com a redução ou não do banco de dados, e espera-se que possa servir para identificar e quantificar os fatores que influem no uso de bicicletas e que estes fatores poderão ser usados, ou não, para avaliação e planejamento da implantação de infraestrutura cicloviária;

- Para seleção das viagens na O/D que passam pelos pontos de contagem, serão consideradas todas as viagens provenientes de pares $\mathrm{O} / \mathrm{D}$, independentemente do modo de viagem reportado. O horário de início das viagens somado ao tempo gasto, que será calculado através das distâncias percorridas, da origem até o ponto de contagem, e pelas velocidades de bicicleta, em ciclovia e/ou ciclofaixa e fora delas, servirá para selecionar as viagens que serão utilizadas para comparação. Caso esta somatória esteja dentro do intervalo horário da contagem volumétrica, a viagem será selecionada.

- As contagens volumétricas, que duraram 10 minutos, serão expandidas para 1 hora. Desta forma, tanto para a O/D quanto para as contagens do PCM, a unidade de tempo adotada será a hora; 
- Da seleção das viagens da O/D será extraído o número de viagens de bicicleta expandido para cada ponto de contagem;

- Será construído o cenário 1 que prevê a comparação entre o número de viagens de bicicleta nos pontos de contagem, através do modelo de escolha discreta, com o número de viagens de bicicleta expandido nos mesmos pontos, obtido diretamente da O/D através da seleção das viagens;

- Caso o modelo de escolha discreta reproduza adequadamente o número de viagens de bicicleta nos pontos de contagem, será realizada a construção do cenário 2. Caso contrário, serão feitas novas caracterizações e estimação do modelo de escolha discreta.

- Inicialmente, na construção do cenário 2, será previsto a identificação, entre as variáveis independentes utilizadas para estimação do modelo de escolha discreta, quais são as que podem ter sofrido alterações significativas no intervalo compreendido entre o término da contagem do PCM e o início das entrevistas domiciliares da O/D;

- A variável referente ao indicador de infraestrutura cicloviária é a que obviamente sofreu modificação no referido período;

- Através do uso da Árvore de Decisão e Classificação, será analisado se a posse de bicicletas no domicílio modificará em função do maior, ou menor, valor do indicador de infraestrutura cicloviária;

- Os setores de atividade, nos quais os entrevistados declararam pertencer, também serão avaliados;

- As viagens selecionadas para construção do cenário 1 serão utilizadas para a realização do cenário 2; 
- O modelo de escolha discreta servirá para calcular o número de viagens de bicicleta nos pontos de contagem, através das alterações nas variáveis independentes, e este número será comparado com as contagens volumétricas do PCM;

- Caso o modelo reproduza os valores adequadamente, as hipóteses desta Tese estarão satisfeitas.

- A construção de cada um dos cenários será acompanhada de discussões sobre a influência da implantação da infraestrutura cicloviária nas viagens urbanas e demais fatores que influem no uso da bicicleta e haverá a confrontação com os resultados encontrados na literatura existente sobre o assunto. 


\section{CAPÍTULO 4}

\section{PREPARAÇÃO DO}

EXPERIMENTO

\subsection{Aspectos Gerais}

A Região Metropolitana da Baixada Santista, criada pela Lei Complementar n. ${ }^{\circ} 815$ de 30 de julho de 1996, é composta por 9 municípios que ocupam uma área total de $2.373 \mathrm{~km}^{2}$, o que corresponde a $0,3 \%$ da superfície brasileira e $1,0 \%$ da estadual.

Santos é o município-sede da RMBS, com sua área urbana situada na ilha de São Vicente, conjuntamente com o município de São Vicente. Na parte continental sul estão localizados os municípios de Peruíbe, Itanhaém, Mongaguá e Praia Grande.

Na parte continental central há o município de Cubatão, que se configura como o principal polo industrial da região, destacando-se no setor de siderurgia, refinaria e petroquímica. Ao norte, se localizam os municípios de Guarujá, localizado na Ilha de Santo Amaro, e Bertioga, na parte continental do litoral Norte do Estado de São Paulo. 
A Região Metropolitana da Baixada Santista é de grande importância nacional. Engloba um forte pólo siderúrgico, o maior e mais importante porto da América do Sul, e possui ainda forte vocação turística, responsável por receber enorme parcela dos turistas do Estado de São Paulo que buscam o litoral, tanto pela proximidade com a capital, como pelo fato de ter vias de acesso, as Rodovias Anchieta e dos Imigrantes, que oferecem condições de conforto e segurança bastante satisfatórias nas viagens.

Segundo o relatório técnico da O/D da RMBS (STM, 2007), a região tem uma alta taxa de população urbana $(99,6 \%)$. A Tabela 4.1 traz a relação dos municípios que compõem a RMBS, sua respectiva população, sua participação no total da região e densidade demográfica.

Tabela 4.1 - Dados demográficos da RMBS

\begin{tabular}{|c|c|c|c|c|c|}
\hline \multirow[b]{2}{*}{ Municípios } & \multirow[b]{2}{*}{ Área $\left(\mathbf{k m}^{2}\right)$} & \multicolumn{2}{|c|}{ População Censo 2010} & \multirow{2}{*}{$\begin{array}{c}\text { Densidade } \\
\left(\mathbf{h a b} . / \mathbf{k m}^{2}\right) \\
\text { em } 2010\end{array}$} & \multirow{2}{*}{$\begin{array}{c}\text { População } \\
\text { Censo 2000² }\end{array}$} \\
\hline & & N. Absoluto & $\%$ & & \\
\hline Bertioga & 482 & 45.694 & 2,88 & 94,80 & 30.039 \\
\hline Cubatão & 148 & 116.010 & 7,30 & 783,85 & 108.309 \\
\hline Guarujá & 137 & 260.477 & 16,38 & $1.901,29$ & 264.812 \\
\hline Itanhaém & 581 & 85.952 & 5,41 & 147,94 & 71.995 \\
\hline Mongaguá & 135 & 46.268 & 2,91 & 342,73 & 35.098 \\
\hline Peruíbe & 328 & 59.703 & 3,76 & 182,02 & 51.451 \\
\hline Praia Grande & 145 & 251.526 & 15,82 & $1.734,66$ & 193.582 \\
\hline Santos & 271 & 407.506 & 25,64 & $1.503,71$ & 417.983 \\
\hline São Vicente & 146 & 316.324 & 19,90 & $2.166,60$ & 303.551 \\
\hline $\begin{array}{c}\text { Região } \\
\text { Metropolitana }\end{array}$ & 2.373 & 1.589 .460 & 100,00 & 669,81 & 1.476 .820 \\
\hline
\end{tabular}

Fontes: 1. IBGE, 2010; 2. IBGE, 2000.

O município-sede, Santos, concentra a maior parcela da população e ocupa 11,42\% da área total da região, resultando numa densidade de 1.503,71 habitantes $/ \mathrm{km}^{2}$. Ele é responsável pela maior parte das atividades econômicas, exercendo uma grande polarização sobre a região e concentrando importantes equipamentos de saúde, educação do terceiro grau, comércio e serviços de importância regional, além do maior complexo portuário do país.

Os municípios de São Vicente, Guarujá e Praia Grande ocupam o segundo, terceiro e quarto lugar na participação da população total concentrando, respectivamente, 19,90\%, 
$16,38 \%$ e $15,82 \%$ dos habitantes. A maior densidade populacional da região é observada no município de São Vicente, com 2.166,60 habitantes $/ \mathrm{km}^{2}$.

São Vicente-SP e Praia Grande-SP adquiriram características de cidades-dormitório, apresentando forte conurbação entre si, e que é somente prejudicada pelas restrições de ordem física que impedem de possuir uma mancha urbana contínua.

Os municípios de Bertioga, Itanhaém, Mongaguá e Peruíbe têm forte característica de cidades turísticas e concentram grande quantidade de casas de veraneio. Em período de férias de verão, as populações destes municípios aumentam consideravelmente.

A motorização também é crescente na RMBS, conforme pode ser visto na Tabela 4.2. O indicador, baseado nos totais de frota de automóveis e motocicletas existentes nos municípios que compõem a RMBS, no mês de dezembro dos anos de 2004 a 2011, sofreu um aumento de $57,89 \%$. Isso sugere que a população vem utilizando o transporte motorizado em detrimento de outros modos de transporte econômica e ambientalmente mais viáveis.

Tabela 4.2 - Evolução da taxa de motorização na RMBS

\begin{tabular}{c|c|c|c|c|c|c|c|c}
\hline Ano & 2004 & 2005 & 2006 & 2007 & 2008 & 2009 & 2010 & 2011 \\
\hline $\begin{array}{c}\text { Tx. de Motorização } \\
\text { (veíc/1000 hab.) }\end{array}$ & 297 & 318 & 345 & 378 & 408 & 440 & 478 & 513 \\
\hline
\end{tabular}

Fonte: www.denatran.gov.br

O sistema de transporte público na região é explorado pela iniciativa privada através de concessões efetuadas pelo poder público. Existem 2 sistemas básicos: o de caráter municipal e o de caráter metropolitano, controlado e concedido pelo Estado. Por se tratar de uma região estuarina, existe também o transporte aquático composto por balsas, barcas e catraias, parte controlada pelo Estado e parte operada pela iniciativa privada e também pela cooperativa de catraieiros.

A RMBS conta com uma grande concentração de ciclistas e apresenta características topográficas bastante favoráveis (PCM, 2006). A disponibilidade de áreas propícias à implantação de infraestrutura cicloviária, tais como a orla marítima com praias extensas, o eixo rodoviário das Rodovias Dr. Manoel Hypólito do Rego e Padre Manoel da Nóbrega (SP - 055), e o antigo leito ferroviário da linha Santos - Juquiá, pode permitir que, futuramente, todos os municípios estejam interligados através de ciclovias e/ou ciclofaixas. 


\subsection{Dados da RMBS Disponíveis}

Esta seção descreve os dados envolvidos no estudo, ou seja, os dados referentes à Pesquisa Origem-Destino da RMBS (dados de pesquisa de preferência revelada) e das contagens de tráfego realizadas no desenvolvimento do Plano Cicloviário Metropolitano da Baixada Santista.

\subsubsection{Pesquisa Origem-Destino da RMBS (STM, 2007)}

A Pesquisa Origem-Destino (O/D) na RMBS foi realizada entre os meses de outubro e dezembro de 2007 e fevereiro e abril de 2008 e contemplou mais de 8000 domicílios entrevistados nos municípios que compõem a região metropolitana.

Foram definidas 188 zonas de tráfego pertencentes à RMBS e 26 zonas externas. No estudo, considera-se apenas as zonas internas localizadas na RMBS. A Tabela 4.3 mostra o número de zonas de tráfego por município. As Figuras 4.1 e 4.2 ilustram a distribuição espacial das zonas na RMBS.

Tabela 4.3 - Zoneamento na RMBS

\begin{tabular}{c|c}
\hline Municípios & Zonas de Tráfego \\
\hline Bertioga & $13($ de 01 até 13$)$ \\
\hline Cubatão & $15($ de 83 até 97$)$ \\
\hline Guarujá & $23($ de 14 até 36$)$ \\
\hline Itanhaém & $16($ de 158 até 173$)$ \\
\hline Mongaguá & $9($ de 149 até 157$)$ \\
\hline Peruíbe & $15($ de 174 até 188$)$ \\
\hline Praia Grande & $13($ de 136 até 148$)$ \\
\hline Santos & $46($ de 37 até 82$)$ \\
\hline São Vicente & $38($ de 98 até 135$)$ \\
\hline Total & $\mathbf{1 8 8}$ \\
\hline Zonas Externas & $\mathbf{2 6}$ \\
\hline
\end{tabular}

Fonte: Relatório Técnico - Pesquisa Origem-Destino 2007 da RMBS (STM, 2007)

A amostra é composta por 12.507 homens $(47,80 \%$ da amostra) e 13.658 mulheres (52,20\%). Já os números de estudantes e trabalhadores representam 24,93\% e 37,43\%, respectivamente. 


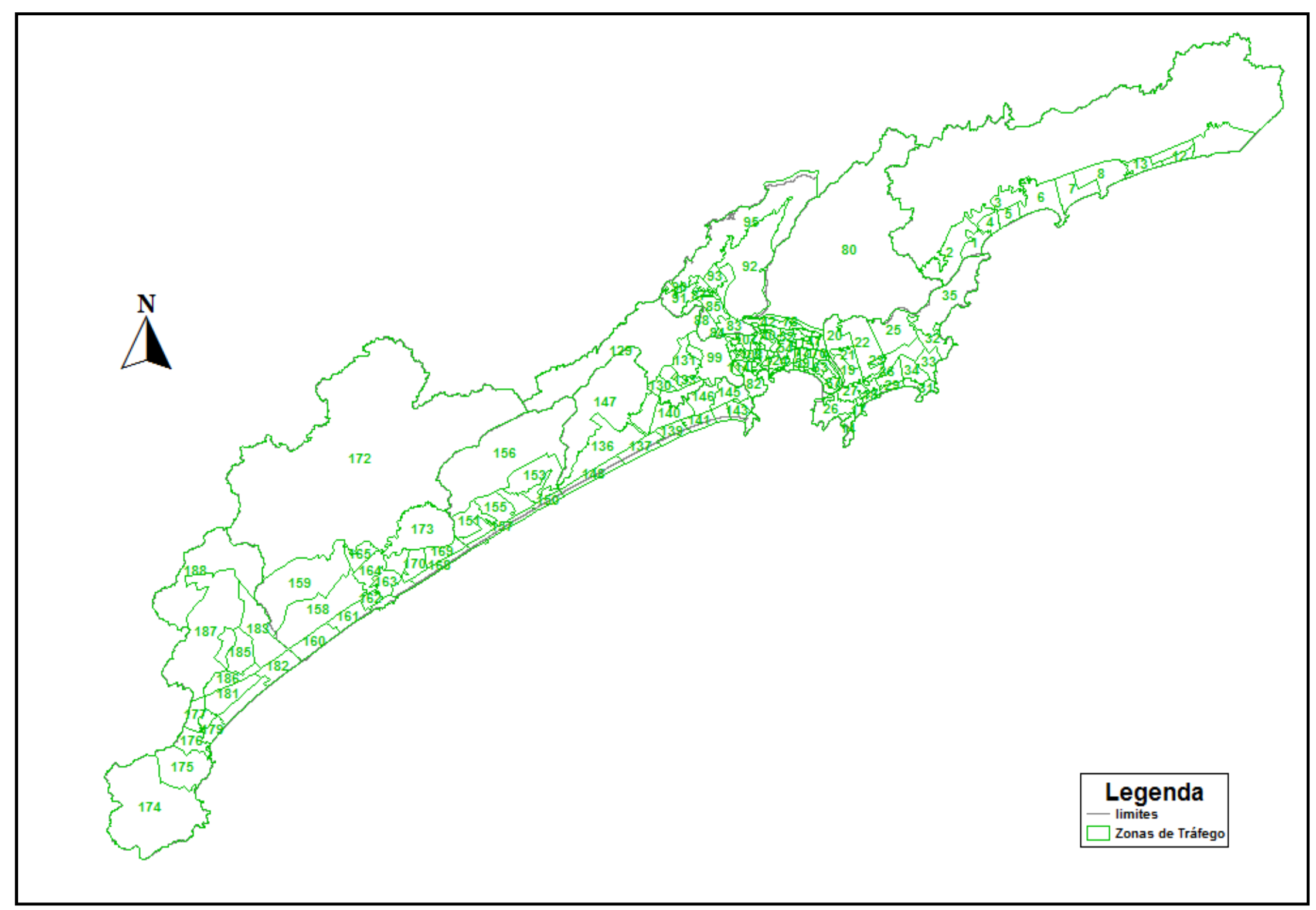

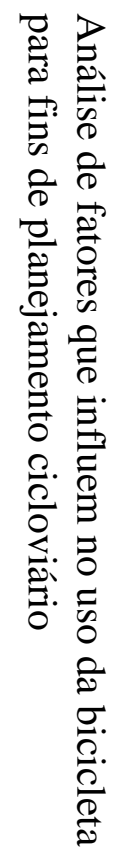

Figura 4.1 - Distribuição espacial das zonas de Tráfego na RMBS 


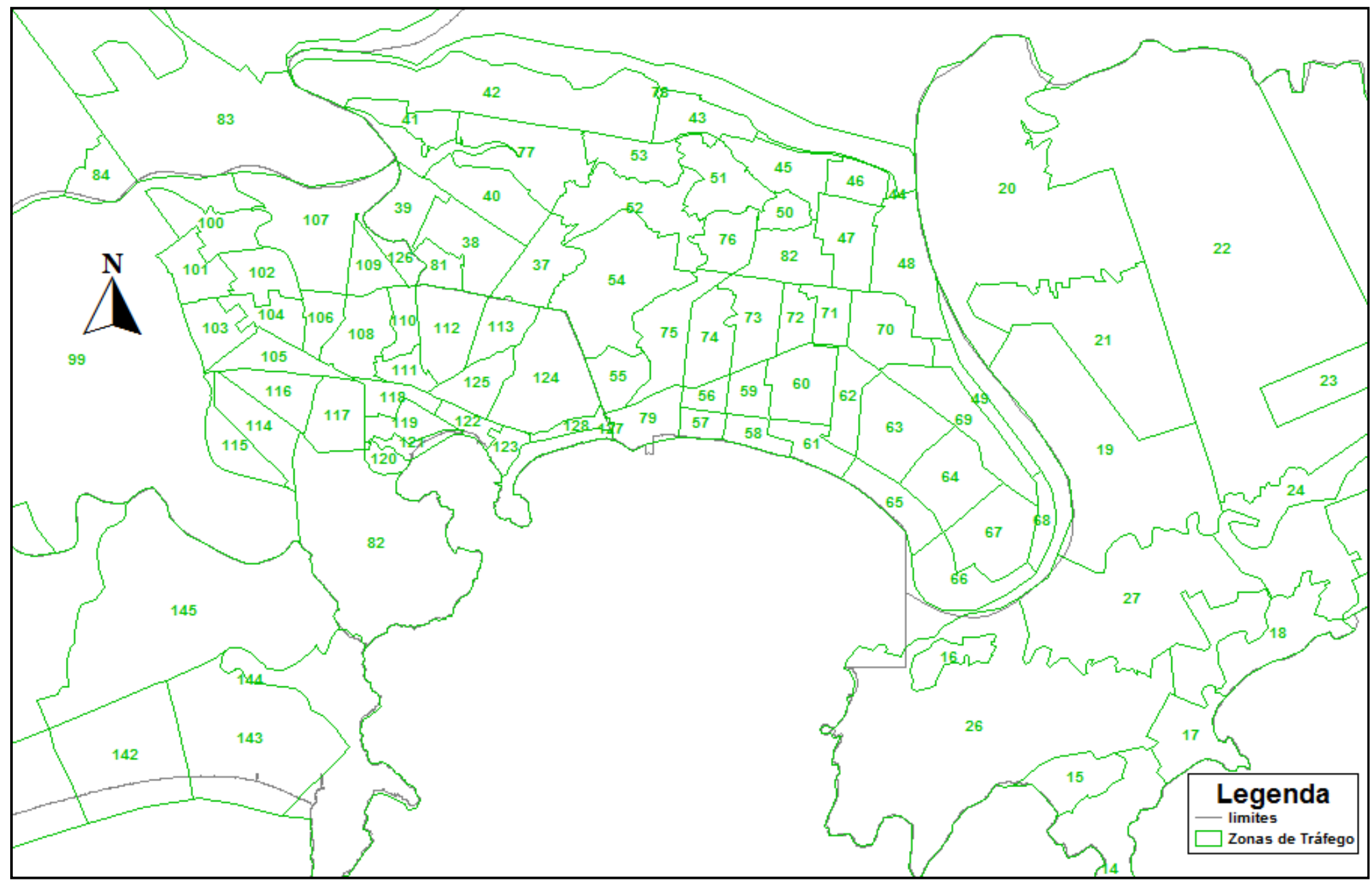

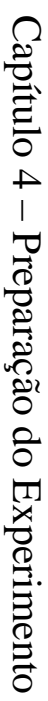

Figura 4.2 - Detalhamento da distribuição espacial das zonas de Tráfego na parte central da RMBS 
Disponibilizado pela Secretaria de Estado dos Transportes Metropolitanos - STM/SP, para o uso neste trabalho, o banco de dados contempla informações sobre os domicílios, famílias, pessoas e viagens realizadas. Contém 8.116 domicílios pesquisados e 26.165 pessoas entrevistadas, que realizaram 30.373 viagens. Vale ressaltar que foram consideradas como viagens os deslocamentos com distância superior a 500 metros (5 quadras) ou quando o motivo da viagem, independentemente da distância percorrida, for trabalho ou escola.

Do banco de dados original foi obtida a versão reduzida contendo somente os dados das viagens originadas e destinadas aos municípios de Guarujá-SP, Santos-SP e São VicenteSP pois estas foram as únicas prefeituras a responder às solicitações do Programa de PósGraduação em Planejamento e Operação de Transportes da EESC/USP, enviando dados de ciclovias e/ou ciclofaixas implantadas no período compreendido entre o término das contagens volumétricas do Plano Cicloviário Metropolitano da Baixada Santista (PCM, 2006) e o início da Pesquisa O/D da RMBS (STM, 2007).

A amostra reduzida contabilizou 4.890 indivíduos, composta por 2.852 homens $(58,32 \%)$ e 2.038 mulheres $(41,68 \%)$. A Figura 4.3 mostra a distribuição etária de homens e mulheres da amostra. Há predominância da população em faixas de idade centrais e não há diferença significativa na idade média, sendo 36 anos para homens contra 35 anos para mulheres, respectivamente.

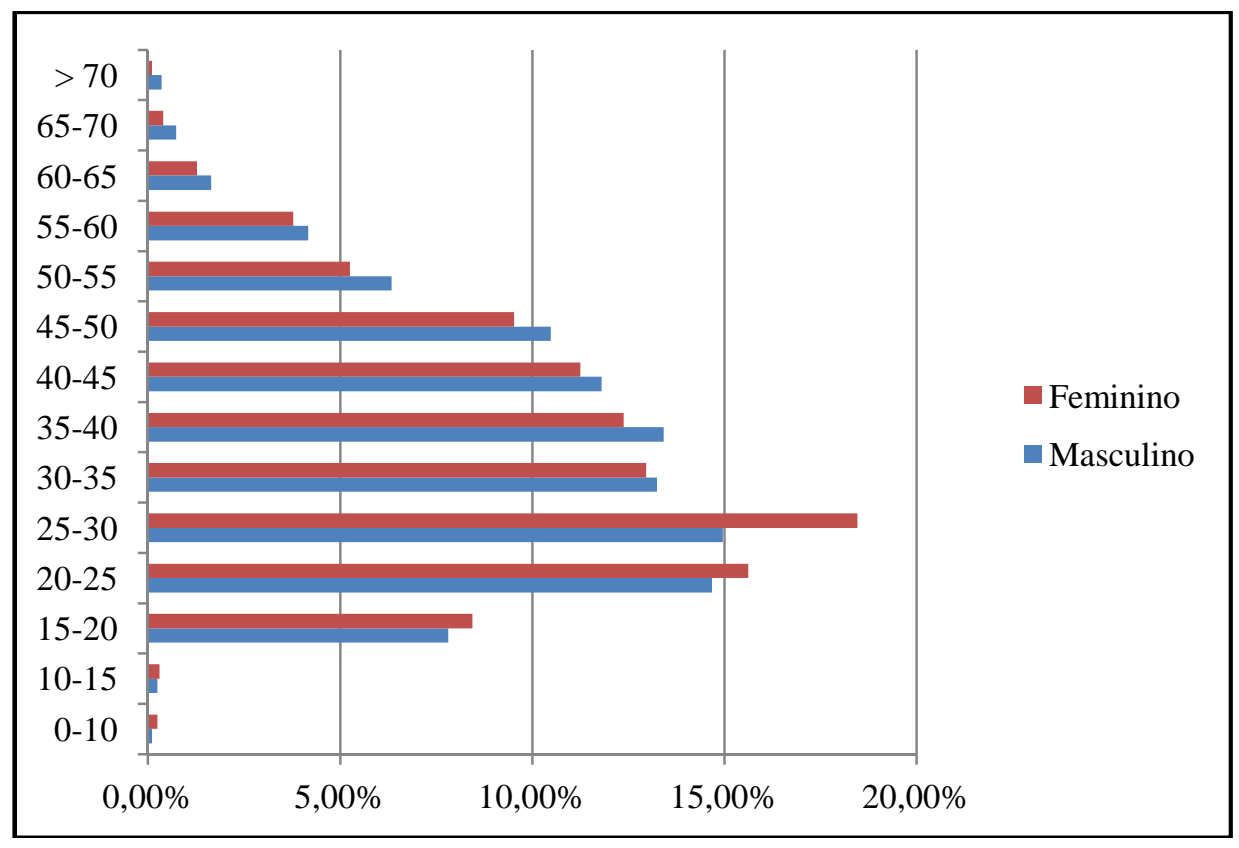

Figura 4.3 - Distribuição da amostra reduzida por faixa etária 
A Figura 4.4 mostra a distribuição da remuneração domiciliar da amostra reduzida. Vale ressaltar que, tanto para homens quanto para mulheres, a concentração de renda está principalmente na primeira faixa de remuneração, ou seja, de 0 até $\mathrm{R} \$ 800,00$, o que sugere a baixa remuneração de trabalhadores da região.

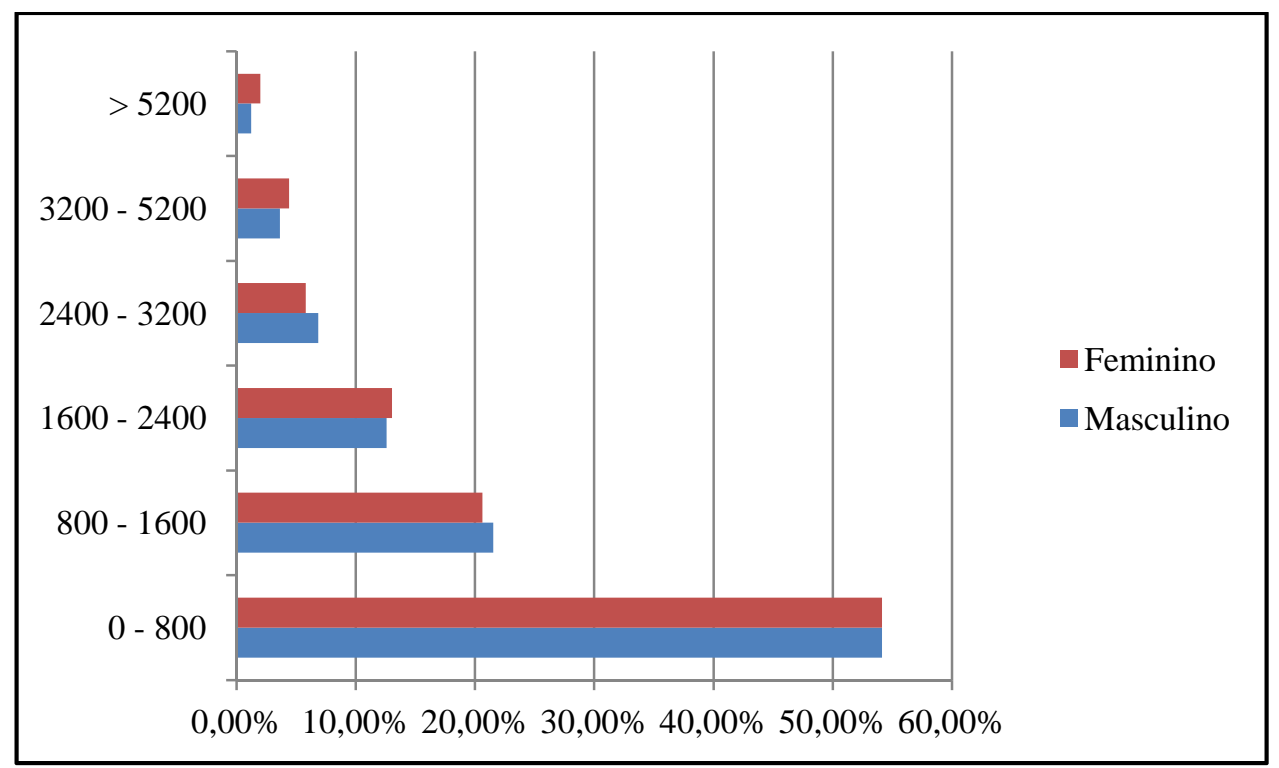

Figura 4.4 - Distribuição da amostra reduzida por faixa de renda domiciliar

Já a distribuição da remuneração individual da amostra da O/D mostra um comportamento distinto, conforme a Figura 4.5, da distribuição domiciliar presente na Figura 4.4. Por exemplo, as faixas de renda a partir de $\mathrm{R} \$ 2.400,00$ até acima de $\mathrm{R} \$ 5.200,00$ apresentam percentuais quase inexistentes, diferentemente do encontrado na distribuição por faixa de renda domiciliar. Um dos motivos seria, provavelmente, o fato de que, além do chefe da família, há mais de um indivíduo responsável pela subsistência da família.

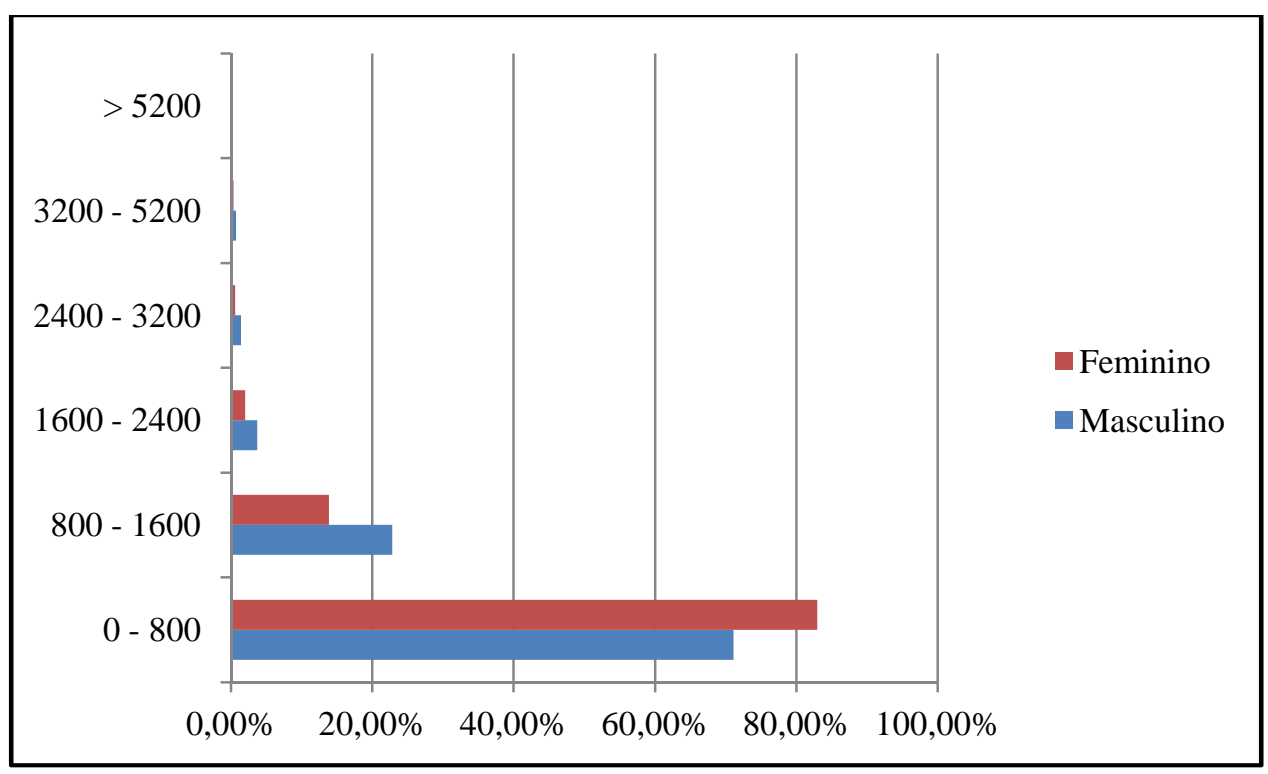

Figura 4.5 - Distribuição da amostra reduzida por faixa de renda individual 
Os indivíduos da amostra reduzida foram responsáveis por 11.067 viagens e, agrupando os motivos de viagem em 4 classes (viagens para trabalho, escola, outras atividades e retorno para casa), a Tabela 4.4 mostra a distribuição dos motivos de viagem das viagens originadas e destinadas aos municípios de Guarujá-SP, Santos-SP e São Vicente-SP. Com exceção do retorno para casa, a demanda pelo motivo trabalho apresenta o maior percentual em relação aos percentuais de viagem à escola e para realizar outras atividades, como saúde, compras, lazer, dentre outros.

Tabela 4.4 - Percentuais da distribuição dos motivos de viagem da amostra reduzida

\begin{tabular}{c|c|c}
\hline Motivo da viagem & Frequência & \% \\
\hline Trabalho & 4838 & 43,72 \\
\hline Escola & 592 & 5,35 \\
\hline Outras atividades & 276 & 2,49 \\
\hline Retornando para casa & 5361 & 48,44 \\
\hline
\end{tabular}

Com relação às informações sobre os modos de transporte, a O/D da RMBS continha treze opções de resposta no questionário utilizado. Conforme mostra a Tabela 4.5, optou-se por agrupar estes modos de transportes em apenas cinco itens: privado, público, bicicleta, a pé e outros. O modo público apresentou o maior percentual $(43,26 \%)$, seguido do modo privado $(25,93 \%)$. Comparando os modos motorizados versus não-motorizados, os percentuais foram de $69,20 \%$ e $30,01 \%$, respectivamente.

Tabela 4.5 - Agrupamento e distribuição dos modos de viagem da amostra reduzida

\begin{tabular}{c|c|c|c}
\hline Modo de Viagem Contido na O/D & $\begin{array}{c}\text { Modo de } \\
\text { Viagem } \\
\text { Agrupado }\end{array}$ & Frequência & $\%$ \\
\hline $\begin{array}{c}\text { 1 - Dirigindo automóvel; 2- Passageiro } \\
\text { de auto; 3 - Táxi; 4 - Moto }\end{array}$ & Privado & 2870 & 25,93 \\
\hline $\begin{array}{c}\text { 5- Ônibus municipal; 6 - Ônibus } \\
\text { intermunicipal; } 7 \text { - Lotação/Van/Perua; } \\
8-\text { Microônibus; } 9 \text { - Ônibus Fretado; } \\
\text { 10 - Transporte escolar }\end{array}$ & Público & 4788 & 43,26 \\
\hline $11-$ Bicicleta & Bicicleta & 1489 & 13,45 \\
\hline $12-$ A pé & A pé & 1832 & 16,55 \\
\hline $13-$ Outros & Outros & 88 & 0,80 \\
\hline
\end{tabular}

Predominantemente é verificado o uso do modo público em faixas de renda domiciliar mais baixas ( 0 - $\mathrm{R} \$ 800,00$ até $\mathrm{R} \$ 2.400,00-\mathrm{R} \$ 3.200,00)$, conforme é mostrado na Tabela 4.6. Os modos bicicleta e a pé, ou seja, não-motorizados, também apresentam percentuais consideráveis nas faixas de renda compreendidas entre 0 - R\$800,00; R\$ 800,00 - 
$\mathrm{R} \$ 1.600,00$ e $\mathrm{R} \$ 1.600,00$ - $\mathrm{R} \$ 2.400,00$; e estes percentuais, se somados, superam o percentual do modo privado nas respectivas faixas de renda. Com o aumento da renda domiciliar, cresce a participação do modo privado e, nas faixas de renda de $R$ \$3.200,00 - R\$ 5.200,00 e acima de $\mathrm{R} \$ 5.200,00$, constitui-se como principal modo de viagem utilizado na amostra reduzida.

Tabela 4.6 - Divisão modal segundo faixas de renda domiciliar da amostra reduzida

\begin{tabular}{c|c|c|c|c|c}
\hline Faixas de renda domiciliar & Privado $(\boldsymbol{\%})$ & Público $(\boldsymbol{\%})$ & Bicicleta $(\%)$ & A pé $(\boldsymbol{\%})$ & Outros $(\boldsymbol{\%})$ \\
\hline 0 - R\$ 800,00 & 24,90 & 43,06 & 15,08 & 16,43 & 0,53 \\
\hline $\mathrm{R} \$ 800,00-\mathrm{R} \$ 1.600,00$ & 20,43 & 44,86 & 16,51 & 17,22 & 0,98 \\
\hline $\mathrm{R} \$ 1.600,00-\mathrm{R} \$ 2.400,00$ & 24,93 & 43,73 & 9,26 & 21,45 & 0,63 \\
\hline $\mathrm{R} \$ 2.400,00-\mathrm{R} \$ 3.200,00$ & 34,11 & 42,16 & 7,37 & 13,64 & 2,73 \\
\hline $\mathrm{R} \$ 3.200,00-\mathrm{R} \$ 5.200,00$ & 43,89 & 41,48 & 5,24 & 8,52 & 0,87 \\
\hline$>\mathrm{R} \$ 5.200,00$ & 56,25 & 35,94 & 1,04 & 6,25 & 0,52 \\
\hline
\end{tabular}

De posse da Tabela 4.7, se verificada a soma dos percentuais dos modos nãomotorizados versus o modo privado em relação aos motivos das viagens realizadas, é possível notar maiores percentuais para os modos não-motorizados em todos os motivos, exceto para outras atividades, o que demonstra que a população da RMBS, no seu dia-a-dia, utiliza de forma significativa a bicicleta e a caminhada para realizar suas atividades. Vale ressaltar que o modo público, exceto para a atividade de estudo, foi o modo de transporte mais utilizado pela população da amostra reduzida.

Tabela 4.7 - Divisão modal da amostra reduzida segundo motivos de viagem

\begin{tabular}{c|c|c|c|c|c|c|c|c}
\hline \multirow{2}{*}{ Modo } & \multicolumn{2}{|c|}{ Trabalho } & \multicolumn{2}{c|}{ Escola } & \multicolumn{2}{c|}{ Outras atividades } & \multicolumn{2}{c}{ Retornando para casa } \\
\cline { 2 - 10 } & Frequência & $\mathbf{\%}$ & Frequência & $\mathbf{\%}$ & Frequência & \% & Frequência & \% \\
\hline Privado & 1250 & 25,84 & 134 & 22,64 & 98 & 35,51 & 1388 & 25,89 \\
\hline Público & 2188 & 45,23 & 183 & 30,91 & 108 & 39,13 & 2309 & 43,07 \\
\hline Bicicleta & 663 & 13,70 & 77 & 13,01 & 24 & 8,70 & 725 & 13,52 \\
\hline A pé & 703 & 14,53 & 193 & 32,60 & 43 & 15,58 & 893 & 16,66 \\
\hline Outros & 34 & 0,70 & 5 & 0,84 & 3 & 1,09 & 46 & 0,86 \\
\hline
\end{tabular}

Dos 4.890 indivíduos da amostra reduzida da O/D, 56,61\% não são chefes de família (Tabela 4.8), 64,46\% dos domicílios não possuem automóveis (Tabela 4.9) e 75,46\% não possuem motos (Tabela 4.10). Ressalta-se que, com o aumento do número de automóveis e de motos, é verificado que a taxa média de viagens aumenta, indicando que a disponibilidade de modos de transporte, do tipo privado motorizado, contribui para aumentar a mobilidade 
dos membros do domicílio. Por outro lado, a posse, tanto de automóveis quanto de motos, aumenta em domicílios com um maior número de moradores.

Tabela 4.8 - Situação familiar dos indivíduos da amostra reduzida

\begin{tabular}{c|c|c|c}
\hline Situação Familiar & Frequência & \% & $\begin{array}{c}\text { Taxa média de } \\
\text { viagens }\end{array}$ \\
\hline Chefe & 2122 & 43,39 & 2,19 \\
\hline Cônjuge & 876 & 17,91 & 2,23 \\
\hline Filho (a) & 1479 & 30,25 & 2,31 \\
\hline Outro parente & 360 & 7,36 & 2,20 \\
\hline Agregado & 49 & 1,00 & 2,10 \\
\hline Empregado residente & 2 & 0,04 & 3,00 \\
\hline Outros & 2 & 0,04 & 3,00 \\
\hline
\end{tabular}

Tabela 4.9 - Posse de automóveis nos domicílios da amostra reduzida

\begin{tabular}{c|c|c|c|c}
\hline $\begin{array}{c}\text { Posse de } \\
\text { automóveis }\end{array}$ & Frequência & $\%$ & $\begin{array}{c}\text { Taxa média } \\
\text { de viagens }\end{array}$ & $\begin{array}{c}\text { Número médio de } \\
\text { moradores no domicílio }\end{array}$ \\
\hline 0 & 3152 & 64,46 & 2,19 & 4,03 \\
\hline 1 & 1465 & 29,96 & 2,29 & 4,03 \\
\hline 2 & 234 & 4,79 & 2,44 & 4,24 \\
\hline$>=3$ & 39 & 0,80 & 2,48 & 4,43 \\
\hline
\end{tabular}

Tabela 4.10 - Posse de motos nos domicílios da amostra reduzida

\begin{tabular}{c|c|c|c|c}
\hline $\begin{array}{c}\text { Posse de } \\
\text { motos }\end{array}$ & Frequência & $\%$ & $\begin{array}{c}\text { Taxa média } \\
\text { de viagens }\end{array}$ & $\begin{array}{c}\text { Número médio de } \\
\text { moradores no domicílio }\end{array}$ \\
\hline 0 & 3690 & 75,46 & 2,23 & 4,01 \\
\hline 1 & 1066 & 21,80 & 2,23 & 4,01 \\
\hline 2 & 113 & 2,31 & 2,28 & 5,06 \\
\hline$>=3$ & 21 & 0,43 & 2,33 & 6,05 \\
\hline
\end{tabular}

Já a bicicleta, por ser um modo de transporte de baixo custo de aquisição, é mais frequente nos domicílios da amostra reduzida da O/D (Tabela 4.11). Novamente, com o aumento do número de moradores do domicílio, torna-se necessário que haja mais modos de transporte disponíveis e, desta maneira, a posse de bicicletas é maior quanto maior for o número de moradores no domicílio. 
Tabela 4.11 - Posse de bicicletas nos domicílios da amostra reduzida

\begin{tabular}{c|c|c|c|c}
\hline $\begin{array}{c}\text { Posse de } \\
\text { bicicletas }\end{array}$ & Frequência & \% & $\begin{array}{c}\text { Taxa média } \\
\text { de viagens }\end{array}$ & $\begin{array}{c}\text { Número médio de } \\
\text { moradores no domicílio }\end{array}$ \\
\hline 0 & 1356 & 27,73 & 2,25 & 3,53 \\
\hline 1 & 1941 & 39,69 & 2,20 & 3,87 \\
\hline 2 & 1062 & 21,72 & 2,23 & 4,41 \\
\hline$>=3$ & 531 & 10,86 & 2,33 & 5,23 \\
\hline
\end{tabular}

Das 1489 viagens que utilizaram bicicleta como modo de transporte, a posse de bicicletas também deve influenciar a escolha pelo referido modo. Conforme indica a Figura 4.6, quando comparados a posse de quem usou a bicicleta e de quem não usou, verifica-se um aumento significativo de bicicletas no domicílio de quem viajou de bicicleta. Nota-se também que, aproximadamente, $93 \%$ dos domicílios possuíam 1 ou mais bicicletas contra $68 \%$ nos domicílios que não viajaram de bicicleta.

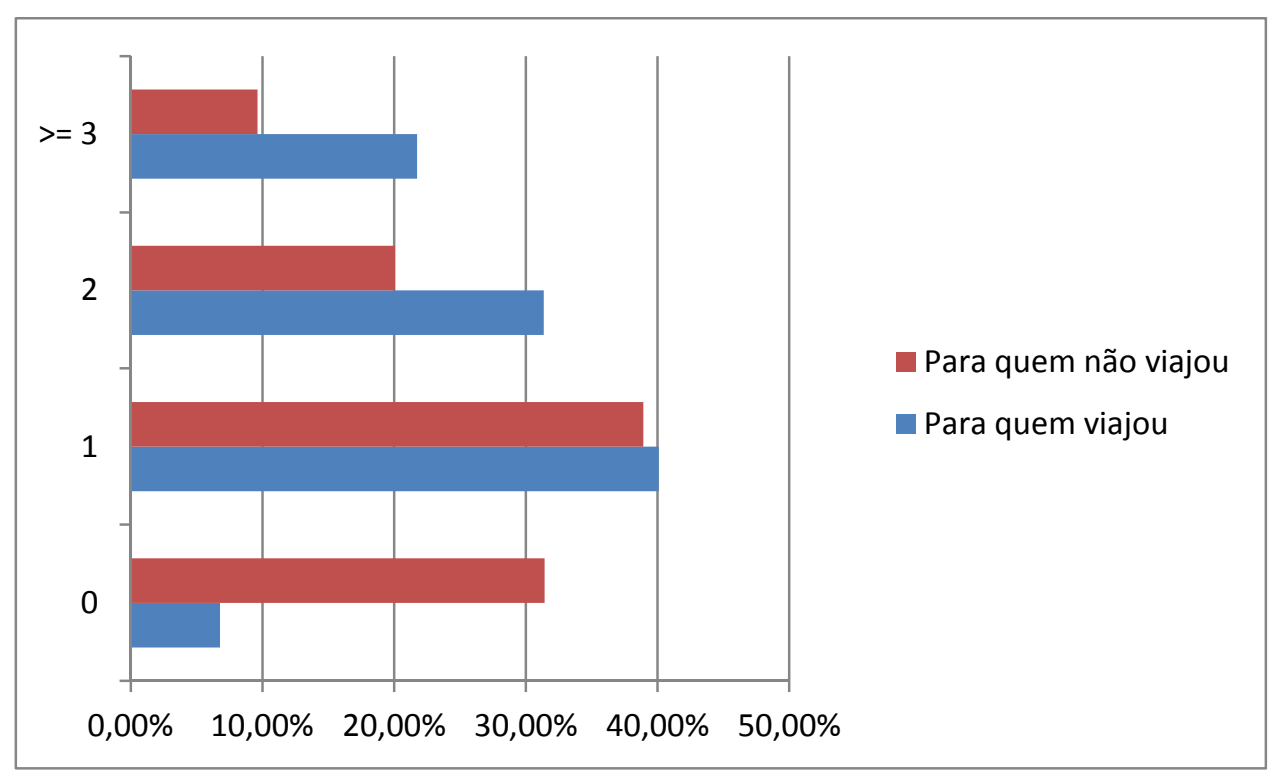

Figura 4.6 - Posse de bicicletas de viagens feitas de bicicleta ou não na amostra reduzida

É possível que a atividade de trabalho, em que o indivíduo está inserido, também influencie a escolha do modo de viagem. A bicicleta, por exemplo, devido ao fato de ser de propulsão humana, pode necessitar que o usuário tenha vestiários disponíveis no destino final pois, muitas vezes, ele chega ao destino suado, e a vestimenta utilizada ao pedalar pode não condizer com a atividade exercida de trabalho ou vice-versa. A Tabela 4.12 mostra a distribuição da amostra reduzida pelos diferentes setores de atividade exercidos em relação ao sexo e respectivas frequências, percentuais relativos e taxas médias de viagem. Salienta-se que a atividade "Serviços" é resultado do agrupamento de setores de serviço coletados através 
do questionário utilizado na O/D. Foram eles: transporte de carga; transporte de passageiros; creditícios - financeiros; pessoais; alimentação; saúde; educação; especializados; e de administração pública.

Tabela 4.12 - Distribuição dos setores de atividade em relação ao sexo e respectivas frequências, percentuais relativos e taxas médias de viagem

\begin{tabular}{c|c|c|c|c|c|c}
\hline \multirow{2}{*}{$\begin{array}{c}\text { Setor de } \\
\text { Atividade }\end{array}$} & Frequência & $\%$ & $\begin{array}{c}\text { Taxas médias } \\
\text { de viagem }\end{array}$ & Frequência & $\%$ & $\begin{array}{c}\text { Taxas médias } \\
\text { de viagem }\end{array}$ \\
\cline { 2 - 7 } & 15 & 0,53 & 2,33 & 0 & 0,00 & 0,00 \\
\hline Agrícola & 488 & 17,11 & 2,24 & 435 & 21,34 & 2,26 \\
\hline Comércio & 190 & 6,66 & 2,26 & 11 & 0,54 & 2,18 \\
\hline Construção Civil & 156 & 5,47 & 2,14 & 7 & 0,34 & 2,43 \\
\hline Indústria & 1235 & 43,30 & 2,24 & 870 & 42,69 & 2,38 \\
\hline Serviços & 768 & 26,93 & 2,11 & 715 & 35,08 & 2,19 \\
\hline Outros & \multicolumn{1}{|c|}{ \%omem }
\end{tabular}

Tanto pessoas do sexo masculino quanto feminino estão engajadas, preponderantemente, em atividades relacionadas ao comércio e serviços. No entanto, vale destacar, em setores da construção civil e da indústria, a participação maior de homens em relação a mulheres.

O número de bicicletas no domicílio também é significativamente diferente em relação aos setores de atividade (Tabela 4.13). Em domicílios onde o entrevistado trabalha na construção civil, por exemplo, apenas $8,96 \%$ não possuem bicicleta. Nos demais setores o percentual fica aproximadamente igual a $30 \%$.

Tabela 4.13 - Distribuição dos setores de atividade em relação à posse de bicicletas no domicílio e respectivas frequências e percentuais relativos

\begin{tabular}{c|c|c|c|c|c|c|c|c}
\hline \multirow{2}{*}{$\begin{array}{c}\text { Setor de } \\
\text { Atividade }\end{array}$} & \multicolumn{9}{|c|}{ Posse de bicicletas no domicílio } & \multicolumn{2}{c}{$\mathbf{2}$} & \multicolumn{2}{c}{$\mathbf{2}$} \\
\cline { 2 - 10 } & Frequência & \% & Frequência & \% & Frequência & \% & Frequência & $\%$ \\
\hline & 4 & 26,67 & 3 & 20,00 & 5 & 33,33 & 3 & 20,00 \\
\hline Agrícola & 264 & 28,60 & 357 & 38,68 & 212 & 22,97 & 90 & 9,75 \\
\hline Comércio & 18 & 8,96 & 98 & 48,76 & 54 & 26,87 & 31 & 15,42 \\
\hline Construção Civil & 54 & 33,13 & 53 & 32,52 & 33 & 20,25 & 23 & 14,11 \\
\hline Indústria & 624 & 29,64 & 827 & 39,29 & 430 & 20,43 & 224 & 10,64 \\
\hline Serviços & 392 & 26,43 & 603 & 40,66 & 328 & 22,12 & 160 & 10,79 \\
\hline Outros & & & & & & & \\
\hline
\end{tabular}




\subsubsection{Plano Cicloviário Metropolitano da RMBS (PCM, 2006)}

A Secretaria de Transportes Metropolitanos, por intermédio da Agência Metropolitana da Baixada Santista - AGEM, elaborou o Plano Cicloviário Metropolitano - PCM da RMBS, em 2006, com intuito de planejar e otimizar os recursos e ações na RMBS e subsidiar as decisões de investimento do Poder Público.

O PCM foi formulado com base na Malha Cicloviária existente, no diagnóstico traçado para a situação atual; na análise e no reconhecimento em campo dos planos das Prefeituras Municipais para implantação de novas ciclovias; e nos estudos desenvolvidos por outros órgãos.

A expansão da Malha Cicloviária é prevista para que ocorra em 3 etapas, sendo a primeira dentro do período entre 2006 e 2011 (ações de curto prazo), a segunda entre 2011 e 2016 (ações de médio prazo) e a última entre 2016 e 2026 (ações de longo prazo).

A AGEM disponibilizou o mapa, em formato digital, da RMBS com todas as ciclovias e/ou ciclofaixas construídas até o ano de 2007 para ser utilizado no trabalho ora desenvolvido. Vale ressaltar que esse mapa é de grande valia para a obtenção dos indicadores de infraestrutura cicloviária a ser desenvolvida em um Sistema de Informações Geográficas (TransCAD). A Tabela 4.14 mostra a extensão da Malha Cicloviária (em km) em 2006 e nos horizontes previstos a curto, médio e longo prazo nos municípios que compõem a RMBS.

Tabela 4.14 - Extensão da Malha Cicloviária na RMBS

\begin{tabular}{c|c|c|c|c}
\hline \multirow{2}{*}{ Município } & \multicolumn{4}{|c}{ Extensão da Malha Cicloviária (km) } \\
\cline { 2 - 5 } & Existente (2006) & $\mathbf{2 0 1 1}$ & $\mathbf{2 0 1 6}$ & $\mathbf{2 0 2 6}$ \\
\hline Bertioga & 7,43 & 34,68 & 47,38 & 52,98 \\
\hline Cubatão & 10,92 & 38,76 & 43,26 & 33,26 \\
\hline Guarujá & 16,47 & 29,36 & 35,60 & 83,58 \\
\hline Itanhaém & 6,45 & 48,51 & 83,58 & 20,69 \\
\hline Mongaguá & 7,48 & 20,69 & 71,06 & 75,56 \\
\hline Peruíbe & 18,79 & 57,02 & 109,95 & 109,95 \\
\hline Praia Grande & 52,50 & 90,72 & 50,35 & 55,10 \\
\hline Santos & 15,90 & 42,35 & 44,46 & 44,46 \\
\hline São Vicente & 7,17 & 38,67 & $\mathbf{5 0 6 , 3 3}$ & $\mathbf{5 2 1 , 1 8}$ \\
\hline Total & $\mathbf{1 4 3 , 1 1}$ & $\mathbf{4 0 0 , 7 6}$ & \\
\hline
\end{tabular}


O município que apresentará a maior expansão da malha será Itanhaém, com 77,13 km, seguido de Praia Grande, com 58,03 km, e de Peruíbe com 56,77 km. Ao final de 2026, Praia Grande-SP poderá ser o município com a malha cicloviária mais extensa, com 109,95 km de vias providas de infraestrutura de apoio à circulação de bicicletas.

Além do diagnóstico da situação atual e do reconhecimento e análise de planos existentes nas Prefeituras Municipais e órgãos competentes, o PCM realizou contagens volumétricas de ciclistas, em todas as cidades da RMBS, com intuito de formular propostas de expansão da malha cicloviária. Desta forma, a pesquisa de fluxo de bicicletas, contida no Anexo 2 do PCM, coletou informações em pontos onde não havia infraestrutura de apoio ao ciclista e apresentou como resultado os seguintes itens:

- Identificação do local da pesquisa;

- Sentido da contagem;

- Dia e o horário de início e fim;

- Fluxo de bicicletas simples, com carona, com carga e a somatória de ambos.

Todas as prefeituras municipais foram contatadas pelo autor desta Tese e, como já relatado, apenas as Prefeituras de Guarujá-SP, Santos-SP e São Vicente-SP informaram quais ciclovias e/ou ciclofaixas foram implantadas entre o término das contagens volumétricas do PCM e o início da entrevista domiciliar da O/D da RMBS. A Tabela 4.15 identifica os locais onde foram implantadas e o tipo de infraestrutura nas 3 cidades da RMBS.

Tabela 4.15 - Locais e tipos de infraestrutura implantados, segundo as Prefeituras Municipais, entre o término das contagens do PCM e o início das entrevistas domiciliares

\begin{tabular}{c|c|r}
\hline Cidade & Tipo & Local \\
\hline Santos-SP & Ciclovia & Av. Alm. Saldanha entre Rua Carlos Campos e Praça Alm. Gago Coutinho \\
\hline Santos-SP & Ciclovia & Av. Afonso Pena entre a Av. Cons. Nébias e Av. Mário Covas Jr. \\
\hline Santos-SP & Ciclovia & Av. Pres. Wilson entre o Emissário Submarino e a divisa com São Vicente-SP \\
\hline São Vicente-SP & Ciclovia & Praia de Itararé entre a Ilha Porchat e a divisa com Santos-SP \\
\hline São Vicente-SP & Ciclovia & Linha Amarela entre a Praia de Itararé e Praça Álvaro Assis \\
\hline Guarujá-SP & Ciclofaixa & Av. Puglisi entre Viaduto Floriberto Mariano e R. Mário Ribeiro \\
\hline Guarujá-SP & Ciclofaixa & Av. Adhemar de Barros entre a Av. Santos Dumont e a saída da balsa \\
\hline Guarujá-SP & Ciclofaixa & Al. das Tulipas entre Av. Santos Dumont e Av. Adhemar de Barros \\
\hline Guarujá-SP & Ciclofaixa & Av. Santos Dumont entre Al. das Tulipas e Viaduto Floriberto Mariano \\
\hline Guarujá-SP & Ciclovia & Continuação na Av. Santos Dumont até a Rua Guilherme Guinle
\end{tabular}


Da Figura 4.7 até a Figura 4.15 são identificados os municípios e as respectivas ciclovias e/ou ciclofaixas existentes em 2007 (figuras sem escala). Além disso, tanto o tamanho como o número de zonas de tráfego ilustradas nas figuras, quando comparadas com as Figuras 4.1 e 4.2, diminuíram pois foram eliminadas as áreas verdes, onde não havia a presença de construções, baseado em imagens disponibilizadas pelo software Google Earth.

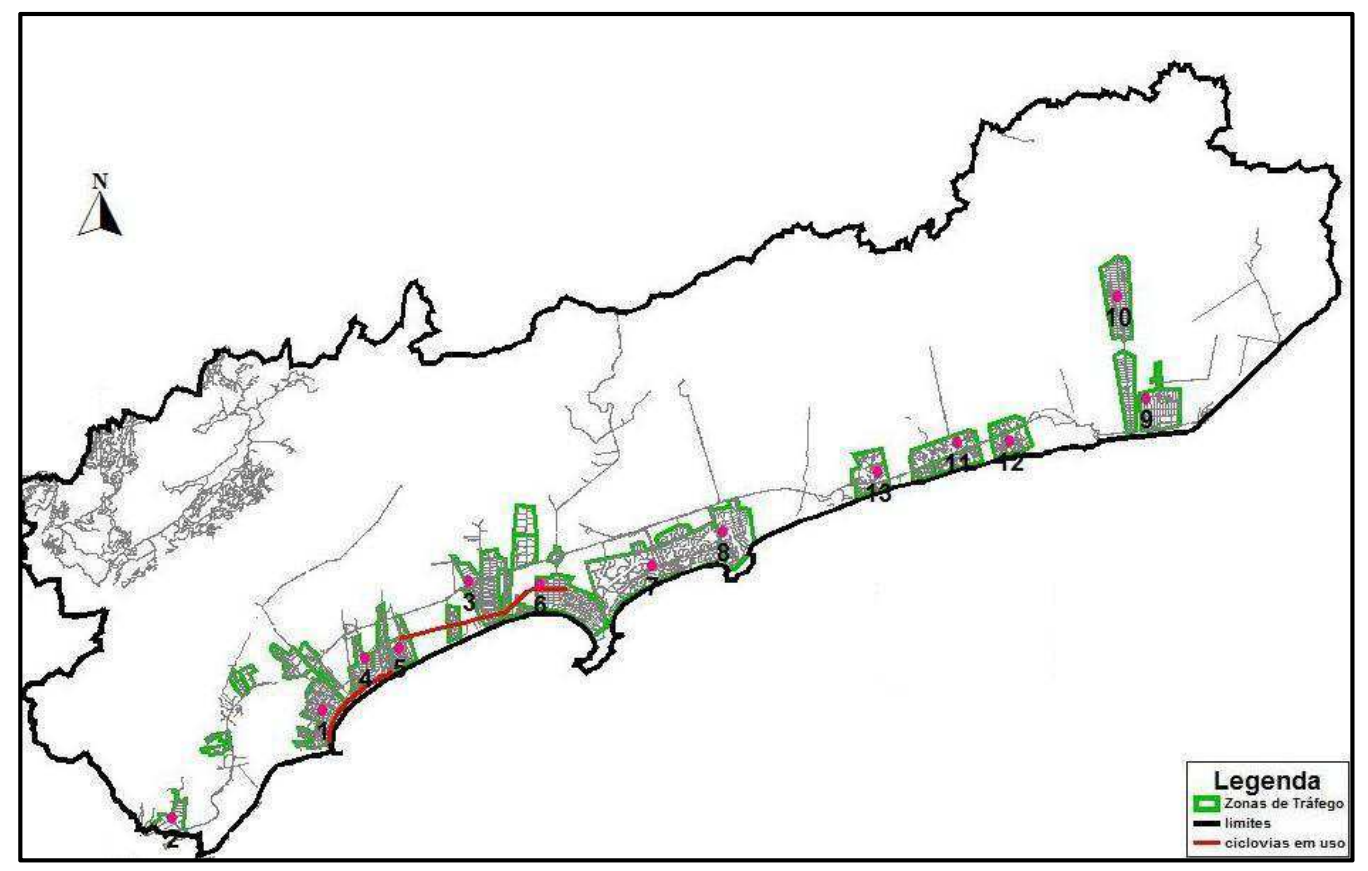

Figura 4.7 - Bertioga-SP: limites, zonas de tráfego e infraestrutura cicloviária

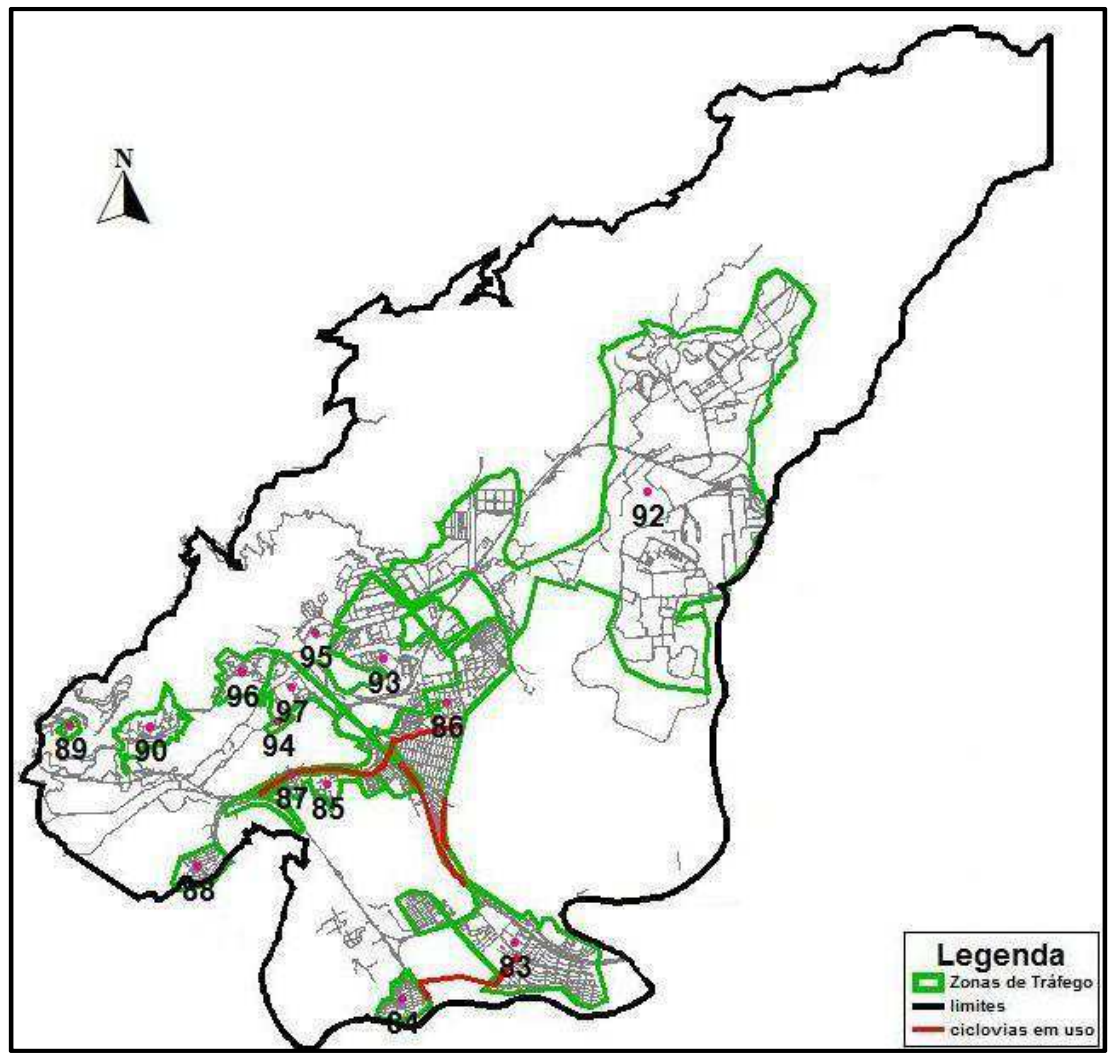

Figura 4.8 - Cubatão-SP: limites, zonas de tráfego e infraestrutura cicloviária 


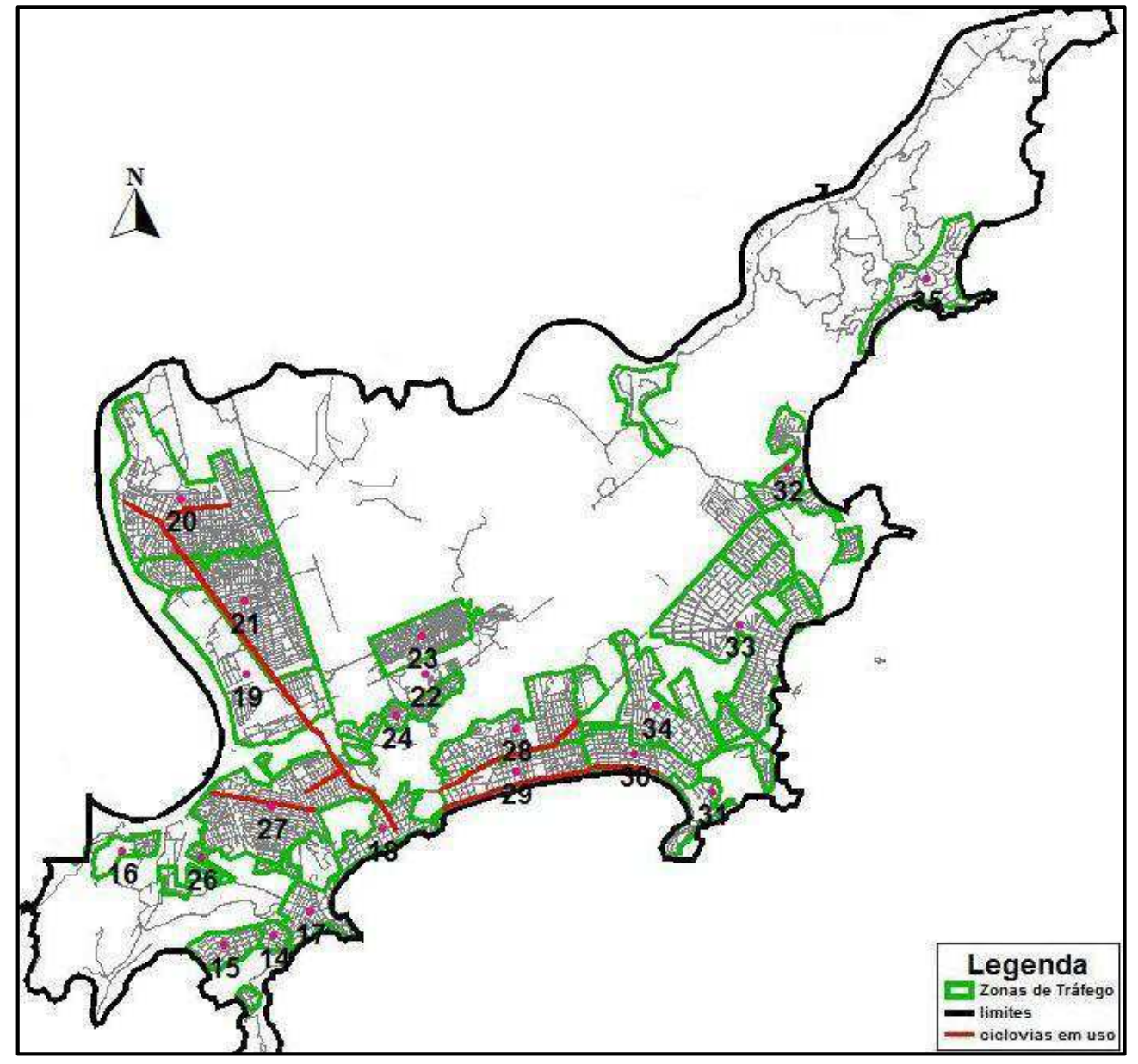

Figura 4.9 - Guarujá-SP: limites, zonas de tráfego e infraestrutura cicloviária

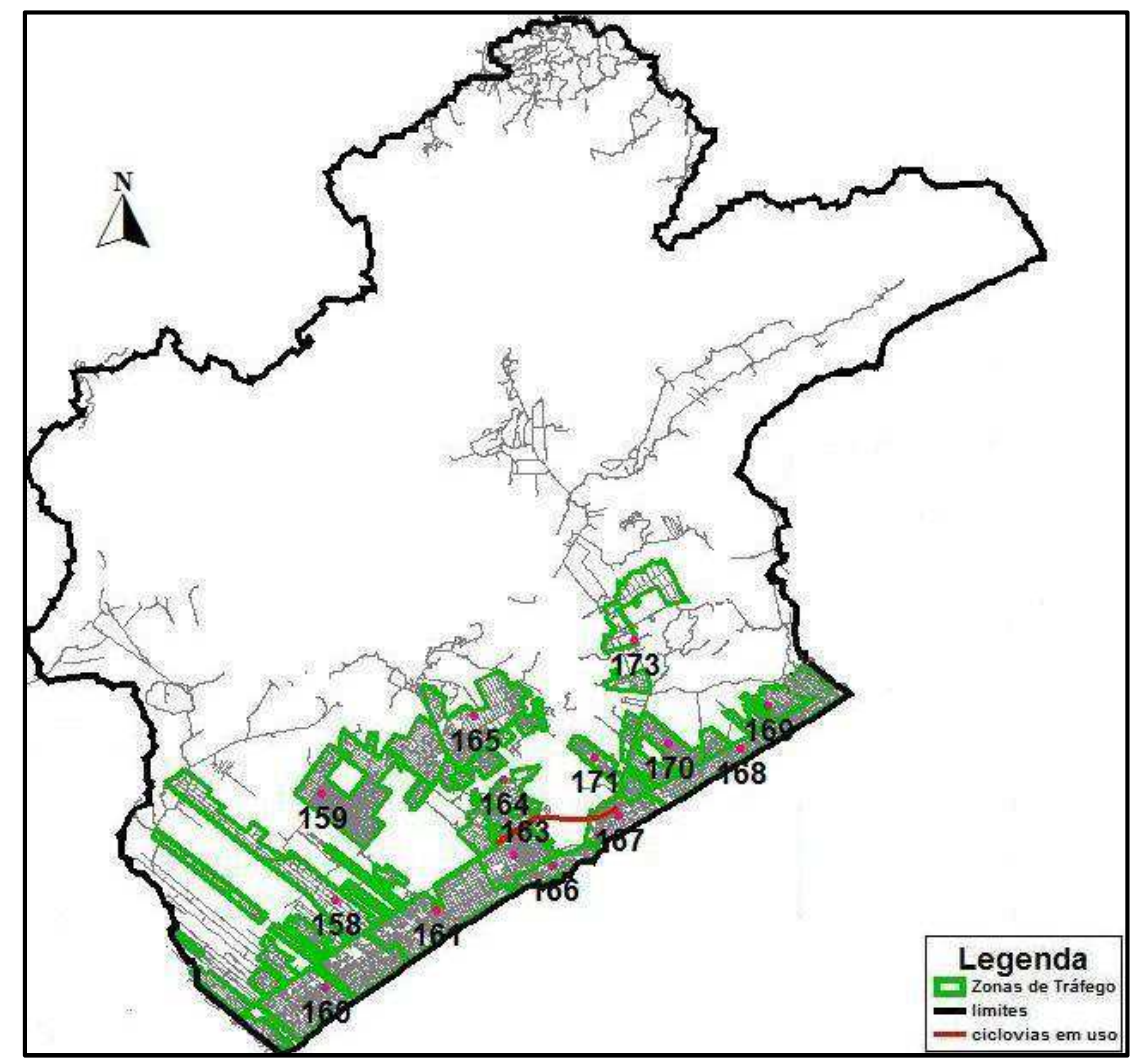

Figura 4.10 - Itanhaém-SP: limites, zonas de tráfego e infraestrutura cicloviária 


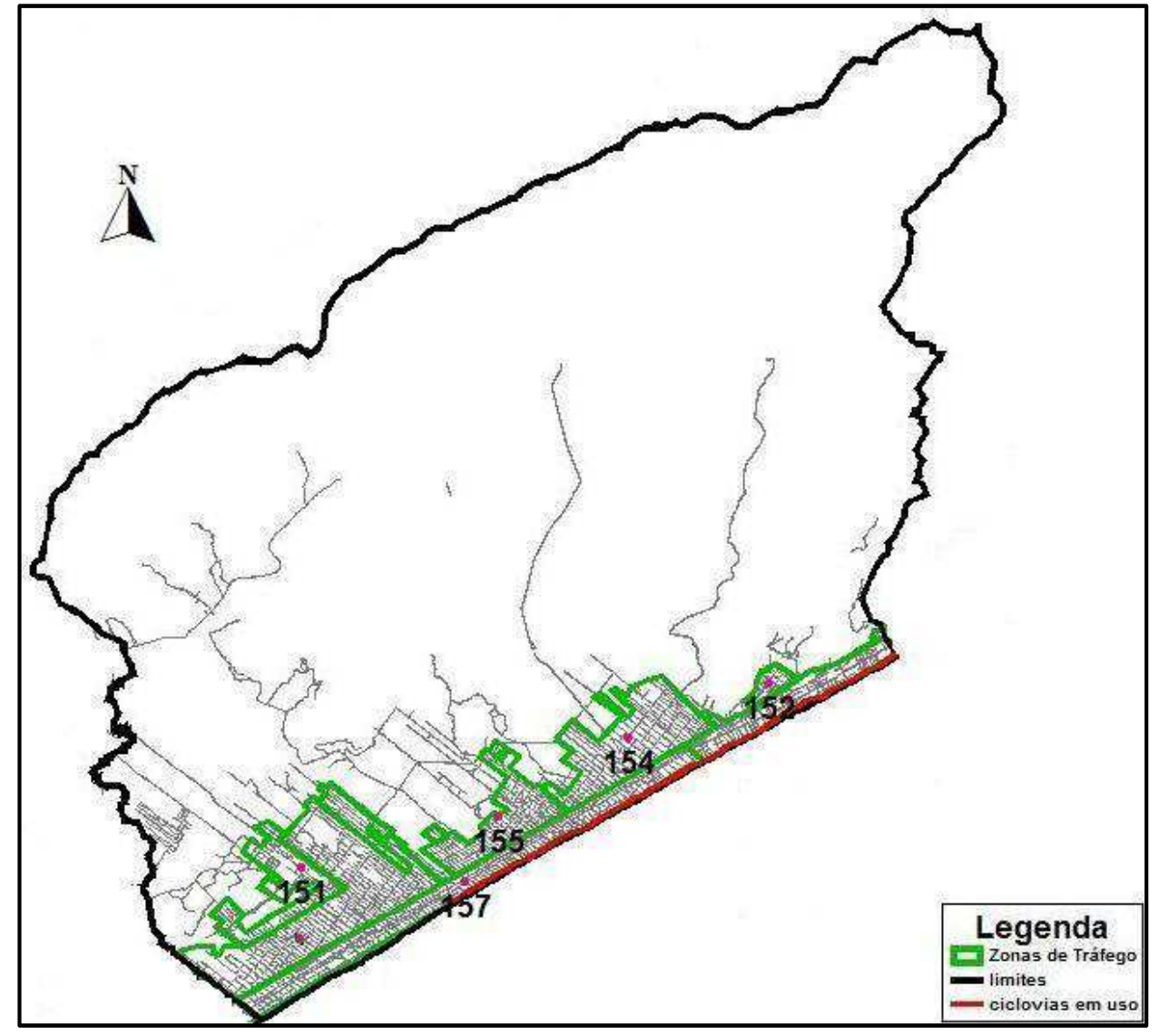

Figura 4.11 - Mongaguá-SP: limites, zonas de tráfego e infraestrutura cicloviária

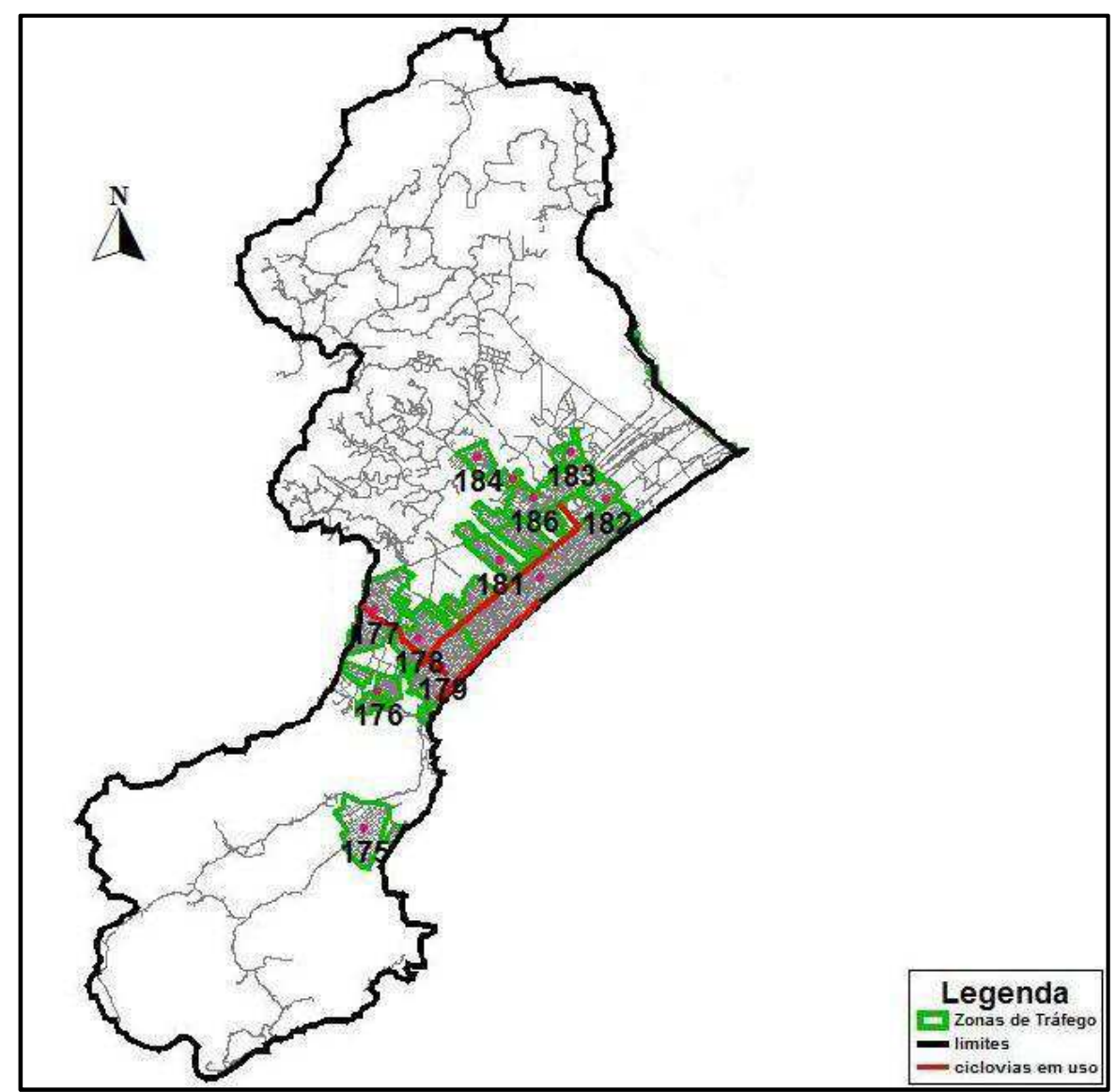

Figura 4.12 - Peruíbe-SP: limites, zonas de tráfego e infraestrutura cicloviária 


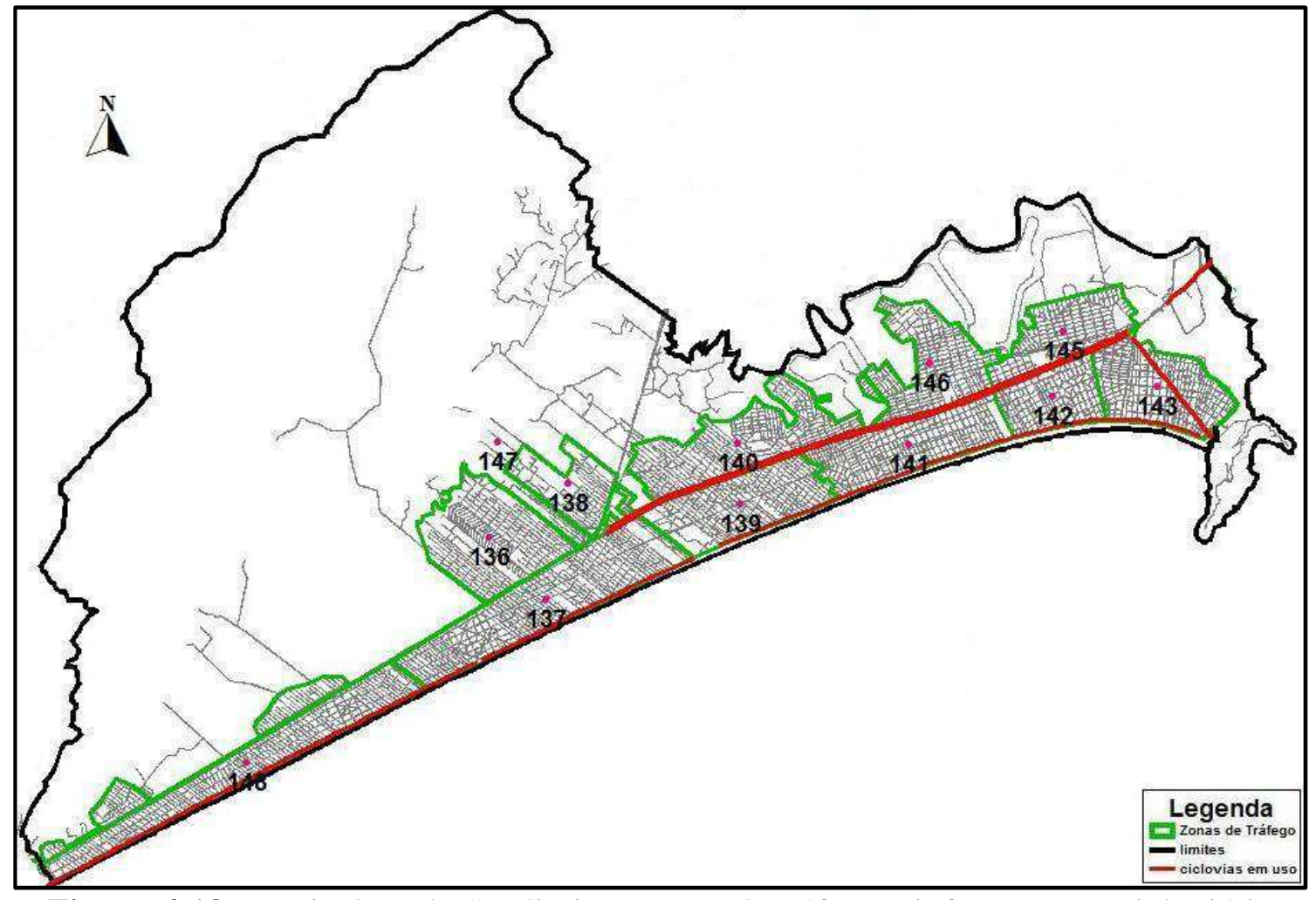

Figura 4.13 - Praia Grande-SP: limites, zonas de tráfego e infraestrutura cicloviária

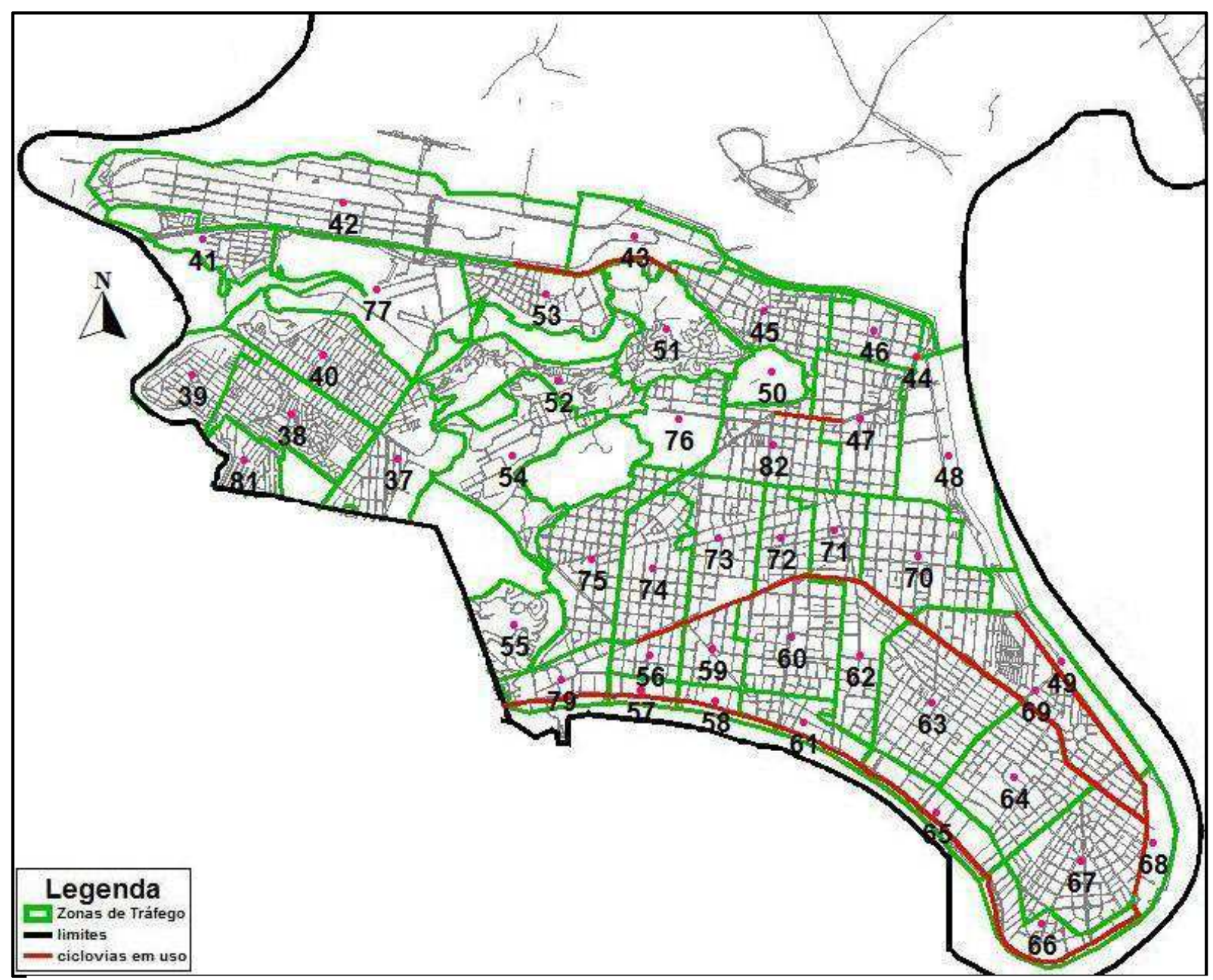

Figura 4.14 - Santos-SP: limites, zonas de tráfego e infraestrutura cicloviária 


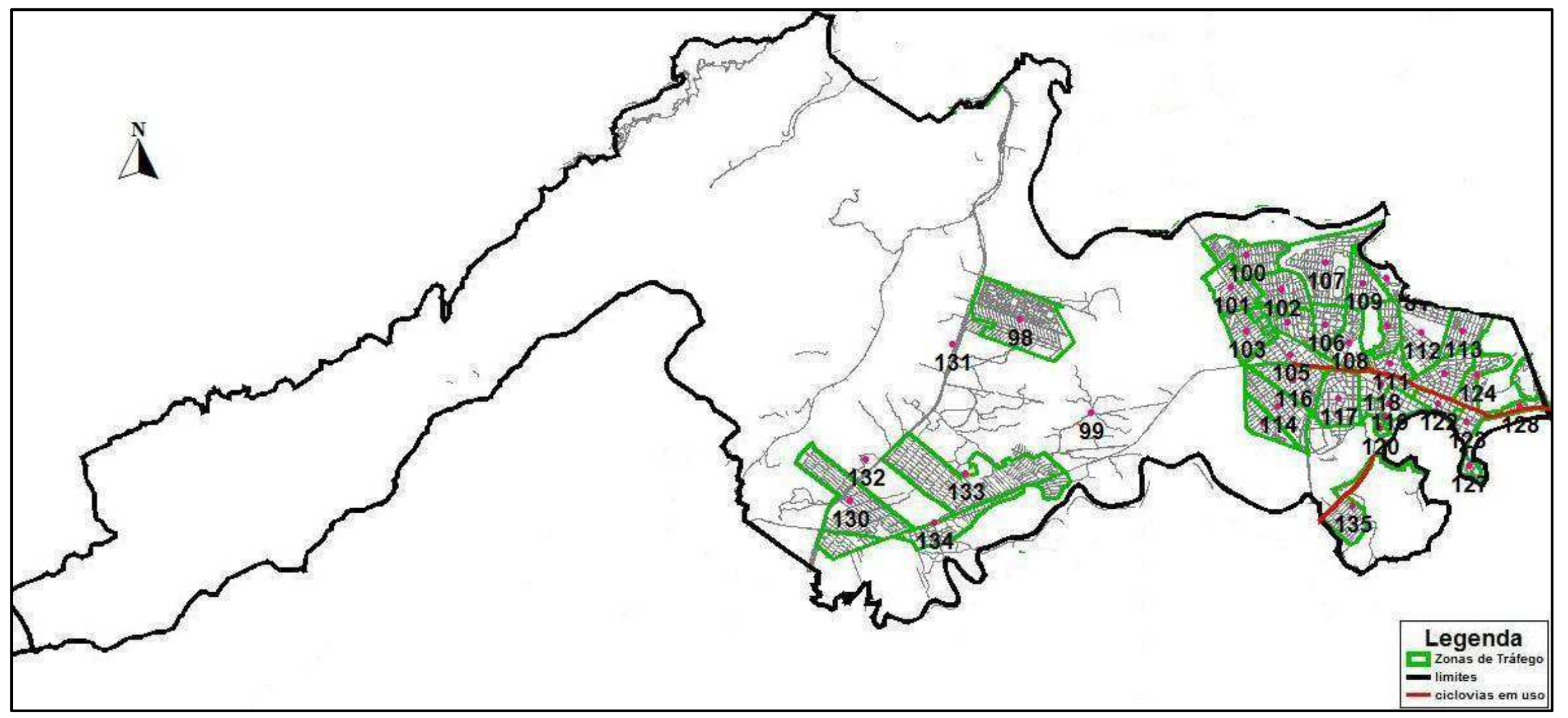

Figura 4.15 - São Vicente-SP: limites, zonas de tráfego e infraestrutura cicloviária 


\subsubsection{Caracterização Socioeconômica, de Viagens Urbanas e de Infraestrutura Cicloviária}

Nesta seção são apresentados os procedimentos, baseados nos dados provenientes da O/D (2007) e do PCM (2006), para a obtenção da caracterização das variáveis socioeconômicas, de viagens urbanas e de infraestrutura cicloviária para estimação de um modelo de escolha discreta, conforme previsto no capítulo de detalhamento do método.

\section{(i) Características Socioeconômicas}

As características socioeconômicas dos indivíduos foram representadas pela posse de automóveis no domicílio, posse de bicicletas no domicílio, renda individual e domiciliar, se trabalha ou não, setor de atividade em que atua, condição de vínculo empregatício, se estuda ou não, sexo, idade e situação familiar.

Foram expostas na seção anterior as estatísticas de frequência sobre a posse de automóveis e de bicicletas no domicílio, renda individual e domiciliar, setor de atividade em que atua, sexo, idade e situação familiar. Algumas variáveis foram rearranjadas, como as classes de renda e de idade, para diminuição do número de categorias, sem prejuízo à informação representada por elas. A Tabela 4.16 mostra a codificação das variáveis socioeconômicas envolvidas no estudo.

Tabela 4.16 - Variáveis socioeconômicas e respectivas codificações adotadas

\begin{tabular}{|c|c|c|}
\hline Item & Variável & Codificação \\
\hline 1 & Posse de automóveis & $\begin{array}{c}\text { NA1 - Até } 1 \text { automóvel } \\
\text { NA2 - Acima de } 1 \text { automóvel }\end{array}$ \\
\hline 2 & Posse de bicicleta & NBIC - Número de bicicletas no domicílio \\
\hline 3 & Renda Individual & $\begin{array}{c}\text { RI1 - Até R\$800,00 } \\
\text { RI2 - De R \$ 800,00 à R\$1.600,00 } \\
\text { RI3 - Acima de R\$ } 1.600,00\end{array}$ \\
\hline 4 & Renda Domiciliar & $\begin{array}{c}\text { RD1 - Até R\$800,00 } \\
\text { RD2 - De R \$ 800,00 à R\$1.600,00 } \\
\text { RD3 - Acima de R\$1.600,00 }\end{array}$ \\
\hline 5 & Trabalho & $\begin{array}{c}\text { T1 - Tem trabalho } \\
\text { T2 - Ocupado eventualmente / Faz "bico" } \\
\text { T3 - Em licença médica; Aposentado/Pensionista; Sem trabalho; } \\
\text { Nunca trabalhou; Dona de casa; Estudante }\end{array}$ \\
\hline
\end{tabular}


Tabela 4.16 - Variáveis socioeconômicas e respectivas codificações adotadas (continuação)

\begin{tabular}{c|c|c}
\hline Item & Variável & Codificação \\
\hline & & AT1 - Agrícola \\
& & AT2 - Construção Civil \\
& & AT3 - Indústria \\
6 & Setor de atividade & AT4 - Comércio
\end{tabular}

AT5 - Serviços de transporte de cargas; de transporte de passageiros; creditícios-financeiros; pessoais; de alimentação; de saúde; de educação; especializados; de administração pública; outros VE1 - Assalariado com carteira; Funcionário Público; Trab. doméstico com carteira; Estagiário

$7 \quad$ Vínculo Empregatício

VE2 - Assalariado sem carteira; Autonômo; Profissional Liberal; Profissional Liberal; Trab. doméstico sem carteira VE3 - Empregador; Dono de negócio familiar; Trabalhador familiar; Trab. voluntário

$$
\text { E1 - Não }
$$

E2 - Educação Infantil (Creche/Pré-escola)

E3 - Ens. Fundamental $\left(1^{\circ} \mathrm{Grau}\right)-1^{\mathrm{a}} \mathrm{à} 4^{\mathrm{a}}$ série

E4 - Ens. Fundamental $\left(1^{\circ} \mathrm{Grau}\right)-5^{\mathrm{a}}$ à $8^{\mathrm{a}}$ série

E5 - Ens. Médio ( $\left.2^{\circ} \mathrm{Grau}\right) /$ Curso Técnico

E6 - Ensino Superior / Universitário

$$
\text { E7 - Outros }
$$

\begin{tabular}{c|c|c}
\hline 9 & Sexo & Homem \\
& & Mulher \\
\hline \multirow{3}{*}{10} & Idade & ID1 - de 0 à 12 anos \\
& & ID2 - de 12 à 18 anos \\
& & ID3 - de 18 à 30 anos \\
& & ID4 - de 30 à 40 anos \\
& & ID5 - de 40 à 50 anos \\
& & ID6 - acima de 50 anos \\
\hline \multirow{3}{*}{11} & Situação Familiar & SF1 - Chefe \\
& & SF2 - Cônjuge \\
& & SF3 - Filho (a) \\
& & SF4 - Outro parente; Agregado; Empregado residente; Parente do \\
& & empregado residente \\
\hline
\end{tabular}




\section{(ii) Características das viagens urbanas}

Além das alternativas de modo de transporte consideradas no trabalho (privado, público, bicicleta e à pé), as demais características relacionadas às viagens urbanas consideradas no trabalho foram: custo monetário; gratuidade e uso do vale transportes; tempo de viagem; e distância de viagem.

\section{v.1) Custo Monetário}

Como a RMBS é composta por 9 municípios, com diferentes tarifas de transporte coletivo, foi necessário realizar o levantamento, junto às Prefeituras e à Empresa Metropolitana de Transportes Urbanos de São Paulo - EMTU/SP, acerca das tarifas, tanto em viagens intramunicipais como intermunicipais, à época da realização da entrevista domiciliar da Pesquisa O/D. Desta forma, a Tabela 4.17 mostra o custo monetário adotado, no sentido inverso também, entre as cidades e suas respectivas zonas de tráfego.

Vale ressaltar que algumas cidades não possuem linhas regulares entre si e, desta maneira, para que haja um valor hipotético da tarifa, o procedimento adotado foi a somatória de valores de tarifa, supondo que o indivíduo realize a mudança de linha de ônibus na cidade mais próxima que possua a viagem através de transporte coletivo para a cidade de destino para que, assim, pudesse chegar ao seu destino.

Por exemplo, não havia linhas regulares de Guarujá-SP para os municípios de São Vicente-SP, Praia Grande-SP, Mongaguá-SP, Itanhaém-SP e Peruíbe-SP, e o valor adotado da tarifa foi a somatória da passagem até Santos-SP, que possuía linhas regulares de ônibus para estas cidades, mais o valor da passagem até a cidade de destino. Já de São Vicente-SP não havia linhas regulares apenas para Bertioga-SP e, como já relatado, para Guarujá-SP. De Santos-SP, por ser a cidade-sede da RMBS, havia linhas intermunicipais para todas as demais cidades da RMBS. 
Tabela 4.17 - Custo monetário percebido pelos indivíduos em viagens intra e intermunicipais

\begin{tabular}{|c|c|c|}
\hline $\begin{array}{l}\text { Cidade (zonas de } \\
\text { tráfego) }\end{array}$ & Cidade (zonas de tráfego) & $\begin{array}{c}\text { Valor da tarifa em R\$ (válida } \\
\text { para o sentido inverso) }\end{array}$ \\
\hline \multirow{9}{*}{ Guarujá (14 até 36) } & Bertioga (1 até 13) & $\mathrm{R} \$ 6,50$ \\
\hline & Cubatão (83 até 97) & $\mathrm{R} \$ 5,95$ \\
\hline & Itanhaém (158 até 173) & $\mathrm{R} \$ 15,00$ \\
\hline & Mongaguá (149 até 157) & $\mathrm{R} \$ 8,50$ \\
\hline & Peruíbe (174 até 188) & $\mathrm{R} \$ 20,80$ \\
\hline & Praia Grande (136 até 148) & $\mathrm{R} \$ 5,80$ \\
\hline & Santos (37 até 82) & $\mathrm{R} \$ 2,70$ \\
\hline & São Vicente (98 até 135) & $\mathrm{R} \$ 5,80$ \\
\hline & Guarujá (14 até 36) & $\mathrm{R} \$ 2,40$ \\
\hline \multirow{9}{*}{ Santos (37 até 82) } & Bertioga (1 até 13$)$ & $\mathrm{R} \$ 2,85$ \\
\hline & Cubatão (83 até 97) & $\mathrm{R} \$ 3,10$ \\
\hline & Guarujá (14 até 36) & $\mathrm{R} \$ 2,70$ \\
\hline & Itanhaém (158 até 173) & $\mathrm{R} \$ 12,30$ \\
\hline & Mongaguá (149 até 157) & $\mathrm{R} \$ 5,80$ \\
\hline & Peruíbe (174 até 188) & $\mathrm{R} \$ 18,10$ \\
\hline & Praia Grande (136 até 148) & $\mathrm{R} \$ 3,10$ \\
\hline & São Vicente (98 até 135) & $\mathrm{R} \$ 3,10$ \\
\hline & Santos (37 até 82) & $\mathrm{R} \$ 2,50$ \\
\hline \multirow{9}{*}{ São Vicente (98 até 135) } & Bertioga (1 até 13) & $\mathrm{R} \$ 5,95$ \\
\hline & Cubatão (83 até 97) & $\mathrm{R} \$ 3,40$ \\
\hline & Guarujá (14 até 36) & $\mathrm{R} \$ 5,80$ \\
\hline & Itanhaém (158 até 173) & $\mathrm{R} \$ 9,60$ \\
\hline & Mongaguá (149 até 157) & $\mathrm{R} \$ 3,60$ \\
\hline & Peruíbe (174 até 188) & $\mathrm{R} \$ 15,80$ \\
\hline & Praia Grande (136 até 148) & $\mathrm{R} \$ 2,70$ \\
\hline & Santos (37 até 82) & $\mathrm{R} \$ 3,10$ \\
\hline & São Vicente (98 até 135) & $\mathrm{R} \$ 2,30$ \\
\hline
\end{tabular}

Para medir o custo do modo privado foi utilizada a formulação adaptada de Kawamoto e Setti (1992), onde o único custo percebido pelo indivíduo é o custo do combustível. Foi adotado o consumo de $0,3 \mathrm{~L}$, referente aos consumos de deslocamento do ponto de origem/destino até o centróide e do veículo ao sair da garagem e também estacionar, e de 7 $\mathrm{km} / \mathrm{l}$ de combustível em condições normais de tráfego urbano. A soma destes valores foi multiplicada pelo preço do combustível, cujo valor adotado foi $\mathrm{R} \$ 2,59$. Assim, a fórmula utilizada foi: 
$\mathrm{C}_{\text {privado }}=(0,3+$ Distância pela rede viária $\mathrm{x} 0,14) \mathrm{x}$ preço do combustível

\section{v.2) Gratuidade e Uso do Vale-Transporte}

No questionário utilizado na $\mathrm{O} / \mathrm{D}$ havia uma pergunta referente a quem pagou a viagem e, para quem declarou "isento", foi adotado 0 como custo do modo público. Além disso, os indivíduos acima de 65 anos e as crianças menores de 6 anos de idade foram consideradas também isentas.

Para quem declarou ser estudante, ou seja, na codificação adotada no trabalho, poderia ser de $\mathrm{E} 2$ até $\mathrm{E} 7$, foi adotado $50 \%$ de desconto na tarifa.

No caso de trabalhador com carteira assinada, pertencente às classes T1 (tem trabalho) e VE1 (assalariado com carteira, funcionário público, trab. doméstico com carteira e estagiário), segundo a codificação adotada no trabalho, se a tarifa da passagem de ônibus for maior que a renda individual multiplicada por 0,06 (6\% da renda individual) e dividida por 40 (supondo 20 dias de trabalho e utilizando duas vezes o ônibus durante o dia), foi adotado o valor da tarifa obtido através do cálculo do valor do passe do trabalhador.

\section{v.3) Tempo de Viagem}

Primeiramente, o tempo de viagem reportado na O/D referente ao modo utilizado pelo viajante foi mantido no banco de dados. Ou seja, se o indivíduo declarou que viajou de bicicleta e demorou 1 hora para chegar ao seu destino, no banco de dados, a viagem foi contabilizada para o modo "bicicleta" com o tempo de viagem igual à 1 hora. Já, para os demais modos, foram estimados valores do tempo de viagem baseados na distância percorrida pela rede viária, entre os pares de origem e destino, dividido pela velocidade média estimada para cada modo de transporte, a saber: $12,30 \mathrm{~km} / \mathrm{h}$ para o modo privado; $6,01 \mathrm{~km} / \mathrm{h}$ para o modo público; $9,24 \mathrm{~km} / \mathrm{h}$ para a bicicleta; e 4,08 km/h para o modo à pé. Vale ressaltar que todas as viagens foram compatibilizadas para a unidade de tempo "hora".

$\mathrm{Na}$ estimativa dos valores de tempo de viagem para todos os modos, exceto o modo à pé, foram somados, ao tempo declarado, os tempos de caminhada na origem e no destino coletados através do questionário da O/D. Para o modo público, além do tempo reportado e 
dos tempos de caminhada, foi somado o tempo de espera do viajante obtido através do intervalo médio entre ônibus subsequentes. Vale ressaltar que em 451 viagens que tiveram indivíduos que utilizaram o transporte escolar e o ônibus fretado, categorias pertencentes ao modo público, não foram computados o tempo de espera somado ao tempo reportado.

O tempo de espera entre ônibus subsequentes foi calculado, tanto para linhas intra quanto para intermunicipais, para cada linha de ônibus através dos horários de saída do ponto inicial. Apenas a cidade de São Vicente-SP não possuía linhas municipais de transporte coletivo regular e o sistema era operado pelo transporte alternativo feito através de vans. Desta forma, de posse do itinerário das 60 linhas intermunicipais, 40 linhas municipais em Santos e 36 linhas de Guarujá-SP, foi possível identificar por quais zonas de tráfego cada linha passava e, assim, determinar o tempo de espera médio para cada zona de tráfego.

Dependendo se o indivíduo realizava viagem intramunicipal ou intermunicipal, o tempo de espera calculado foi somado aos tempos de viagem reportado e de caminhada informados pelo viajante urbano. Vale ressaltar que, devido a proximidade de Santos-SP, que apresentou valor do tempo de espera, em média, aproximadamente igual à 8 minutos, optouse em adotar 8 minutos para quem realizava viagens intramunicipais na cidade de São Vicente-SP.

A Tabela 4.18 mostra o tempo de espera médio para cada zona de tráfego. O tempo de espera médio encontrado para as viagens intramunicipais, em todas as zonas de tráfego, foi menor do que o encontrado para as viagens intermunicipais. Ou seja, o intervalo de saída entre ônibus subsequentes, no ponto inicial das linhas intermunicipais, era maior do que nas linhas intramunicipais. Por serem viagens mais longas e também mais caras, provavelmente, não há tanto sobe e desce nas viagens intermunicipais comparado com as viagens de transporte coletivo dentro de uma mesma cidade. 
Tabela 4.18 - Tempo de espera médio nas zonas de tráfego para viagens intra e intermunicipais

\begin{tabular}{|c|c|c|c|c|c|c|c|c|c|c|c|}
\hline Cidade & Zt's & $\begin{array}{c}T_{\text {espera }} \text { em min } \\
\text { (viagens } \\
\text { intramunicipais) }\end{array}$ & $\begin{array}{c}T_{\text {espera }} \text { em min } \\
\text { (viagens } \\
\text { intermunicipais) }\end{array}$ & Cidade & Zt's & $\begin{array}{c}T_{\text {espera }} \text { em min } \\
\text { (viagens } \\
\text { intramunicipais) }\end{array}$ & $\begin{array}{c}T_{\text {espera }} \text { em min } \\
\text { (viagens } \\
\text { intermunicipais) }\end{array}$ & Cidade & Zt's & $\begin{array}{c}T_{\text {espera }} \text { em min } \\
\text { (viagens } \\
\text { intramunicipais) }\end{array}$ & $\begin{array}{c}T_{\text {espera }} \text { em min } \\
\text { (viagens } \\
\text { intermunicipais) }\end{array}$ \\
\hline \multirow{23}{*}{ Guarujá } & 14 & 10,9 & 11,5 & \multirow{23}{*}{ Santos } & 37 & 7,3 & 11,5 & \multirow{23}{*}{ Santos } & 60 & 8,2 & 10,6 \\
\hline & 15 & 10,6 & 11,5 & & 38 & 7,3 & 11,5 & & 61 & 7,8 & 10,4 \\
\hline & 16 & 7,5 & 11,5 & & 39 & 7,1 & 11,7 & & 62 & 7,7 & 10,6 \\
\hline & 17 & 11,3 & 11,5 & & 40 & 7,3 & 11,5 & & 63 & 8,5 & 10,7 \\
\hline & 18 & 10,2 & 12,8 & & 41 & 8,0 & 10,6 & & 64 & 8,5 & 10,7 \\
\hline & 19 & 10,9 & 11,4 & & 42 & 8,0 & 11,1 & & 65 & 7,9 & 10,2 \\
\hline & 20 & 10,9 & 11,4 & & 43 & 8,0 & 10,7 & & 66 & 7,6 & 10,6 \\
\hline & 21 & 10,9 & 11,4 & & 44 & 8,0 & 10,5 & & 67 & 7,9 & 10,6 \\
\hline & 22 & 11,1 & 15,3 & & 45 & 8,0 & 10,5 & & 68 & 7,9 & 10,2 \\
\hline & 23 & 11,1 & 12,5 & & 46 & 8,3 & 9,3 & & 69 & 8,3 & 10,7 \\
\hline & 24 & 11,3 & 12,5 & & 47 & 8,5 & 10,1 & & 70 & 8,2 & 10,7 \\
\hline & 25 & 10,5 & 11,5 & & 48 & 7,7 & 10,3 & & 71 & 8,7 & 10,4 \\
\hline & 26 & 10,4 & 11,7 & & 49 & 8,0 & 10,5 & & 72 & 7,8 & 10,9 \\
\hline & 27 & 10,5 & 11,4 & & 50 & 8,2 & 11,2 & & 73 & 7,3 & 10,5 \\
\hline & 28 & 10,5 & 11,7 & & 51 & 7,7 & 10,7 & & 74 & 8,0 & 10,4 \\
\hline & 29 & 10,6 & 11,7 & & 52 & 7,4 & 11,4 & & 75 & 7,8 & 10,7 \\
\hline & 30 & 11,3 & 11,5 & & 53 & 7,4 & 10,7 & & 76 & 7,9 & 10,3 \\
\hline & 31 & 12,7 & 11,5 & & 54 & 6,9 & 10,7 & & 77 & 7,4 & 10,8 \\
\hline & 32 & 11,1 & 11,5 & & 55 & 7,5 & 10,7 & & 78 & 7,5 & 10,7 \\
\hline & 33 & 11,3 & 11,5 & & 56 & 9,0 & 10,7 & & 79 & 9,0 & 10,4 \\
\hline & 34 & 10,8 & 11,5 & & 57 & 8,6 & 10,5 & & 80 & 8,0 & 12,1 \\
\hline & 35 & 9,5 & 11,5 & & 58 & 7,8 & 10,2 & & 81 & 8,0 & 9,5 \\
\hline & 36 & 10,9 & 11,9 & & 59 & 8,3 & 10,8 & & 82 & 7,8 & 10,5 \\
\hline
\end{tabular}


Tabela 4.18 - Tempo de espera médio nas zonas de tráfego para viagens intra e intermunicipais (continuação)

\begin{tabular}{|c|c|c|c|c|c|c|c|c|c|c|c|}
\hline Cidade & Zt's & $\begin{array}{c}T_{\text {espera }} \text { em min } \\
\text { (viagens } \\
\text { intramunicipais) }\end{array}$ & $\begin{array}{c}T_{\text {espera }} \text { em min } \\
\text { (viagens } \\
\text { intermunicipais) }\end{array}$ & Cidade & Zt's & $\begin{array}{c}T_{\text {espera }} \text { em min } \\
\text { (viagens } \\
\text { intramunicipais) }\end{array}$ & $\begin{array}{c}T_{\text {espera }} \text { em min } \\
\text { (viagens } \\
\text { intermunicipais) }\end{array}$ & Cidade & Zt's & $\begin{array}{c}T_{\text {espera }} \text { em min } \\
\text { (viagens } \\
\text { intramunicipais) }\end{array}$ & $\begin{array}{c}T_{\text {espera }} \text { em min } \\
\text { (viagens } \\
\text { intermunicipais) }\end{array}$ \\
\hline \multirow{14}{*}{$\begin{array}{c}\text { São } \\
\text { Vicente }\end{array}$} & 98 & 8,0 & 10,4 & \multirow{14}{*}{$\begin{array}{c}\text { São } \\
\text { Vicente }\end{array}$} & 112 & 8,0 & 11,3 & \multirow{14}{*}{$\begin{array}{c}\text { São } \\
\text { Vicente }\end{array}$} & 126 & 8,0 & 10,7 \\
\hline & 99 & 8,0 & 10,4 & & 113 & 8,0 & 11,3 & & 127 & 8,0 & 11,0 \\
\hline & 100 & 8,0 & 10,4 & & 114 & 8,0 & 10,7 & & 128 & 8,0 & 10,5 \\
\hline & 101 & 8,0 & 12,5 & & 115 & 8,0 & 10,0 & & 129 & 8,0 & 12,6 \\
\hline & 102 & 8,0 & 10,5 & & 116 & 8,0 & 11,1 & & 130 & 8,0 & 11,4 \\
\hline & 103 & 8,0 & 12,1 & & 117 & 8,0 & 10,6 & & 131 & 8,0 & 10,9 \\
\hline & 104 & 8,0 & 10,3 & & 118 & 8,0 & 10,4 & & 132 & 8,0 & 11,8 \\
\hline & 105 & 8,0 & 11,1 & & 119 & 8,0 & 10,5 & & 133 & 8,0 & 11,2 \\
\hline & 106 & 8,0 & 9,4 & & 120 & 8,0 & 9,8 & & 134 & 8,0 & 11,3 \\
\hline & 107 & 8,0 & 9,8 & & 121 & 8,0 & 10,7 & & 135 & 8,0 & 11,0 \\
\hline & 108 & 8,0 & 9,4 & & 122 & 8,0 & 10,5 & & & & \\
\hline & 109 & 8,0 & 10,5 & & 123 & 8,0 & 10,5 & & & & \\
\hline & 110 & 8,0 & 10,5 & & 124 & 8,0 & 10,4 & & & & \\
\hline & 111 & 8,0 & 9,5 & & 125 & 8,0 & 11,6 & & & & \\
\hline
\end{tabular}




\section{v.4) Distância de Viagem}

Como a pesquisa O/D não foi georreferenciada, foi necessário supor que todas as viagens tiveram os centróides das zonas de tráfego como origem e destino. Acredita-se que este procedimento não afetou significativamente o resultado da pesquisa, pois, poderia haver tanto viagens com origem e destino próximos ao limite adjacente, que separa as zonas de tráfego, ou o contrário, em limites longínquos. Vale ressaltar que a RMBS, localizada em uma área limitada em 2 direções, seja pela Serra do Mar ou pelo Oceano Atlântico, possui características longilíneas que podem resultar em distâncias de viagem maiores do que em cidades sem qualquer restrição de ordem geográfica.

Outro procedimento previsto, no detalhamento do método, foi a eliminação de áreas verdes não habitadas existentes na RMBS. A eliminação destas áreas nas zonas de tráfego poderá resultar em distâncias de viagem mais próximas da realidade já que, a maioria das viagens, devem ser originadas e destinadas aos núcleos com presença de vias de acesso e construções diversas.

Com a adoção da distância de viagem entre centróides foi necessário eliminar 1614 viagens intrazonais. Desta forma, o banco de dados que continha 11.067 viagens, passou a ter 9.453 viagens urbanas. A Tabela 4.19, já atualizada com a eliminação das viagens intrazonais e de quem declarou que usou o modo "Outros" na O/D, mostra a frequência dos atributos relacionados ao sexo e situação familiar e a respectiva distância de viagem pela rede viária.

Tabela 4.19 - Atributos de sexo e situação familiar, respectivas frequências e percentuais, relacionados com as distâncias médias de viagem pela rede viária

\begin{tabular}{c|c|c|c}
\hline Atributo & $\begin{array}{c}\text { Frequência } \\
\text { de Viagens }\end{array}$ & $\%$ & $\begin{array}{c}\text { Distância Média de Viagem } \\
\text { (pela rede viária, em km) }\end{array}$ \\
\hline Sexo & & & \\
\hline Homem & 5425 & 57,76 & 7,14 \\
\hline Mulher & 3968 & 42,24 & 7,57 \\
\hline Situação Familiar & & & 8,82 \\
\hline Chefe & 4018 & 42,78 & 7,99 \\
\hline Cônjuge & 1656 & 17,63 & 8,52 \\
\hline Filho (a) & 2937 & 31,27 & 7,66 \\
\hline Outro parente & 682 & 7,26 & 7,33 \\
\hline Agregado & 90 & 0,96 & 5,24 \\
\hline Empregado residente & 4 & 0,04 & \\
\hline Outros & 6 & 0,06 & \\
\hline
\end{tabular}




\section{iii) Caracterização da Infraestrutura Cicloviária}

Como já dito no Capítulo 3, a caracterização da infraestrutura cicloviária foi baseada na rota de tempo mínimo entre os centróides de origem e destino da viagem. Para definição da rota, foram adotados os valores de velocidade, em $\mathrm{km} / \mathrm{h}$, para os trechos sem e com infraestrutura cicloviária $(7,50 \mathrm{~km} / \mathrm{h}$ e $16,02 \mathrm{~km} / \mathrm{h}$, respectivamente $)$, baseado no tempo reportado na O/D e nas distâncias percorridas em vias junto ao tráfego de veículos e em vias com a presença de ciclovias e/ou ciclofaixas. Tais valores foram obtidos no banco de dados em viagens onde o ciclista, muito provavelmente, não utilizou, a infraestrutura cicloviária e vice-versa.

Desta forma, a rota que levou o menor tempo, entre os centróides de origem e destino, baseada em velocidades e nas distâncias percorridas, dentro e fora da infraestrutura cicloviária, foi utilizada para a construção do indicador de infraestrutura cicloviária.

Como se trata da relação entre distância percorrida em ciclovias e/ou ciclofaixas dividida pela distância total entre os centróides de origem e destino, os valores do indicador sempre foram maiores para os indivíduos que utilizaram a rota com a maior presença de infraestrutura cicloviária. Ressalta-se que, caso o valor do indicador seja próximo de 1, a rota utilizada pelo viajante é quase totalmente feita em ciclovias e/ou ciclofaixas.

Após realizar o procedimento de adoção das velocidades para determinar qual a rota seria mais vantajosa, em relação ao tempo gasto para se chegar ao destino, foi obtido o percentual de 60,40\% para a rota com maior trecho em ciclovias e/ou ciclofaixas e 39,60\% pela rota de menor caminho, independentemente da presença ou não de infraestrutura cicloviária. Assim, na maioria dos casos, os viajantes urbanos prefeririam desviar da rota de menor caminho para utilizar a infraestrutura de apoio ao ciclista. 


\section{CAPÍTULO 5}

\section{EXPERIMENTO}

봅

\subsection{Considerações Iniciais}

Conforme previsto no Capítulo 3, nesta seção será estimado o modelo de escolha discreta com a utilização de variáveis socioeconômicas, de viagens urbanas e do indicador de infraestrutura cicloviária. Posteriormente, será construído o cenário 1, em que será comparado o resultado do modelo de escolha discreta com o número de viagens de bicicleta expandido, obtido da O/D nos pontos de contagem onde, anteriormente, não havia infraestrutura cicloviária. Caso o modelo reproduza adequadamente o número de viagens de bicicleta expandido, será realizada a construção do cenário 2, que irá comparar o resultado do modelo, para o ano de 2006, com os dados de contagem volumétrica registrados no PCM.

A hipótese do trabalho, de que é possível identificar e quantificar fatores, através do modelo de escolha discreta, que influem na escolha do modo cicloviário será testada e verificada através da significância estatística dos parâmetros estimados. Além disso, a consistência das relações entre variáveis independentes e a escolha do modo será alvo de análise.

E a hipótese secundária, de que estes fatores servirão como instrumento de apoio, para gestores públicos, na avaliação e no planejamento da tomada de decisão para implantação de ciclovias e/ou ciclofaixas, será verificada e discutida após comparação dos resultados do 
modelo de escolha discreta com os números de viagens de bicicleta nos pontos de contagem, tanto para o cenário 1 como para o 2.

Vale ressaltar que, no capítulo seguinte, serão discutidos tanto os resultados da especificação do modelo de escolha discreta como a utilização do modelo para a previsão da demanda em alguns pontos da RMBS, através dos cenários 1 e 2 .

\subsection{Especificação do Modelo de Escolha Discreta e Resultado}

Esta seção descreve o modelo logit multinomial obtido para estimar as probabilidades individuais de escolha do modo de viagem na RMBS. Para a estimação do modelo foram utilizadas as informações das características socioeconômicas, de viagens urbanas e de infraestrutura cicloviária já descritas no capítulo anterior.

Foram consideradas 4 alternativas de escolha do modo de viagem, a saber: (1) Privado; (2) Público; (3) Bicicleta; (4) a pé. Os modos a pé, bicicleta e ônibus foram considerados disponíveis para toda a população do banco de dados. Já o modo privado foi considerado disponível para quem realmente o utilizou e, para os demais casos, indisponível caso não houvesse automóvel no domicílio.

Inicialmente, as funções utilidade foram estimadas através de 47 parâmetros que correspondem as variáveis de interesse descritas no capítulo anterior. A verificação feita através da consistência da relação entre os parâmetros estimados e escolha do modo, da significância estatística dos parâmetros e da correlação entre os coeficientes das funções utilidade serviu para rearranjá-las e, desta forma, estimá-las de acordo com as equações (10) até (13).

$U_{\text {privado }}=A S C_{1}+\beta_{\text {tempo de viagem }} x$ Tprivado $+\beta_{\text {custo de viagem }} x$ Cprivado $+\beta_{N A 1} x$ Ncarl $+\beta_{N A 2} x$ $N c a r 2+\beta_{S F 1} x S F 1$

Em que:

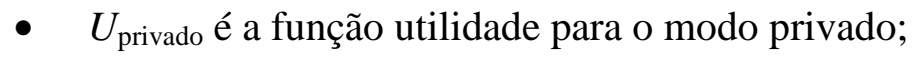

- $\quad A S C_{1}$ é a constante específica do modo privado; 
- $\quad \beta_{\text {tempo de viagem }}$ é o parâmetro estimado da variável contínua referente ao tempo de viagem através do modo privado;

- Tprivado é a variável contínua referente ao tempo de viagem gasto pelo modo privado;

- $\quad \beta_{\text {custo de viagem }}$ é o parâmetro estimado da variável contínua referente ao custo de viagem através do modo privado;

- Cprivado é a variável contínua referente ao custo de viagem através do modo privado;

- $\quad \beta_{N A l}$ é o parâmetro estimado da variável dummy referente à presença de 1 automóvel no domicílio;

- Ncarl é a variável dummy referente à presença (1- sim; 0- não) de 1 automóvel no domicílio;

- $\quad \beta N A 2$ é o parâmetro estimado da variável dummy referente à presença de mais de 1 automóvel no domicílio;

- Ncar2 é a variável dummy referente à presença (1- sim; 0- não) de mais de 1 automóvel no domicílio;

- $\quad \beta S F 1$ é o parâmetro estimado da variável dummy referente à situação familiar "Chefe";

- SF1 é a variável dummy referente a pertencer (1- sim; 0- não) à situação familiar "Chefe".

$U_{\text {público }}=A S C_{2}+\beta_{\text {tempo de viagem }} x$ Tpúblico $+\beta_{\text {custo de viagem }} x$ Cpúblico $+\beta_{V E 2} x$ VE2 $2+\beta_{V E 3} x$

$V E 3+\beta_{R D 1} \times R D 1+\beta_{R D 2} x R D 2$

Em que:

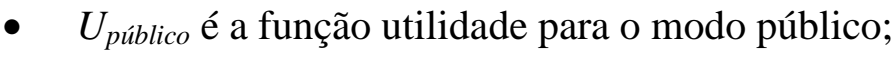

- $\quad A S C_{2}$ é a constante específica do modo público;

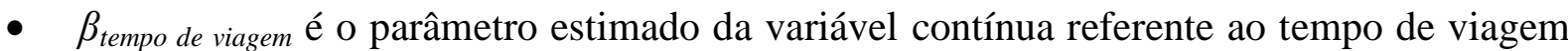
através do modo público;

- Tpúblico é a variável contínua referente ao tempo de viagem gasto pelo modo público;

- $\quad \beta_{\text {custo de viagem }}$ é o parâmetro estimado da variável contínua referente ao custo de viagem através do modo público;

- Cpúblico é a variável contínua referente ao custo de viagem através do modo público;

- $\quad \beta_{V E 2}$ é o parâmetro estimado da variável dummy referente a pertencer à categoria assalariado sem carteira, autônomo ou profissional liberal;

- VE2 é a variável dummy referente a pertencer (1- sim; 0- não) à categoria assalariado sem carteira, autônomo ou profissional liberal; 
- $\quad \beta_{V E 3}$ é o parâmetro estimado da variável dummy referente a pertencer à categoria empregador, dono de negócio familiar, trabalhador familiar ou voluntário;

- VE3 é a variável dummy referente a pertencer (1- sim; 0- não) à categoria empregador, dono de negócio familiar, trabalhador familiar ou voluntário;

- $\quad \beta_{R D 1}$ é o parâmetro estimado da variável dummy referente a pertencer à categoria de renda domiciliar de 0 até $\mathrm{R} \$ 800,00$;

- $\quad$ RD1 é a variável dummy referente a pertencer (1- sim; 0- não) à categoria de renda domiciliar de 0 até $\mathrm{R} \$ 800,00$;

- $\quad \beta_{R D 2}$ é o parâmetro estimado da variável dummy referente a pertencer à categoria de renda domiciliar de $\mathrm{R} \$ 800,00$ até $\mathrm{R} \$ 1.600,00$;

- $\quad R D 2$ é a variável dummy referente a pertencer (1- sim; 0- não) à categoria de renda domiciliar de de $\mathrm{R} \$ 800,00$ até $\mathrm{R} \$ 1.600,00$;

$U_{\text {bicicleta }}=A S C_{3}+\beta_{\text {tempo de viagem }} \times$ Tbicicleta $+\beta_{A T 2} x A T 2+\beta_{A T 3} x A T 3+\beta_{A T 5} x A T 5+\beta_{\text {sexo }} x$ sexo $+\beta_{I D 2} x I D 2+\beta_{I D 7} x I D 7+\beta_{N B I C} x N B I C+\beta_{I N D} x I N D$

Em que:

- $U_{\text {bicicleta }}$ é a função utilidade para o modo bicicleta;

- $\quad \mathrm{ASC}_{3}$ é a constante específica do modo bicicleta;

- $\quad \beta_{\text {tempo de viagem }}$ é o parâmetro estimado da variável contínua referente ao tempo de viagem através do modo bicicleta;

- Tbicicleta é a variável contínua referente ao tempo de viagem gasto pelo modo bicicleta;

- $\quad B_{A T 2}$ é o parâmetro estimado da variável dummy referente ao indivíduo pertencer ao setor de atividade da Construção Civil;

- $\quad$ AT2 é a variável dummy referente ao indivíduo pertencer (1- sim; 0- não) ao setor de atividade da Construção Civil;

- $\quad B_{A T 3}$ é o parâmetro estimado da variável dummy referente ao indivíduo pertencer ao setor de atividade da Indústria;

- $\quad$ AT3 é a variável dummy referente ao indivíduo pertencer (1- sim; 0- não) ao setor de atividade da Indústria;

- $\quad B_{A T 5}$ é o parâmetro estimado da variável dummy referente ao indivíduo pertencer ao setor de atividade de Serviços; 
- $\quad$ AT5 é a variável dummy referente ao indivíduo pertencer (1- sim; 0- não) ao setor de atividade de Serviços;

- $B_{\text {sexo }}$ é o parâmetro estimado da variável dummy referente ao indivíduo ser do sexo masculino ou feminino;

- Sexo é a variável dummy referente ao indivíduo ser do sexo masculino (1) ou feminino $(0)$;

- $\quad B_{I D 2}$ é o parâmetro estimado da variável dummy referente ao indivíduo pertencer à categoria de idade compreendida entre 12 e 18 anos;

- ID2 é a variável dummy referente ao indivíduo pertencer (1- sim; 0- não) à categoria de idade compreendida entre 12 e 18 anos;

- $\quad B_{I D 7}$ é o parâmetro estimado da variável dummy referente ao indivíduo pertencer à categoria de idade compreendida entre 18 e 50 anos;

- ID7 é a variável dummy referente ao indivíduo pertencer (1- sim; 0- não) à categoria de idade compreendida entre 18 e 50 anos;

- $\quad B_{N B I C}$ é o parâmetro estimado da variável contínua referente ao número de bicicletas no domicílio;

- $\quad$ NBIC é a variável contínua referente ao número de bicicletas no domicílio;

- $\quad B_{I N D}$ é o parâmetro estimado da variável contínua referente ao indicador de infraestrutura cicloviária;

- IND é a variável contínua referente ao indicador de infraestrutura cicloviária.

$U_{a p e ́}=A S C_{4}+\beta_{\text {tempo de viagem }} x$ Tà pé $+\beta_{E 4} x E 4$

Em que:

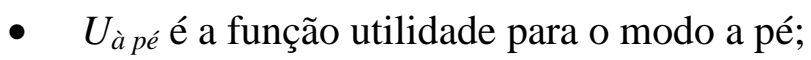

- $A S C_{4}$ é a constante específica do modo a pé;

- $\quad \beta_{\text {tempo de viagem }}$ é o parâmetro estimado da variável contínua referente ao tempo de viagem através do modo a pé;

- Ta pé é a variável contínua referente ao tempo de viagem gasto pelo modo a pé;

- $B_{E 4}$ é o parâmetro estimado da variável dummy referente ao indivíduo pertencer à categoria do ensino fundamental $\left(1^{\mathrm{o}}\right.$ grau $-5^{\mathrm{a}}$ à $8^{\mathrm{a}}$ série $)$;

- E4 é a variável dummy referente ao indivíduo pertencer (1- sim; 0- não) à categoria do ensino fundamental ( $1^{\mathrm{o}}$ grau $-5^{\mathrm{a}}$ à $8^{\mathrm{a}}$ série $)$. 
As categorias ID3, ID4 e ID5 da variável Idade, utilizada na função do modo bicicleta, foram agrupadas pois os respectivos coeficientes encontrados pelo modelo foram praticamente idênticos. Desta forma, foi criada a categoria ID7, que compreendeu as pessoas com idade entre 18 e 50 anos.

Na Tabela 5.1 são apresentados os valores dos parâmetros das funções utilidade de cada alternativa de modo de transporte e os respectivos valores da estatística $t$ que, no caso, foram significativos em nível de 5\%.

Tabela 5.1 - Estimativa do modelo logit multinomial para escolha do modo

\begin{tabular}{|c|c|c|}
\hline Parâmetros da Função Utilidade & Valor & Estatística $t$ \\
\hline \multicolumn{3}{|l|}{ Constantes } \\
\hline Privado & 0,00 & - \\
\hline Público & 1,72 & $(14,70)$ \\
\hline Bicicleta & $-0,98$ & $(-6,44)$ \\
\hline À pé & 2,22 & $(24,74)$ \\
\hline \multicolumn{3}{|l|}{ Tempo de Viagem } \\
\hline Privado & $-1,14$ & $(-12,66)$ \\
\hline Público & $-0,65$ & $(-14,43)$ \\
\hline Bicicleta & $-2,30$ & $(-24,99)$ \\
\hline À pé & $-3,69$ & $(-30,75)$ \\
\hline \multicolumn{3}{|l|}{ Custo de Viagem } \\
\hline Privado & $-0,164$ & $(-6,80)$ \\
\hline Público & $-0,178$ & $(-4,08)$ \\
\hline \multicolumn{3}{|l|}{ Privado } \\
\hline NA1 - Número de automóveis igual a 1 & 1,74 & $(30,68)$ \\
\hline NA2 - Número de automóveis maior que 1 & 3,19 & $(27,59)$ \\
\hline SF1 - Indivíduo é chefe de família & 0,621 & $(11,18)$ \\
\hline \multicolumn{3}{|l|}{ Público } \\
\hline VE2 - Assalariado sem carteira, autônomo ou profissional liberal & $-0,421$ & $(-7,37)$ \\
\hline $\begin{array}{l}\text { VE3 - Categoria de empregador, dono de negócio familiar, } \\
\text { trabalhador familiar ou voluntário }\end{array}$ & $-0,899$ & $(-5,31)$ \\
\hline RD1 - Renda domiciliar de 0 até $\mathrm{R} \$ 800,00$ & $-0,579$ & $(-4,84)$ \\
\hline $\mathrm{RD} 2$ - Renda domiciliar de $\mathrm{R} \$ 800,00$ até $\mathrm{R} \$ 1.600,00$ & $-0,292$ & $(-4,01)$ \\
\hline \multicolumn{3}{|l|}{ Bicicleta } \\
\hline AT2 - Trabalha na Construção Civil & 1,36 & $(9,87)$ \\
\hline
\end{tabular}


Tabela 5.1 - Estimativa do modelo logit multinomial para escolha do modo (cont.)

\begin{tabular}{|c|c|c|}
\hline Parâmetros da Função Utilidade & Valor & Estatística $\mathbf{t}$ \\
\hline AT3 - Trabalha na Indústria & $-0,985$ & $(-3,30)$ \\
\hline AT5 - Trabalha em Serviços & $-0,488$ & $(-6,38)$ \\
\hline Sexo - Homem ou Mulher & 1,28 & $(15,22)$ \\
\hline ID2 - Idade entre 12 e 18 anos & 0,483 & $(1,97)$ \\
\hline ID7 - Idade entre 18 e 50 anos & 0,251 & $(2,27)$ \\
\hline IND - Indicador de dotação de infraestrutura cicloviária & 0,302 & $(2,96)$ \\
\hline NBIC - Número de bicicletas no domicílio & 0,537 & $(17,45)$ \\
\hline \multicolumn{3}{|l|}{$\grave{A} p e ́$} \\
\hline E4 - Pertence ao ensino fundamental $\left(1^{\circ}\right.$ grau $-5^{\mathrm{a}}$ à $8^{\mathrm{a}}$ série $)$ & 1,37 & $(3,98)$ \\
\hline
\end{tabular}

$\mathrm{Na}$ Tabela 5.2 são apresentadas as medidas de desempenho do modelo logit multinomial estimado para o cálculo das probabilidades individuais para a escolha modal.

Tabela 5.2 - Estatística do modelo logit multinomial para escolha do modo

\begin{tabular}{c|c}
\hline Estatística do Modelo & Valor \\
\hline Parâmetros estimados & 25 \\
\hline Observações & 9393 \\
\hline$L L\left(\beta^{\prime}=0\right)$ & $-13.021,463$ \\
\hline$L L\left(\beta^{\prime}=\beta^{\prime \prime}\right)$ & $-8.088,505$ \\
\hline$\rho$ & 0,379 \\
\hline
\end{tabular}

Como não há limites para se afirmar qual é o índice para determinar o melhor, ou pior, desempenho do modelo, a simples confrontação com os índices existentes mostra que a medida de desempenho do modelo gerado para a RMBS está situada dentro da faixa dos valores encontrados na literatura. De acordo com valores de $\rho$, mostrados por Silva (2011), o índice de razão de verossimilhança está situado dentro dos índices de trabalhos encontrados na literatura sobre modelos de escolha de modos de transportes, realizados a partir de pesquisas de preferência revelada.

\subsection{Cenário 1}

O primeiro cenário construído serviu para estimar a demanda cicloviária através do modelo de escolha discreta e pelas viagens da O/D feitas de bicicleta que passaram pelos 
pontos de contagem volumétrica de ciclistas. Estes pontos, entre 2006 e 2007, receberam infraestrutura cicloviária, segundo informações das Prefeituras Municipais de Guarujá-SP, Santos-SP e São Vicente-SP. A construção deste cenário foi necessária para que pudesse ser avaliada, para o ano de 2007, a utilidade do modelo para reproduzir a quantidade de viagens de bicicleta após a implantação de infraestrutura cicloviária na RMBS.

Vale ressaltar que nos pontos de contagem volumétrica de ciclistas, segundo as prefeituras, foram construídas ciclovias ou ciclofaixas bidirecionais. No entanto, por questões de representatividade estatística, o experimento considerou a soma da demanda cicloviária observada nos dois sentidos pois o volume de contagem em cada sentido, no intervalo de 10 minutos, é relativamente baixo em alguns casos.

Após a estimação do modelo feita na seção anterior, o passo seguinte foi a seleção de viagens da O/D. Inicialmente, com auxílio do TransCAD, foi calculado o tempo gasto entre a origem (centróides da zona de tráfego) e os pontos de contagem, para cada viagem, seja através do modo privado, público, bicicleta ou a pé, utilizando o horário de início da viagem somado com o tempo gasto para chegar até o ponto de contagem. Para calcular este tempo, foram utilizadas as velocidades de 7,50 km/h, em distâncias percorridas fora da infraestrutura de apoio ao ciclista, e de $16,02 \mathrm{~km} / \mathrm{h}$, em caso contrário, e o total foi somado ao horário de início da viagem.

Assim, foi possível saber se o viajante passaria, ou não, dentro do intervalo de uma hora da contagem volumétrica. Foram contabilizadas somente as viagens que, com a soma do tempo gasto com o horário de início da viagem, estiveram inclusas no intervalo compreendido de 1 hora.

É importante frisar que as viagens realizadas pelos modos alternativos de viagem considerados, que passaram pelo ponto de contagem, foram consideradas no cálculo da quantidade de viagens pelo modelo de escolha discreta. Desta forma, pode haver pares $\mathrm{O} / \mathrm{D}$, por exemplo, com viagens através de todas as alternativas exceto pelo modo bicicleta. Como o modelo logit multinomial calcula a probabilidade individual de cada alternativa de modo de transporte, independentemente da pessoa utilizar ou não o modo, a somatória destas probabilidades, multiplicadas pelo respectivo fator de expansão, resulta no número real de indivíduos que passaram pelo ponto de contagem. 
Da seleção das viagens da O/D realizadas por todas as alternativas de modo nos pontos de contagem, foram extraídas somente as viagens de bicicleta que, após serem expandidas, serviram para comparação com os resultados do modelo de escolha discreta.

A maioria das contagens volumétricas de ciclistas registradas no PCM foram feitas em intervalos de 10 minutos e, para compatibilizar todas as contagens para a unidade de tempo "hora", optou-se por multiplicar por 6 as contagens que duraram 10 minutos. Ressalta-se que o procedimento supõe que o intervalo é repetido, identicamente, ao longo dos 6 períodos de 10 minutos da hora, o que pode não ocorrer na prática. Nos casos em que a contagem era de 10 minutos, foi definido que o intervalo dentro de uma hora (em que os 10 minutos estavam inseridos) que continha mais viagens seria utilizado para seleção das viagens da O/D.

A Tabela 5.3 descreve a localização dos pontos de contagem volumétrica de ciclistas e os respectivos horários considerados na análise. Vale salientar que a nomenclatura adotada identifica o tipo de infraestrutura implantada, do tipo ciclovia ou ciclofaixa, e que o número, em seguida, foi meramente aleatório e serviu apenas para diferenciar os pontos.

Tabela 5.3 - Pontos de contagem e as respectivas localizações e intervalos horários

\begin{tabular}{c|c|c|c}
\hline Nomenclatura & Cidade & Localização & Intervalo (hs) \\
\hline Ciclovia 1 & Santos-SP & $\begin{array}{c}\text { Av. Alm. Saldanha da Gama (próximo da balsa da } \\
\text { travessia Santos-SP/Guarujá-SP) }\end{array}$ & $17: 56-18: 56$ \\
\hline Ciclovia 2 & Santos-SP & Av. Afonso Pena (próximo da Av. Alm. Cochrane) & $6: 02-7: 02$ \\
\hline Ciclovia 3 & Santos-SP & Av. Pres. Wilson (próximo do Emissário Submarino) & $16: 55-17: 55$ \\
\hline Ciclovia 4 & São Vicente-SP & Av. Ayrton Senna (Praia de Itararé) & $17: 20-18: 20$ \\
\hline Ciclovia 5_M & São Vicente-SP & Linha Amarela (entre a Av. Antonio Emmerich e o & $7: 15-8: 15$ \\
\hline Ciclovia 5_T & São Vicente-SP & Linha Amarela (entre Av. Monteiro Lobato e Av. & $17: 32-18: 32$ \\
\hline Ciclofaixa 6 & Guarujá-SP & Padre Manoel da Nóbrega) & $17: 30-18: 30$ \\
\hline Ciclofaixa 7 & Guarujá-SP & Av. Adhemar de Barros (próximo da balsa da travessia & $6: 00-7: 00$ \\
\hline Ciclofaixa 8 & Guarujá-SP & Al. das Tulipas (próximo da Av. Santos Dumont) & $6: 00-7: 00$ \\
\hline Ciclofaixa 9 & Guarujá-SP & Av. Santos Dumont (próximo do Viaduto Floriberto & $6: 00-7: 00$ \\
\hline
\end{tabular}


Por exemplo, as contagens de 10 minutos nos pontos Ciclovia 10 e Ciclovia 5_M foram feitas nos horários de 19:20 até às 19:30hs e 8:05 até às 8:15hs, respectivamente. Se estes horários representassem o pico da hora-pico, deveriam ser considerados os intervalos de uma hora compreendidos entre 18:55 e 19:55hs, para o ponto Ciclovia 10, e 7:40 e 8:40hs, para o ponto Ciclovia 5_M. No entanto, como não é possível saber se o intervalo de 10 minutos considerado pela equipe executora da contagem representa o fluxo máximo de ciclistas que passou pelos pontos de contagem no pico, o intervalo de uma hora foi adotado a partir do maior número de viagens, nos dois sentidos, determinados pela Pesquisa O/D. Nestes dois casos, o intervalo teve término no minuto final da contagem de 10 minutos (18:30-19:30hs e 7:15-8:15hs, respectivamente).

Desta forma, de posse da localização dos pontos de contagem localizados nas ciclovias e/ou ciclofaixas implantadas e dos intervalos de uma hora, foi possível selecionar as viagens na O/D da RMBS. Vale salientar que os pontos Ciclovia 5_M e Ciclovia 5_T estavam localizados na Av. Martins Fontes, também chamada de Linha Amarela, e que os pontos Ciclofaixa 6 e Ciclovia 10 foram os únicos pontos em que a contagem volumétrica, segundo o PCM, durou exatamente 1 hora.

A Tabela 5.4 mostra os resultados da estimação da demanda cicloviária pelo modelo e pelas viagens expandidas feitas de bicicleta que passaram pelos pontos de contagem. Informações sobre o número de viagens selecionadas e os respectivos valores aproximados dos fatores médios de expansão, para ambas previsões, também são mostrados na tabela. A diferença percentual entre as duas previsões é mostrada na última coluna.

É possível perceber que na coluna (4), referente ao número de viagens selecionadas de bicicleta, a amostra das viagens que passaram pelos pontos de contagem variou entre 10 viagens, para o ponto Ciclofaixa 9, e 28 viagens, para o ponto Ciclofaixa 7, respectivamente.

Nos pontos Ciclovia 3, Ciclovia 4, Ciclovia 5_T e Ciclofaixa 9, caso houvesse maior número de viagens selecionadas de bicicleta (coluna 4), a diferença entre as duas estimativas seria menor. Se por um lado a amostra pode ser considerada pequena para expansão dos dados e posterior comparação com os resultados através do modelo logit multinomial, por outro lado, poderia ser considerada suficiente caso houvesse menos viagens, como nos pontos Ciclofaixa 8, Ciclovia 1 e Ciclofaixa 6, respectivamente. 
Tabela 5.4 - Pontos de contagem e resultados pelo modelo Logit Multinomial e pelo número de viagens expandidas de bicicleta

\begin{tabular}{c|c|c|c|c|c|c|c}
\hline \multirow{2}{*}{ Ponto } & \multicolumn{3}{|c|}{ Modelo Logit Multinomial } & \multicolumn{3}{c|}{ Viagens expandidas de bicicleta } & Fator \\
\cline { 2 - 7 } & $\begin{array}{c}\mathbf{N}^{\mathbf{0}} \text { de viagens } \\
\text { selecionadas }\end{array}$ & $\begin{array}{c}\text { Fator } \\
\text { médio de } \\
\text { expansão } \\
\mathbf{( 2 )}\end{array}$ & $\begin{array}{c}\text { Previsão da } \\
\text { demanda }\end{array}$ & $\begin{array}{c}\mathbf{N}^{\mathbf{0}} \text { de viagens } \\
\text { selecionadas }\end{array}$ & $\begin{array}{c}\text { Previsa da } \\
\text { médio de } \\
\text { demanda } \\
\text { expansão } \\
\mathbf{( 5 )}\end{array}$ & $\begin{array}{c}\mathbf{( 3 )} \\
\text { versus } \\
\mathbf{( 6 )}\end{array}$ \\
\hline Ciclovia 1 & 73 & 57 & 979 & 20 & 59 & 1135 & $-15,93$ \\
\hline Ciclovia 2 & 75 & 55 & 968 & 14 & 66 & 935 & 3,53 \\
\hline Ciclovia 3 & 150 & 80 & 1414 & 17 & 71 & 1212 & 16,67 \\
\hline Ciclovia 4 & 216 & 59 & 1182 & 17 & 65 & 1060 & 11,51 \\
\hline Ciclovia 5_M & 133 & 54 & 854 & 16 & 54 & 857 & $-0,35$ \\
\hline Ciclovia 5_T & 180 & 53 & 955 & 15 & 50 & 745 & 28,19 \\
\hline Ciclofaixa 6 & 48 & 73 & 544 & 15 & 47 & 708 & $-30,15$ \\
\hline Ciclofaixa 7 & 101 & 56 & 1155 & 28 & 49 & 1164 & $-0,78$ \\
\hline Ciclofaixa 8 & 80 & 60 & 1105 & 23 & 56 & 1251 & $-13,21$ \\
\hline Ciclofaixa 9 & 47 & 52 & 503 & 10 & 41 & 427 & 17,80 \\
\hline Ciclovia 10 & 80 & 74 & 1061 & 16 & 68 & 1028 & 3,21 \\
\hline Totais & - & - & $\mathbf{1 0 7 2 0}$ & - & - & $\mathbf{1 0 5 2 2}$ & $\mathbf{1 , 8 8}$ \\
\hline
\end{tabular}

Já os pontos Ciclovia 2, Ciclovia 5_M, Ciclofaixa 7 e Ciclovia 10 apresentaram diferenças percentuais muito próximas, inferiores a 4\%, entre as previsões de demanda cicloviária pelo modelo de escolha discreta (coluna 3) e o número de viagens expandidas de bicicleta (coluna 6). Comparando os totais de previsão, a diferença percentual é igual a $1,88 \%$.

Qualquer Pesquisa Origem e Destino está sujeita à aleatoriedade como, por exemplo, os domicílios entrevistados, em uma determinada zona de tráfego da RMBS que utiliza a rota que passa pelos pontos de contagem, continham viajantes ciclistas. Já em outra zona, ocasionalmente, as entrevistas domiciliares não contemplaram os ciclistas da zona em questão. Além disso, a amostra dos domicílios entrevistados representou aproximadamente $1,5 \%$ do total de domicílios da RMBS.

Desta forma, para o Cenário 1, as diferenças entre as duas estimativas foram causadas pelo fato de que o número de viagens selecionadas da $\mathrm{O} / \mathrm{D}$ foi pequeno e não permite ter certeza das estimativas do número de ciclistas que passaram pelos pontos de contagem, seja usando a contagem direta da Pesquisa O/D (previsão mostrada na coluna 6), seja usando o 
modelo de escolha discreta aplicado à amostra relativamente pequena (previsão mostrada na coluna 3).

Apesar das diferenças devido ao pequeno número de viagens, a máxima diferença entre as previsões foi de $30,15 \%$ e em cerca de 4 pontos foi inferior à $4 \%$. Portanto, admite-se que o modelo reproduziu adequadamente o número de viagens expandidas de bicicleta e, em sequência, será construído o Cenário 2 que irá ou não corroborar com as hipóteses desta Tese.

De acordo com a sequência do Método, presente na Figura 5.1, caso o modelo reproduzisse adequadamente o número de viagens de bicicleta expandidas, seria construído o Cenário 2. Este cenário contemplaria a comparação da previsão da demanda através do modelo de escolha discreta com dados de contagem volumétrica de ciclistas registrados no PCM para o ano de 2006. Assim, a comparação seria feita com dados reais de contagem de ciclistas nos pontos para 2006.

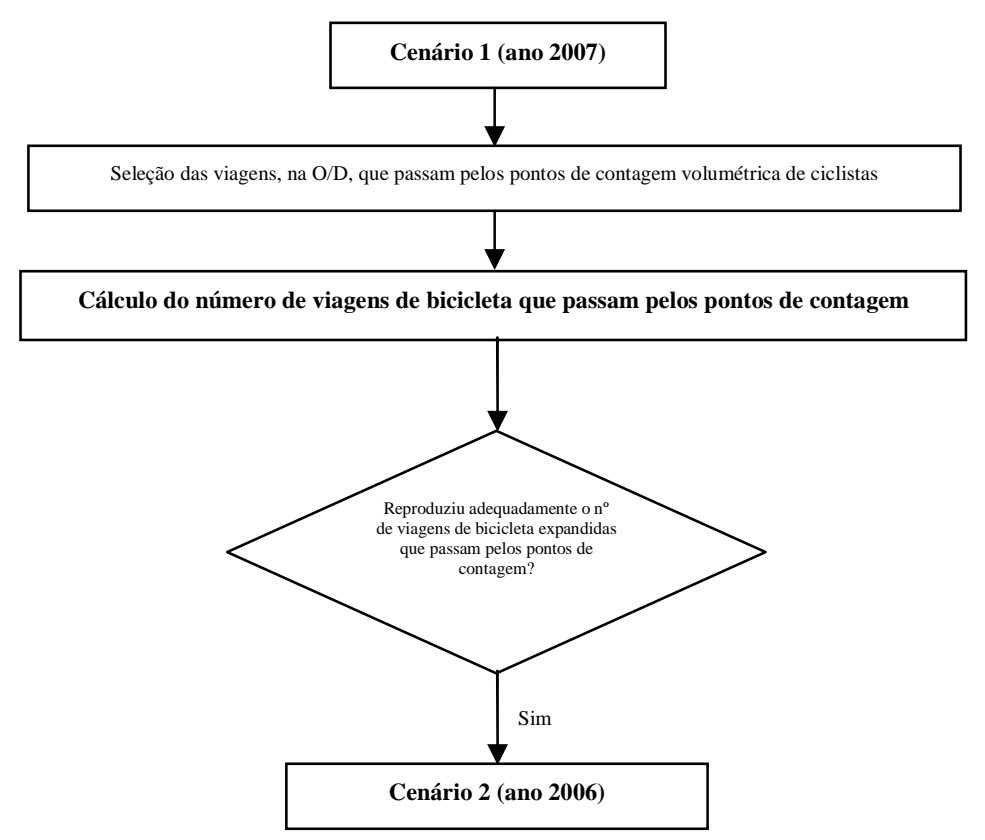

Figura 5.1 - Sequência do Método caso o modelo de escolha discreta reproduza adequadamente o número de viagens de bicicleta no Cenário 1 


\subsection{Cenário 2}

A comparação prevista no Cenário 2, inicialmente, só foi possível após a análise de quais variáveis utilizadas na função utilidade da bicicleta tiveram mudanças significativas no intervalo compreendido entre as contagens volumétricas registradas no PCM, feitas em 2006, e a realização das entrevistas domiciliares da Pesquisa O/D da RMBS, iniciadas em 2007. A função obtida foi:

$U_{\text {bicicleta }}=-0,98_{(-6,44)}-2,30_{(-24,99)} \times$ Tbicicleta $+1,36_{(9,87)} \times A T 2-0,985_{(-3,30)} \times A T 3-0,488_{(-6,38)}$ $x$ AT5 + 1,28 $8_{(15,22)} x$ sexo $+0,483_{(1,97)} x I D 2+0,251_{(2,27)} x I D 7+0,537_{(17,45)} x$ NBIC + $0,302_{(2,96)} \times I N D$

Em que:

- $\quad U_{\text {bicicleta }}$ é a função utilidade para o modo bicicleta;

- Tbicicleta é a variável contínua referente ao tempo de viagem gasto pelo modo bicicleta;

- $\quad$ AT2 é a variável dummy referente ao setor de atividade da Construção Civil;

- $\quad$ AT3 é a variável dummy referente ao setor de atividade da Indústria;

- $\quad$ AT5 é a variável dummy referente ao setor de atividade de Serviços;

- Sexo é a variável dummy referente à pessoa ser homem ou mulher;

- ID2 é a variável dummy referente à categoria de idade compreendida entre 12 e 18 anos;

- ID7 é a variável dummy referente à categoria de idade compreendida entre 18 e 50 anos;

- $\quad N B I C$ é a variável contínua referente ao número de bicicletas no domicílio;

- IND é a variável contínua referente ao indicador de infraestrutura cicloviária.

As variáveis AT2, que representa os indivíduos que trabalham na construção civil; NBIC, que indica o número de bicicletas no domicílio; e o IND, que diz respeito ao indicador de infraestrutura cicloviária; foram consideradas variáveis que sofreram modificações no referido período.

Já as variáveis que dizem respeito ao exercício de atividades na indústria e no setor de serviços, devido a difícil obtenção de dados que pudessem comprovar as respectivas modificações e, além disso, serem atividades pontuais que demandam área de construção e tempo para serem instaladas, foram consideradas sem mudanças significativas no intervalo de 
1 ano entre as contagens volumétricas do PCM e a realização das entrevistas domiciliares da Pesquisa O/D da RMBS. As demais variáveis, Sexo e Idade, não mudaram no referido período.

Segundo a Pesquisa Anual da Indústria da Construção (IBGE, 2007), tanto o número de empresas como o número de pessoas ocupadas no setor da construção civil aumentou entre os anos de 2006 e 2007. A Tabela 5.5 mostra o crescimento no Brasil, na Região Sudeste e no estado de São Paulo do número de empresas e do número de pessoas entre 2006 e 2007.

Tabela 5.5 - Crescimento percentual do número de empresas da construção civil, entre os anos de 2006 e 2007, no Brasil, Região Sudeste e Estado de São Paulo

\begin{tabular}{c|c|c|c|c|c|c}
\hline \multirow{2}{*}{ Unidade } & \multicolumn{2}{|c|}{2006} & \multicolumn{2}{c}{2007} & \multicolumn{2}{c}{ Crescimento (\%) } \\
\cline { 2 - 7 } & Empresas & Pessoas & Empresas & Pessoas & Empresas & Pessoas \\
\hline Brasil & 109.140 & 1.541 .628 & 110.303 & 1.812 .254 & 1,07 & 17,55 \\
\hline Região Sudeste & 51.683 & 835.715 & 52.546 & 1.014 .231 & 1,67 & 21,36 \\
\hline São Paulo * & 8.315 & 380.100 & 8.483 & 456.474 & 2,02 & 20,09 \\
\hline
\end{tabular}

Fonte: Pesquisa Anual da Indústria da Construção, v. 17 (IBGE, 2007)

* Dados do Estado de São Paulo para empresas com 5 ou mais pessoas ocupadas

Segundo o DIEESE (2011), até o ano de 2003, o cenário da construção civil nacional vivenciou um período de instabilidade, caracterizado pela falta de incentivo, pela tímida disponibilidade de recursos e por uma inexpressiva presença de financiamento imobiliário. A partir de 2004 o setor mostrou sinais de expansão, com o aumento dos investimentos em infraestrutura e em unidades habitacionais, inclusive superando as taxas negativas de crescimento, em 2009, em função da crise econômico-financeira internacional.

O resultado mostrado na Tabela 5.5 é reflexo do crescimento da construção civil no Brasil, especificamente, no Estado de São Paulo. Desta forma, quando da realização das contagens volumétricas do PCM em 2006, é possível afirmar que havia menos pessoas trabalhando na construção civil do que no ano de 2007. Como, no Estado de São Paulo, a taxa de crescimento foi de aproximadamente $20 \%$ entre os anos subsequentes, e como havia a identificação dos indivíduos pertencentes ao setor de atividade da construção civil no banco de dados da RMBS (variável AT2), foi possível estimar quantas pessoas, a menos, pertenciam ao referido setor na época da contagem do PCM. Para tanto, bastou dividir por 1,20 o valor do fator de expansão dos indivíduos pertencentes ao setor de atividade da construção civil. 
Vale ressaltar que dados como o número de alvarás de construção expedidos pelas Prefeituras Municipais foram solicitados, porém, não atendidos em tempo hábil para serem incluídos no trabalho ora desenvolvido.

Outra variável que variou no intervalo compreendido entre as duas pesquisas foi o número de bicicletas no domicílio. Supõe-se que, a partir da construção de ciclovias e/ou ciclofaixas, as pessoas que moram nas proximidades ou que utilizam a rota, que recebeu a infraestrutura de apoio ao ciclista, passam a adquirir a bicicleta para realizar as viagens do dia-a-dia.

Para capturar a variação do número de bicicletas no domicílio, inicialmente, foram obtidos modelos de regressão que, porém, não conseguiram prever satisfatoriamente o número de bicicletas. Posteriormente, através da utilização da Árvore de Decisão e Classificação contida no Software SPlus 8.0, e utilizando como variável resposta o número de bicicletas no domicílio e como variável preditora a variável IND, referente ao indicador da infraestrutura cicloviária, foi possível detectar os valores médios de bicicletas no domicílio em função do indicador, conforme mostra a Figura 5.2.

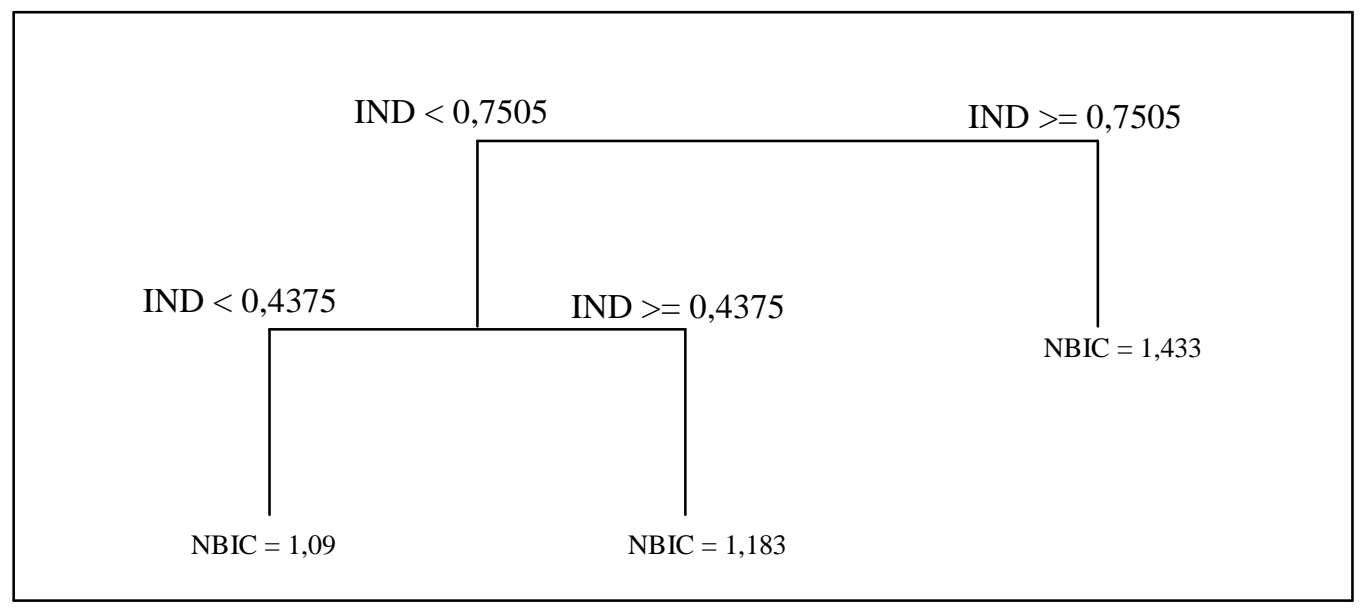

Figura 5.2 - Resultado da Árvore de Decisão e Classificação para obtenção do número médio de bicicletas no domicílio (NBIC)

Foram adotados os critérios de número mínimo de observações por nó terminal igual a 500 e desvio mínimo de 0,5 em relação ao nó principal. O resultado mostrou que há variação do número de bicicletas no domicílio a partir do maior ou menor uso da infraestrutura de apoio ao ciclista nas viagens urbanas. Por exemplo, se a viagem do indivíduo possuir indicador superior, ou igual, a 0,7505, ou seja, 75,05\% feita sobre ciclovias e/ou ciclofaixas, o 
número médio de bicicletas no domicílio é de 1,433. Já se for entre 75,05\% e 43,75\%, o número cai para 1,183 e, se for abaixo de $43,75 \%$, passa a ser 1,09 bicicletas por domicílio.

Desta forma, sabendo-se que o indicador de infraestrutura cicloviária era menor na época das contagens do PCM, pois não havia ciclovias e/ou ciclofaixas nos pontos de contagem, optou-se pelo procedimento mostrado na Tabela 5.6 para redução do número de bicicletas no domicílio para cada um dos indivíduos contido no banco de dados. Por exemplo, caso a viagem do indivíduo possuísse indicador igual a 0,7505 , a redução seria de 0,343 , ou seja, supõe-se que o número de bicicletas no domicílio diminuiria de 1,433 para 1,09. Analogamente, os casos em que o indicador estivesse compreendido entre 0,4375 e 0,7505, o número de bicicletas no domicílio iria de 1,183 para 1,09 e resultaria no valor utilizado de redução de 0,093 .

Tabela 5.6 - Valor utilizado para redução no número de bicicletas no domicílio

\begin{tabular}{c|c|c}
\hline $\begin{array}{c}\text { Indicador de Infraestrutura } \\
\text { Cicloviária }\end{array}$ & $\begin{array}{c}\mathbf{N}^{\mathbf{0}} \text { de bicicletas } \\
\text { no domicílio }\end{array}$ & $\begin{array}{c}\text { Valor utilizado para redução no } \\
\mathbf{n}^{\mathbf{0}} \text { de bicicletas no domicílio }\end{array}$ \\
\hline$>=0,7505$ & 1,433 & 0,343 \\
\hline$>=0,4375$ e $<0,7505$ & 1,183 & 0,093 \\
\hline$<0,4375$ & 1,09 & - \\
\hline
\end{tabular}

O indicador de infraestrutura cicloviária (IND), obviamente, foi a outra variável modificada significativamente entre as contagens registradas no PCM e o início das entrevistas domiciliares da O/D da RMBS.

$\mathrm{Na}$ época das contagens volumétricas contidas no PCM, não existia ciclovias/ciclofaixas e, por isso, foi adotado o valor de 0 (zero) para o indicador das viagens contidas no banco de dados da RMBS que cruzaram os pontos de contagem. A Figura 5.3 mostra todos os pontos de contagem volumétrica contidos no PCM e verifica-se que há contagem de ciclistas na maioria das ciclovias e/ou ciclofaixas existentes na época da realização da O/D. 


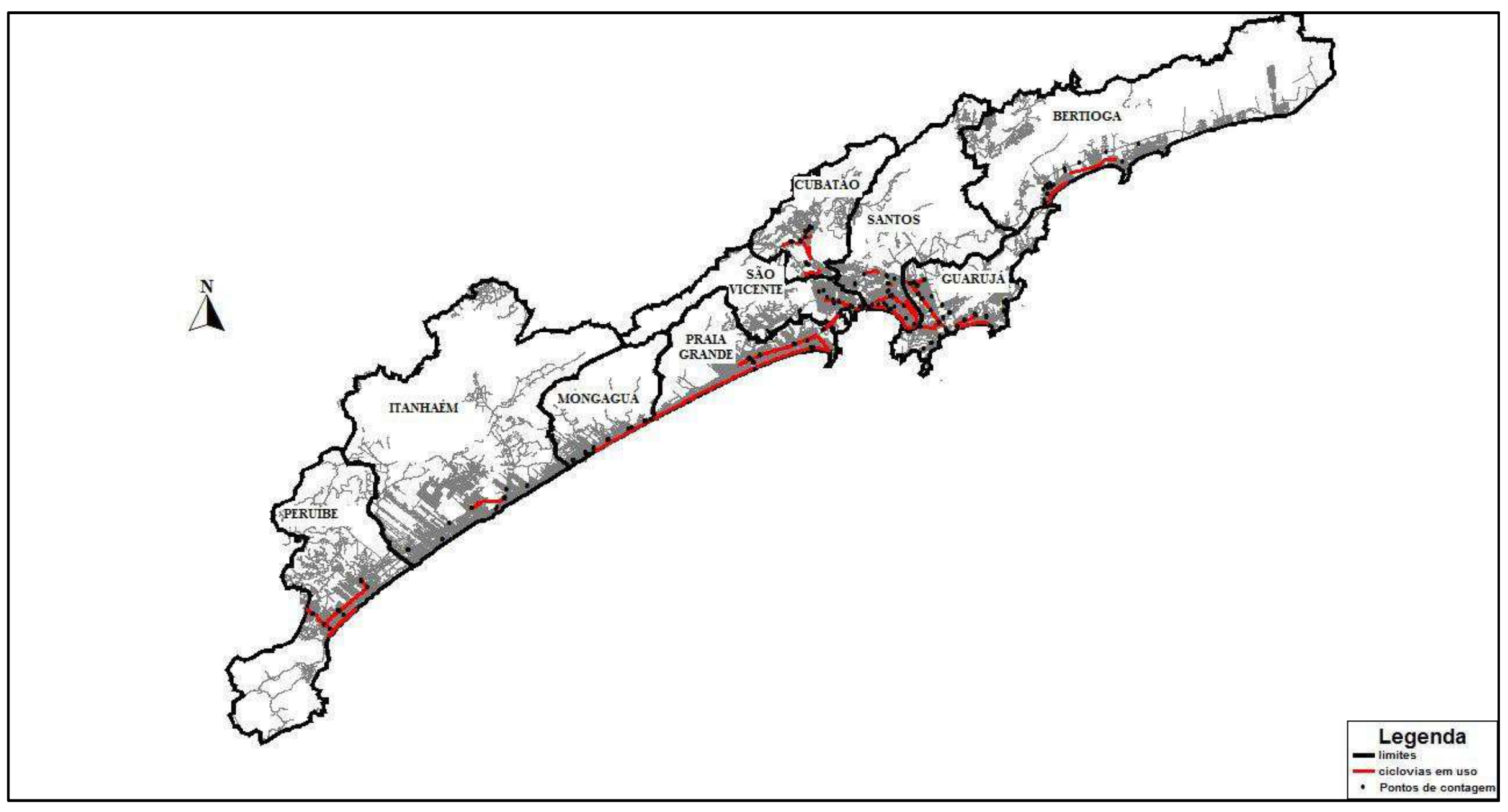

Figura 5.3 - Mapa da RMBS com identificação dos limites dos municípios, infraestrutura cicloviária e pontos de contagem de ciclista 
Desta maneira, após realizar as modificações em variáveis socioeconômicas e no indicador de infraestrutura cicloviária e utilizar o mesmo critério do Cenário 1 para seleção das viagens da $\mathrm{O} / \mathrm{D}$, que passaram pelos pontos de contagem volumétrica de ciclistas, foram estimadas as demandas de ciclistas em cada um destes pontos através do modelo de escolha discreta e, posteriormente, comparadas com os valores registrados no PCM para o ano de 2006.

Salienta-se que para o melhor entendimento do resultado da comparação prevista no Cenário 2, os pontos foram analisados isoladamente com a identificação, através de figuras, dos locais onde foram feitas as contagens volumétricas.

\section{- Ciclovia 1}

O ponto estava localizado na cidade de Santos-SP, nas proximidades da balsa que realiza a viagem entre as cidades de Santos-SP e Guarujá-SP, e onde, reconhecidamente, há grande fluxo de carros, bicicletas e pedestres no dia-a-dia. A Figura 5.4 mostra o ponto de contagem e as zonas de tráfego que formaram pares O/D que utilizaram a rota que passava pelo ponto de contagem dentro do intervalo horário da contagem volumétrica do PCM. As zonas de tráfego que formaram os pares O/D eram das cidades de Cubatão-SP, Guarujá-SP, Praia Grande-SP, Santos-SP e São Vicente-SP.

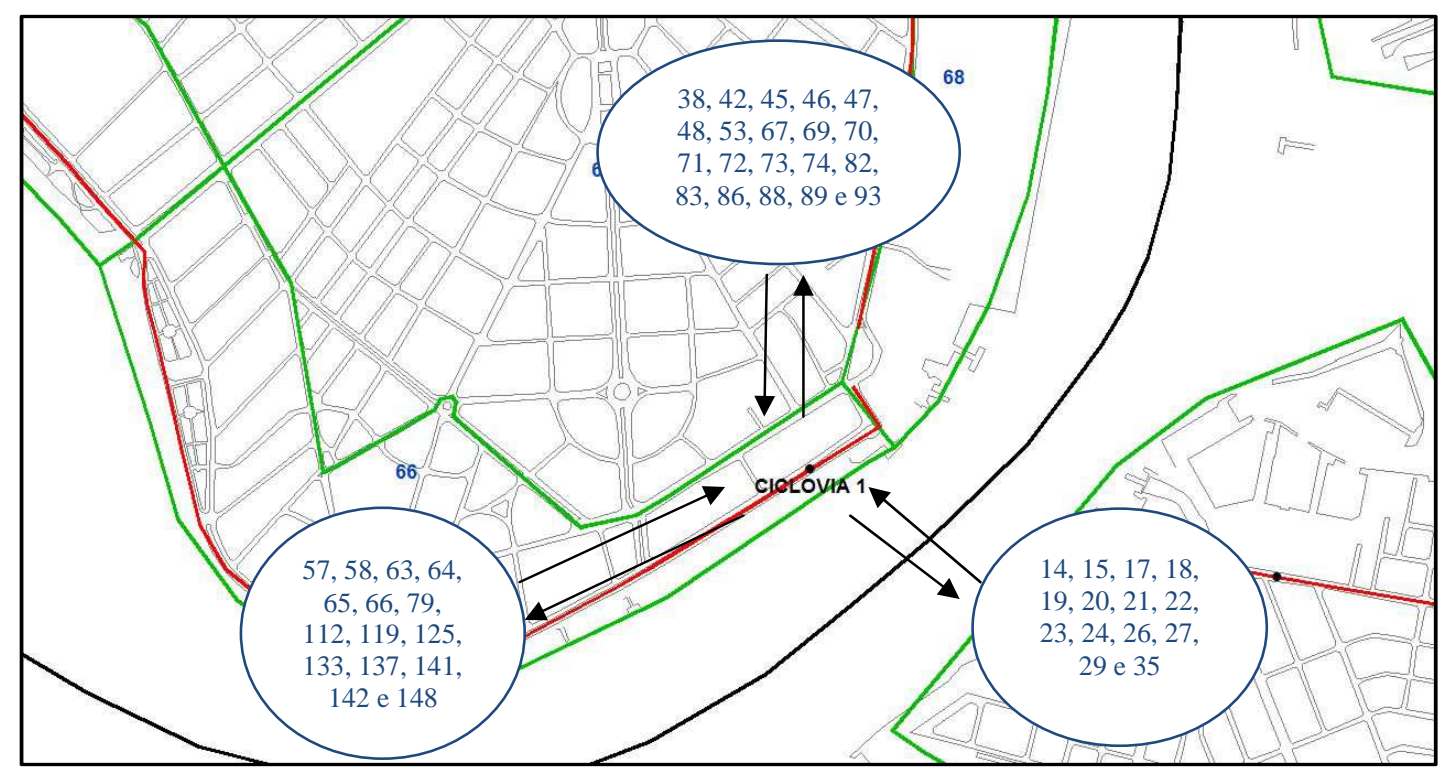

Figura 5.4 - Ponto Ciclovia 1 com identificação das zonas de tráfego que formaram pares $\mathrm{O} / \mathrm{D}$ 
A pesquisa do PCM realizou a contagem volumétrica em 10 minutos, entre os horários de 18:46 e 18:56hs, e determinou um volume de 127 bicicletas nos dois sentidos que, multiplicado por 6 , totalizou 762 bicicletas/hora.

De acordo com a Tabela 5.4, presente no resultado da simulação do Cenário 1, foram selecionadas 73 viagens na Pesquisa O/D, sendo que 20 viagens foram feitas através de bicicleta. A Tabela 5.7 compara o resultado do modelo de escolha discreta para o ano de 2006 e a contagem volumétrica do PCM através da diferença percentual entre as duas previsões.

Tabela 5.7 - Resultado da previsão da demanda cicloviária para o ponto Ciclovia 1

\begin{tabular}{c|c|c|c}
\hline Local & $\begin{array}{c}\text { Modelo logit } \\
\text { multinomial } \\
\text { (bic./h) }\end{array}$ & $\begin{array}{c}\text { PCM } \\
\text { (bic./h) }\end{array}$ & $\begin{array}{c}\text { \% de diferença } \\
\text { (Modelo x PCM) }\end{array}$ \\
\hline Ciclovia 1 & 815 & 762 & 6,96 \\
\hline
\end{tabular}

A diferença da estimação do modelo para a situação na época do PCM foi menor do que $7 \%$. Isto significa que o modelo estimou apenas 53 ciclistas a mais do que o que foi contabilizado, nos dois sentidos, na contagem volumétrica de ciclistas no ponto de contagem.

\section{- Ciclovia 2}

O ponto de contagem Ciclovia 2 estava localizado, na cidade de Santos-SP, na Av. Afonso Pena, próximo da Av. Alm. Cochrane. É um ponto com a presença de vias paralelas adjacentes, como a Rua Liberdade e a Rua Prof. Torres Homem e, além disso, relativamente próxima da Av. dos Portuários, que corre paralelamente, e onde está localizado o Porto da cidade de Santos-SP. A Figura 5.5 mostra o ponto de contagem e as zonas de tráfego que formaram pares $\mathrm{O} / \mathrm{D}$ que passaram dentro do intervalo de uma hora da contagem volumétrica. As zonas de tráfego eram das cidades de Cubatão-SP, Guarujá-SP, Santos-SP e São VicenteSP. 


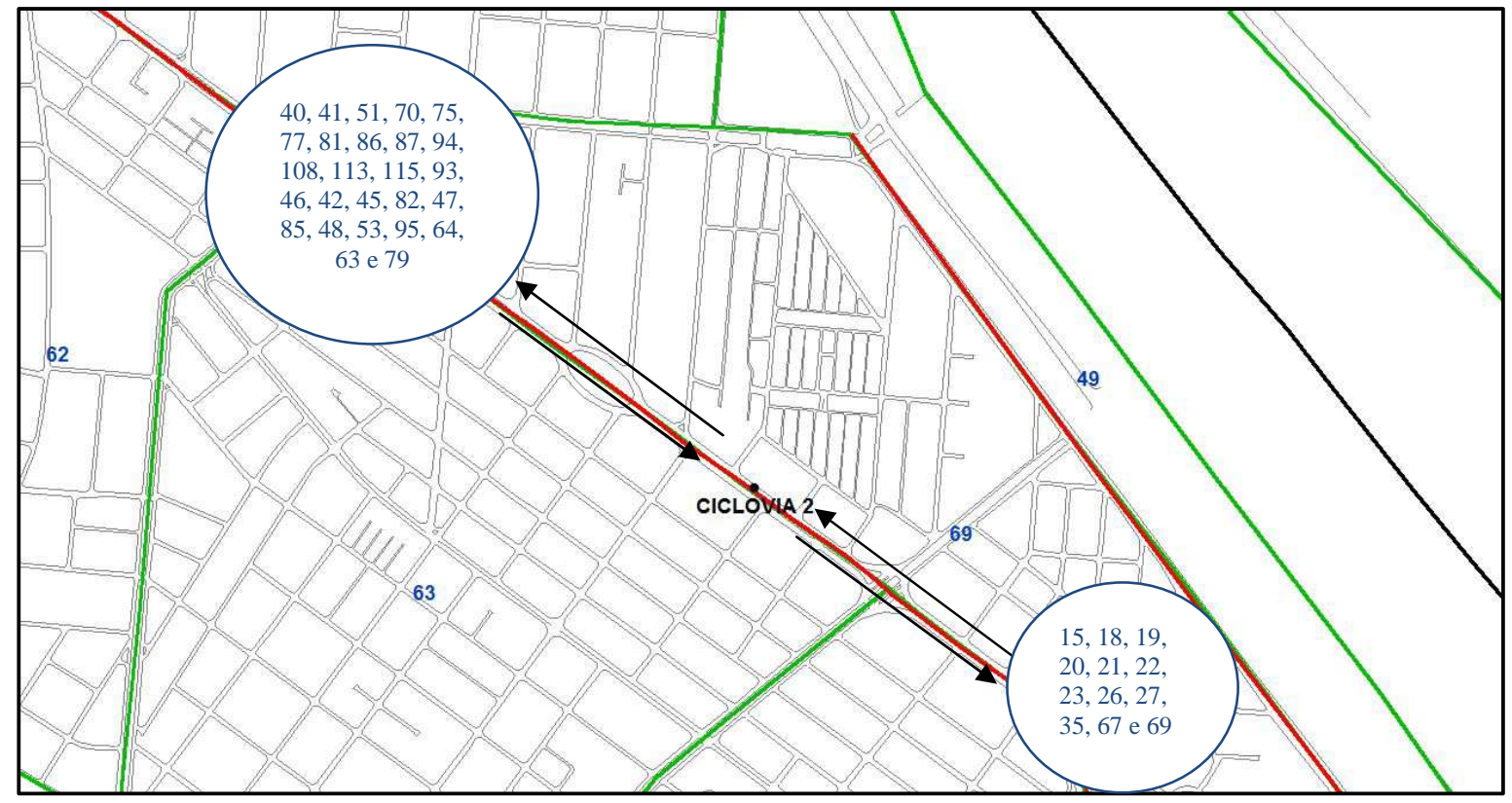

Figura 5.5 - Ponto Ciclovia 2 com identificação das zonas de tráfego que formaram pares $\mathrm{O} / \mathrm{D}$

A contagem volumétrica foi de 10 minutos, entre os horários de 6:52 e 7:02hs, e determinou um volume de 82 bicicletas nos dois sentidos que, multiplicado por 6 , totalizou 492 bicicletas/hora.

A Tabela 5.8 compara os resultados do modelo logit multinomial e da contagem registrada no PCM para o referido ponto. Para este caso, a estimativa do fluxo de ciclistas estimado pelo modelo ficou 70,93\% acima da contagem volumétrica mostrada no PCM.

Tabela 5.8 - Resultado da previsão da demanda cicloviária para o ponto Ciclovia 2

\begin{tabular}{c|c|c|c}
\hline Local & $\begin{array}{c}\text { Modelo logit } \\
\text { multinomial } \\
\text { (bic./h) }\end{array}$ & $\begin{array}{c}\text { PCM } \\
\text { (bic./h) }\end{array}$ & $\begin{array}{c}\text { \% de diferença } \\
\text { (Modelo x PCM) }\end{array}$ \\
\hline Ciclovia 2 & 841 & 492 & 70,93 \\
\hline
\end{tabular}

A justificativa para a diferença considerável entre a previsão do modelo e a contagem de ciclistas pode ser a presença de vias adjacentes à Av. Afonso Pena, onde está localizado o ponto de contagem Ciclovia 2. Como grande parte das viagens é oriunda, ou destinada, das zonas de tráfego 15, 18, 19, 20, 21, 22, 23, 26, 27 e 35, da cidade de Guarujá-SP, conforme visto na Figura 5.5, acredita-se que o ciclista não utilizava necessariamente a Av. Afonso Pena, pois entre a travessia da balsa Santos-SP-Guarujá/SP e as zonas de origem ou destino há 
inúmeros caminhos alternativos, já que não havia infraestrutura de apoio ao ciclista em nenhuma delas.

\section{- Ciclovia 3}

O ponto de contagem Ciclovia 3 está localizado na orla da cidade de Santos-SP, especificamente, na Av. Presidente Wilson, entre o Emissário Submarino, que atualmente é ponto de encontro de famílias, turistas e esportistas da cidade, e a divisa com a cidade de São Vicente-SP. Vale ressaltar que as contagens referentes à Ciclovia 3 até à Ciclovia 5 foram feitas com intuito de serem criadas ciclovias, ou ciclofaixas, ligando a cidade de Santos-SP com a cidade de São Vicente-SP e as demais ao oeste da RMBS (Peruíbe-SP, Mongaguá-SP, Itanhaém-SP e Praia Grande-SP). A Figura 5.6 mostra o ponto de contagem e as zonas de tráfego que formaram pares O/D dentro do intervalo horário da contagem volumétrica.

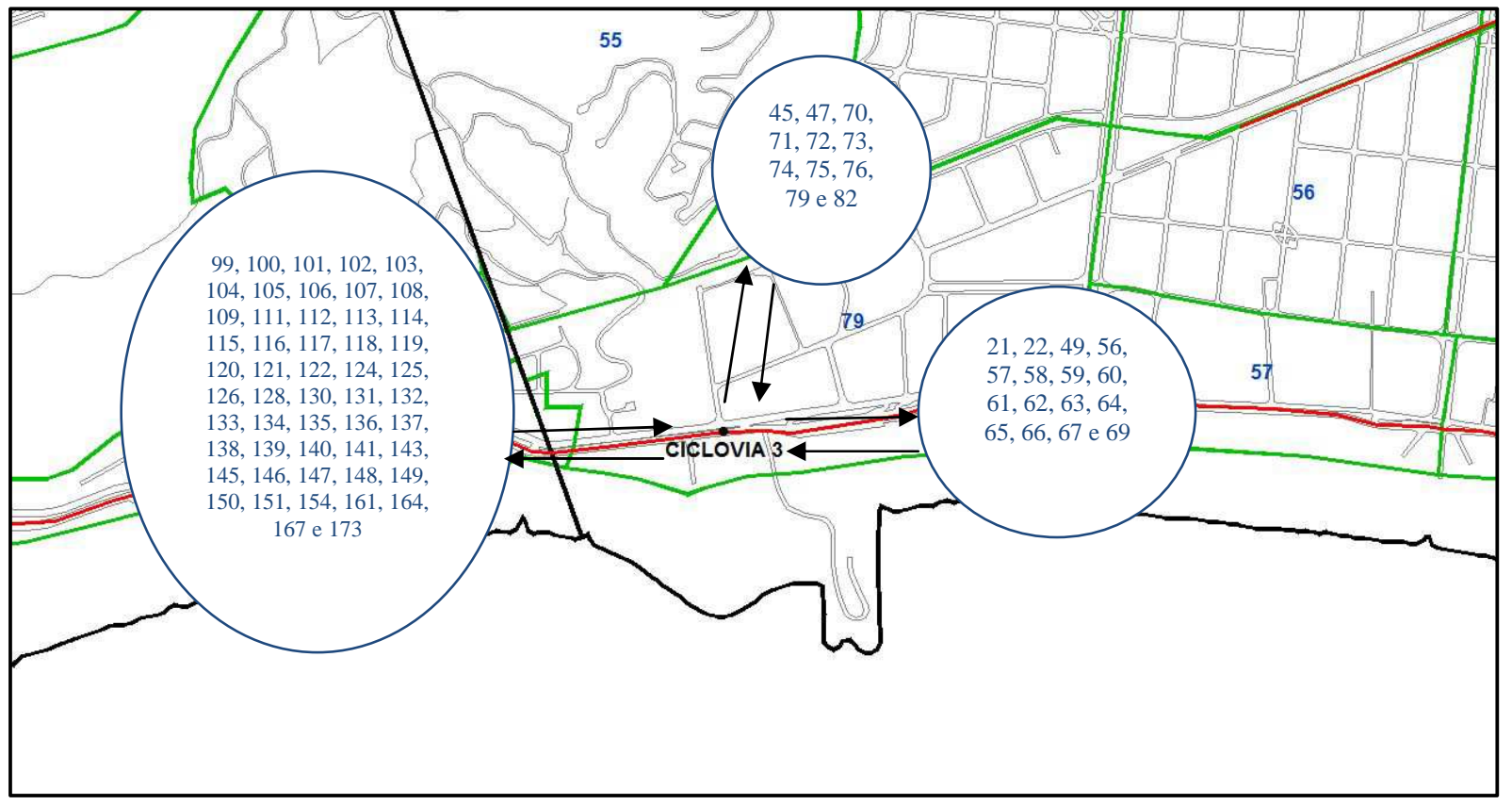

Figura 5.6 - Ponto Ciclovia 3 com identificação das zonas de tráfego que formaram pares $\mathrm{O} / \mathrm{D}$

A contagem volumétrica foi de 10 minutos, entre os horários de 17:45 e 17:55hs, e determinou um volume de 199 bicicletas nos dois sentidos que, multiplicado por 6, totalizou 1194 bicicletas/hora. A Tabela 5.9 compara os resultados do modelo logit multinomial e das contagens do PCM. 
Tabela 5.9 - Resultado da previsão da demanda cicloviária para o ponto Ciclovia 3

\begin{tabular}{c|c|c|c}
\hline Local & $\begin{array}{c}\text { Modelo logit } \\
\text { multinomial } \\
\text { (bic./h) }\end{array}$ & $\begin{array}{c}\text { PCM } \\
\text { (bic./h) }\end{array}$ & $\begin{array}{c}\text { \% de diferença } \\
\text { (Modelo x PCM) }\end{array}$ \\
\hline Ciclovia 3 & 1049 & 1194 & $-13,82$ \\
\hline
\end{tabular}

A zona central de Santos-SP, localizado na zona de tráfego 45, representa a origem, ou destino, de aproximadamente $15 \%$ das viagens selecionadas da $\mathrm{O} / \mathrm{D}$ para a análise deste ponto. Zonas de tráfego da cidade de São Vicente adjacentes à ciclovia, conforme a Figura 4.15, e das cidades ao oeste da RMBS, utilizam a ciclovia para chegar ao centro da cidade de Santos-SP, ou seja, utilizam parte da orla para chegar ao destino final.

Ressalta-se que há barreiras físicas como, por exemplo, os Morros Votaruá e Itararé, que impedem o caminho mais direto para chegar a área central e também portuária de SantosSP. Por este motivo, os moradores de São Vicente-SP têm a opção de seguir pela orla, onde atualmente há ciclovias, ou pela Rodovia Anchieta e vias adjacentes no outro extremo, onde não há infraestrutura de apoio ao ciclista.

Segundo o resultado do procedimento do tempo gasto para chegar à seleção das viagens da O/D, as zonas de tráfego 100, 101, 102, 107 e 109 utilizam o extremo representado pela Rodovia Anchieta, ou vias adjacentes, para chegar à região central da cidade de SantosSP e, por este motivo, não foram selecionadas para estimação da demanda cicloviária pelo modelo de escolha discreta. Pode ser que isto seja um dos motivos da diferença, para menos, de $13,82 \%$ entre a previsão do modelo e a contagem volumétrica do PCM. Porém, não há como confirmar a hipótese pois, na contagem volumétrica do PCM, não havia identificação de origens e destinos e, desta forma, não permitia saber se tais viajantes das zonas de tráfego mais distantes, do local onde seria construída a infraestrutura de apoio aos ciclistas, utilizavam a rota pela orla.

\section{- Ciclovia 4}

A contagem referente ao ponto Ciclovia 4 foi feita na Praia de Itararé, entre a Ilha Porchat e a divisa com o Município de Santos-SP. O intervalo da contagem foi entre 17:20 e 18:20hs, ou seja, durou exatamente 1 hora e determinou um volume de ciclistas de 1013 
bicicletas/hora nos dois sentidos. Juntamente com o ponto Ciclofaixa 6, ainda a ser descrito, foram os únicos pontos que fizeram a contagem durante o intervalo de 1 hora. A Figura 5.7 mostra o ponto de contagem e as zonas de tráfego que formaram pares $\mathrm{O} / \mathrm{D}$ dentro do intervalo de uma hora da contagem volumétrica.

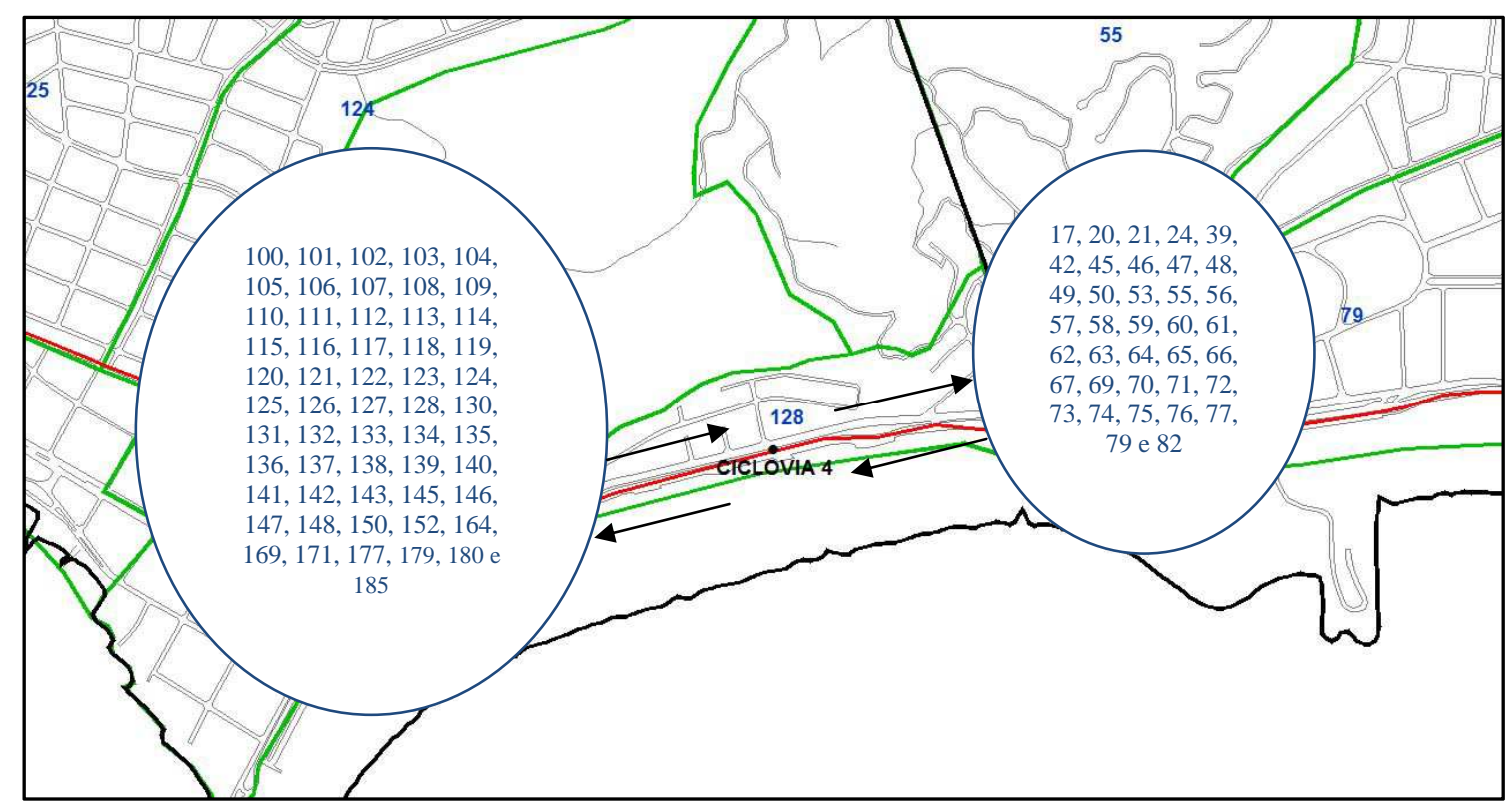

Figura 5.7 - Ponto Ciclovia 4 com identificação das zonas de tráfego que formaram pares $\mathrm{O} / \mathrm{D}$

A comparação entre os resultados da contagem volumétrica e do modelo, no caso da Ciclovia 4, sem a necessidade da compatibilização para unidade de tempo "hora" prevista para os casos das contagens de 10 minutos, supostamente, permitiu que a comparação fosse feita sem o efeito hipotético, de aumento demasiado ou vice-versa, que ocorre ao multiplicar por 6 o número de ciclistas contados em intervalo de 10 minutos. A Tabela 5.10 compara os resultados do modelo logit multinomial e do PCM.

Tabela 5.10 - Resultado da previsão da demanda cicloviária para o ponto Ciclovia 4

\begin{tabular}{c|c|c|c}
\hline Local & $\begin{array}{c}\text { Modelo logit } \\
\text { multinomial } \\
\text { (bic./h) }\end{array}$ & $\begin{array}{c}\text { PCM } \\
\text { (bic./h) }\end{array}$ & $\begin{array}{c}\text { \% de diferença } \\
\text { (Modelo x PCM) }\end{array}$ \\
\hline Ciclovia 4 & 874 & 1013 & $-15,90$ \\
\hline
\end{tabular}

O ponto de contagem, por ter intervalo de horário de contagem parecido e estar próximo do ponto Ciclovia 3, apresentou a similaridade da análise feita anteriormente, ou seja, um dos motivos da diferença de 15,90\%, para menos, na previsão estimada pelo modelo, 
poderia ser causada pela não consideração de viagens originadas, ou destinadas, das zonas 100, 101, 102, 107 e 109, para a região central da cidade de Santos-SP. Vale ressaltar que as zonas de tráfego 100 e 109, segundo o relatório da Pesquisa O/D da RMBS (2007), possuem a $8^{a}$ e $9^{a}$ maior densidade populacional, das 37 zonas de tráfego da cidade de São Vicente-SP, com 145,49 hab/ha e 143,69 hab/ha, respectivamente. Caso tais viagens fossem consideradas, a diferença seria em torno de $10 \%$ para ambos os casos.

\section{- Ciclovia 5}

A Prefeitura Municipal de São Vicente-SP informou que a ciclovia, denominada de "Ciclovia da Linha Amarela", foi implantada na Av. Martins Fontes, também chamada de Linha Amarela, durante o ano de 2006. Esta ciclovia teve 2 pontos de contagem de ciclistas, muito próximos entre si, e diferenciados pelo período do dia em que foi realizada a contagem. O ponto "Ciclovia 5M", localizado entre a Av. Antonio Emmerich e o Canal dos Barreiros mostrado na Figura 5.8, teve pesquisa entre 8:05 e 8:15hs. Já o ponto "Ciclovia 5T", localizado entre as avenidas Monteiro Lobato e Padre Manoel da Nóbrega, presente na Figura 5.9, teve pesquisa entre 18:22 e 18:32hs.

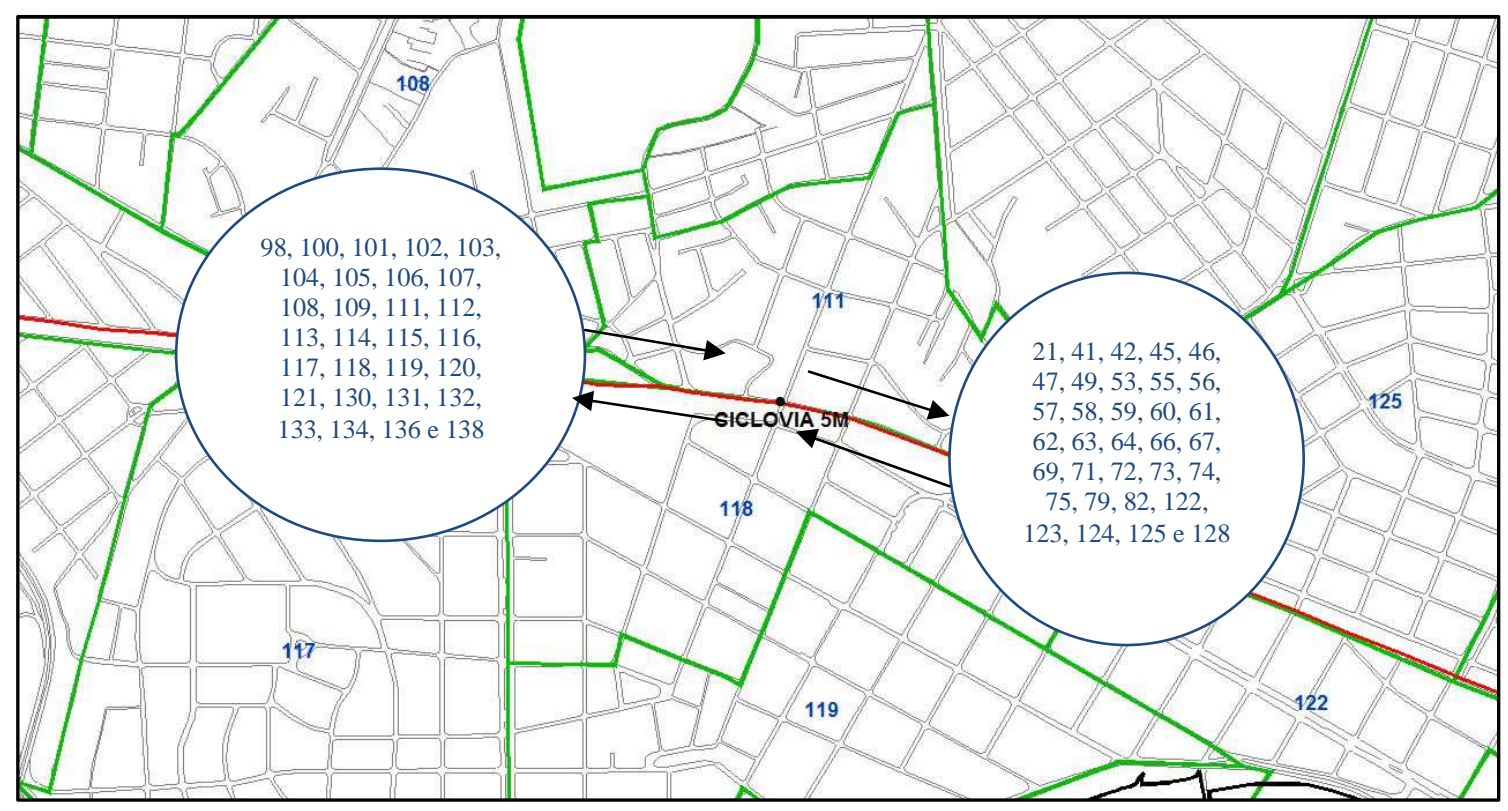

Figura 5.8 - Ponto de contagem Ciclovia 5M realizada entre os horários de 8:05 e 8:15hs 


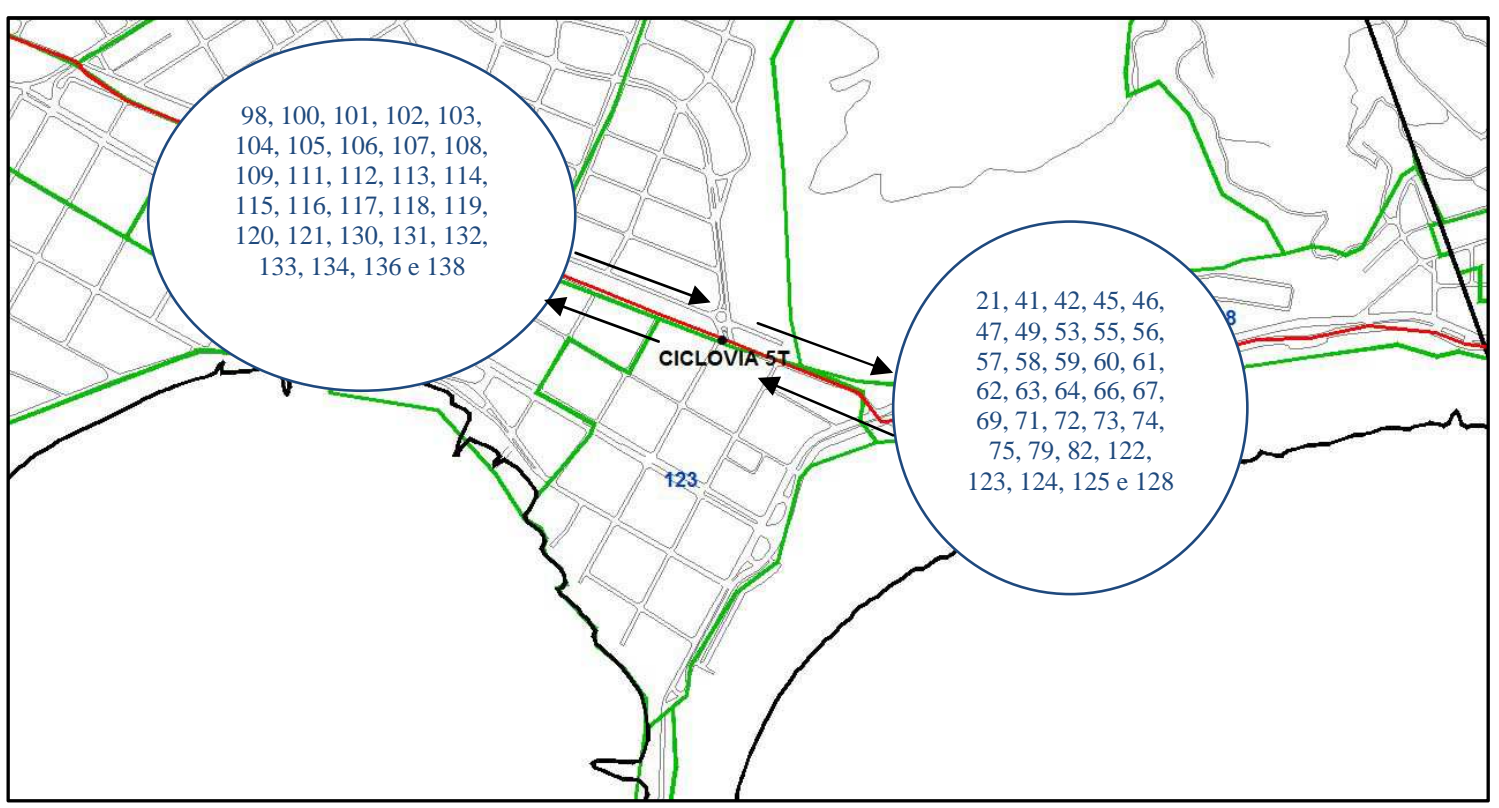

Figura 5.9 - Ponto de contagem Ciclovia 5T realizada entre os horários de 18:22 e 18:32hs

De posse do resultado das contagens volumétricas de ciclistas, pela manhã e pela tarde, é verificado o fluxo maior de ciclistas, no período da manhã, com destino à divisa da cidade de Santos-SP e, à tarde, este fluxo é invertido. A característica, dita anteriormente, de que a cidade de São Vicente-SP é cidade-dormitório, da cidade de Santos-SP, pode ser verificada através do resultado da contagem volumétrica de ciclistas.

No ponto Ciclovia 5M, o sentido divisa de Santos-SP, a contagem foi de 91 ciclistas no período de 10 minutos. Já o sentido Canal dos Barreiros, para adentrar na cidade de São Vicente-SP, apresentou apenas 3 ciclistas. No ponto Ciclovia 5T, o sentido Av. Monteiro Lobato, para adentrar na cidade de São Vicente-SP, apresentou 55 ciclistas contra apenas 8 ciclistas, no mesmo período de 10 minutos, no sentido da Av. Padre Manoel da Nóbrega. A Tabela 5.11 mostra o resultado da comparação das previsões através do modelo e das contagens volumétricas do PCM, em uma hora.

Tabela 5.11 - Resultado da previsão da demanda cicloviária para os pontos Ciclovia 5M e 5T

\begin{tabular}{c|c|c|c}
\hline Local & $\begin{array}{c}\text { Modelo logit } \\
\text { multinomial } \\
\text { (bic./h) }\end{array}$ & $\begin{array}{c}\text { PCM } \\
\text { (bic./h) }\end{array}$ & $\begin{array}{c}\text { \% de diferença } \\
\text { (Modelo x PCM) }\end{array}$ \\
\hline Ciclovia 5M & 667 & 564 & 18,26 \\
\hline Ciclovia 5T & 703 & 378 & 85,98 \\
\hline
\end{tabular}


Para os dois casos há a presença de vias adjacentes à Av. Martins Fontes, onde estão localizados os pontos de contagem, e como no caso da Ciclovia 2, acredita-se que o ciclista utilizava qualquer via paralela à via que recebeu a infraestrutura de apoio ao ciclista. No entanto, a diferença mais acentuada foi em relação ao ponto Ciclovia 5T, que apresentou diferença de 85,98\% na estimação através do modelo logit multinomial. Além disso, os 10 minutos escolhidos para a contagem e que serviram para representar a unidade de tempo "hora", podem não estar representando adequadamente a hora-pico.

\section{- Ciclofaixa 6}

A contagem feita na Av. Puglisi, entre o trecho compreendido entre a Rua Mário Ribeiro e o Viaduto Floriberto Mariano, assim como as contagens dos pontos Ciclofaixa 9 e Ciclovia 10, serviram para justificar a construção da ciclofaixa que foi construída, na cidade de Guarujá-SP, em quase toda extensão perpendicular compreendida entre a Praia de Pitangueiras e o distrito conhecido como Vicente de Carvalho. A Figura 5.10 mostra o ponto de contagem e as respectivas zonas de tráfego que formaram os pares O/D.

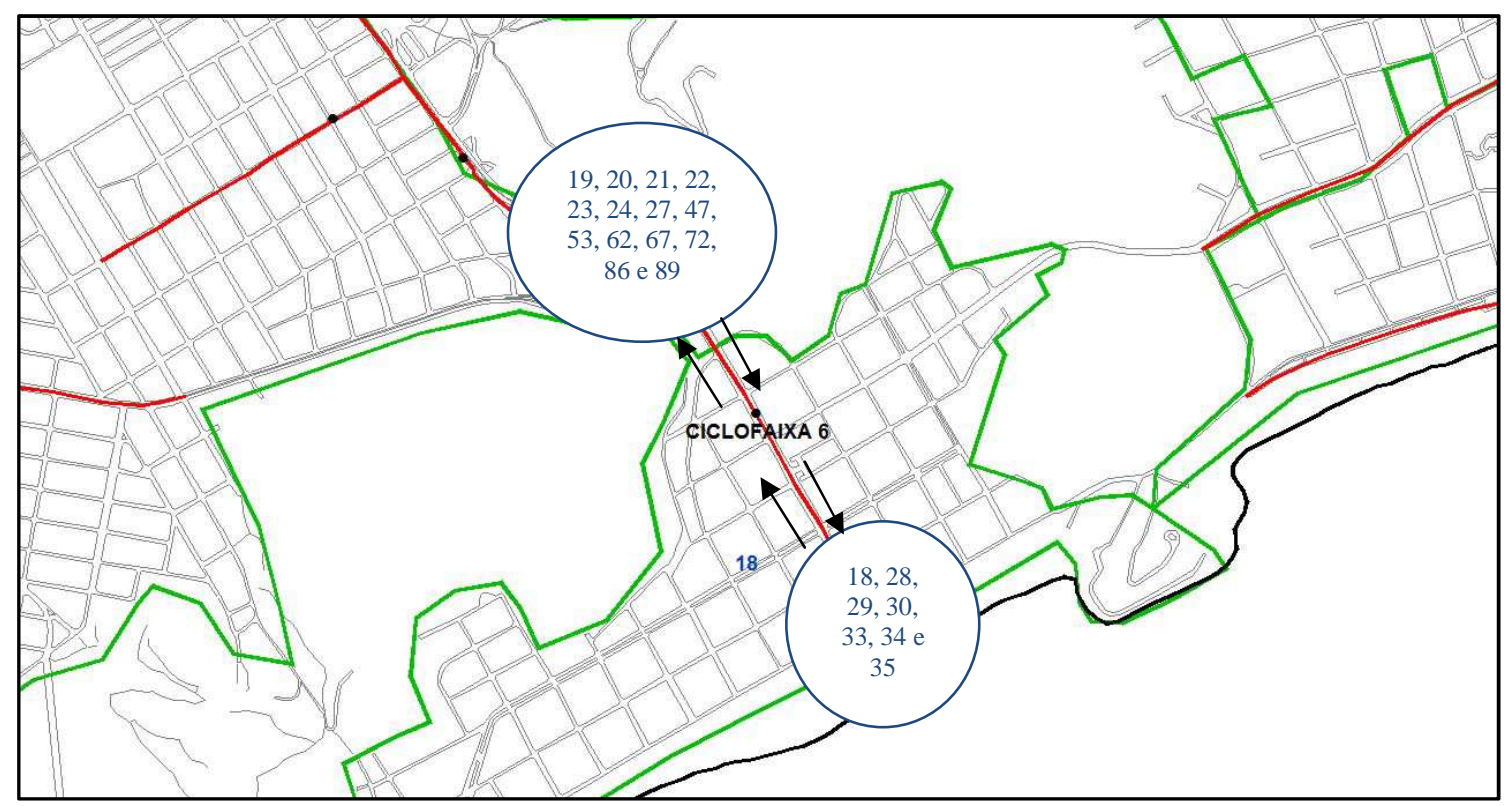

Figura 5.10 - Ponto de contagem Ciclofaixa 6 com identificação das zonas de tráfego que formaram Pares O/D

Como no caso da Ciclovia 4, a contagem neste ponto foi realizada no período de 1 hora. O horário entre 17:30 e 18:30hs contabilizou 403 ciclistas nos dois sentidos. A Tabela 5.12 mostra o resultado da comparação entre o volume de ciclistas estimado pelo modelo e a contagem volumétrica do PCM. 
Tabela 5.12 - Resultado da previsão da demanda cicloviária para o ponto Ciclofaixa 6

\begin{tabular}{c|c|c|c}
\hline Local & $\begin{array}{c}\text { Modelo logit } \\
\text { multinomial } \\
\text { (bic./h) }\end{array}$ & $\begin{array}{c}\text { PCM } \\
\text { (bic./h) }\end{array}$ & $\begin{array}{c}\text { \% de diferença } \\
\text { (Modelo x PCM) }\end{array}$ \\
\hline Ciclofaixa 6 & 395 & 403 & $-2,03$ \\
\hline
\end{tabular}

De acordo com a Tabela 5.12, o modelou praticamente estimou o mesmo número de ciclistas no trecho, registrado no PCM, e isto pode ser devido ao fato de que no ponto não havia:

(a) Interferências causadas por contagens feitas em apenas 10 minutos, que foram expandidas para hora;

(b) Vias adjacentes que "competem" pela preferência do ciclista ao escolher o caminho entre origem e destino;

(c) Pares O/D que podem ou não utilizar a rota.

Vale ressaltar que o ponto está localizado na única via que liga a Praia de Pitangueiras, onde está localizado o prédio da Prefeitura Municipal, ao distrito de Vicente de Carvalho, que compreende as zonas de tráfego 19, 20 e 21.

\section{- Ciclofaixa 7}

O ponto de contagem da Ciclofaixa 7 está localizado na Av. Adhemar de Barros na cidade de Guarujá-SP, nas proximidades da saída da travessia de balsa entre Santos-SP e Guarujá-SP, e apresentou contagem volumétrica, entre 6:30 e 6:40hs, de 158 ciclistas que, multiplicados por 6, totalizaram 948 ciclistas por hora. A Figura 5.11 detalha a localização do ponto de contagem e as zonas de tráfego que formaram os pares O/D. 


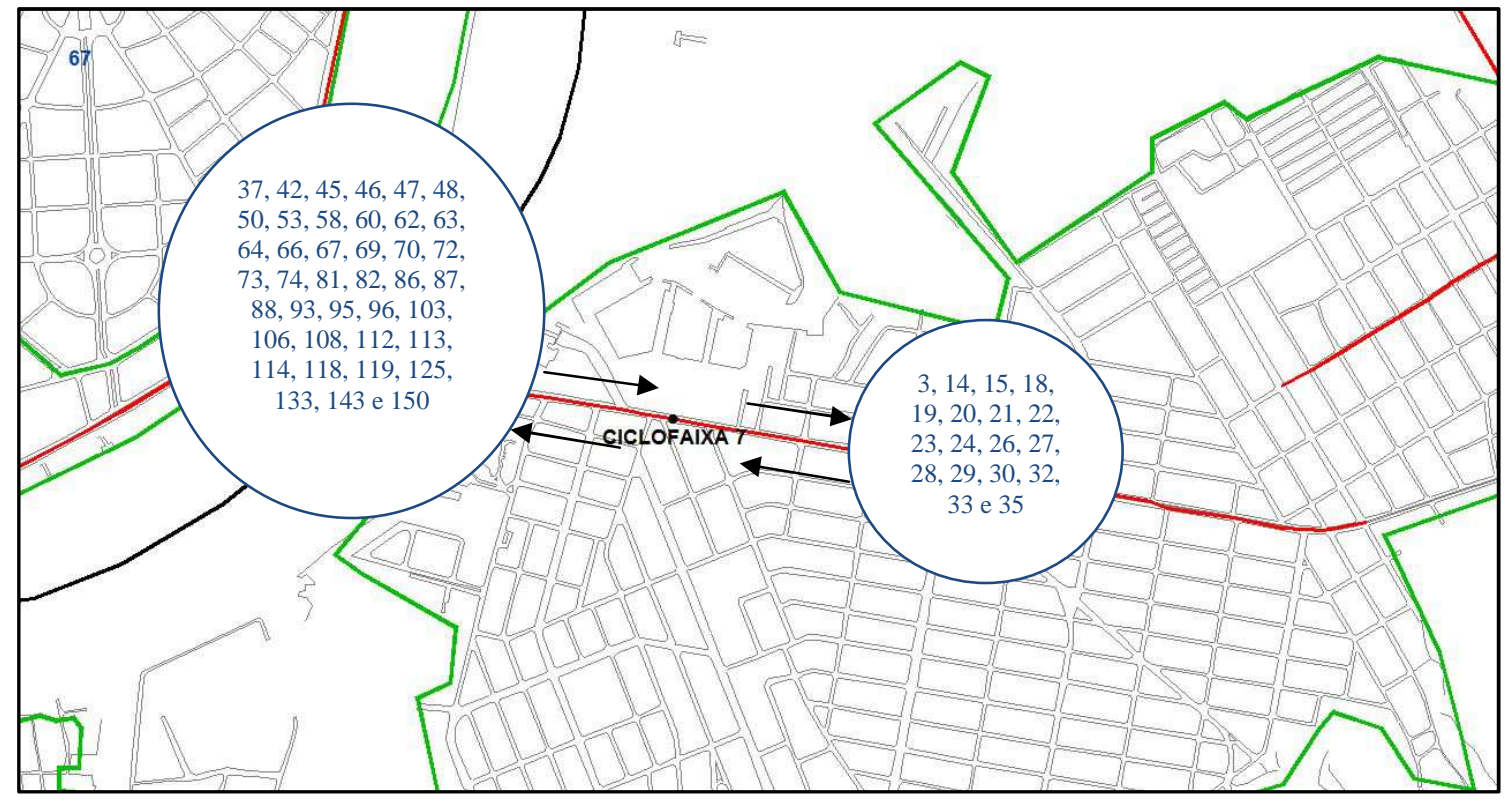

Figura 5.11 - Ponto de contagem Ciclofaixa 7 com identificação das zonas de tráfego que formaram Pares O/D

De acordo com a Tabela 5.13, para este caso, a previsão do fluxo de ciclistas pelo modelo ficou apenas $1,58 \%$ acima da contagem volumétrica registrada no PCM.

Tabela 5.13 - Resultado da previsão da demanda cicloviária para o ponto Ciclofaixa 7

\begin{tabular}{c|c|c|c}
\hline Local & $\begin{array}{c}\text { Modelo logit } \\
\text { multinomial } \\
\text { (bic./h) }\end{array}$ & $\begin{array}{c}\text { PCM } \\
\text { (bic./h) }\end{array}$ & $\begin{array}{c}\text { \% de diferença } \\
\text { (Modelo x PCM) }\end{array}$ \\
\hline Ciclofaixa 7 & 963 & 948 & 1,58 \\
\hline
\end{tabular}

O ponto de contagem estava localizado na via que leva até a balsa que realiza a travessia e, portanto, tinha a preferência das pessoas pois não havia a necessidade de desviar o caminho para vias adjacentes. Além disso, devido à barreira física representada pelo canal do Porto de Santos, os pares O/D só poderiam ser formados por zonas de tráfego, originadas e destinadas, da cidade de Guarujá-SP ou Bertioga-SP, para as demais cidades da RMBS.

Salienta-se que há casos de viagens a pé, principalmente, da zona de tráfego 45 (centro de Santos-SP) para as zonas do Distrito de Vicente de Carvalho (19, 20 e 21) que utilizam catraias, tipo de embarcação para poucos passageiros que existem nas proximidades do centro de Santos-SP, para atravessar o canal do porto de Santos até o distrito de Vicente Carvalho e 
reduz substancialmente o tempo de viagem. Tais viagens não foram consideradas pois não cruzaram o ponto de contagem.

\section{- Ciclofaixa 8}

Localizado na Alameda das Tulipas próximo da Av. Santos Dumont, na cidade de Guarujá-SP, o ponto teve contagem volumétrica de ciclistas entre às 6:30 e 6:40hs que, expandido, foi de 582 ciclistas/hora nos dois sentidos. A via foi escolhida para receber a ciclofaixa que serviria para que as pessoas que utilizam a travessia de balsa pudessem chegar mais rapidamente, e de forma segura, até o Distrito de Vicente de Carvalho. É possível notar, através da Figura 5.12, a presença de vias paralelas à Alameda das Tulipas.

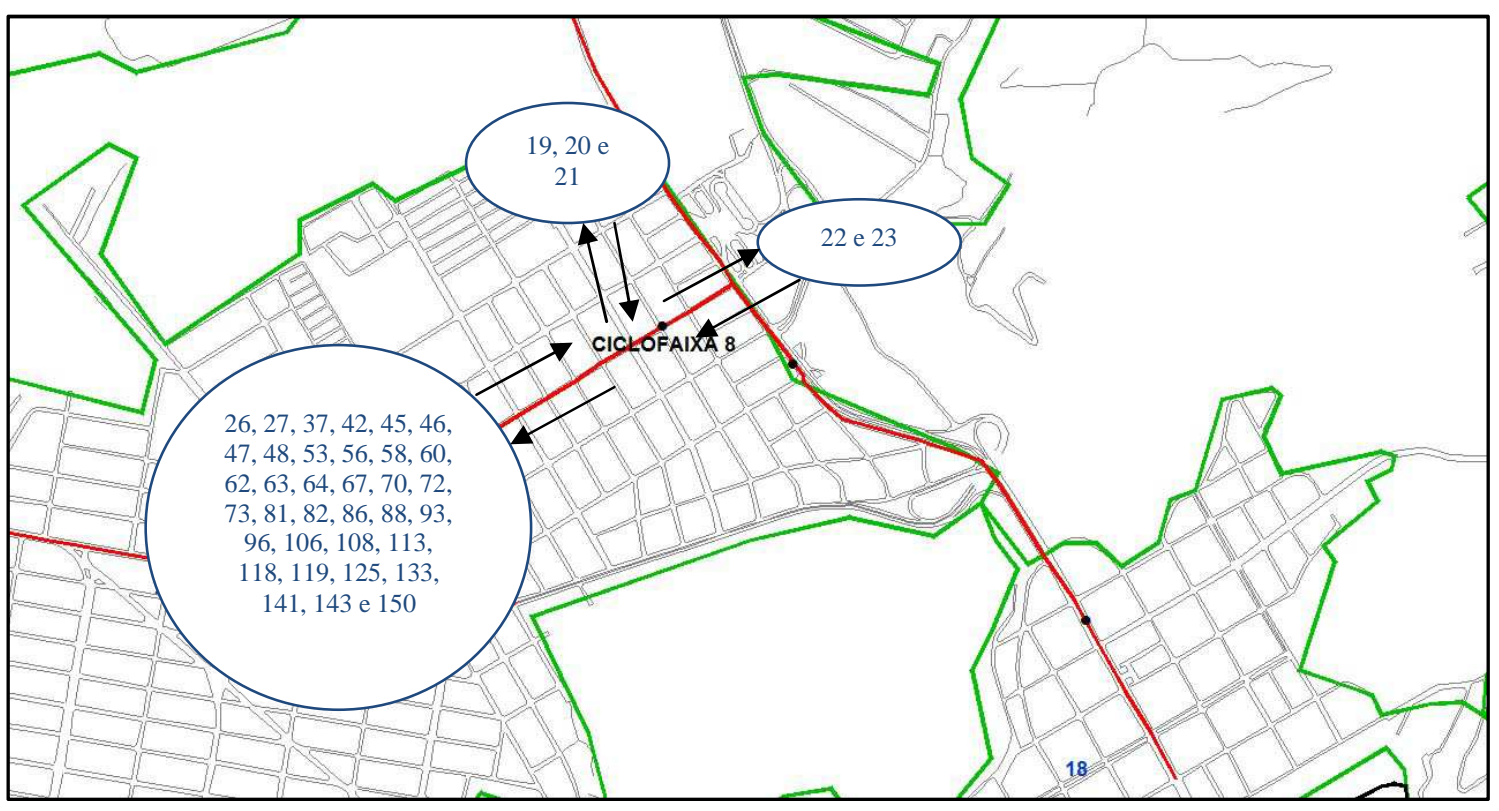

Figura 5.12 - Ponto de contagem, Ciclofaixa 8 com identificação das zonas de tráfego que formaram Pares O/D

A Tabela 5.14 compara a previsão de demanda cicloviária através do modelo e a contagem volumétrica do PCM. Novamente, as vias paralelas à via que recebeu a infraestrutura de apoio ao ciclista, na época da contagem volumétrica, provavelmente "competiam" pela preferência de rota pelos viajantes urbanos e, por este motivo, houve a diferença percentual aproximadamente igual a $60 \%$ entre as duas estimativas. 
Tabela 5.14 - Resultado da previsão da demanda cicloviária para o ponto Ciclofaixa 8

\begin{tabular}{c|c|c|c}
\hline Local & $\begin{array}{c}\text { Modelo logit } \\
\text { multinomial } \\
\text { (bic./h) }\end{array}$ & $\begin{array}{c}\text { PCM } \\
\text { (bic./h) }\end{array}$ & $\begin{array}{c}\text { \% de diferença } \\
\text { (Modelo x PCM) }\end{array}$ \\
\hline Ciclofaixa 8 & 928 & 582 & 59,45 \\
\hline
\end{tabular}

\section{- Ciclofaixa 9}

Este ponto de contagem está localizado na Av. Santos Dumont, continuação da Av. Puglisi onde ficou localizado o ponto de contagem referente à Ciclofaixa 6, entre a Alameda das Tulipas e o Viaduto Floriberto Mariano. A via representa o único acesso ao Distrito de Vicente de Carvalho e, como já dito, teve 3 pontos de contagem volumétrica de ciclistas representado pelas Ciclofaixas 6,9 e 10. A Figura 5.13 ilustra o ponto de contagem em questão e as zonas de tráfego que formaram os pares O/D.

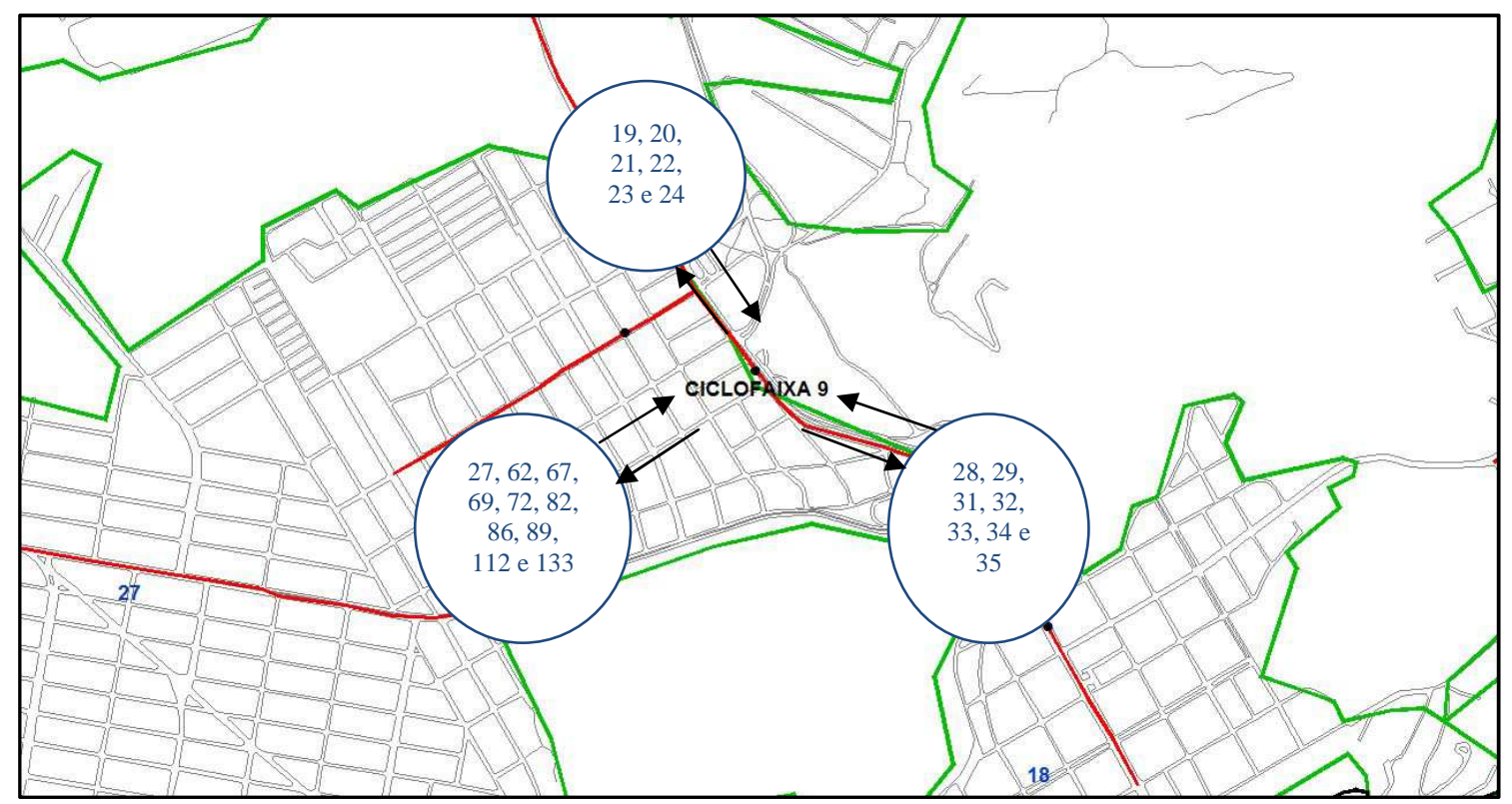

Figura 5.13 - Ponto de contagem, Ciclofaixa 9 com identificação das zonas de tráfego que formaram Pares O/D

A contagem foi realizada entre 6:30 e 6:40hs que, após expandida, apresentou o volume de 360 ciclistas/hora. A Tabela 5.15, assim como as demais anteriores, compara as previsões previstas na simulação do Cenário 2 . 
Tabela 5.15 - Resultado da previsão da demanda cicloviária para o ponto Ciclofaixa 9

\begin{tabular}{c|c|c|c}
\hline Local & $\begin{array}{c}\text { Modelo logit } \\
\text { multinomial } \\
\text { (bic./h) }\end{array}$ & $\begin{array}{c}\text { PCM } \\
\text { (bic./h) }\end{array}$ & $\begin{array}{c}\text { \% de diferença } \\
\text { (Modelo x PCM) }\end{array}$ \\
\hline Ciclofaixa 9 & 378 & 360 & 5,00 \\
\hline
\end{tabular}

É possível notar a pouca diferença, para mais, entre a previsão do modelo e o dado de bicicletas/hora registrado no PCM. Neste caso, foram previstos apenas 18 ciclistas a mais, no intervalo de 1 hora, através do modelo de escolha discreta.

\section{- Ciclovia 10}

O ponto Ciclovia 10 está localizado na Av. Santos Dumont, nas proximidades da esquina com a Av. Vicente de Carvalho, e apresentou 852 ciclistas/hora nos 2 sentidos. Como já dito, foi executada a construção de um corredor cicloviário, ligando o centro de Guarujá-SP e o ponto de travessia da balsa Santos-SP/Guarujá-SP até o distrito de Vicente de Carvalho e, para tanto, foram realizadas contagens volumétricas ao longo do trecho antes da realização da construção. A Figura 5.14 ilustra o ponto de contagem em questão e as zonas de tráfego que formaram os pares $\mathrm{O} / \mathrm{D}$.

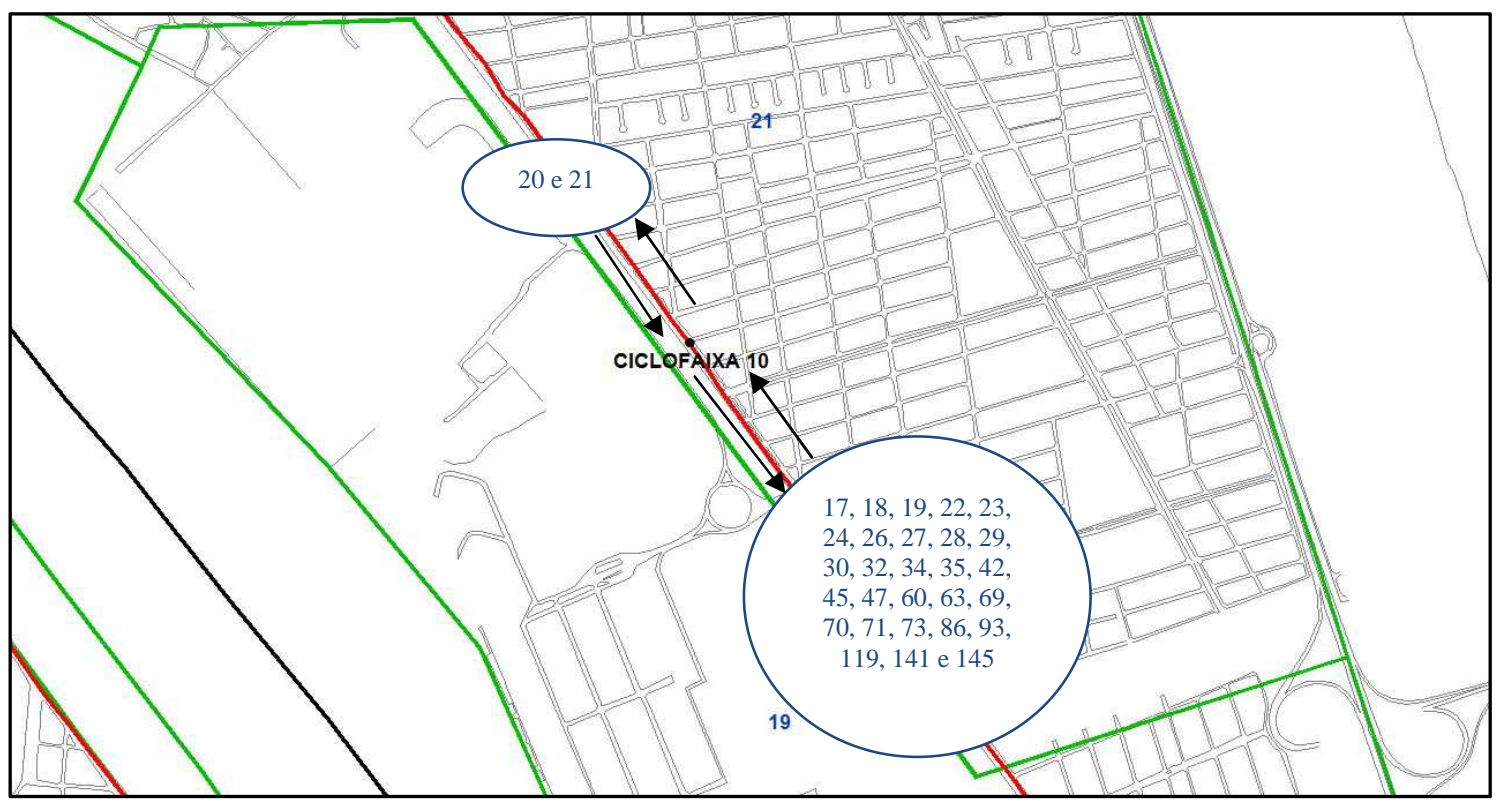

Figura 5.14 - Ponto de contagem Ciclovia 10 com identificação das zonas de tráfego que formaram Pares O/D 
A previsão da demanda cicloviária através do modelo logit multinomial, para o ano de 2006, está mostrada na Tabela 5.16. Comparado com o dado da contagem volumétrica de ciclistas registrado no PCM, verifica-se que o modelo obteve resultado muito próximo.

Tabela 5.16 - Resultado da previsão da demanda cicloviária para o ponto Ciclovia 10

\begin{tabular}{c|c|c|c}
\hline Local & $\begin{array}{c}\text { Modelo logit } \\
\text { multinomial } \\
\text { (bic./h) }\end{array}$ & $\begin{array}{c}\text { PCM } \\
\text { (bic./h) }\end{array}$ & $\begin{array}{c}\text { \% de diferença } \\
\text { (Modelo x PCM) }\end{array}$ \\
\hline Ciclovia 10 & 788 & 852 & $-8,12$ \\
\hline
\end{tabular}

Devido à localização da via onde estava o ponto de contagem, que possui a preferência do ciclista para realizar a rota de viagem, e as respectivas modificações nas variáveis socioeconômicas e do indicador de infraestrutura cicloviária, o modelo previu adequadamente a demanda cicloviária no ponto Ciclovia 10, assim como nos casos dos pontos Ciclovia 1, 3, 4, 5M e Ciclofaixa 6, 7 e 9 mostrados anteriormente. 


\section{CAPÍTULO 6}

\section{ANÁLISE E DISCUSSÃO DE}

RESULTADOS

\subsection{Considerações Iniciais}

No capítulo anterior, o experimento para estimação do modelo de escolha discreta, com os dados reduzidos da O/D da RMBS, e o uso deste modelo para estimativa da demanda cicloviária e comparação com dados de fluxo de ciclistas, antes e depois da implantação de infraestrutura cicloviária, foram descritos e divididos em seções de especificação e resultado da estimação do modelo e construções dos Cenários 1 (ano 2007) e 2 (ano 2006).

Com intuito de refutar ou não as hipóteses de que é possível identificar, e quantificar, fatores que influem no uso de bicicletas e de que estes fatores podem ser usados para avaliar e planejar a infraestrutura de apoio ao ciclista e, em sequência ao método utilizado no trabalho ora proposto, nesta seção, são mostradas as análises obtidas através dos resultados do experimento proposto.

As análises foram divididas em duas seções, a saber:

- Análise da especificação do modelo de escolha discreta obtido com os dados da RMBS; 
- Análise dos Cenários 1 e 2.

Cada uma destas análises foi acompanhada de discussões, de forma a atingir os objetivos do trabalho e, ao final, resumidamente, houve uma discussão sobre as principais observações sobre o uso da bicicleta na RMBS.

Apesar de ser assunto recente na área de Planejamento e Operação de Transportes, sempre que possível, os resultados foram comparados com trabalhos encontrados na literatura pesquisada sobre o uso da bicicleta em viagens urbanas.

\subsection{Análise da Especificação do Modelo de Escolha Discreta obtido com os Dados da RMBS}

As funções utilidade geradas com o uso do software BIOGEME 1.8 (BERLAIRE, 2009), através do banco de dados reduzido da O/D da RMBS, para as alternativas de modo de transporte privado, público, bicicleta e à pé, foram mostradas no capítulo anterior. As equações de (15) até (18) apresentam, resumidamente, o resultado dos parâmetros estimados e da estatística $t$ entre parênteses, para cada alternativa, para as variáveis independentes e as constantes específicas. Para cada modo, há uma discussão sobre o resultado encontrado para a especificação da função utilidade.

A partir das constantes específicas geradas, para cada alternativa de modo de transporte, e assumindo o valor igual a 0 para todos os parâmetros especificados, foi calculada a probabilidade da escolha das 04 alternativas de modo de viagem com intuito de analisar o efeito das variáveis independentes no processo de decisão de escolha do modo. Para esta análise, a alternativa dominante foi o modo à pé, com 57, que diferiu da Tabela 4.5, que apresentou valor aproximado igual à 17 para o modo à pé.

Desta forma, como os valores das ASC não reproduzem as proporções reveladas no banco de dados e, portanto, não influenciam significativamente nas funções utilidade, pode-se afirmar que as especificações dos parâmetros das funções de utilidade capturam os efeitos das diferenças entre os modos de transportes e que não há elementos para refutar o modelo estimado para simular o processo individual de decisão de escolha do modo para a RMBS. 


\subsubsection{Análise da especificação da função utilidade para o modo Privado}

Para o modo privado, o MNL gerou a seguinte função utilidade:

$U_{\text {privado }}=0,0-1,14_{(-12,66)} \times$ Tprivado-0,164 $(-6,80) \times$ Cprivado $+1,74_{(30,68)} \times N$ carl $+3,19_{(27,59)}$

$x$ Ncar $2+0,621_{(11,18)} x$ SF 1

Em que:

- Tprivado é a variável contínua referente ao tempo de viagem gasto pelo modo privado;

- Cprivado é a variável contínua referente ao custo de viagem através do modo privado;

- Ncarl é a variável dummy referente à presença ou não de 1 automóvel no domicílio;

- Ncar2 é a variável dummy referente à presença ou não de mais de 1 automóvel no domicílio;

- SF1 é a variável dummy referente à pertencer ou não à situação familiar "Chefe".

A constante específica para o modo privado foi a escolhida para ser fixada e, portanto, assumiu o valor zero. Os valores dos sinais dos coeficientes encontrados, positivos ou negativos, estão condizentes com o esperado, já que variáveis como, por exemplo, tempo e custo de viagem são inibidoras de viagens quando crescem.

A estimativa do valor do tempo de viagem, definida como a derivada da função utilidade em relação ao tempo dividido pela derivada da função utilidade em relação ao custo, para o caso do modo privado da O/D da RMBS, onde a variável custo de viagem do modo privado estava em reais $(\mathrm{R} \$)$ e o tempo de viagem em hora (h), foi de $\mathrm{R} \$ 6,95$ por hora. Provavelmente este seria o valor que o usuário do modo privado estaria disposto a pagar a mais para abreviar a viagem em 1 hora.

Portugal e Goldner (2003), após a aplicação do modelo logit multinomial para estimar o valor do tempo de usuários de dois supermercados, localizados em áreas distintas (Centro e Beira-Mar da cidade de Florianópolis, respectivamente), através dos modos privado e público, obtiveram o valor de $\mathrm{R} \$ 0,02$ por minuto, para usuários do supermercado do centro da cidade, e $\mathrm{R} \$ 0,03$ por minuto, para usuários do supermercado à beira-mar. Caso a análise do valor do tempo fosse separada, provavelmente, os valores do tempo de viagem seriam diferentes, tanto para o modo privado como para o modo público. 
A codificação do tipo dummy, das variáveis Ncarl e Ncar2, tiveram como referência a categoria referente a zero automóvel no domicílio. Nesta codificação, um atributo com L categorias é transformado em L-1 variáveis dummy, em que cada dummy recebe valor igual a 1 quando a categoria é presente e 0 quando for ausente. No caso das variáveis criadas para a posse de automóveis no domicílio, a categoria excluída, para evitar a perfeita colinearidade, foi a de 0 automóveis no domicílio.

Assim, além do sinal positivo, a magnitude dos parâmetros estimados para o número de automóveis no domicílio está condizente com o esperado pois, em relação à categoria zero automóveis no domicílio, é de se esperar que o peso do parâmetro de mais de 1 automóvel seja maior do que o peso do parâmetro para apenas 1 automóvel no domicílio.

Segundo Silva (2011), a cessão do uso do automóvel para um membro em particular no domicílio pode ser influenciada, entre outros motivos, pela prioridade da atividade no domicílio como, por exemplo, a necessidade de o chefe da família utilizar o automóvel para realizar a viagem com motivo trabalho para a subsistência da família. Na função utilidade mostrada na Equação (15), o valor positivo e o respectivo peso mostraram que o chefe da família, no caso da RMBS, deteve a prioridade no uso do automóvel.

\subsubsection{Análise da especificação da função utilidade para o modo Público}

A função utilidade gerada foi:

$U_{\text {público }}=1,72_{(14,70)}-0,65_{(-14,43)} x$ Tpúblico $-0,178_{(-4,08)} \times$ Cpúblico $-0,421_{(-7,37)} x$ VE2 $0,899_{(-5,31)} x \mathrm{VE3}-0,579_{(-4,84)} \times \mathrm{RD} 1-0,292_{(-4,01)} \times \mathrm{RD} 2$

Em que:

- Tpúblico é a variável contínua referente ao tempo de viagem gasto pelo modo público;

- Cpúblico é a variável contínua referente ao custo de viagem através do modo público;

- VE2 é a variável dummy referente a pertencer ou não à categoria assalariado sem carteira, autônomo ou profissional liberal;

- VE3 é a variável dummy referente a pertencer ou não à categoria empregador, dono de negócio familiar, trabalhador familiar ou voluntário;

- $\quad$ RDI é a variável dummy referente a pertencer ou não à categoria de renda domiciliar de 0 até $\mathrm{R} \$ 800,00$; 
- $\quad R D 2$ é a variável dummy referente a pertencer ou não à categoria de renda domiciliar de de $\mathrm{R} \$ 800,00$ até $\mathrm{R} \$ 1.600,00$;

Conforme o esperado, as variáveis tempo de viagem e custo de viagem apresentaram sinal negativo. Para o modo Público, na RMBS, o valor do tempo é igual a $\mathrm{R} \$ 3,65$ por hora, ou, $\mathrm{R} \$ 0,06$ por minuto. Devido aos benefícios de gratuidade e uso do vale-transporte e de percorrer maiores distâncias à um custo menor, era de se esperar que o valor do tempo para os usuários do ônibus fosse menor comparativamente com o modo privado. Além disso, como visto na Tabela 4.6, para as classes de renda domiciliares mais altas, o modo privado é mais frequentemente utilizado e, possivelmente, as pessoas incluídas nestas classes podem atribuir maior valor econômico ao tempo gasto em viagens.

Tanto o valor do tempo para o modo privado, como para o modo público, pode ser reflexo da característica geográfica da RMBS de ser longilínea. Isto gera tarifas de transporte público diferenciadas em função das distâncias percorridas de viagem, e o consumo maior de combustível para o modo privado devido às distâncias de viagem serem maiores. Desta forma, possivelmente, o valor do tempo na RMBS atribuído pelos viajantes deve ser maior do que o atribuído se a análise do valor do tempo fosse feita em uma única cidade.

As categorias consideradas de vínculo empregatício, VE2 (categoria de assalariado sem carteira, autônomo ou profissional liberal) e $V E 3$ (categoria de empregadores, donos de negócio familiar, trabalhadores familiares ou voluntários), apresentaram sinais negativos e parâmetros diferenciados na utilidade do modo público. A categoria VE3 que, por definição, pode requerer menor número de viagens do que a categoria $V E 2$, apresentou maior valor negativo do parâmetro estimado. Para os dois casos, a falta do recebimento do benefício do vale-transporte pode ter desestimulado o uso do ônibus.

No caso das classes de renda consideradas, $R D 1$ e $R D 2$, os usuários, por serem mais pobres, têm menos recursos para utilizar modos de transporte motorizados, mesmo que seja o modo público. Desta forma, estes usuários seriam obrigados a utilizar menos os modos motorizados pois os sinais e os pesos dos parâmetros estimados mostraram que quanto menor a renda, no caso da RMBS, maior a restrição ao uso do modo público. 


\subsubsection{Análise da especificação da função utilidade para o modo A Pé}

Para o modo a pé, o modelo gerou a função utilidade mostrada em (17):

$U_{\grave{a} p e ́}=2,22_{(24,74)}-3,69_{(-30,75)} x$ Tà pé $+1,37_{(3,98)} x E 4$

Em que:

- Ta pé é a variável contínua referente ao tempo de viagem gasto pelo modo a pé;

- E4 é a variável dummy referente ao indivíduo pertencer ou não à categoria do ensino fundamental $\left(1^{\mathrm{o}}\right.$ grau $-5^{\mathrm{a}}$ à $8^{\mathrm{a}}$ série $)$.

O parâmetro estimado do tempo, assim como para o modo bicicleta a ser analisado no próximo item, foi negativo e com peso maior quando comparado aos modos privado e público. Isto pode significar que o processo de decisão de escolha do modo de transporte é mais sensível ao tempo, em modos não-motorizados, do que em relação aos modos motorizados.

Com relação à variável E4, a política das Secretarias de Educação de recomendar que estudantes de ensino fundamental de escolas públicas sejam matriculados em escolas relativamente próximas às suas residências, pode justificar o efeito positivo na função utilidade do modo a pé da respectiva variável. Além disso, segundo a Tabela 4.7, que se refere à divisão modal segundo os motivos de viagem, o modo a pé é o mais frequente para aqueles que declararam que viajaram para realizar atividades relacionadas ao estudo.

\subsubsection{Análise da especificação da função utilidade para o modo Bicicleta}

O modelo gerou a seguinte função utilidade para o modo Bicicleta:

$U_{\text {bicicleta }}=-0,98_{(-6,44)}-2,30_{(-24,99)} \times$ Tbicicleta $+1,36_{(9,87)} \times A T 2-0,985_{(-3,30)} \times A T 3-0,488_{(-6,38)}$ $x$ AT5 $+1,28_{(15,22)} x$ sexo $+0,483_{(1,97)} x I D 2+0,251_{(2,27)} x I D 7+0,537_{(17,45)} x \mathrm{NBIC}+$ $0,302_{(2,96)} x \operatorname{IND}$

Em que:

- Tbicicleta é a variável contínua referente ao tempo de viagem gasto pelo modo bicicleta;

- $\quad$ AT2 é a variável dummy referente ao indivíduo pertencer, ou não, ao setor de atividade da Construção Civil; 
- $\quad A T 3$ é a variável dummy referente ao indivíduo pertencer ou não ao setor de atividade da Indústria;

- $\quad$ AT5 é a variável dummy referente ao indivíduo pertencer ou não ao setor de atividade de Serviços;

- Sexo é a variável dummy referente ao indivíduo ser do sexo masculino ou feminino;

- ID2 é a variável dummy referente ao indivíduo pertencer ou não à categoria de idade compreendida entre 12 e 18 anos;

- $\quad$ ID7 é a variável dummy referente ao indivíduo pertencer ou não à categoria de idade compreendida entre 18 e 50 anos;

- $\quad$ NBIC é a variável contínua referente ao número de bicicletas no domicílio;

- IND é a variável contínua referente ao indicador de disponibilidade de infraestrutura cicloviária para a viagem.

Como o esperado, a variável tempo de viagem apresentou coeficiente negativo na função utilidade da bicicleta. Comparando este coeficiente com os estimados para os modos privado e público, nota-se que a sensibilidade ao tempo é maior para os modos nãomotorizados, denotando o efeito da fadiga física que aumenta com o tempo de viagem. Desta maneira, pode-se afirmar que o decréscimo no tempo gasto nas viagens de bicicleta obtido, por exemplo, através da implantação de infraestrutura cicloviária, poderá significar maior aumento da quantidade demandada de transporte por bicicleta em áreas urbanas do que se fosse decrescido o mesmo tempo em viagens através do modo privado ou público.

Em relação às variáveis que dizem respeito ao setor de atividade, no qual as pessoas estão inseridas, os sinais foram negativos para as atividades de indústria e de serviços. Vale ressaltar que, na RMBS, a cidade que concentra atividades relacionadas à indústria é Cubatão/SP que, por sua vez, não possui ligação cicloviária com as demais cidades (ver Figuras 4.7 até 4.15). Neste caso, a localização espacial da atividade industrial, distante das cidades-dormitório, e a falta de infraestrutura de apoio ao ciclista, podem estar influenciando negativamente o uso da bicicleta. Aliado a isto, podem ser somados a falta de bicicletários próximo ao destino final da viagem, tanto para a atividade de indústria como para o setor de serviços, e de vestiários para que os usuários possam realizar higiene pessoal e de troca de vestimenta antes de trabalhar. 
A variável que diz respeito ao indivíduo pertencer ou não ao setor de atividade da construção civil apresentou coeficiente positivo igual à 1,36 na função utilidade da bicicleta. A Tabela 4.13, mostrada no capítulo 4, indicou que em domicílios onde o entrevistado trabalha na construção civil, por exemplo, apenas 8,96\% não possuem bicicleta. Nos demais setores, este percentual fica aproximadamente igual a $30 \%$. Diferentemente do que ocorre com os setores industrial e de serviços, as obras civis, tanto de pequeno porte como grande porte, disponibilizam espaço aos operários com chuveiros e há quase sempre espaço interno para guardar suas respectivas bicicletas.

A menor renda familiar de operários da construção civil em comparação com os demais setores, também influencia o maior uso da bicicleta, como é mostrado na Tabela 6.1. Há menos pessoas da construção civil em faixas de renda acima de $\mathrm{R} \$ 1.600,00$ e, portanto, sem condição financeira para usar modos de transporte mais caros para realizar as viagens urbanas.

Tabela 6.1 - Comparação entre setores da Construção Civil, Indústria e Serviços em relação à renda domiciliar em reais

\begin{tabular}{c|c|c|c}
\hline \multirow{2}{*}{$\begin{array}{c}\text { Faixa de Renda } \\
\text { Domiciliar (R\$) }\end{array}$} & \multicolumn{3}{|c}{$\%$} \\
\cline { 2 - 4 } & Construção Civil & Indústria & Serviços \\
\hline $0-800$ & 59,70 & 54,60 & 51,73 \\
$800-1600$ & 24,88 & 19,02 & 20,14 \\
$>1600$ & 15,42 & 26,38 & 28,12 \\
\hline
\end{tabular}

Salienta-se que tais aspectos relacionados ao uso da bicicleta pelos diversos setores de atividade necessitam, futuramente, de investigação por parte dos pesquisadores para que sejam descobertos os entraves ao uso da bicicleta entre as diversas profissões existentes no mercado.

O parâmetro estimado para o sexo do indivíduo mostrou a maior propensão de uso da bicicleta pelos homens, já que há o aumento na utilidade de 1,36, se a pessoa for do sexo masculino. Krizek et al. (2004), por exemplo, analisando cinco diferentes pesquisas, realizadas nos Estados Unidos, revelaram que a proporção de uso de bicicleta por homens em relação às mulheres é 2:1, ou seja, para cada 2 ciclistas homens há 1 ciclista mulher fazendo viagens de bicicleta nas cidades norte-americanas. As diferenças, em função do sexo, podem ser em decorrência dos propósitos de viagem e de percepções distintas sobre segurança ao 
pedalar. Por exemplo, as mulheres sentem insegurança ao pedalar devido aos riscos de assalto e ao trafegar em rotas sem infraestrutura cicloviária.

$\mathrm{Na}$ amostra reduzida da RMBS, utilizada para estimar o modelo, percebe-se a diferença, tanto no número de viagens de bicicleta como nos motivos de viagem, no uso da bicicleta entre homens e mulheres. A Tabela 6.2 mostra a comparação, somente das viagens feitas de bicicleta, entre os propósitos de viagem de ambos os sexos.

É possível verificar o maior uso da bicicleta entre os homens e que há diferença nos propósitos de viagem. Percentualmente, a mulher tende a utilizar mais a bicicleta para viagens com motivo de estudo e para realizar outras atividades do que o homem na RMBS.

Tabela 6.2 - Comparação entre Homem e Mulher, utilizando dados das viagens de bicicleta da amostra modificada da RMBS, em relação ao motivo da viagem

\begin{tabular}{c|c|c|c|c}
\hline Motivo da viagem & Homem & $\%$ & Mulher & $\%$ \\
\hline Trabalho & 454 & 47,24 & 98 & 40,16 \\
Escola & 26 & 2,71 & 26 & 10,66 \\
Outras atividades & 14 & 1,46 & 6 & 2,46 \\
Retornando para casa & 467 & 48,60 & 114 & 46,72 \\
Total & 961 & 79,75 & 244 & 20,25 \\
\hline
\end{tabular}

Já os coeficientes estimados para a idade, nas categorias entre 12 e 18 anos e 18 à 50 anos, foram positivos e com valores diferenciados. A categoria entre 18 e 50 anos foi criada a partir do resultado de modelos preliminares gerados, que mostraram que os grupos de idade de 18-30, 30-40 e 40-50 anos, tinham parâmetros estimados muito próximos.

Ortúzar et al. (2000), através de um experimento de preferência declarada em Santiago, Chile, utilizou o modelo logit binário para estimar as viagens feitas por bicicleta. No modelo, foram consideradas 2 variáveis em relação a idade, uma que representava o grupo entre 14 e 30 anos e a outra variável que representava as pessoas acima de 50 anos. Os valores dos parâmetros foram 0,2865 e -1,2120, respectivamente, para a análise da amostra do grupo de viajantes à pé, bicicleta, caronista e outros modos, o que demonstra o declínio do uso da bicicleta para pessoas com idade mais avançada. 
Manness (2012), utilizando a pesquisa domiciliar de viagem feita em âmbito nacional nos Estados Unidos em 2001 e modelos de escolha discreta, calculou a probabilidade de os domicílios terem a posse de 1, 2, 3, 4 ou mais bicicletas, ou nenhuma bicicleta, baseado em variáveis como faixa etária da população, tipo de moraria e se ela é própria ou não, tamanho da população da cidade, raça do indivíduo, renda anual em dólares, grau de instrução, posse de automóveis, entre outras variáveis. Segundo o autor, a posse de bicicletas é uma importante medida na análise comportamental de viagens de bicicleta pois é um importante indicador da propensão de uso da bicicleta em áreas urbanas.

Assim como há indícios de que, com o aumento da idade há menos propensão de uso da bicicleta, há também resultados que mostram que há diminuição da posse de bicicletas nos domicílios. Um dos resultados de parâmetros estimados por Manness (2012) mostrou que a faixa etária da população, nas categorias compreendidas entre 11 e 54 anos, apresentou parâmetros entre 0,23 e 0,75, e que entre 55-64 anos não foi estatisticamente significativo e que, acima de 65 anos, influencia negativamente, com valor igual a $-0,21$, na função utilidade da posse de bicicletas no domicílio. Portanto, a posse de bicicletas, segundo o estudo, diminuiu significamente com o aumento da idade.

Nesta análise, foi citado que a posse de bicicletas no domicílio pode variar em função do setor de atividade no qual o indivíduo está inserido. A Tabela 6.3 mostra que, além disso, ela pode variar em função da idade. A posse de bicicletas diminui para idades maiores, como pode ser percebido pela posse de bicicletas da classe de idade maior que 50 anos, onde é maior o percentual da posse igual à zero bicicleta no domicílio em comparação com as demais classes de idade.

Tabela 6.3 - Posse de bicicletas, em função da idade, na amostra modificada da RMBS

\begin{tabular}{|c|c|c|c|c|c|c|c|c|c|c|}
\hline \multirow{2}{*}{$\begin{array}{c}\text { Classes de } \\
\text { idade (em } \\
\text { anos) }\end{array}$} & \multicolumn{8}{|c|}{ Posse de bicicletas } & \multirow[b]{2}{*}{ Total } & \multirow[b]{2}{*}{$\%$} \\
\hline & $\mathbf{0}$ & $\%$ & 1 & $\%$ & 2 & $\%$ & $\begin{array}{l}3 \text { ou } \\
\text { mais }\end{array}$ & $\%$ & & \\
\hline $0-12$ & 5 & 62,50 & 2 & 25,00 & 1 & 12,50 & 0 & 0,00 & 8 & 0,16 \\
\hline $12-18$ & 14 & 17,72 & 26 & 32,91 & 18 & 22,78 & 21 & 26,58 & 79 & 1,62 \\
\hline $18-30$ & 460 & 27,15 & 671 & 39,61 & 366 & 21,61 & 197 & 11,63 & 1694 & 34,64 \\
\hline $30-40$ & 341 & 26,33 & 549 & 42,39 & 279 & 21,54 & 126 & 9,73 & 1295 & 26,48 \\
\hline $40-50$ & 283 & 25,45 & 436 & 39,21 & 265 & 23,83 & 128 & 11,51 & 1112 & 22,74 \\
\hline$>50$ & 253 & 36,04 & 257 & 36,61 & 133 & 18,95 & 59 & 8,40 & 702 & 14,36 \\
\hline
\end{tabular}


Desta forma, os valores positivos dos parâmetros estimados das variáveis AT2, ID2, ID7 e NBIC, na função utilidade da bicicleta, decorrem da maior propensão de uso da bicicleta, e também na posse de bicicletas no domicílio, por grupos de indivíduos inseridos na construção civil e/ou em idades compreendidas entre 12 e 50 anos.

O indicador de disponibilidade de infraestrutura cicloviária apresentou coeficiente igual à 0,302 e, como foi mostrado no capítulo anterior, no resultado do procedimento para comparação entre contagens do PCM e o modelo estimado para a RMBS, quanto maior a relação entre distância percorrida em ciclovias e/ou ciclofaixas e distância total entre origem e destino, maior é a posse de bicicletas no domicílio. O fato de dispor de infraestrutura de apoio ao ciclista na rota de viagem, ou seja, de maior segurança ao pedalar, deve incentivar a compra de bicicletas pelos moradores da RMBS.

Buehler e Pucher (2011) examinaram o impacto da implantação de ciclofaixas (do inglês, "bike lanes") e de ciclovias (do inglês, "bike paths") nos níveis de uso da bicicleta nas 100 maiores cidades norte-americanas. Diferentemente da Europa, segundo os autores, nos Estados Unidos é bastante comum considerar as ciclovias como espaços multi-uso de modos não-motorizados, ou seja, podem ser utilizados tanto por ciclistas como por pedestres, patinadores, skatistas, entre outras categorias. A análise, em nível agregado, foi baseada nos dados de comprimento de faixas e de ciclovias coletados, em cada cidade, no ano de 2008. Foi utilizado o modelo logit binário, que confirmou que as cidades, com grande quantidade de infraestrutura cicloviária construída, possuem níveis consideráveis de uso da bicicleta. Para tanto, a variável dependente na modelagem, níveis de uso da bicicleta, foi medida de duas formas: razão de viajantes de bicicleta em relação ao total de viagens, controlada tanto pelo número de trabalhadores em cada cidade como pelo tamanho da população. Já a variável independente utilizada no modelo, referente a ciclovias e ciclofaixas, foi o logaritmo da quantidade, para cada caso, de infraestrutura construída dividida por 100.000 habitantes. Outras variáveis como, por exemplo, densidade populacional, tipo de desenho urbano, porcentagem de estudantes, posse de automóveis, níveis de precipitação pluviométrica anual, número de dias abaixo de $32^{\circ} \mathrm{F}$ por ano, entre outras, também foram utilizadas no modelo. Os coeficientes obtidos pelo logit binário no estudo de Buehler e Pucher (2011), das variáveis relacionadas à infraestrutura cicloviária, foram iguais a 0,294, para milhas de ciclofaixas construídas por 100.000 habitantes e 0,215 , para milhas de ciclovias construídas por 100.000 
habitantes. Não é possível a comparação com o parâmetro obtido neste trabalho por serem conceitualmente diferentes. Além disso, o estudo difere por ser em nível agregado de informações, diferentemente do trabalho desenvolvido com os dados da RMBS, que foi proveniente de pesquisa das características socioeconômicas e de viagens individuais da amostra de domicílios da região metropolitana.

No entanto, é importante frisar que um estudo realizado em outra localidade chegou à conclusão de que a influência da implantação de infraestrutura cicloviária, tanto qualitativa como quantativamente, pode ocasionar em aumento do uso da bicicleta.

\subsection{Análise dos Cenários 1 e 2}

Ben-Akiva e Atherton (1977) apresentaram uma metodologia para predição de viagens urbanas após serem inseridas pequenas alterações em opções de modos de transportes como, por exemplo, medidas de incentivo à caronas em veículos particulares ("carpooling”). A metodologia é baseada em modelos desagregados de demanda por viagem, neste caso, o logit multinomial, e em dados da cidade de Washington, EUA. A variável dependente foi o modo de viagem reportado pelos entrevistados e as variáveis independentes foram características socioeconômicas, estimação de custo e tempo de viagem e uso e ocupação do solo da referida área urbana. Uma das análises, realizada em um corredor da cidade, foi feita comparando o número de viagens feitas antes (ano base foi 1970), por carros e ônibus, e depois (ano atual foi 1974), após as seguintes mudanças: construção de faixas preferenciais para uso de ônibus e veículos particulares em carpooling, com preferência no tráfego através do controle semafórico; medidas de controle de estacionamento de veículos no centro da cidade; e aumento do preço do combustível. O erro máximo da predição do modelo, comparado com a contagem volumétrica feita no corredor após as mudanças, foi de 13,5\%. Segundo os autores, o erro foi considerado pequeno e o modelo conseguiu capturar as mudanças comportamentais ocorridas no espaço de tempo decorrido.

No capítulo anterior foram conduzidas duas análises comparativas, em pontos da RMBS, através da construção de dois cenários. No Cenário 1, referente ao ano 2007, a análise comparativa ocorreu entre o número de viagens de bicicleta estimado pelo modelo de escolha discreta e o número expandido de viagens de bicicleta extraídos da $\mathrm{O} / \mathrm{D}$, já que não houve contagem volumétrica de ciclistas após a implantação de infraestrutura de apoio ao ciclista. 
No Cenário 2, a comparação foi realizada através da simulação para o ano de 2006, com modificações em variáveis socioeconômicas e do indicador de disponibilidade de infraestrutura cicloviária, e nova estimativa do número de viagens de bicicleta usando o modelo de escolha discreta e, desta vez, comparando com a contagem volumétrica de ciclistas registrada no PCM.

A Tabela 6.4 mostra o resultado dos Cenários 1 e 2 para todos os pontos de contagem considerados na análise. Todas as colunas foram numeradas e na coluna (2) há, entre parênteses, o número de viagens de bicicleta que foi expandido.

Tabela 6.4 - Resumo da comparação feita através dos Cenários 1 e 2

\begin{tabular}{|c|c|c|c|c|c|c|c|}
\hline \multirow[b]{2}{*}{ Item } & \multirow[b]{2}{*}{ Identificação } & \multicolumn{3}{|c|}{ Cenário 1 (2007) } & \multicolumn{3}{|c|}{ Cenário 2 (2006) } \\
\hline & & $\begin{array}{c}\text { Modelo } \\
\text { (1) } \\
\end{array}$ & \begin{tabular}{|c|} 
Viagens \\
Expandidas \\
$\left(\mathbf{N}^{\circ}\right.$ de viagens $)$ \\
$(2)$ \\
\end{tabular} & $\begin{array}{c}\% \\
\text { (1) } \times(2)\end{array}$ & $\begin{array}{c}\text { Modelo } \\
\text { (3) } \\
\end{array}$ & $\begin{array}{c}\text { PCM } \\
\text { (4) } \\
\end{array}$ & $\begin{array}{c}\% \\
\text { (3) } \times(4)\end{array}$ \\
\hline 1 & CICLOVIA 1 & 979 & $1135(20)$ & $-15,93$ & 815 & 762 & 6,96 \\
\hline 3 & CICLOVIA 2 & 968 & $935(14)$ & 3,53 & 841 & 492 & 70,93 \\
\hline 2 & CICLOVIA 3 & 1414 & $1212(17)$ & 16,67 & 1049 & 1194 & $-13,82$ \\
\hline 4 & CICLOVIA 4 & 1182 & $1060(17)$ & 11,51 & 874 & 1013 & $-15,90$ \\
\hline 5 & CICLOVIA 5M & 854 & $857(16)$ & $-0,35$ & 667 & 564 & 18,26 \\
\hline 6 & CICLOVIA 5T & 955 & $745(15)$ & 28,19 & 703 & 378 & 85,98 \\
\hline 7 & CICLOFAIXA 6 & 544 & $708(15)$ & $-30,15$ & 395 & 403 & $-2,03$ \\
\hline 8 & CICLOFAIXA 7 & 1155 & $1164(28)$ & $-0,78$ & 963 & 948 & 1,58 \\
\hline 9 & CICLOFAIXA 8 & 1105 & $1251(23)$ & $-13,21$ & 928 & 582 & 59,45 \\
\hline 10 & CICLOFAIXA 9 & 503 & $427(10)$ & 17,80 & 378 & 360 & 5,00 \\
\hline 11 & CICLOVIA 10 & 1061 & $1028(16)$ & 3,21 & 788 & 852 & $-8,12$ \\
\hline Totais & -- & 10720 & 10522 & 1,88 & 8401 & 7548 & 11,30 \\
\hline
\end{tabular}

Não é de se esperar que o modelo logit multinomial, estimado através da amostra reduzida da RMBS, represente identicamente a contagem real de ciclistas pois pode haver outras variáveis, não utilizadas neste trabalho, como por exemplo, a oferta e caracterização de postos de trabalho ou a presença de bicicletários nas zonas de tráfego, que poderiam diminuir a diferença percentual na previsão. Salienta-se que os exemplos citados não foram utilizados devido à dificuldade na obtenção de dados que os representassem adequadamente. Além disso, a exclusão de viagens intrazonais, ou seja, de viagens com distâncias menores e que, por este motivo, mais interessantes ao uso da bicicleta, podem ter contribuído para a diferença entre os resultados. 
Não há valores que possam ser usados como referência para dizer se houve acerto, ou não, na previsão de demanda gerada pelo modelo de escolha discreta, com dados desagregados, em comparação com dados de contagem volumétrica em determinados pontos. Ben-Akiva e Atherton (1977), por exemplo, consideraram pequena a diferença de $13,5 \%$ entre a demanda prevista pelo modelo logit e a contagem real.

Particularmente no Cenário 1, a diferença entre as duas estimativas pode ter sido causada pelo reduzido número de viagem na amostra e pela aleatoriedade a que toda Pesquisa O/D está sujeita. Conforme a coluna (2) da Tabela 6.4, este número variou entre 10 e 28 casos. Portanto, como não havia a contagem volumétrica nos pontos após a implantação das ciclovias e/ou ciclofaixas, a Pesquisa O/D foi utilizada e, consequentemente, surgiram imprecisões na previsão da demanda de viagens de bicicleta selecionadas da O/D.

No entanto, tal fato não impediu que a análise comparativa entre as duas previsões de demanda cicloviária, feita no Cenário 1, seja considerada como válida e, em sequência ao detalhamento do método, o Cenário 2 foi construído e a comparação, desta vez, realizada entre os valores da estimativa através do modelo de escolha discreta e a contagem volumétrica registrada no PCM.

Em relação ao Cenário 2, as divergências entre os valores fornecidos pelo modelo e a contagem real de ciclistas registradas no PCM, podem ter sido causadas pelos seguintes fatores:

- A demanda cicloviária, na época em que não havia ciclovias e/ou ciclofaixas, poderia estar dividida entre as ruas paralelas à via que recebeu a infraestrutura de apoio ao ciclista;

- A expansão das contagens volumétricas, que foram feitas em 10 minutos, para a unidade de tempo "hora" pode não estar condizente com a realidade.

A partir da análise das Figuras 5.4 até 5.14, é possível notar quais vias, onde ficavam localizados os pontos de contagem, possuíam vias paralelas que poderiam servir como rotas alternativas para os ciclistas. As Figuras 5.5, 5.8, 5.9 e 5.12 mostraram pontos onde havia concorrência na escolha da rota preferencial pelos ciclistas. 


\subsubsection{Análise das viagens da $O / D$ consideradas nos pontos de contagem}

Tanto para uso tanto no Cenário 1 como no Cenário 2, a seleção das viagens na Pesquisa O/D que passam pelos pontos de contagem foi necessária. Foram consideradas as velocidades dentro e fora da rede cicloviária e calculado o horário em que o indivíduo passaria no ponto de contagem. Caso a viagem estivesse dentro do intervalo horário preestabelecido, todos com duração de 1 hora, o par O/D era selecionado para a análise.

Para o melhor entendimento acerca das viagens da O/D consideradas nos pontos de contagem, foram tecidos alguns comentários baseado nas Figuras 6.1 e 6.2 dos pontos de contagem e nas informações obtidas através do banco de dados. Os pontos foram agrupados para melhor interpretação dos resultados alcançados através do método proposto.

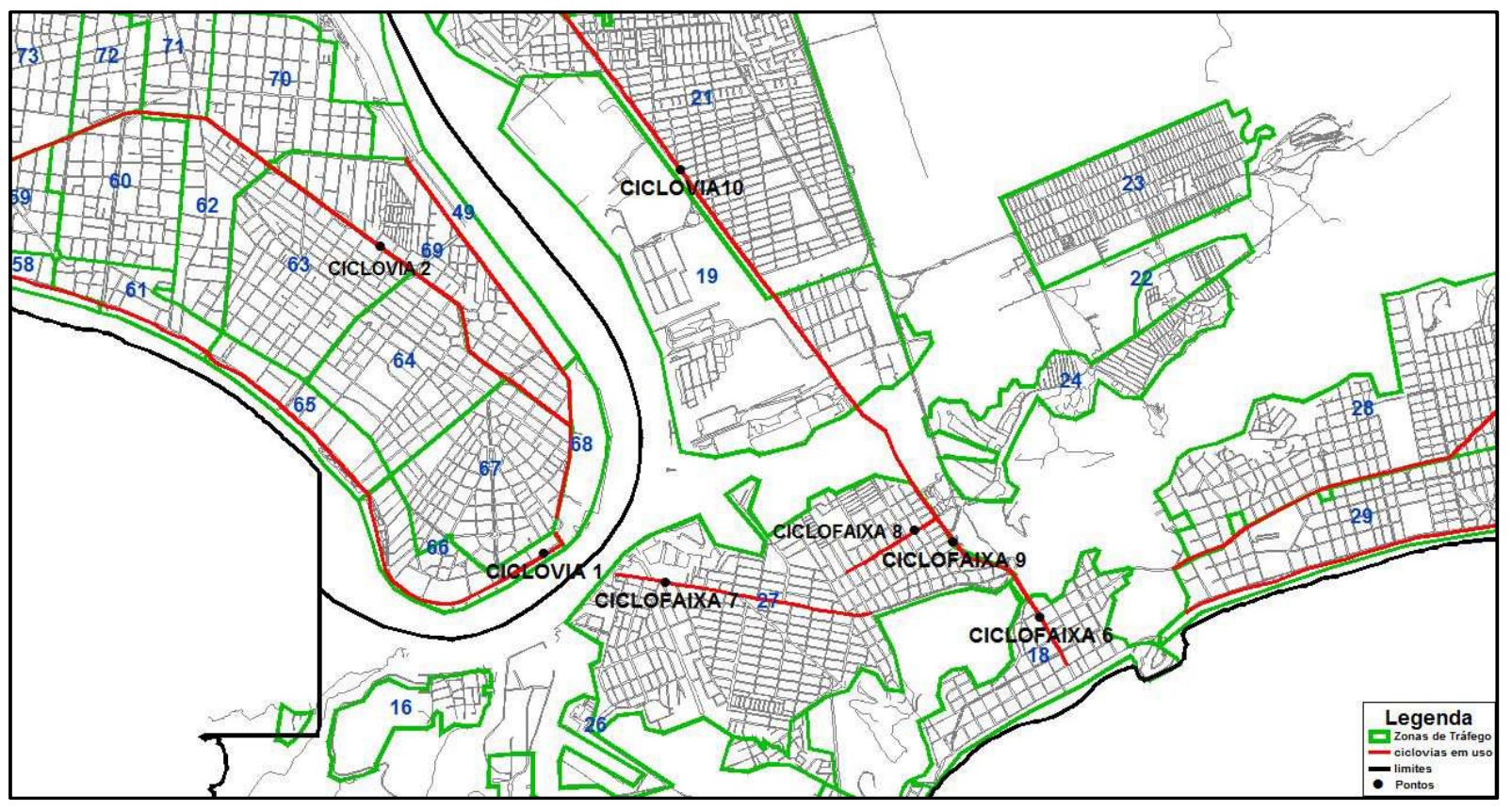

Figura 6.1 - Distribuição espacial dos pontos Ciclovia 1 e 10 e Ciclofaixa 6, 7, 8 e 9 


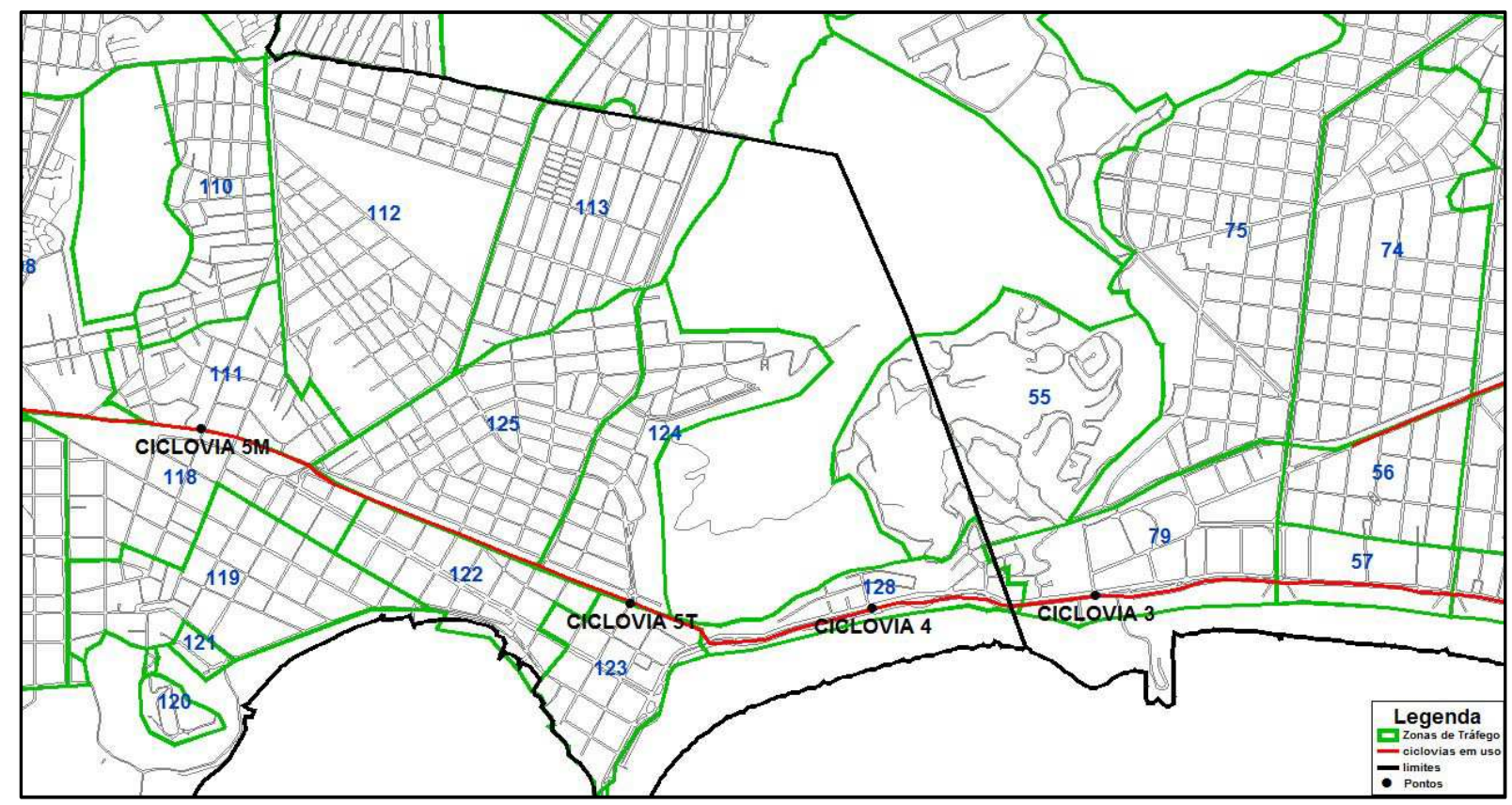

Figura 6.2 - Distribuição espacial dos pontos Ciclovia 3, 4, 5T e 5M

\section{- Pontos Ciclovia 1 e Ciclofaixa 7}

A Figura 6.1 mostra os 2 pontos localizados bem próximos da travessia de balsa entre Santos-SP e Guarujá-SP e, por esse motivo, podem ser considerados pontos intermediários de passagem obrigatórios. Há viagens, que cruzam os pontos de contagem, entre zonas de tráfego da cidade de Santos-SP, Guarujá-SP, Cubatão-SP, São Vicente-SP, Praia Grande-SP e Mongaguá-SP. Tanto para o Cenário 1 quanto para o Cenário 2, a comparação mostrou que o modelo de escolha discreta estimou adequadamente a demanda cicloviária nestes pontos de contagem.

Nas viagens de bicicleta selecionadas da Pesquisa O/D foi possível notar o fluxo no sentido Santos-SP/Guarujá-SP no ponto Ciclovia 1 e o contrário no ponto Ciclofaixa 7. Isto é devido à diferença nos horários dos intervalos considerados para análise. Conforme mostrou a Tabela 5.3, o intervalo no ponto Ciclovia 1 foi entre 17:56 e 18:56hs e no ponto Ciclofaixa 7 entre 6:00 e 7:00hs. Neste caso, a maioria dos viajantes de bicicleta reside em Guarujá-SP e trabalha em Santos-SP. No entanto, houve casos em que, devido à extensão de infraestrutura de apoio existente em toda a orla de Santos-SP, Praia Grande-SP e parte de São Vicente-SP, os ciclistas realizaram a viagem a partir de Praia Grande-SP, considerada atualmente como 
cidade-dormitório, até a cidade de Guarujá-SP, totalizando distância aproximadamente igual à $25 \mathrm{~km}$ para chegar ao destino da viagem.

A média da distância total percorrida e da distância em ciclovia e/ou ciclofaixa das 20 viagens de bicicleta que passam pelo ponto Ciclovia 1 foram iguais à 14,68km e 11,20 km, respectivamente. Já para o ponto Ciclofaixa 7, as médias das 28 viagens de bicicleta selecionadas da O/D foram 15,81km, para a distância total percorrida, e 12,36km para o trecho em ciclovia e/ou ciclofaixa. É possível perceber que os ciclistas percorrem distâncias totais consideráveis usando bicicleta e, na maioria dos casos, dispõem da infraestrutura de apoio ao ciclista.

Desta forma, o indicador de infraestrutura cicloviária é superior a 0,5, com exceção das viagens originadas e destinadas a Cubatão-SP. Vale ressaltar que, a atividade industrial se concentra, principalmente, nesta cidade e, segundo o modelo de escolha discreta estimado, o parâmetro na função utilidade para o setor de atividade industrial foi negativo.

\section{- Pontos Ciclovia 3 e Ciclovia 4}

Os pontos, de acordo com a Figura 6.2, estão muito próximos entre si, porém, em municípios diferentes. Apesar disso, o resultado mostrou que há diferença, tanto na quantidade de viagens quanto nas zonas de tráfego que formaram os pares $\mathrm{O} / \mathrm{D}$, devido aos horários diferenciados que compuseram o intervalo de 1 hora para comparação de resultados.

Pelo ponto Ciclovia 3 passaram 150 viagens, no intervalo entre 16:55 e 17:55hs, que expandidas, totalizaram 1414 viagens segundo a previsão pelo modelo de escolha discreta no Cenário 1 e 1049 no Cenário 2, respectivamente. Já pelo ponto Ciclovia 4, entre 17:20 e 18:20hs, foram 216 viagens que expandidas totalizaram 1182 no Cenário 1 e 874 no Cenário 2. Salienta-se que o cálculo do total de viagens expandidas é baseado na probabilidade, de cada indivíduo, de realizar a viagem entre as alternativas de modo de viagem disponíveis multiplicado pelo fator de expansão inerente à cada par $\mathrm{O} / \mathrm{D}$, obtido através do procedimento mostrado no detalhamento do método. 
$\mathrm{O}$ fato de os pares $\mathrm{O} / \mathrm{D}$ mais distantes entre si e com menor população residente nas respectivas zonas de tráfego terem sido mais comuns nas viagens que passaram pelo ponto Ciclovia 4 no intervalo de 1 hora, ocasionou média inferior do fator de expansão em relação ao ponto Ciclovia 3. Por exemplo, é possível notar, através da Figura 5.6, zonas de tráfego de Peruíbe-SP, município localizado mais ao oeste da RMBS e o terceiro menos populoso (de acordo com a Tabela 4.1), que passaram pelo respectivo ponto. Desta forma, apesar de haver mais viagens que passaram pelo ponto Ciclovia 4, o total expandido das viagens no ponto Ciclovia 3 foi maior porque os fatores de expansão das viagens que passam pelo ponto são maiores.

Salienta-se que nos demais pontos de contagem não houve nenhuma disparidade entre quantidade de viagens na O/D e o valor expandido destas viagens para que justificasse a análise mais detalhada dos valores dos fatores de expansão dos respectivos pares $\mathrm{O} / \mathrm{D}$, como foi feito entre os pontos Ciclovia 3 e Ciclovia 4.

O ponto Ciclovia 4 foi um dos dois pontos que apresentou a contagem volumétrica de ciclistas feita em 1 hora. $\mathrm{O}$ fato de a demanda cicloviária prevista pelo modelo ter ficado relativamente próximo da realidade neste ponto, sem a interferência da expansão da contagem volumétrica de 10 minutos para 1 hora, corrobora para a afirmação da hipótese de que o modelo de escolha discreta serve para avaliar e planejar a implantação de ciclovias e/ou ciclofaixas em áreas urbanas. No ponto Ciclovia 3 a demanda cicloviária também foi reproduzida adequadamente pelo modelo de escolha discreta.

Com relação as viagens feitas de bicicleta, as 17 viagens selecionadas para análise do ponto Ciclovia 3 apresentaram média da distância total percorrida igual à 15,46 km e 10,68km para a média da distância percorrida em ciclovia. Já para o ponto Ciclovia 4, as médias foram $13,82 \mathrm{~km}$ e $9,42 \mathrm{~km}$, respectivamente.

Novamente o indicador de infraestrutura cicloviária mostrou que, na maioria dos casos, metade da distância percorrida entre origem e destino pode ser feita nas ciclovias. Apenas os pares formados a partir de zonas de tráfego de Peruíbe e alguns com destino à zona central de Santos-SP tinham indicador inferior à 0,50 . 


\section{- Pontos Ciclovia 2, Ciclovia 5M, Ciclovia 5T e Ciclofaixa 8}

Os pontos de contagem, mostrados nas Figuras 6.1 e 6.2 apresentaram características em comum de terem vias paralelas à via onde houve a contagem volumétrica de ciclistas e que, posteriormente, recebeu a infraestrutura de apoio ao ciclista. Desta forma, nestes pontos o resultado da estimativa da demanda cicloviária pelo modelo de escolha discreta, através da construção do Cenário 2, foi maior do que a contagem de ciclistas registradas no PCM.

No caso da Ciclovia 2, os pares O/D que formaram viagens que passaram pelo ponto tinham, como origem ou destino, os seguintes setores da RMBS: zona portuária (ZT 69), região central (ZT 45) e travessia da balsa na cidade de Santos-SP; e zonas de tráfego das cidade de São Vicente-SP, Cubatão-SP e Guarujá-SP. Ambas ligações, na época da contagem volumétrica do PCM, poderiam ser feitas em vias paralelas que poderiam torná-las até mais rápidas. Desta forma, a diferença superior à $70 \%$ entre a previsão do modelo e a contagem real de ciclista pode ter sido, essencialmente, causada pela separação da demanda nas respectivas vias. Vale ressaltar, novamente, a presença de pares O/D onde o indicador foi inferior à 0,5 , originados ou destinados à cidade de Cubatão-SP.

A ciclovia, onde estavam localizados os pontos Ciclovia 5M e 5T, foi construída para atender o município de São Vicente-SP e fazer sua ligação com a cidade de Santos-SP. Os municípios de Peruíbe-SP, Mongaguá-SP, Itanhaém-SP e a maioria das zonas de tráfego de Praia Grande-SP, localizados à oeste da RMBS, utilizam rota diferente para chegar à cidade de Santos-SP. Desta forma, os pares O/D formados foram essencialmente de ligações entre zonas de tráfego de São Vicente-SP e entre a cidade e Santos-SP e com sentidos de fluxo diferenciados. Pela manhã o sentido de maior contagem é de São Vicente-SP para Santos-SP e à tarde o inverso. Salienta-se que mais de $80 \%$ das viagens selecionadas para análise, para os dois casos, apresentaram indicador de infraestrutura cicloviária superior à 0,5.

O ponto Ciclofaixa 8, localizado na cidade do Guarujá-SP, de acordo com a Figura 6.2, foi localizado na rota compreendida entre a travessia da balsa e o Distrito de Vicente de Carvalho (ZTs 19, 20 e 21) e de bairros residenciais existentes nas zonas de tráfego 22 e 23. O distrito de Vicente de Carvalho pode ser considerado como uma "cidade", dentro do próprio município de Guarujá-SP, pois há a presença considerável de atividade econômica e também 
de residências. Os pares O/D formados originam-se das ligações entre Santos-SP, CubatãoSP, São Vicente-SP e Praia Grande-SP com as duas áreas pertencentes à Guarujá-SP. Assim como os demais pontos de contagem, onde apareceram a ligação com Cubatão-SP, o indicador de infraestrutura cicloviária foi inferior a 0,5.

A Tabela 6.5 mostra o número de viagens de bicicleta selecionadas e as médias das distâncias totais percorridas e de distâncias percorridas em ciclovias e/ou ciclofaixas para estes pontos.

Tabela 6.5 - Número de viagens de bicicleta e distâncias médias totais percorridas e em ciclovia e/ou ciclofaixas (em $\mathrm{km}$ ) nos respectivos pontos de contagem

\begin{tabular}{l|c|c|c}
\hline Ponto & $\begin{array}{c}\text { Número de } \\
\text { viagens de } \\
\text { bicicleta }\end{array}$ & $\begin{array}{c}\text { Distância média } \\
\text { total percorrida } \\
(\mathbf{e m ~} \mathbf{~ k m})\end{array}$ & $\begin{array}{c}\text { Distância média em } \\
\text { ciclovia e/ou ciclofaixa } \\
(\mathbf{e m ~ k m})\end{array}$ \\
\hline Ciclovia 2 & 14 & 15,24 & 12,07 \\
\hline Ciclovia 5M & 16 & 10,18 & 6,61 \\
\hline Ciclovia 5T & 15 & 10,83 & 7,64 \\
\hline Ciclofaixa 8 & 23 & 16,12 & 12,15 \\
\hline
\end{tabular}

É possível notar a diferença nas médias das distâncias totais percorridas entre as viagens de bicicleta que passam pelos pontos. $\mathrm{O}$ fato de a ciclovia que passa pelos pontos Ciclovia 5M e 5T atender apenas os fluxos provenientes das zonas de tráfego de São VicenteSP e, em alguns casos, da ligação São Vicente-SP e Santos-SP, reduz a distância total percorrida em comparação com os demais pontos.

Os ciclistas contabilizados pelos pontos de contagem Ciclovia 2 e Ciclofaixa 8 realizaram viagens entre a região central de Santos-SP e o município de Guarujá-SP e viceversa. Isto resultou em distâncias maiores a serem vencidas do que os ciclistas contabilizados pelos pontos Ciclovia 5M e 5T.

De acordo com a Figura 6.2, é possível perceber que os pontos Ciclovia 3 e Ciclovia 4 estão relativamente próximos dos pontos Ciclovia $5 \mathrm{M}$ e $5 \mathrm{~T}$ e, no entanto, as pessoas que utilizam as respectivas ciclovias são diferentes, o que resultou em médias das distâncias totais percorridas maiores para os pontos Ciclovia 3 e Ciclovia 4. Estes pontos contabilizaram os ciclistas que utilizam a rota entre os municípios de Peruíbe-SP, Mongaguá-SP, Itanhaém-SP e 
a maioria das zonas de tráfego de Praia Grande-SP até a cidade de Santos-SP, e os pontos Ciclovia 5M e 5T os fluxos provenientes entre as zonas de tráfego de São Vicente-SP e, em casos, entre São Vicente-SP e Santos-SP.

\section{- Pontos Ciclofaixa 6, Ciclofaixa 9 e Ciclovia 10}

Contagens realizadas nestes pontos serviram como parâmetro para implantação do corredor cicloviário, na cidade de Guarujá-SP, ligando a região central (ZT 18) ao Distrito de Vicente de Carvalho e vice-versa. É possível notar, através da Figura 6.1, que a via, inicialmente chamada de Av. Puglisi, no ponto Ciclofaixa 6, e depois chamada de Av. Santos Dumont nos outros pontos, representa o único acesso entre as duas áreas do município.

Como não há, praticamente, dúvidas em relação à rota tomada pelos ciclistas, o modelo estimado apresentou erros, considerados pequenos, na comparação com as previsões da demanda cicloviária nestes 3 pontos no Cenário 2 .

Também, o fato de a Ciclofaixa 6, outro ponto em que a contagem volumétrica de ciclistas foi feita durante o período de 1 hora, ter apresentado a diferença de apenas 8 ciclistas a menos na estimativa usando o modelo no referido período, contribuiu na aceitação de que o modelo com os dados da RMBS estimou adequadamente a demanda cicloviária.

A Tabela 6.6 mostra o número de viagens de bicicleta selecionadas e as médias das distâncias totais percorridas e de distâncias percorridas em ciclovias e/ou ciclofaixas para estes pontos. Na maioria dos casos, as viagens de bicicleta selecionadas foram originadas e destinadas às zonas de tráfego do próprio município de Guarujá-SP e isto resultou em distâncias percorridas menores em comparação com pontos localizados em áreas onde foi possível identificar ciclistas que realizam viagens intermunicipais como, por exemplo, os pontos Ciclovia 1, Ciclofaixa 7, Ciclovia 3, Ciclovia 4, Ciclovia 2 e Ciclofaixa 8. 
Tabela 6.6 - Número de viagens de bicicleta e distâncias médias totais percorridas e em ciclovia e/ou ciclofaixas (em $\mathrm{km}$ ) nos respectivos pontos de contagem

\begin{tabular}{c|c|c|c}
\hline Ponto & $\begin{array}{c}\text { Número de } \\
\text { viagens de } \\
\text { bicicleta }\end{array}$ & $\begin{array}{c}\text { Distância média } \\
\text { total percorrida } \\
(\mathbf{e m ~} \mathbf{~ k m})\end{array}$ & $\begin{array}{c}\text { Distância média em } \\
\text { ciclovia e/ou ciclofaixa } \\
\mathbf{( e m} \mathbf{~ k m})\end{array}$ \\
\hline Ciclofaixa 6 & 15 & 8,19 & 6,18 \\
\hline Ciclofaixa 9 & 10 & 9,86 & 7,26 \\
\hline Ciclovia 10 & 16 & 11,26 & 9,19 \\
\hline
\end{tabular}

\subsubsection{Análise das modificações em variáveis socioeconômicas e do indicador de infraestrutura cicloviária}

O resultado do procedimento para construção do Cenário 2, apresentado no capítulo anterior, mostrou que foram consideradas modificações em 3 variáveis no período compreendido entre a contagem do PCM e o início das entrevistas domiciliares da Pesquisa O/D da RMBS. As considerações feitas nestas variáveis surtiram efeito nos fluxos de ciclistas obtidos através do modelo de escolha discreta.

Foi possível perceber a variação no número de bicicletas no domicílio em função do indicador de infraestrutura cicloviária. $\mathrm{O}$ indicador, por sua vez, foi considerado igual à zero na estimação do volume de ciclistas na época da contagem do PCM devido ao fato de ainda não haver ciclovias e/ou ciclofaixas.

O rápido crescimento da construção civil, experimentado principalmente entre 2004 e 2008 e de 2010 até os dias atuais, têm causado o incremento da demanda cicloviária, não só na RMBS, como na maioria das cidades brasileiras. É possível perceber o volume de bicicletas atraído pelas obras da construção civil espalhadas em qualquer cidade.

A ideia inicial seria a utilização de um indicador que representasse o número de pessoas empregadas em obras de construção civil, na época da contagem do PCM, por zonas de tráfego. Através da discriminação dos alvarás de construção expedidos pelas prefeituras, provavelmente, seria possível a construção deste indicador. No entanto, o valor adotado de decréscimo de $20 \%$, baseado no aumento de pessoas empregadas no Estado de São Paulo entre os anos de 2006 e 2007, aparentemente, foi adequado para diminuição do fator de 
expansão para empregados pertencentes ao setor da construção civil existentes no banco de dados da O/D da RMBS.

A análise dos parâmetros estimados para as 3 variáveis denota que a variável AT2, referente à pessoa pertencer ou não à classe de empregados da construção civil, possui peso maior na escolha do modo bicicleta do que o número de bicicletas no domicílio e o indicador de disponibilidade de infraestrutura cicloviária. A variável AT2 apresentou parâmetro igual à 1,36 contra 0,537 do número de bicicletas no domicílio e 0,302 do indicador de infraestrutura cicloviária.

Com o intuito de analisar os percentuais de indivíduos pertencentes aos setores da construção civil (AT2), indústria (AT3) e serviços (AT5), que compuseram a função utilidade do modo bicicleta, nas respectivas viagens contabilizadas nos pontos de contagem, foi construída a Tabela 6.7.

Tabela 6.7 - Percentuais de indivíduos nos setores de atividade AT2, AT3 e AT5 nas respectivas viagens contabilizadas nos pontos de contagem

\begin{tabular}{c|c|c|c|c|c|c|c}
\hline \multirow{2}{*}{ Ponto } & \multicolumn{2}{|c|}{$\begin{array}{c}\text { Percentual de indivíduos nos } \\
\text { setores de atividade (\%) }\end{array}$} & \multirow{2}{*}{ Ponto } & \multicolumn{2}{c}{$\begin{array}{c}\text { Percentual de indivíduos nos } \\
\text { setores de atividade (\%) }\end{array}$} \\
\cline { 2 - 4 } \cline { 7 - 9 } & AT2 & AT3 & AT5 & & AT2 & AT3 & AT5 \\
\hline Ciclovia 1 & 8,22 & 1,37 & 54,79 & Ciclofaixa 6 & 8,33 & 2,08 & 39,58 \\
\hline Ciclovia 2 & $\mathbf{1 , 3 3}$ & $\mathbf{1 0 , 6 7}$ & $\mathbf{4 6 , 6 7}$ & Ciclofaixa 7 & $\mathbf{5 , 9 4}$ & $\mathbf{6 , 9 3}$ & $\mathbf{5 3 , 4 7}$ \\
\hline Ciclovia 3 & 10,67 & 0,00 & 41,33 & Ciclofaixa 8 & $\mathbf{3 , 8 0}$ & $\mathbf{5 , 0 6}$ & $\mathbf{5 0 , 6 3}$ \\
\hline Ciclovia 4 & 7,32 & 1,22 & 50,00 & Ciclofaixa 9 & 17,02 & 2,13 & 46,81 \\
\hline Ciclovia 5M & 5,26 & 2,26 & 46,62 & Ciclovia 10 & 2,50 & 1,25 & 41,25 \\
\hline Ciclovia 5T & 3,33 & 2,22 & 55,00 & & & & \\
\hline
\end{tabular}

O percentual de indivíduos pertencentes ao setor de serviços (AT5), que contribuiu com o valor de - 0,488 na função utilidade do modo bicicleta, foi o maior em comparação com os demais setores. Medidas de apoio ao uso da bicicleta conhecendo melhor as características intrínsecas de quem está inserido neste setor de atividade, provavelmente, reverteria o quadro negativo existente.

Foi discutido, anteriormente, a respeito das viagens notadas nos pontos de contagem. Especificamente, nos tópicos relacionados aos pontos: Ciclovia 1 e Ciclofaixa 7; e Ciclovia 2, 
Ciclovia 5M, Ciclovia 5T e Ciclofaixa 8; foi mencionado que o indicador de infraestrutura, para viagens originadas, ou destinadas, ao município de Cubatão-SP possuíam indicador inferior à 0,5 . De posse da Tabela 6.5, é possível perceber que a rota que passa pelos pontos Ciclofaixa 7, Ciclovia 2 e Ciclofaixa 8, em destaque na Tabela, é comum aos industriários (AT3) que residem em Guarujá-SP e trabalham em Cubatão-SP.

Somente o ponto Ciclovia 1, adjacente ao ponto Ciclofaixa 7 , apresenta percentual de trabalhadores da indústria bastante inferior aos demais. O motivo da diferença é o horário de passagem no ponto Ciclovia 1, compreendido entre 17:56 e 18:56hs, que não captou estas viagens. Em muitas indústrias/fábricas, o término do expediente ocorre em torno das 18:00hs e, pelo tempo gasto entre o horário de saída na origem até o ponto de passagem, é possível que o indivíduo tenha passado pelo ponto de contagem depois das 18:56hs e, portanto, não tenha sido capturado para a análise.

Nos outros pontos de contagem, os períodos foram das 6:02 até 7:02hs (Ciclovia 2) e 6:00 até 7:00hs (Ciclofaixa 7 e 8), diferentemente do ponto Ciclovia 1, puderam captar as viagens dos industriários.

Os empregados do setor da indústria apresentaram coeficiente estimado igual à $-0,985$ na função utilidade do modo bicicleta, portanto, valor duas vezes superior ao parâmetro estimado para quem pertence ao setor de serviços. O fato de as viagens até Cubatão-SP, devido à localização fora do eixo horizontal das demais cidades da RMBS e da falta de ligação de infraestrutura de apoio ao ciclista, aliado à remuneração maior do setor, contribui para que elas sejam feitas preferencialmente por outros modos de transporte em detrimento do uso da bicicleta.

De acordo com a Tabela 4.11, no banco de dados da O/D utilizado, cerca de 32,58\% dos domicílios possuíam 2 ou mais bicicletas e este percentual, em decorrência do procedimento para redução do número de bicicletas em função do indicador de infraestrutura cicloviária, sofreu variação entre a contagem do PCM e o início das entrevistas domiciliares da O/D. A Tabela 6.8 mostra a distribuição percentual da posse de bicicletas nos domicílios nas viagens que passaram por cada ponto. 
Tabela 6.8 - Percentuais do número de bicicletas no domicílio nas viagens que passaram pelos pontos analisados

\begin{tabular}{|c|c|c|c|c|c|c|c|}
\hline \multirow[t]{2}{*}{ Ponto } & \multicolumn{3}{|c|}{$\begin{array}{c}\mathrm{N}^{0} \text { de bicicletas no domicílio } \\
\text { em \% }\end{array}$} & \multirow[t]{2}{*}{ Ponto } & \multicolumn{3}{|c|}{$\begin{array}{c}\mathrm{N}^{\circ} \text { de bicicletas no domicílio } \\
\text { em } \%\end{array}$} \\
\hline & O ou 1 & 2 & 3 ou mais & & O ou 1 & 2 & 3 ou mais \\
\hline Ciclovia 1 & 54,79 & 17,81 & 27,40 & Ciclofaixa 6 & 62,50 & 31,25 & 6,25 \\
\hline Ciclovia 2 & 48,00 & 28,00 & 24,00 & Ciclofaixa 7 & 45,54 & 28,71 & 25,74 \\
\hline Ciclovia 3 & 66,00 & 24,67 & 9,33 & Ciclofaixa 8 & 46,84 & 21,52 & 31,65 \\
\hline Ciclovia 4 & 71,55 & 20,73 & 7,72 & Ciclofaixa 9 & 38,30 & 38,30 & 23,40 \\
\hline Ciclovia 5M & 70,68 & 18,80 & 10,53 & Ciclovia 10 & 48,75 & 32,50 & 18,75 \\
\hline Ciclovia 5T & 74,44 & 18,89 & 6,67 & & & & \\
\hline
\end{tabular}

Analisando a Tabela 6.8, nota-se que, nos pontos Ciclovia 2, Ciclofaixa 7, 8, 9 e 10, em destaque, mais da metade das viagens sofreram diminuição da posse de bicicleta no domicílio através da modificação feita para construção do Cenário 2. Com exceção dos pontos Ciclovia 2 e Ciclofaixa 8, que estavam em locais onde havia a presença de vias adjacentes que competiam pela preferência dos ciclistas, o modelo de escolha discreta estimou adequadamente a demanda cicloviária no Cenário 2.

Salienta-se que as viagens consideradas nos pontos foram realizadas pelas 4 alternativas de modo de viagem e, mesmo que o indivíduo não tenha tido a intenção de mudar de modo de viagem, a infraestrutura de apoio ao ciclista foi disponibilizada para todos e foi considerada no cálculo das probabilidades individuais do modelo logit multinomial. Acreditase que a modificação proposta para o número de bicicletas atingiu pelo menos aqueles indivíduos que, uma vez ou outra, podem utilizar tanto a nova bicicleta adquirida como a ciclovia implantada, ou ciclofaixa, para realizar viagens no dia-a-dia.

\subsection{Discussões dos Resultados}

Salvo algumas exceções, os resultados indicam que as funções utilidade das alternativas de modo de viagem consideradas permitem estimar satisfatoriamente a demanda cicloviária nos pontos de contagem ou em quaisquer pontos da malha urbana.

Como havia informações de contagem volumétrica de ciclistas anterior ao banco de dados utilizado para estimar o modelo de escolha discreta, foi necessário fazer a estimativa da 
demanda cicloviária ao inverso, ou seja, retroceder no tempo após verificar e modificar os valores das variáveis a fim de refletir o cenário do ano de 2006.

A função utilidade do modo bicicleta, mostrada na Equação (18), contém as variáveis que foram estatisticamente significativas na modelagem. O tempo de viagem, assim como nas demais alternativas, foi negativo. Através da comparação dos valores dos parâmetros do tempo de viagem, é possível constatar a maior influência deste parâmetro em modos nãomotorizados.

As variáveis que dizem respeito ao sexo e a idade, entre 12-18 anos e 18-50 anos, foram importantes para o uso da bicicleta. Na RMBS, assim como num estudo feito em outra localidade (KRIZEK ET AL., 2004), as diferenças, em função do sexo, podem ser em decorrência dos propósitos de viagem e de percepções distintas sobre segurança ao pedalar. Já em relação a idade, o fato de a bicicleta exigir a propulsão humana ao pedalar, faz com que grande parte da população que o utiliza seja composta por pessoas mais jovens.

Os setores de atividade no qual as pessoas desempenham suas atividades de trabalho também influenciaram o nível de uso da bicicleta. Empregados da construção civil estavam mais propensos a usar bicicleta do que aqueles inseridos na indústria ou nos serviços.

No caso do setor industrial, as viagens urbanas concentram-se basicamente na cidade de Cubatão-SP, localizada fora do eixo horizontal das demais cidades da RMBS e sem a presença de ligação, com as demais cidades, de infraestrutura de apoio ao ciclista. Vale ressaltar que as viagens de todas as zonas de tráfego da Região Metropolitana da Baixada Santista foram consideradas no estudo, porém, essas viagens deveriam ser originadas ou destinadas às cidades de Guarujá-SP, Santos-SP e São Vicente-SP.

Aliado a isto e válido também para o setor de serviços, podem ser somados a falta de bicicletário próximo ao destino final da viagem e de vestiários para que os usuários possam realizar higiene pessoal e troca de vestimenta antes de trabalhar. Salienta-se que a ação de pedalar por distâncias maiores, muitas vezes, requer roupa adequada e que pode não combinar com a atividade profissional exercida. Diferentemente do que possa estar ocorrendo com os setores industrial e de serviços, as obras civis, tanto de pequeno porte como grande porte, 
disponibilizam vestiário aos operários e há quase sempre espaço para guardar as respectivas bicicletas.

É possível também que as indústrias disponibilizem transporte fretado por ônibus e/ou vans para realizar a locomoção ao trabalho dos funcionários a partir das suas residências, contribuindo assim, para a diminuição de uso dos outros modos de transporte.

Foi possível constatar que a variável número de bicicletas no domicílio, além de influenciar positivamente na Equação (18), também apresentou valores superiores para indivíduos pertencentes ao setor construção civil e com idade entre 12 e 50 anos, conforme mostram as Tabelas 4.13 e 6.3. Salienta-se que, apesar disso, o modelo não apresentou correlação entre as variáveis presentes na função utilidade do modo bicicleta.

Em aproximadamente $60 \%$ das viagens do banco de dados da $\mathrm{O} / \mathrm{D}$, o indicador de infraestrutura cicloviária foi representado pela maior distância percorrida em ciclovia e/ou ciclofaixa pela distância total. Isto quer dizer que, na maioria das vezes, é melhor se deslocar até a infraestrutura de apoio mais próxima para que a viagem seja feita mais rapidamente. Estudos de Aultman- Hall e Hall (1998) e Tilahun et al. (2007), indicaram que ciclistas percorrem grandes distâncias, gastando até acima de 20 minutos, entre o tráfego em geral, para que possam utilizar as facilidades ao transporte cicloviário.

Através da aplicação da Árvore de Decisão e Classificação, foi verificado que o número de bicicletas no domicílio modifica-se em função do indicador de infraestrutura cicloviária que, por sua vez, também variou no período compreendido entre a contagem volumétrica de ciclistas registrado no PCM e o início das entrevistas da O/D. De posse de dados da Pesquisa Anual da Indústria da Construção Civil, publicada pelo IBGE em 2007, no Estado de São Paulo, a taxa de crescimento de empregados no setor da construção civil foi em torno de $20 \%$ entre os anos de 2006 e 2007.

Desta forma, levando em conta que a previsão foi feita no sentido inverso, ou seja, retrocedendo os valores das variáveis relacionadas à posse de bicicletas no domicílio, indicador de infraestrutura cicloviária, e número de empregados na construção civil, a 
demanda cicloviária foi estimada através do modelo de escolha discreta e comparada, em alguns pontos, com a contagem real de ciclistas registrada no PCM.

$\mathrm{O}$ fato de a contagem real de ciclistas, exceto em 2 casos, ter sido feita em intervalos de 10 minutos e, posteriormente, ter sido expandida para hora a fim de facilitar a comparação com as viagens expandidas da $\mathrm{O} / \mathrm{D}$, pode ter gerado distorções no resultado visto que é normal que haja, dentro de uma hora, variação no fluxo de ciclistas.

Além disso, em alguns casos, o ponto de contagem estava localizado em apenas uma das rotas alternativas existentes entre pares $\mathrm{O} / \mathrm{D}$, causando assim, subcontagem no fluxo de bicicletas. Desta forma, o resultado do modelo de escolha discreta foi sistematicamente maior do que a contagem volumétrica de ciclistas nesses casos, pois a demanda estava possivelmente dividida entre a via que recebeu a infraestrutura cicloviária e as vias adjacentes.

Através da análise conjunta dos pontos analisados como, por exemplo, Ciclofaixa 6, 9 e Ciclovia 10, foi possível identificar o corredor cicloviário construído para ligar o centro da cidade de Guarujá-SP com o distrito de Vicente de Carvalho. O corredor foi construído na via com acesso mais retilíneo ao distrito e, como não havia concorrência de vias paralelas, o modelo estimou adequadamente a demanda cicloviária, já que a diferença máxima percentual entre as previsões foi de $-8,12 \%$.

Foi possível identificar também alguns dos deslocamentos urbanos, como por exemplo, o existente entre a cidade de Guarujá-SP com a cidade de Cubatão-SP. Na ligação, não há trechos de ciclovias e/ou ciclofaixas e como é comumente feita por industriários que trabalham em Cubatão-SP e residem em Guarujá-SP, pode-se afirmar que a demanda cicloviária foi reprimida pois, tanto a atividade industrial como o menor indicador de infraestrutura cicloviária, contribuem negativamente na função utilidade do modo bicicleta.

Através das viagens de bicicleta selecionadas da O/D nos pontos de contagem, percebe-se que a integração cicloviária e o relevo plano existente na RMBS resulta em distâncias totais percorridas acima dos valores encontrados na literatura sobre o assunto. Além disso, foi possível perceber que ciclovias/ciclofaixas atendem, na maioria dos casos, ciclistas que viajam de um município para outro (pontos Ciclovia 1,2, 3 e 4, e Ciclofaixa 7 e 8). 
Analisando a influência dos parâmetros estimados de cada uma das três variáveis modificadas, ou seja, indicador de infraestrutura cicloviária (IND), número de bicicletas no domicílio (NBIC) e indivíduo pertencente à classe de empregados da construção civil (AT2), é possível perceber que a variável AT2 têm papel mais significativo na estimação da demanda de ciclistas, seguido da variável NBIC e, posteriormente, da variável IND.

Vale salientar que a presença de infraestrutura cicloviária pode afetar a utilidade do modo cicloviário diretamente, através do indicador de infraestrutura cicloviária, e de uma forma indireta sobre o tempo de viagem, uma vez que a velocidade na ciclovia e/ou ciclofaixa é maior do que fora dela. Portanto, apesar do indicador de infraestrutura cicloviária ter apresentado valor do parâmetro relativamente pequeno, a sua influência é maior pois afeta o tempo de viagem.

Desta forma, a hipótese do trabalho de que é possível identificar e quantificar fatores como a presença de infraestrutura cicloviária, o setor de atividade em que o indivíduo está inserido no mercado de trabalho, o sexo, a idade e a posse de bicicletas que influem na escolha do modo cicloviário foi testada e verificada como válida.

Com relação à hipótese de que o modelo estimado, com o uso dos fatores identificados e quantificados na hipótese anterior, poderá servir como instrumento de avaliação e planejamento da implantação de infraestrutura de apoio ao ciclista, foi considerada como válida visto que, exceto para casos justificáveis, o modelo previu adequadamente a demanda cicloviária através da comparação realizada nos Cenários 1 e 2. 


\section{CAPÍTULO 7}

\section{CONCLUSÕES E SUGESTÕES PARA TRABALHOS FUTUROS}

\subsection{Breve Exposição da Tese de Doutorado}

A presente Tese de Doutorado integra a linha de pesquisa desenvolvida no Departamento de Engenharia de Transportes da EESC/USP sob orientação do Professor Titular Eiji Kawamoto acerca dos fatores que influenciam o comportamento individual verificado em padrões de viagens urbanas.

A meta desta Tese foi verificar as hipóteses de que é possível identificar e quantificar os fatores que influem no uso de bicicletas e de que estes fatores podem ser usados para avaliar e planejar a implantação de cicloviais e/ou ciclofaixas em uma área urbana.

Além disso, foram propostos alguns objetivos específicos que integram o método e foram importantes para que a meta fosse atingida:

(i) Definir como área de estudo o local que dispõe de infraestrutura cicloviária para uso da população e de um conjunto de dados individuais com informações 
socioeconômicas e de viagens urbanas que contenha considerável percentual de viajantes urbanos que utilizam a bicicleta como modo de transporte;

(ii) Construir um indicador que represente a infraestrutura cicloviária implantada na área a ser estudada;

(iii) Construir variáveis acerca das informações socioeconômicas e de viagens urbanas individuais;

(iv) Propor a técnica que utilizará as variáveis construídas em (ii) e (iii) e representar quantativamente a escolha do modo cicloviário pelos viajantes urbanos;

(v) Comparar o resultado da técnica utilizada para quantificar o uso do modo cicloviário (número de viagens de bicicleta) com contagens volumétricas, existentes em pontos preestabelecidos, antes e após à implantação da infraestrutura cicloviária;

(vi) Avaliar se a técnica permite representar adequadamente os cenários que representam as situações atual e anterior à implantação da infraestrutura cicloviária.

Nas próximas subseções serão apresentadas as conclusões do segundo até o sexto capítulo da Tese ora desenvolvida.

\subsubsection{Revisão da literatura}

\begin{tabular}{|c|c|c|c|c|}
\hline $\begin{array}{c}\text { Revisão da } \\
\text { literatura }\end{array}$ & $\begin{array}{c}\text { Detalhamento do } \\
\text { método }\end{array}$ & $\begin{array}{c}\text { Preparação do } \\
\text { experimento }\end{array}$ & Experimento & $\begin{array}{c}\text { Análise e discussão } \\
\text { de resultados }\end{array}$ \\
\hline
\end{tabular}

O capítulo de revisão da literatura foi dividido em 3 seções: (i) Fatores que influenciam a demanda cicloviária - no qual foram revisados trabalhos que identificaram alguns fatores que influenciaram o uso da bicicleta em áreas urbanas; (ii) Exemplos de infraestrutura cicloviária existentes - foram apresentados alguns tipos de infraestrutura cicloviária existentes e, principalmente, destacados os tipos considerados nesta Tese que foram as ciclovias e/ou ciclofaixas implantadas na RMBS; e (iii) A estimativa da demanda cicloviária em áreas urbanas - além dos métodos usados para estimar a demanda cicloviária, foram citadas algumas experiências pertinentes à Tese na literatura existente. 
De uma maneira geral, foram citadas variáveis que eram comuns a todos os trabalhos acerca dos fatores que influenciam o uso da bicicleta. No entanto, não há estudos com o uso de modelos que servem para estimar a demanda cicloviária considerando variáveis que representam situações antes e após à implantação de infraestrutura cicloviária (no caso da Tese ora desenvolvida foram 3: o indicador de infraestrutura cicloviária, a posse de bicicletas e o número de empregados pertencentes à construção civil).

\subsubsection{Detalhamento do método}

\begin{tabular}{|c|c|c|c|c|}
\hline $\begin{array}{c}\text { Revisão da } \\
\text { literatura }\end{array}$ & $\begin{array}{c}\text { Detalhamento do } \\
\text { método }\end{array}$ & $\begin{array}{c}\text { Preparação do } \\
\text { experimento }\end{array}$ & Experimento & $\begin{array}{c}\text { Análise e discussão } \\
\text { de resultados }\end{array}$ \\
\hline
\end{tabular}

O capítulo 3 descreveu o detalhamento do método elaborado nesta Tese. Para isso, foi dividido nos seguintes tópicos: (i) Dados disponíveis; (ii) Caracterização socioeconômica, de viagens urbanas e da infraestrutura cicloviária; (iii) Estimação de um modelo de escolha discreta; (iv) Construção dos cenários 1 e 2.

Cada tópico do detalhamento do método procurou atender aos objetivos específicos citados anteriormente. Vale salientar que os órgãos responsáveis pelo planejamento de transportes não efetuaram a contagem volumétrica após a implantação das ciclovias e/ou ciclofaixas na área em análise e, por esse motivo, foi utilizada a Pesquisa O/D, realizada após a implantação da infraestrutura cicloviária, de onde foram selecionadas viagens de bicicleta que passavam pelos pontos de contagem volumétrica preestabelecidos. Estes valores serviram para a construção do cenário 1 .

Os cenários 1 e 2 foram construídos em termos de variáveis utilizadas para caracterizar as situações socioeconômicas, de viagens urbanas e da infraestrutura cicloviária; da técnica a ser utilizada (modelo de escolha discreta); e por meio da comparação entre o resultado da estimativa da demanda cicloviária através do modelo de escolha discreta e dos fluxos de ciclistas em pontos preestabelecidos, obtidos através da Pesquisa O/D e do PCM, que poderiam refutar ou não as hipóteses desta Tese. 


\subsubsection{Preparação do experimento e Experimento}

\begin{tabular}{|c|c|c|c|c|}
\hline $\begin{array}{c}\text { Revisão da } \\
\text { literatura }\end{array}$ & $\begin{array}{c}\text { Detalhamento do } \\
\text { método }\end{array}$ & $\begin{array}{c}\text { Preparação do } \\
\text { experimento }\end{array}$ & Experimento & $\begin{array}{c}\text { Análise e discussão } \\
\text { de resultados }\end{array}$ \\
\hline
\end{tabular}

Este sub-item aborda as conclusões referentes à preparação do experimento e ao experimento propriamente dito.

Foram apresentados detalhadamente os dados da RMBS disponíveis (Pesquisa O/D e PCM) para a realização do experimento. Através das tabelas 4.5 e 4.6 mostradas na preparação do experimento foi possível perceber o considerável percentual de uso da bicicleta na RMBS (aproximadamente $13,50 \%$ do total de viagens) e o público que a utiliza (baixa renda, entre 0 e $\mathrm{R} \$ 1.600,00)$. Também foram apresentados os locais de implantação de ciclovias e/ou ciclofaixas entre o término das contagens volumétricas do PCM e o início das entrevistas domiciliares da Pesquisa O/D e o resultado, tanto em termos de tamanho quanto de número, nas zonas de tráfego após eliminação de áreas verdes que não dispunham de qualquer tipo de construção.

Acredita-se que a eliminação das áreas verdes nas zonas de tráfego tenha resultado em distâncias de viagem mais próximas da realidade já que, a maioria das viagens, devem ser originadas e destinadas aos núcleos com presença de vias de acesso e construções diversas.

As caracterizações, ou codificações, para cada variável utilizada nesta Tese também foram detalhadas. A Tabela 4.16 ilustra as caracterizações feitas para as informações socioeconômicas. Em relação às características das viagens urbanas, foram considerados o custo monetário das viagens pelo modo público e privado; gratuidade e uso do vale transportes; tempo de viagem; e distância de viagem.

Por ser uma região metropolitana, o custo do modo público levou em conta as diferentes tarifas adotadas em viagens intra e intermunicipais e que o custo pelo modo privado utilizou a formulação adaptada proposta por Kawamoto e Setti (1992). As características longilíneas da RMBS, limitada pela Serra do Mar e pelo Oceano Atlântico, podem ter influenciado as distâncias de viagem e, consequentemente, os tempos de viagem da RMBS. Ressalta-se que para o modo público, além do tempo de viagem reportado e de caminhada 
informados pelo viajante urbano na $\mathrm{O} / \mathrm{D}$, foi considerado o tempo de espera médio calculado a partir de informações de frequência de linhas intra e intermunicipal de transporte coletivo.

Já a caracterização da infraestrutura cicloviária, elaborado a partir da relação entre distâncias percorridas em infraestrutura cicloviária e distâncias percorridas totais, considerou que trechos percorridos em ciclovias e/ou ciclofaixas são feitos em velocidade superior aos trechos percorridos junto ao tráfego de veículos motorizados $(16,02 \mathrm{~km} / \mathrm{h}$ contra $7,50 \mathrm{~km} / \mathrm{h}$, respectivamente). Considerou-se que o ciclista sempre prefere a rota com menor tempo de viagem entre os centróides de origem e destino das zonas de tráfego.

A partir das caracterizações foi possível realizar o experimento da Tese que consistiu de estimação do modelo de escolha discreta e a construção dos cenários 1 e 2 .

A estimação do modelo de escolha discreta considerou 4 alternativas de modo de viagem: privado; público; bicicleta; e a pé. Os resultados dos parâmetros das funções utilidade para cada modo considerado foram mostrados na Tabela 5.1.

De posse da estimação do modelo de escolha discreta e dos 11 pontos preestabelecidos de contagem volumétrica localizados nas cidades de Guarujá-SP, Santos-SP e São Vicente-SP foi possível a construção, inicialmente, do Cenário 1. Salienta-se que nestes pontos foram construídas ciclovias ou ciclofaixas biderecionais e, por questões de representatividade estatística, o experimento considerou a soma da demanda cicloviária existente nos dois sentidos, pois o volume de contagem em cada sentido, no intervalo de 10 minutos, é relativamente baixo em alguns casos.

O Cenário 1, no qual foi reproduzido a situação atual (após implantação das ciclovias e/ou ciclofaixas), a diferença máxima notada entre a estimação da demanda cicloviária através do modelo de escolha discreta e as viagens de bicicleta selecionadas da $\mathrm{O} / \mathrm{D}$, que passavam pelos pontos, foi de $-30,15 \%$ a menos na demanda calculada com o uso do modelo. Já a comparação entre as somatórias da demanda cicloviária pelas duas formas (modelo e viagens selecionadas), considerando todos os pontos, foi de apenas 1,88\%. Provavelmente o resultado do Cenário 1 foi influenciado pelas diferenças causadas pelo pequeno número de viagens de 
bicicleta contido na Pesquisa O/D utilizada (número variando entre 10 e 28 viagens segundo a coluna 4 da Tabela 5.4) e pela aleatoriedade a que qualquer Pesquisa O/D está sujeita.

O ideal seria que houvesse a contagem real de ciclistas nos pontos preestabelecidos após a implantação da infraestrutura cicloviária, entretanto, estes dados não estavam disponíveis e, portanto, a O/D teve que ser utilizada. Apesar disso, como as diferenças em 4 dos 11 pontos analisados foi inferior à $4 \%$, em 5 dos 11 pontos foi entre 10 e $20 \%$ e em 2 pontos foi $28,19 \%$ e $-30,15 \%$, considerou-se que o modelo reproduziu adequadamente o número de viagens de bicicleta para a situação prevista para o cenário 1 .

No detalhamento do método foi previsto que, caso o modelo reproduza adequadamente o número de viagens de bicicleta no cenário 1, seria construído o cenário 2 . Neste cenário foram modificadas os valores das variáveis da função utilidade da bicicleta que, por ventura, tenham sofrido modificações consideráveis entre o término das contagens volumétricas do PCM e o início das entrevistas domiciliares da Pesquisa O/D.

Segundo o IBGE (2007), a construção civil no Estado de São Paulo apresentou um acréscimo de aproximadamente $20 \%$ no número de pessoas empregadas entre os anos de 2006 e 2007. Assim, para 2006, o fator de expansão dos indivíduos pertencentes ao setor de atividade da construção civil (variável AT2 igual a 1 no banco de dados) teve que sofrer um decréscimo de $20 \%$ para representar o número de pessoas empregadas no ano.

O número de bicicletas no domicílio foi outra variável que apresentou variação no período. Com o auxílio da árvore de decisão e classificação, concluiu-se que o número médio de bicicletas no domicílio cresceu com o aumento do indicador de infraestrutura cicloviária. Como não havia disponibilidade de ciclovias e/ou ciclofaixas este número médio era menor na situação prevista para o Cenário 2 e, desta forma, a variável foi alterada a partir dos valores mostrados na Tabela 5.6 para os indivíduos que passavam pelos pontos de contagem.

A outra variável modificada foi o indicador de infraestrutura cicloviária. As viagens contidas no banco de dados da RMBS que cruzaram os pontos de contagem tiveram o valor zero adotado para o indicador, pois antes não havia infraestrutura cicloviária disponível nestes pontos. 
O experimento foi finalizado com as comparações previstas para o cenário 2 em cada um dos 11 pontos preestabelecidos. Analisando caso a caso, concluiu-se que as diferenças notadas foram causadas, principalmente, por contagens feitas em apenas 10 minutos e que foram expandidas para hora; e também em virtude da existência de vias adjacentes que "competem" pela preferência do ciclista ao escolher o caminho entre origem e destino.

\subsubsection{Análise e discussão de resultados}

\begin{tabular}{|c|c|c|c|c|}
\hline $\begin{array}{c}\text { Revisão da } \\
\text { literatura }\end{array}$ & $\begin{array}{c}\text { Detalhamento do } \\
\text { método }\end{array}$ & $\begin{array}{c}\text { Preparação do } \\
\text { experimento }\end{array}$ & Experimento & $\begin{array}{c}\text { Análise e discussão } \\
\text { de resultados }\end{array}$ \\
\hline
\end{tabular}

O capítulo de análise e discussão de resultados foi dividido em dois tópicos: análise da especificação do modelo de escolha discreta e análise dos cenários 1 e 2.

Com relação à especificação do modelo de escolha discreta, todos os sinais dos parâmetros determinados pelo modelo foram condizentes com o esperado. As variáveis relacionadas ao tempo e ao custo de viagem foram negativas pois, reconhecidamente, quanto maior o tempo e o custo menor a probabilidade de realização de viagens por um determinado modo de transporte. Ressalta-se que para os modos não-motorizados o peso da variável tempo de viagem foi maior em relação aos modos motorizados e isto sugere que nestes modos a variável tempo sintetiza também o dispêndio de esforço físico durante a viagem.

As variáveis referentes a possuir ou não automóvel no domicílio (Ncarl), possuir ou não mais de 1 automóvel no domicílio (Ncar2) e ser chefe da família (SF1) foram positivas na função utilidade do modo privado. O peso do parâmetro da variável Ncar2 maior do que o da variável Ncarl foi condizente com o esperado, pois o fato de possuir mais de 1 automóvel no domicílio aumenta a probabilidade de uso do referido modo pelos viajantes urbanos.

Com relação ao modo público, as variáveis que dizem respeito ao vínculo empregatício (VE2 e VE3) e à renda domiciliar (RD1 e RD2) dos indivíduos foram estatisticamente significativas na função utilidade do modo em questão. Foi possível perceber que as categorias trabalhistas em que não há o recebimento do vale-transporte (tanto VE2 como VE3), juntamente com a possibilidade de não realizar muitas viagens (VE3 - categoria de empregadores, donos de negócio familiar, trabalhadores familiares ou voluntários), foram inibidores de viagens pelo modo público. Também os resultados para as classes de renda 
domiciliares baixas, consideradas na função utilidade, corroboram a hipótese de que quanto menor a renda, no caso da RMBS, maior a restrição ao uso do modo público e maior a utilização de modos não-motorizados.

Para o modo a pé, a política das Secretarias de Educação de recomendar que estudantes de escolas públicas, de ensino fundamental, sejam matriculados em escolas relativamente próximas às suas residências, pode justificar o efeito positivo na função utilidade do modo à pé da variável E4.

Já para a bicicleta, indivíduos de sexo masculino (variável sexo) e inseridos em atividades relacionadas à construção civil (variável AT2), em idade entre 12 e 50 anos (variáveis ID2 e ID7), que possuem bicicletas no domicílio (variável $N B I C$ ) e que dispõem de infraestrutura cicloviária (variável IND) entre a origem e destino estão mais propensos ao uso da bicicleta, segundo a estimação dos parâmetros das variáveis pelo modelo logit multinomial para a RMBS. Vale citar que esta estimação está de acordo com os trabalhos citados na revisão da literatura desta Tese de Doutorado.

Os sinais dos parâmetros para as atividades de indústria (variável AT3) e de serviços (variável AT5) na função utilidade do modo bicicleta foram negativos. A concentração de atividades relacionadas à indústria na cidade de Cubatão/SP que, por sua vez, não possui ligação cicloviária com as demais cidades devem estar influenciando negativamente o uso da bicicleta. Aliado a isto, podem ser somados a falta de bicicletários próximo ao destino final da viagem, tanto para a atividade de indústria como para o setor de serviços, e de vestiários para que os usuários possam tomar banho e trocar de vestimenta antes de trabalhar. Também, o fato de que as indústrias possam estar fretando o transporte por ônibus e/ou vans da residência dos funcionários até o local de trabalho e vice-versa, contribuem para o menor uso de outros modos de transporte para esta categoria de atividade econômica.

Para o setor da construção civil, quase sempre, é disponibilizado banheiros (ou vestiários, dependendo do porte da obra) para tomar banho e trocar de roupa e, além disso, há espaço interno para guardar as respectivas bicicletas.

Com relação às análises dos cenários 1 e 2 realizados, não é de se esperar que o modelo estimado represente identicamente a contagem real de ciclistas pois, como já dito, 
pode haver outras variáveis, não utilizadas neste trabalho, que poderiam diminuir a diferença percentual na previsão (por exemplo, a oferta e caracterização de postos de trabalho ou a presença de bicicletários nas zonas de tráfego). Além disso, a exclusão de viagens intrazonais, ou seja, de viagens com distâncias menores, e que, por este motivo, são mais interessantes ao uso da bicicleta, podem ter contribuído para a diferença entre os resultados.

Entretanto, salvo algumas exceções, as diferenças notadas em ambos cenários foram relativamente pequenas. Particularmente para o cenário 1, a comparação do resultado através do modelo estimado com dados de viagens de bicicleta extraídos diretamente da Pesquisa O/D foi prejudicada pelo pequeno número de viagens de bicicleta nos pontos preestabelecidos, (variou entre 10 e 28 viagens apenas). A maior diferença relativa foi de $-30,15 \%$ entre o modelo de escolha discreta e as viagens de bicicleta selecionadas da $\mathrm{O} / \mathrm{D}$, que passavam pelos pontos, o que significou o prosseguimento do método proposto através da realização do cenário 2.

As variáveis modificadas $(A T 2, N B I C$ e IND) para construção do cenário anterior (ano 2006) à implantação de ciclovias e/ou ciclofaixas na RMBS causaram o efeito desejado na previsão de demanda cicloviária através do modelo estimado de escolha discreta nos pontos de contagens volumétricas em análise. Com exceção dos pontos localizados em apenas uma das rotas alternativas existentes entre pares $\mathrm{O} / \mathrm{D}$, causando assim, subcontagem no fluxo de bicicletas, o modelo não previu adequadamente a demanda cicloviária. Nestes pontos, o resultado do modelo de escolha discreta foi sistematicamente maior do que a contagem volumétrica de ciclistas pois provavelmente o fluxo de ciclistas se distribui entre a via que recebeu a infraestrutura cicloviária e as vias adjacentes.

Também, o fato de que na maioria dos pontos a contagem ter sido feita em intervalos de 10 minutos e, posteriormente, expandida para hora afim de facilitar a comparação com as viagens expandidas da $\mathrm{O} / \mathrm{D}$, pode ter gerado distorções no resultado visto que é normal que haja, dentro de uma hora, variação no fluxo de ciclistas.

Vale ressaltar que analisando a influência dos parâmetros estimados de cada uma das três variáveis modificadas, ou seja, indicador de infraestrutura cicloviária (IND), número de bicicletas no domicílio $(N B I C)$ e indivíduo pertencente à classe de empregados da construção 
civil (AT2), é possível perceber que a variável AT2 têm papel mais significativo na estimação da demanda de ciclistas, seguido da variável NBIC e, posteriormente, da variável IND. Os valores foram 1,36, 0,537 e 0,302, respectivamente. No entanto, a infraestrutura cicloviária afeta indiretamente o tempo de viagem, pois a velocidade desenvolvida em ciclovia e/ou ciclofaixa é maior do que fora dela e, desta maneira, a influência da infraestrutura cicloviária pode ser considerada maior do que o parâmetro da variável IND.

Da análise conjunta dos pontos de contagem, foi possível perceber o corredor cicloviário construído para ligar o centro da cidade de Guarujá-SP com o distrito de Vicente de Carvalho (pontos Ciclofaixa 6, 9 e Ciclovia 10), em que a diferença máxima relativa, em porcentagem, entre a previsão pelo modelo e o resultado da contagem do PCM foi de $8,12 \%$.

Foi detectado o deslocamento urbano entre a cidade de Guarujá-SP e a cidade de Cubatão-SP. Na ligação não há trechos de ciclovias e/ou ciclofaixas e, como ela é comumente utilizada por industriários que trabalham em Cubatão-SP e residem em Guarujá-SP, pode-se afirmar que a demanda cicloviária foi reprimida pois, tanto a atividade industrial como o menor indicador de infraestrutura cicloviária, foram negativos na função utilidade do modo bicicleta.

Com relação às distâncias de viagens, percebe-se que o caráter metropolitano da área em estudo, com a presença de cidades com maior atividade econômica (Santos-SP e CubatãoSP) e outras caracterizadas como cidades-dormitório (por exemplo, Guarujá-SP, Praia Grande-SP e São Vicente-SP), resultaram em distâncias maiores percorridas pelos ciclistas em comparação com os valores encontrados na literatura. Além da disponibilidade de ciclovias e ciclofaixas entre as cidades, o relevo plano e o clima agradável, com ventilação proveniente do Oceano Atlântico, também provavelmente contribuem para aumentar as distâncias percorridas pelos ciclistas da RMBS.

\subsection{Principais Conclusões}

A ideia de propor um estudo comportamental da demanda cicloviária dentro de uma mesma área, comparando dados obtidos em períodos distintos que capturam as mudanças implantadas no sistema viário e também em variáveis socioeconômicas, foi de grande 
utilidade para o entendimento do comportamento individual da escolha do modo de viagem por parte da população da RMBS.

O método elaborado mostrou-se viável a partir dos dados disponíveis para a RMBS. Tanto a Pesquisa O/D feita a partir do ano de 2007, que dispunha de deslocamentos feitos de bicicleta correspondentes a aproximadamente $15 \%$ de todos os deslocamentos, quanto o PCM feito em 2006, que continha as contagens volumétricas em pontos conhecidos antes da implantação da infraestrutura cicloviária, permitiram a construção de cenários que representaram a demanda cicloviária existentes nos respectivos anos.

A partir da análise de resultados dos cenários 1 e 2 construídos, destacou-se a adequada estimação da demanda cicloviária em pontos preestabelecidos através do modelo de escolha discreta envolvendo variáveis socioeconômicas, de viagens urbanas e de um indicador que representava a infraestrutura cicloviária na RMBS.

Em termos práticos, o procedimento adotado na Tese ora desenvolvida pode ser considerado simples e relativamente fácil de ser aplicado em áreas urbanas. Além das contagens volumétricas antes e depois da implantação de infraestrutura cicloviária, seria necessário levantar as informações socioeconômicas e de viagens urbanas na área de influência das ciclovias e/ou ciclofaixas a serem implantadas. Após estimar um modelo de escolha discreta com essas informações, o passo seguinte seria comparar o resultado através do modelo com os fluxos de ciclistas determinados pela contagem.

Desta forma, de uma maneira geral, a meta e os objetivos específicos propostos nesta Tese foram atingidos e, portanto, as hipóteses formuladas não podem ser refutadas visto que foram identificados e quantificados os fatores que influem no uso da bicicleta na RMBS e de que estes fatores podem ser usados para avaliar e planejar a implantação de ciclovias e/ou ciclofaixas em áreas urbanas.

\subsection{Sugestões para Trabalhos Futuros}

Estudos que envolvem os transportes não-motorizados, em especial à bicicleta, ainda são escassos na literatura existente sobre planejamento de transportes. Pretende-se listar aqui apenas alguns pontos que podem servir de base para futuras pesquisas: 
- Analisar a influência da variável que representa o relevo da área urbana na escolha do modo cicloviário;

- Incluir indicadores de infraestrutura cicloviária que representem a quantidade de bicicletários, quantidade de vestiários e o número de oficinas para bicicletas por zona de tráfego;

- Obter dados específicos para calibração do modelo logit multinomial;

- Aplicar o modelo de escolha discreta estimado com os dados da RMBS em outra área urbana;

- Analisar se as medidas de largura, total e efetiva, de ciclovias e/ou ciclofaixas e a presença de fluxo considerável de veículos motorizados podem influenciar no maior ou menor uso da bicicleta;

- Incluir a análise da influência do número de postos de trabalho e os respectivos tipos de trabalho por zona de tráfego na escolha do modo cicloviário;

- Incluir estudos da área da saúde como, por exemplo, capacidade física em função da idade aos trabalhos que envolvem o uso do modo cicloviário;

- Identificar prefeituras municipais que planejam construir ciclovias e/ou ciclofaixas e realizar contagens antes e depois em pontos não só na via em que se pretende implantar a infraestrutura cicloviária, mas em todas as vias adjacentes que podem servir de rota; e

- Utilizar o modelo de escolha modal como subsídio na formulação de Planos Diretores e de mobilidade nas cidades da Região Metropolitana da Baixada Santista. 


\section{REFERENCIAS BIBLIOGRÁFICAS}

4

AGUIAR, M. F. M. (2005). Possibilidade de redução no tamanho da amostra de pesquisas de entrevistas domiciliares para planejamento de entrevistas domiciliares para planejamento de transportes, 180f. Dissertação (Mestrado) - Escola de Engenharia de São Carlos, Universidade de São Paulo, São Carlos - SP, Brasil.

AKAR, G.; CLIFTON, K. J. (2009). The Influence of Individual Perceptions and Bicycle Infrastructure on the Decision to Bike. Transportation Research Record: Journal of the Transportation Board, $\mathbf{n}^{\circ}$. 2140. Washington, DC.

AN, M.; CHEN, M. (2007). Estimating Nonmotorized Travel Demand. Transportation Research Record: Journal of the Transportation Board, $\mathbf{n}^{\circ}$. 2002. Washington, DC.

AQUINO, A. P. P. (2007). Análise das Potencialidades da Integração entre Trem e Bicicleta e da sua Viabilidade em um Aglomerado Urbano Brasileiro, 158f. Dissertação (Mestrado) - Universidade Federal da Paraíba, João Pessoa - PB, Brasil.

ASHLEY, C. A.; BANISTER, C. (1989). Cycling to Work from Wards in a Metropolitan Area: Factors Influencing Cycling to Work. Traffic Engineering \& Control, vol. 30, nº 6, pp. 297-302. 
AULTMAN-HALL, L.; HALL, F. (1998). Research Design Insights from a Survey of Urban Bicycle Commuters. Transportation Research Record: Journal of the Transportation Board, $\mathbf{n}^{\circ}$. 1636. Washington, DC.

AXHAUSEN, K. W.; SMITH, R. L. (1986). Bicyclist Link Evaluation: a Stated-preference Approach. Transportation Research Record: Journal of the Transportation Board, $\mathbf{n}^{\mathbf{0}}$. 1085. Washington, DC.

BARNES, G.; KRIZEK, K. (2005). Estimating Bicycling Demand. Transportation Research Record: Journal of the Transportation Board, $\mathbf{n}^{\circ}$. 1939. Washington, DC.

BEN-AKIVA, M.; ATHERTON, T. J. (1977). Methodology for Short-range Travel Demand Predictions. Journal of Transport Economics and Policy, vol. 13, no. 3, pp. 224-261.

BEN-AKIVA, M.; LERMAN, S. (1985). Discrete choice analysis: theory and aplication to travel demand. 2a . Edição, 390p. Cambridge: The MIT Press.

BIERLAIRE, M. (2009). Estimation of discrete choice models with BIOGEME 1.8. 111f. Manual - Ècole Polytechnique Féderale de Lausanne.

BOVY, P. H. L.; BRADLEY, M. A. (2004). Route Choice Analyzed with Stated-preference Approaches. Transportation Research Record: Journal of the Transportation Board, $\mathbf{n}^{\mathbf{0}}$. 1037. Washington, DC.

BUEHLER, R.; PUCHER, J. (2011). Impacts of Bike Path and Lanes on Cycling in Large American Cities. Transportation Research Board, CD-ROM 90 ${ }^{\text {th }}$ Annual Meeting, Washington, D.C.

BRASIL (1997) Lei nº 9.503, de 23 de setembro de 1997. Institui o CTB - Código de Trânsito Brasileiro. Diário Oficial da União, Brasília, DF, 24 de setembro de 1997. 
COSTA, M. S. (2003). Mobilidade urbana sustentável: um estudo comparativo e as bases para de um sistema de gestão para Brasil e Portugal, 184f. Dissertação (Mestrado) Escola de Engenharia de São Carlos, Universidade de São Paulo, São Carlos - SP, Brasil.

CPTM (2008). Projeto Pedalada - Programa de Incentivo ao Uso da Bicicleta no Acesso à Rede da CPTM através da Implantação de Bicicletários em suas Estações, 21f. Companhia Paulista de Trens Metropolitanos, 2008. São Paulo-SP, Brasil.

DAVIS, G.; WICKLATZ, T. (2001). Sample-based estimation of bicycle miles of travel (BMT). MN/DOT 2001-23, Minnesota Department of Transportation, 2001.

DEPARTAMENTO INTERSINDICAL DE ESTATÍSTICA E ESTUDOS SOCIOECONÔMICOS - DIEESE (2011). ESTUDO SETORIAL DA CONSTRUÇÃO. Estudos e Pesquisas, nº. 56, 31f. São Paulo-SP, Brasil.

DILL, J.; CARR, T. (2003). Bicycle Commuting and Facilities in Major U.S. Cities: If You Build Them, Commuters Will Use Them. Transportation Research Board, CD-ROM $82^{\text {th }}$ Annual Meeting, Washington, D.C.

DUTRA, C. B. (2007). Pesquisa sobre Transporte Não-Motorizado Realizado por Bicicleta na Cidade de Londrina. Em: $\mathbf{1 6}^{\circ}$ Congresso Brasileiro de Transporte e Trânsito - ANTP, 2007, Maceió-AL, Brasil. 1 CD-ROM.

EUROPEAN ENVIROMENT AGENCY - EEA (1999). ENVIRONMENTAL INDICATORS: TYPOLOGY AND OVERVIEW. EEA, Copenhague.

EPPERSON, B.; HENDRICKS, S. J.; YORK, M. (1995). Estimation of Bicycle Transportation Demand from Limited Data. Em: Compendium of Technical Papers from the Institute of Transportation Engineers 65 $^{\text {th }}$ Annual Meeting, 1995, pp. 436-440.

FORESTER, J. (1986). Effective Cycling. Em: MIT PRESS, 1986, Cambridge, Massachussets. 
FEDERAL HIGHWAY ADMINISTRATION - FHWA (2003). FHWA's COURSE ON BICYCLE \& PEDESTRIAN TRANSPORTATION. U.S. Department Of Transportation, 2003.

GATERSLEBEN, B.; HADDAD, H. (2010). Who is the Typical Bicyclist? Transportation Research Part F 13, pp. 41-48.

GEIPOT (2001). Manual de Planejamento Cicloviário, 126f. Empresa Brasileira de Planejamento de Transportes - GEIPOT, $3^{\text {a }}$. Edição revisada e ampliada. Brasília-DF, Brasil.

HOPKINSON, P.; WARDMAN, M. (1996). Evaluation of the Demand for New Cycling Facilities. Em: Transport Policy, vol. 3, no. 4, pp. 241-249.

HOROWITZ, Z.; PARISI, D.; REPLING, J. (2010). Forecasting Pedestrian and Bicycle Demands Using Regional Travel Demand Models and Local Mode Share/Trip Distance Data. Transportation Research Board, CD-ROM $89^{\text {th }}$ Annual Meeting, Washington, D.C.

HUNT, J. D.; ABRAHAM, J. E. (2007). Influences on Bicycle Use. Em: Transportation, no. 34, $p p$ 453-470.

INSTITUTO BRASILEIRO DE GEOGRAFIA E ESTATÍSTICA - IBGE (2000). CENSO 2000. Informações sobre o recenseamento da população da Região Metropolitana da Baixada Santista no ano de 2000. Rio de Janeiro-RJ, Brasil.

INSTITUTO BRASILEIRO DE GEOGRAFIA E ESTATÍSTICA - IBGE (2010). CENSO 2010. Informações sobre o recenseamento da população da Região Metropolitana da Baixada Santista no ano de 2010. Rio de Janeiro-RJ, Brasil.

INSTITUTO BRASILEIRO DE GEOGRAFIA E ESTATÍSTICA - IBGE (2007). PESQUISA ANUAL DA INDÚSTRIA DA CONSTRUÇÃO. IBGE, vol. 17, pp. 1 - 84. Rio de Janeiro-RJ, Brasil. 
ICHIKAWA, S. M. (2002). Aplicação de minerador de dados na obtenção de relações entre padrões de encadeamento de viagens codificados e características socioeconômicas, 136f. Dissertação (Mestrado) - Escola de Engenharia de São Carlos, Universidade de São Paulo, São Carlos-SP, Brasil.

KATZ, R. (1995). Modelling Bicycle Demand as a Mainstream Transportation Planning Function. Transportation Research Board 1502, pp. 22-28. Washington, D.C.

KAWAMOTO, E.; SETTI, J. R. (1992). Procedure for the Calibration of a Semicompensatory Mode Choice Model. Transportation Research Record: Journal of the Transportation Board, $\mathbf{n}^{\mathbf{0}}$. 1357. Washington, DC.

KEMPERMAN, A.; TIMMERMANS, H. (2009). Influences of built environment on walking and cycling by latent segments of aging population. Transportation Research Record: Journal of the Transportation Board, $\mathbf{n}^{\circ} .2134$. Washington, DC.

KIRNER, J. (2006). Proposta de um Método para a Definição de Rotas Cicláveis em Áreas Urbanas, 119f. Dissertação (Mestrado) - Universidade Federal de São Carlos, São Carlos-SP, Brasil.

KRIZEK, K. J.; JOHNSON, P. J.; TILAHUN, N. (2004). Gender Differences in Bicycling Behavior and Facility Preferences. Em: Conference on Research on Women's Issues in Transportation, 2004, Chicago, Illinois, EUA.

LANDIS, B.; TOOLE, J. (1996). Using the Latent Demand Score Model to Estimate Use. Em: Pro Bike Pro Walk 96: Forecasting the Future, 2007. Bicycle Federation of America/Pedestrian Federation of America, pp. 320-325.

LOTT, D. Y.; TARDIFF, T.; LOTT, D. F. (1977). Bicycle Transportation for Downtown Work Trips: A Case Study in Davis, California. Transportation Research Record: Journal of the Transportation Board, $\mathbf{n}^{\mathbf{0}}$. 629. Washington, DC. 
MAGAlhãeS, M. T. Q. (2004). Metodologia para Desenvolvimento de Sistemas de Indicadores: Uma Aplicação no Planejamento e Gestão da Política Nacional de Transportes, 135f. Dissertação (Mestrado) - Universidade de Brasília, Brasília-DF, Brasil.

MAIA, C. A.; MOREIRA, M. E. P. (2010). Caracterização dos Deslocamentos de Ciclistas e Fatores que Influenciam suas Viagens em Fortaleza-CE. Em: XXIV ANPET - Congresso de Pesquisa e Ensino em Transportes, 2010, Salvador-BA, Brasil. 1 CD-ROM.

MANESS, M. (2012). Bicycle Ownership in the United States: Empirical Analysis of Regional Differences. Transportation Research Board, CD-ROM $91^{\text {th }}$ Annual Meeting, Washington, D.C.

MOUdON, A. V.; LEE, C.; CHEADlE, A. D.; COLlIER, C. W.; JOHNSON, D.; SCHMIDT, T. L.; WEATHER, R. D. (2005). Cycling and the Built Enviroment, A U. S. Perspective. Transportation Research Part D 11, pp. 245-261.

NELSON, A. C.; ALLEN, D. (1997). If you build them, commuters will use them: Association between bicycle facilities and bicycle commuting. Transportation Research Record: Journal of the Transportation Board, $\mathbf{n}^{0}$. 1578. Washington, DC.

ORGANIZATION FOR ECONOMIC CO-OPERATION AND DEVELOPMENT - OECD (2002). OECD FRAMEWORK FOR ENVIRONMENTAL INDICATORS. OECD, Paris.

ORTÚZAR, J. D.; IACOBELLI, I.; VALEZE, C. (2000). Estimating demand for a cycle-way network. Transportation Research Part A 34, pp. 353-373.

PCM (2006). Estudos técnicos, levantamentos, diagnóstico e diretrizes para elaboração do Plano Cicloviário Metropolitano (PCM) da Região Metropolitana da Baixada Santista, 349f. Agência Metropolitana da Baixada Santista - AGEM. Santos-SP, Brasil.

PEZZUTO, C. C. (2002). Fatores que influenciam o uso da bicicleta, 146f. Dissertação (Mestrado) - Universidade Federal de São Carlos, São Carlos-SP, Brasil. 
PITOMBO, C. S. (2003). Análise do comportamento subjacente ao encadeamento de viagens através do uso de minerador de dados, 148f. Dissertação (Mestrado) - Escola de Engenharia de São Carlos, Universidade de São Paulo, São Carlos - SP, 2003.

PITOMBO, C. S. (2007). Estudos de relações entre variáveis socioeconômicas, de uso do solo, participação em atividades e padrões de viagens encadeadas urbanas, 268f. Tese (Doutorado) - Escola de Engenharia de São Carlos, Universidade de São Paulo, São Carlos SP, Brasil.

PLAUT, P. O. (2005). Non-motorized Commuting in the U. S. Transportation Research Part D 10, pp. 347-356.

PORTER, C.; SUHRBIER, J.; SCHWARTZ, W. L. (1999). Forecasting bicycle and pedestrian travel: State of the practice and research needs. Transportation Research Record: Journal of the Transportation Board, $\mathbf{n}^{0}$. 1674. Washington, DC.

PORTUGal, L. S.; GOLDNER, L. G. (2003). Estudos de Pólos Geradores de Tráfego e de seus Impactos nos Sistemas Viários e de Transportes. 1ª Edição, 322p. Ed.: EDGARD BLÜCHER LTDA, São Paulo-SP, Brasil.

PUCHER, J.; BUEHLER, R. (2008). Cycling for Everyone: Lessons from Europe. Transportation Research Board, CD-ROM $87^{\text {th }}$ Annual Meeting, Washington, D.C.

PUCHER, J.; KOMANOFF, C.; SCHIMEK, P. (1999). Bicycle Renaissance in North America? Recent Trends and Alternative Policies to Promote Cycling. Transportation Research Part A 33, pp. 625-654.

RIETVELD, P.; DANIEL, V. (2004). Determinants of bicycle use: do municipal policies matter? Transportation Research Part A 38, pp. 353-373.

RIETVELD, P.; KOETSE, M. (2003). Crime and offences in transport. Em: Progress in Transportation Research - Jourquin, B.; Polak, J. (Eds.), 2003, De Boeck, Antuérpia, Bélgica, pp. 123-142. 
RYLEY, T. (2006). Estimating cycling demand for the journey to work or study in West Edinburgh, Scotland. Transportation Research Record: Journal of the Transportation Board, $\mathbf{n}^{0}$. 1982. Washington, DC.

SILVA, M. A. (2006). Verificação da aplicabilidade da técnica de mineração de dados na previsão da demanda por transporte de passageiros urbanos usando dados da Região Metropolitana de São Paulo, 176f. Dissertação (Mestrado) - Escola de Engenharia de São Carlos, Universidade de São Paulo, São Carlos - SP, Brasil.

SILVA, M. A. (2011). Estudo da incorporação da acessibilidade à atividade na análise da demanda por viagens encadeadas, 262f. Tese (Doutorado) - Escola de Engenharia de São Carlos, Universidade de São Paulo, São Carlos - SP, Brasil.

SORTON, A.; WALSH, T. (1994). Bicycle Stress Level as a Tool to evaluate Urban and Suburban Bicycle Compatibility. Transportation Research Record: Journal of the Transportation Board, $\mathbf{n}^{\circ}$. 1438. Washington, DC.

SOUSA, P. B. (2004). Análise comparativa do encadeamento de viagens de três urbanas. 130f. Dissertação (Mestrado) - Escola de Engenharia de São Carlos, Universidade de São Paulo, São Carlos - SP, 2004.

STINSON, M.; BHAT, C. R. (2003). Analysis of Commuter Bicyclist Route Choice Using a Stated Preference Survey. Transportation Research Board, CD-ROM $82^{\text {th }}$ Annual Meeting, Washington, D.C.

STM (2007). Relatório Técnico - Pesquisa Origem-Destino 2007: Região Metropolitana da Baixada Santista, 110f. Secretaria dos Transportes Metropolitanos do Estado de São Paulo - STM/SP. São Paulo-SP, Brasil.

TACO, P. W. G. (2003). Redes Neurais Artificiais Aplicadas na Modelagem Individual de Padrões de viagens encadeadas a pé, 209f. Doutorado (Tese) - Escola de Engenharia de São Carlos, Universidade de São Paulo, São Carlos - SP, Brasil. 
TILAHUN, N.; LEVINSON, D. M.; KRIZEK, K. (2007). Trails, Lanes, or Traffic: Valuing Bycicle Facilities With an Adaptive Stated Preference Survey. Transportation Research Part A 41, pp. 287-301.

TURNER, S.; HOTTENSTEIN, A.; SHUNK, G. (1997). Bicycle and Pedestrian Travel Demand Forecasting Literature Review. Publicação nº 1723-1. Texas Transportation Institute, Texas A\&M University, and Texas Department of Transportation.

VARIAN, H. R. (1994). Microeconomia: Princípios básicos, 807f. Editora Elsevier LTDA. Rio de Janeiro-RJ, Brasil.

WARDMAN, M.; HATFIELD, R.; PAGE, M. (1997). The UK National Cycling Strategy: Can Improve Facilities Meet the Targets? Em: Transport Policy, vol. 4, no . 2, pp. 123-133.

WARDMAN, M.; TIGHT, M.; PAGE, M. (2007). Factors influencing the propensity to cycle to work. Transportation Research Part A 41, pp. 339-350. 